\author{
UNIVERSIDADE DE SÃO PAULO \\ FACULDADE DE FILOSOFIA, LETRAS E CIÊNCIAS HUMANAS \\ DEPARTAMENTO DE HISTÓRIA \\ PROGRAMA DE PÓS-GRADUAÇÃO EM HISTÓRIA SOCIAL
}

ADRIANA SALAY LEME

Feijão, dono das tradições: representação identitária e consumo efetivo no Brasil (1973-2009)

Versão Corrigida

São Paulo

2015 


\author{
UNIVERSIDADE DE SÃO PAULO \\ FACULDADE DE FILOSOFIA, LETRAS E CIÊNCIAS HUMANAS \\ DEPARTAMENTO DE HISTÓRIA \\ PROGRAMA DE PÓS-GRADUAÇÃO EM HISTÓRIA SOCIAL
}

\title{
Feijão, dono das tradições: representação identitária e consumo efetivo no Brasil (1973-2009)
}

\author{
Versão Corrigida
}

Adriana Salay Leme

\begin{abstract}
Dissertação apresentada ao
Programa de Pós-Graduação em História Social do Departamento de História da Faculdade de Filosofia, Letras e Ciências Humanas da Universidade de São Paulo, para a obtenção do título de mestre em História
\end{abstract}

Orientador: Henrique Soares Carneiro 
Para Dória, pelos novos horizontes criados.

Para Pedro e Beatriz, meu futuro. 
Dez, doze ou mais: o tempo não importa quando aperta o desejo brasileiro de ter no prato a preta, amiga vagem.

Carlos Drummond de Andrade 


\section{AGRADECIMENTOS}

Um dia me disseram que o historiador não pode ser apaixonado pelo seu objeto de estudo. Se por um lado concordo, a distância é fundamental para a análise, por outro discordo. Lidar com um tema por tanto tempo sem paixão seria inconcebível para mim. Por isso, agradeço ao professor Henrique Soares Carneiro, que me possibilitou enveredar por uma área que me fascina, a alimentação. Aos professores que participaram da minha banca de exame de Qualificação, Carlos Alberto Dória e Rodrigo Ricupero, por apontarem os caminhos possíveis para esta empreitada. Também ao professor João Paulo Garrido Pimenta, por me apresentar o mundo acadêmico.

Ao Centro de Cultura Culinária Câmara Cascudo, C5, por me proporcionar a oportunidade de conhecer pessoas tão especiais que compartilham, além da curiosidade, refeições inesquecíveis. Sem esse espaço tenho certeza que minha experiência pelo universo da comida não seria a mesma. Aos amigos dedicados ao estudo do tema nas suas mais variadas formas, Ivan Ralston, Marina Santos, Carolina Bastos, Patrick Assumpção, Helena Rizzo, Bruno Zucato, Rodrigo Oliveira, Joana Pellerano, Rafaela Basso, Wanessa Asfora, João Máximo, Viviana Venosa, Maria Henriqueta Gimenes Minasse, Paula Pinto e Silva, Valdely Kinupp e tantos outros.

Gostaria de agradecer à Janaina Fidalgo, amiga que gentilmente revisou a tese. E ao Paulo, muito mais que um grande amigo e que já revisou tantas coisas na minha vida.

Ao meu tio Antônio Luiz Carvalho Leme, pesquisador do IBGE que me direcionou nos documentos, minha tia Elisabete Salay, professora do departamento de Engenharia Alimentar da Unicamp e Genilda Souza pelos caminhos compartilhados.

Principalmente gostaria de agradecer à minha família, aos irmãos Joana, Carlos e Nádia e meus avôs, pelo apoio de todas as horas mesmo daqueles que já foram. Aos meus pais Maria Cristina Salay e Alexandre Carvalho Leme, um especial agradecimento. Sem vocês esse trabalho não seria possível.

Por último, agradeço à CAPES, que me concedeu por dois anos apoio financeiro primordial para a realização deste trabalho. 


\section{RESUMO}

O termo feijão não designa apenas uma variedade de alimento, é um complexo léxico e botânico que engloba diferentes espécies. Apesar de já ser consumido na Europa desde a Antiguidade e na América há milhares de anos, após a colonização ele recebe nas terras americanas uma importância no sistema alimentar fundamental que vai além do fato de ter se tornado, paulatinamente, essencial para o consumo da população. Ele também ganhou um lugar protagonista na construção da imagem da nação brasileira. Primeiro percorremos como se constituiu esse processo para que o feijão se tornasse fulcral para falar de alimentação no Brasil. Depois, este trabalho procurou entender a produção desta leguminosa entre os anos de 1973 e 2009, como o alimento da nação é efetivamente consumido neste período e o discurso adotado sobre ele. $O$ recorte foi definido a partir das grandes pesquisas realizadas pelo Instituto Brasileiro de Geografia e Pesquisa, o IBGE, documentação utilizada, que nos permitiu traçar um amplo espectro do sistema alimentar brasileiro.

Palavras-chaves: feijão; identidade; alimentação; Brasil; IBGE. 


\begin{abstract}
The term bean does not designate only one variety of food, it is a lexicon and botanical complex that includes different species. Although it has been consumed in Europe since antiquity and in America for thousands of years, after colonization it receives in American lands fundamental importance in food system that goes beyond the fact of having become gradually essential for domestic consumption. He also gained a leading position in the construction of the image of the Brazilian nation. First, we searched how was constituted this process, which beans become central to talk about food in Brazil. Then, this study aimed to understand the production of this legume between the years 1973 and 2009 how the nation's food is actually consumed in this period and the discourse adopted on it. The period was defined based on the extensive research conducted by the Brazilian Institute of Geography and Research, IBGE, documentation that we used, which allowed us to draw a broad spectrum of Brazilian food system.
\end{abstract}

Keywords: beans; identity; food; Brazil; IBGE. 


\section{ÍNDICE DE FIGURAS, GRÁFICOS E TABELAS}

\section{Figuras}

Figura 01: O comedor de feijões, Annibale Carrache. 1583 ........................... 22

Figura 02: Distribuição do gênero Phaseolus no continente americano como

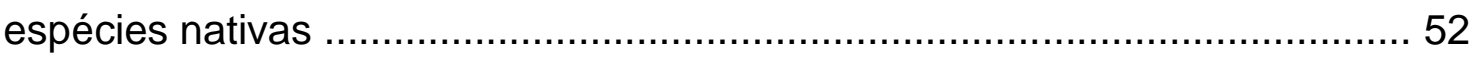

Figura 03: Distribuição do gênero Vignas enquanto nativas ......................... 54

Figura 04: Principais hábitos de crescimento dos cultivares ......................... 56

Figura 05: Peça gráfica de propaganda do Recenseamento Geral de 1940. Primeiro recenseamento feito pelo IBGE ............................................ 84

\section{Gráficos}

Gráfico 01: Produção de feijão por região .............................................. 61

Gráfico 02: Produção de feijão em 1975 (em toneladas) ..............................62

Gráfico 03: Produção de feijão em 1980 (em toneladas) ..............................63 63

Gráfico 04: Produção de feijão em 1985 (em toneladas) ..............................66

Gráfico 05: Produção de feijão em 1995 (em toneladas) ..............................69

Gráfico 06: Produção de feijão em 2006 (em toneladas) ............................ 70

Gráfico 07: Feijão no Brasil (FAO) ...................................................... 75

Gráfico 08: Disponibilidade de feijão entre os principais produtores (FAO) .... 79

\section{Tabelas}

Tabela 01: Raças e grupos gênicos do feijão-comum cultivado ...................... 55 Tabela 02: Área, produção e rendimento de feijão, safra 2002/2003, nos principais estados produtores do Brasil ................................................ 59

Tabela 03: Produção de feijão no Brasil - 1975-2006 (toneladas) ................. 60 Tabela 04: Produção de feijão - 1ำ, $2^{\circ}$ e $3^{\circ}$ Safra. (em mil toneladas) .............. 71 Tabela 05: Produção, importação e disponibilidade para alimentação (em toneladas) 
Tabela 06: Comparação da produção de feijão com outros países (toneladas) 77

Tabela 07: Nomenclatura dos feijões consumidos no Brasil (1973/1974) ..... 121

Tabela 08: Lista dos códigos dos alimentos ENDEF ................................... 132

Tabela 09: Consumo de feijão por região e áreas metropolitanas - 1973/1974

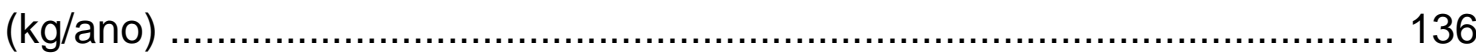

Tabela 10: Consumo de feijão segundo a POF - 1987/1988 (kg/ano) .......... 138

Tabela 11: Consumo de feijão nas regiões metropolitanas Brasil - 1995/1996

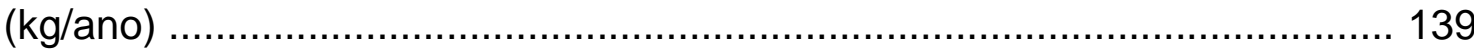

Tabela 12: Consumo de feijão nas regiões metropolitanas do Brasil 1995/1996 (gasto mensal por renda) ....................................................... 141

Tabela 13: Códigos correspondentes a feijão segundo a POF 2002/2003 ... 143

Tabela 14: Aquisição domiciliar de feijão - 2002/2003 (kg/ano) ................... 147

Tabela 15: Aquisição domiciliar de feijão por classes de rendimento familiar

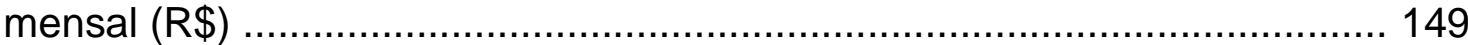

Tabela 16: Aquisição domiciliar de feijão - 2008/2009 (kg/ano) ................... 155 


\section{LISTA DE ABREVIATURAS E SIGLAS}

CBG - Conselho Brasileiro de Geografia

CDDI - Centro de Documentação e Disseminação de Informação

CFP - Companhia de Financiamento de Produção

CONAB - Companhia Nacional de Abastecimento

CRA - Comissão de Reforma Administrativa

EMBRAPA - Empresa Brasileira de Pesquisa Agropecuária

ENDEF - Estudo Nacional de Despesa Familiar

FAO - Organização das Nações Unidas para Alimentação e Agricultura

FIPE - Fundação Instituto de Pesquisas Econômicas

IAC - Instituto Agronômico de Campinas

IBGE - Instituto Brasileiro de Geografia e Estatística

INPC - Índice Nacional de Preços ao Consumidor

IPCA - Índice Nacional de Preço ao Consumidor Amplo

MAPA - Ministério da Agricultura, Pecuária e Abastecimento

POF - Pesquisa de Orçamentos Familiares

SIDRA - Sistema IBGE de Recuperação Automática

UA - Unidade de Alimentação 


\section{SUMÁRIO}

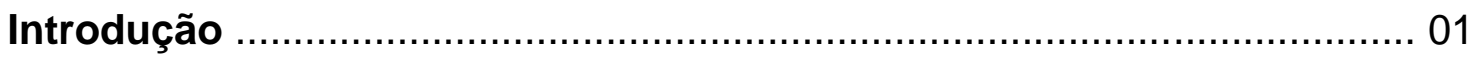

Capitulo 01 - Feijão, dono das tradições ................................................... 16

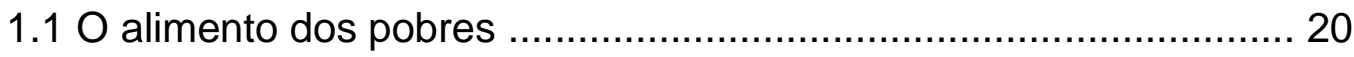

1.2 Feijão, o alimento da nação .......................................................... 24

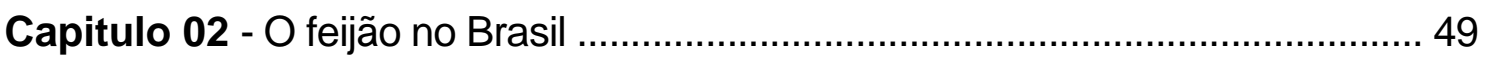

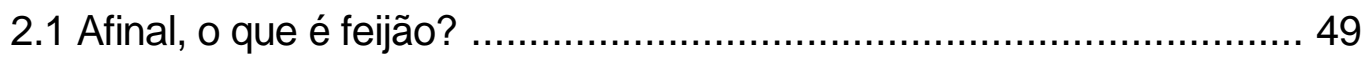

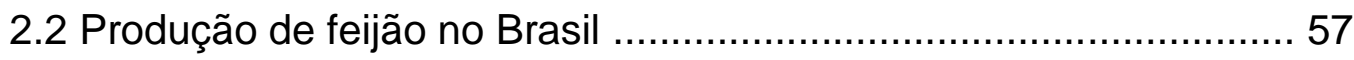

Capítulo 03 - O IBGE e as pesquisas alimentares ……................................ 80

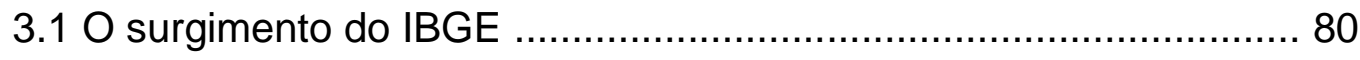

3.2 Definições metodológicas das pesquisas ...................................... 87

3.3 ENDEF - Estudo Nacional da Despesa Familiar ........................... 94

3.4 POF - Pesquisa de Orçamentos Familiares ................................ 102

Capítulo 04 - O feijão nas pesquisas sobre alimentação do IBGE ............... 120

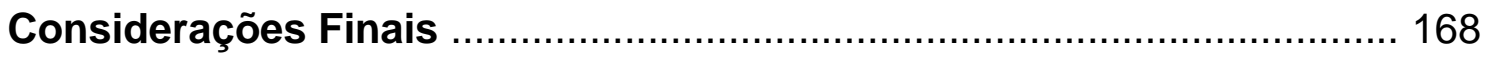

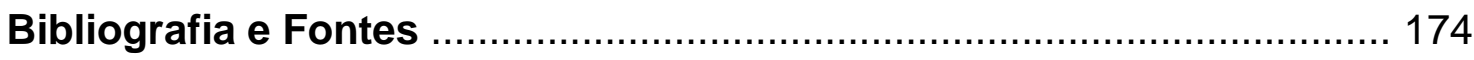




\section{Introdução}

"O feijão é de todos, a princípio, assim como a liberdade, o amor, o ar."1 Está no poema de Drummond, nos sambas, nas letras de Chico Buarque e em tantos outros lugares, que o feijão é o alimento nacional. Ele é narrado como o alimento brasileiro por excelência. Entendemos que a construção do discurso identitário parte sempre de elementos de sua própria realidade, sendo alguns selecionados para tal fim. Da mesma forma que a memória, que recorta essa realidade de acordo com seu objetivo. Neste sentido acontece com a alimentação -em uma ampla e complexa estrutura alimentar-, alguns objetos carregam uma carga simbólica maior que outros, principalmente alimentos que identificam um grupo e o separam de outro, tornando-o único.

Desta forma pensaremos, neste trabalho, o papel do feijão na identidade ${ }^{2}$ nacional. Tradição e transformação, contudo, não são opostos, e sim elementos do mesmo processo. Por mais que os hábitos estejam arraigados na sociedade e, por ser elemento estrutural, mudem muito lentamente, eles também estão sujeitos à passagem do tempo, às influências e às trocas que ocorrem com os deslocamentos. Assim olharemos para 0 período da pesquisa com o intuito de compreender como o consumo de feijão acontece e se transforma.

Entendemos que a análise desses hábitos não pode ser feita em um curto período de tempo. No prefácio do livro de Giovanni Arrighi, "O longo

\footnotetext{
1 ANDRADE, Carlos Drummond de. Amar se aprende amando. Rio de Janeiro: J. Olympio, 1985.

$2 \mathrm{O}$ conceito de identidade é complexo e fluido, principalmente no período proposto por esta pesquisa. Entendemos que identidade está intimamente ligada à ideia de reconhecimento, como nos diz Charles Taylor, identidade "designa algo que se assemelha à percepção que as pessoas têm de si mesmas e das características fundamentais que as definem como seres humanos. A tese é que nossa identidade é parcialmente formada pelo reconhecimento ou pela ausência dele, ou ainda pela má percepção que os outros têm dela (...). O não-reconhecimento ou o reconhecimento inadequado pode prejudicar e constituir uma forma de opressão, aprisionando certas pessoas em um modo de ser falso, deformado ou reduzido". TAYLOR, Charles. Multiculturalisme. Différence et démocratie. Paris: Flammarion, 1994.p 41-42.
} 
século $X X^{\prime \prime}$, o autor narra que Immanuel Wallerstein o alertou para a necessidade de recorrer à longa duração e ao diálogo entre as temporalidades de Braudel para poder abarcar o tipo de construção que pretendia. Assim pensamos nosso recorte temporal. Sem uma pretensão totalizante de interpretar o sistema, optamos por voltar, em um primeiro momento, para compreender como se deu a construção do imaginário nacional em torno do feijão. Essa análise é breve e tem um objetivo bem específico: quais eram e o que diziam as produções representativas nas quais o feijão aparecia? Qual imagem foi sendo associada ao feijão ao longo desse processo e como ele adquiriu essa carga simbólica? A função não é uma busca exaustiva de fontes e o esgotamento de todos os documentos que tratam deste alimento. Atentamo-nos ao que consideramos escritos relevantes na construção da representação. Seja qual for: os relatos de viajantes e o debate modernista.

A partir desta análise feita no primeiro capítulo, ou seja, a compreensão desta imagem atribuída ao feijão, propomos analisar o período que vai de 1973 a 2009 para, então, questionarmos como se dá o consumo de feijão no Brasil. O recorte foi atribuído pelas pesquisas que tratam da alimentação doméstica feitas pelo Instituto Brasileiro de Geografia e Estatística (IBGE). Nosso foco são as transformações nos hábitos alimentares no período contemporâneo e o questionamento dessa imagem fixa do feijão como alimento fundamental da cozinha brasileira. Como, após a urbanização e industrialização que ocorreram no Brasil, as diferentes trocas e influências, ele esteve presente na mesa do brasileiro? O feijão seria, assim, o alimento da nação?

Alguns autores que pensam sobre a questão dos hábitos alimentares contemporâneos se questionam sobre a pasteurização ou, como diria Claude Fischler 4 , "mcdonaldização" dos costumes. Para esta corrente de pensamento, certos países, principalmente de tradição católica, começaram a temer que seus hábitos e costumes ${ }^{5}$ estivessem ameaçados pela introdução de novas

\footnotetext{
${ }^{3}$ ARRIGHI, Giovanni. O longo século XX. São Paulo: Unesp, 1996. p. XIII.

4 FISCHLER, Claude. "A 'McDonaldização' dos costumes". Em: FLADRIN, Jean-Louis \& MONTANARI, Massimo (dir.). Historia da Alimentação. São Paulo: Estação Liberdade, 1998.

${ }^{5}$ Eric Hobsbawn e Terence Ranger no livro $A$ invenção das tradições, diferenciam tradições de costumes. Para eles, 'o objetivo e a característica das 'tradições', inclusive das inventadas, é a invariabilidade. O passado real ou forjado a que elas se referem impõe práticas fixas, tais como a repetição. $\mathrm{O}$ 'costume', nas sociedades tradicionais, tem a dupla função de motor e volante.
} 
formas da relação com o alimento. O que antes era um momento de destaque, de prazer e de sociabilidade estava sendo paulatinamente substituído pelo

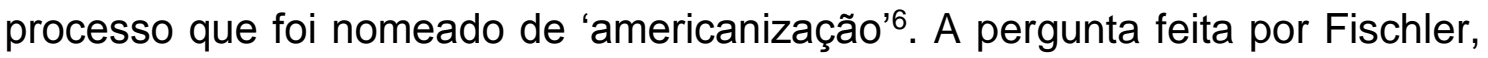
cuja corrente de pensamento perpassa este trabalho, é: "será que se trata verdadeiramente do coroamento de um processo histórico de racionalização, industrialização e funcionalização da alimentação?"7. Porém, focamos principalmente na questão da identificação nacional na esfera da alimentação dentro deste contexto. Propomos entender como é o consumo de feijão durante o período proposto, alimento identificado como típico e presente desde 0 período colonial.

Diante desse contexto, optamos por desenvolver a dissertação de mestrado em quatro momentos. No primeiro iremos entender como o feijão, considerando todos os problemas de definição do que engloba este substantivo, passa a ser identificado como alimento tipicamente nacional. Nos concentraremos, principalmente, nas primeiras décadas do século $\mathrm{XX}$, quando a questão nacional foi amplamente discutida tanto como projeto político quanto como produção cultural. Esse processo de construção não se limita a este período, mas o entendemos como momento importante para compreender a representação que o alimento tem na criação do mito da nação. Tal busca está associada a um projeto, qual seja, a criação de uma imagem nacional única daquilo que se pretendia passar. A partir dos fatos vividos, observados, que se enquadram como espaço de experiência, se projetava um horizonte de expectativa $^{8}$ - "expectativa abarca mais que a esperança, e a experiência é mais profunda do que a recordação -são constitutivas, ao mesmo tempo, da história e de seu conhecimento, e certamente o fazem mostrando e produzindo a relação interna entre passado e futuro, hoje e amanhã."

Não impede as inovações e pode mudar até certo ponto, embora evidediscuntemente seja tolhido pela exigência de que se deve parecer compatível ou idêntico ao precedente". In: HOBSAWN, Eric e RANGER, Terence. A invenção das tradições. Rio de Janeiro: Paz e Terra, 2008. p. 10.

6 FISCHLER, Claude. “A 'McDonaldização' dos costumes”... Op. Cit. p. 844.

7 Idem, ibidem. p. 844.

8 KOSELLECK, Reinhart. Futuro Passado - contribuição à semântica dos tempos históricos. Rio de Janeiro: Contraponto, 2006. P. 305-328.

${ }^{9}$ Idem, ibidem. p. 308. 
No segundo capítulo procuramos entender como se define o termo feijão, uma tentativa de clarear a confusão léxica e botânica. No Brasil, o termo envolve basicamente dois gêneros - Phaseolus, ou chamado de feijão-comum, de origem americana, sendo o Phaseolus vulgaris a espécie mais presente, e o Vigna, que recebe o nome vulgar de feijão-caupi e tem origem na África e na Ásia. Este capítulo apresenta um breve panorama da produção de feijão no Brasil durante o período da pesquisa. Pudemos apreender dados interessantes, como o fato de o país nunca ter sido autossuficiente no plantio de tal alimento durante os anos pesquisados e de a China ter passado a exportadora de feijão para o Brasil no último período.

Elucidamos brevemente as balizas teóricas pelas quais nos baseamos para esta pesquisa, principalmente as temporalidades históricas e o lugar do alimento nas discussões. Enquanto foco de estudos relativamente recentes, iremos entender o debate da historiografia da alimentação sem deixar de lado as outras áreas das ciências. Propomos um olhar eminentemente multidisciplinar sobre as questões dos hábitos alimentares, focando nas mudanças contemporâneas após as Revoluções Industriais e Tecnológicas. Como essas transformações centrais provenientes da industrialização e da urbanização modificaram a esfera cotidiana da refeição e da relação do homem com o alimento. No terceiro capítulo apresentamos a formação do IBGE e a constituição metodológica de suas pesquisas alimentares que foram objeto de análise neste trabalho. Um longo período como o adotado aqui, quase 40 anos, perpassa diferentes contextos sócio-políticos elucidados ao longo do texto. A partir daqui trabalhamos principalmente com duas fontes documentais: as pesquisas alimentares do IBGE e sua repercussão na imprensa, focando nos jornais Folha de São Paulo e Estado de São Paulo e na revista Veja.

No quarto e último momento confrontaremos os dados de consumo doméstico para analisar como, durante este período, se modificaram as formas e quantidade de consumo de feijão no Brasil. Analisamos aqui o ENDEF (Estudo Nacional de Despesa Familiar) feito em 1973/1974 pelo IBGE e que delimita o início do nosso recorte temporal e as POF (Pesquisa de Orçamentos Familiares) realizadas pelo IBGE em 1987/1988 e 1995/1996 nas áreas metropolitanas do país, as POF nacionais realizadas em 2002/2003 e 
2008/2009 também pelo IBGE demarcando o final do período proposto. Partimos dessas análises para entender o heterogêneo consumo desse alimento e a discussão com a representação na mesa do brasileiro.

Enfim, o presente estudo é um meio pelo qual questionaremos a relação contemporânea da identidade nacional projetada no cotidiano alimentar, a desconstrução de um discurso hegemônico aplicado às últimas quatro décadas. Como as práticas alimentares ditas seculares e permanentes estão no cotidiano doméstico que recebe periodicamente novos fluxos de ideias e influências. $E$, ainda, as mudanças da relação homem/alimento e homem/identidade dentro da esfera cotidiana globalizada.

Importante esclarecer que não entendemos que há uma separação clara entre identidade e consumo. Quando consumimos o fazemos por pertencemos a um determinado espaço/tempo que dita tendências ao nosso comportamento. Porém, as categorias que Klass Woortmann ${ }^{10}$ trata elucidam nossa análise. Woortmann diferencia o padrão idealizado de consumo alimentar e o consumo efetivo. O consumo alimentar idealizado é aquele que usamos na representação da identidade social, enquanto 0 alimento efetivamente consumido está mais sensível às mudanças ocasionadas pelo mercado, queda ou aumento na renda e disponibilidade. Trata-se do alimento a que temos acesso, que flutua e se modifica paulatina e constantemente. Em outras palavras, consumimos também identidade. Muitas vezes ela é a baliza do consumo, porém menos rígida e fixa do que prega o discurso. Parte da hipótese inicial é que essa expectativa, essa referência de consumo, deslocouse para uma perspectiva além do nacional. Nossa pretensão nesta pesquisa, contudo, é desconstruir esse discurso homogêneo e tratá-lo dentro do fenômeno contemporâneo da industrialização alimentar que aparece principalmente, mas não exclusivamente, nos meios urbanos.

Se partimos de um olhar de certa forma geral do sistema capitalista, temos que ter em mente que o alimento envolve muitas esferas e toda uma cadeia produtiva - a terra que é plantada e a relação social envolvida nisso;

10 WOORTMANN, Klass. "Hábitos e Ideologias alimentares em grupos sociais de baixa renda". Relatório Final. Série Antropologia, v.20, Universidade de Brasília, 1978. p.45-47. 
como ela é distribuída; como os setores sociais se posicionam a respeito e tantas outras facetas. Sem querer deixá-las de lado, já que tratamos brevemente deste tema no segundo capítulo, esta pesquisa de mestrado se debruçará primordialmente nas transformações das formas de se alimentar enquanto consequência de fenômenos em torno da globalização, industrialização e mercantilização do alimento no âmbito doméstico. Por mercantilização entendemos a tendência contemporânea de individualização e fetichização que tornam o ato de se alimentar expressivo para compreender transformações na convivialidade.

Ao longo da pesquisa, nos deparamos com questionamentos centrais sobre os enfoques teóricos pertinentes a este trabalho que determinariam sua direção. Quais seriam as categorias a serem empregadas quando abordamos a análise do discurso nacional ${ }^{11}$ a partir de dados econômicos e de consumo contemporâneos? Como posicionar os pressupostos teóricos para compreender as transformações ocorridas nestas décadas? Como tratar as diferentes temporalidades históricas que optamos por abordar neste trabalho? Quando olhamos para os fatos, os dados ou fontes históricas, o fazemos a partir de conceitos e categorias que estão, na maioria das vezes, descolados daquela realidade observada. Sabemos que os documentos nos fornecem informações intrínsecas, mas que também o observamos a partir de determinadas ferramentas que precisam ser expostas.

Desta forma, o recorte temporal é fundamental para o entendimento do processo histórico. As datas e cronologia são diferentes do que pressupomos como tempo histórico. A cronologia é o tempo corrido do calendário, a caracterização e numeração do tempo que corre, a sequência de números que nos auxilia na localização do tempo. Já o tempo histórico é a apreensão em um fenômeno, de um processo que é mutável, não é fixo. É a ferramenta do historiador que deve ser dada a partir do objeto observado, deve variar de acordo com a análise. Quando observamos a dinâmica de uma feira livre, por exemplo, podemos notar um conjunto de barracas e seus comerciantes que se

\footnotetext{
${ }^{11}$ Entendemos "discurso nacional" não apenas a expressão verbal daquilo que é construído a partir de uma tendência nacionalista ou a demonstração nacional, mas também as formas de expressão que ajudam a "criar" uma nação, a moldá-la.
} 
instalam uma vez por semana naquele pré-determinado endereço. Como sabemos, a feira está circunscrita em um tempo, uma data -acontece toda quarta-feira desde sete de março de 1999. Mas a apreensão das temporalidades que envolvem as dinâmicas desta feira são construídas historicamente e possivelmente distintas - as cadeias dos alimentos que estão expostos, como se deu o crescimento ou queda do consumo de determinado alimento, a formação desta cadeia ou a variação de preço em um determinado período; a rua e sua formação urbana, projetos políticos que mudaram as características do bairro ou os trajetos das reformas urbanas; os profissionais que ali estão, regime de trabalho, tendências migratórias e seus hábitos.

Fernand Braudel se torna mais uma fonte de inspiração e bases para categorias explicativas do que um modelo a seguir. Sua pretensão de uma história totalizante não é o objetivo deste trabalho. Charles Tilly faz uma observação sobre a obra do autor nos alertando que a "soma de todas as teorias, infelizmente, não é teoria alguma"12. Porém, seus estudos sobre temporalidade são importantes para entender como construímos a base de análise. Para elucidarmos melhor essas escolhas, precisamos no debruçar sobre o livro que marca os estudos braudelinos - Escritos sobre a história. No capítulo "História e Ciências Sociais - a longa duração", Braudel propõe que o homem não tem apenas um tempo, ele tem múltiplos tempos contraditórios que, além de passado, são também formados pelo estofo da vida social atual ${ }^{13}$. O autor nos apresenta a divisão tripartite dos tempos históricos.

Há o tempo breve, do evento, que é o explosivo e de curta duração. É o tempo do cronista e jornalista, que a Ciência Social tem horror e para ele, não sem razão, "o tempo curto é a mais caprichosa, a mais enganadora das durações"14. Já as variações econômicas, de preços e salários, por exemplo, precisam de tempos maiores para serem apreendidas. Neste está a conjuntura, tempo de uma dezena de anos e podendo chegar ao meio século do ciclo

12 TILLY, Charles. Big Structures, Large Processes, Huge Comparisons. Nova York: Hussel Sarge. 1984 , p. 71.

13 BRAUDEL, Fernand. Escritos sobre a história... Op. Cit.

${ }^{14}$ Idem, ibidem. p. 46. 
clássico de Kondratieff ${ }^{15}$. E há a longa duração, que pode ser de amplitude secular, dominada pela estrutura. Por estrutura Braudel entende ${ }^{16}$ :

uma organização, uma coerência, relações bastante fixas entre realidades e massas sociais. Para nós, historiadores, estrutura é, sem dúvida, articulação, arquitetura, porém, mais ainda, uma realidade que o tempo utiliza mal e veicula mui longemente. (...) São, ao mesmo tempo, sustentáculos e obstáculos. Obstáculos assinalam-se como limites dos quais o homem e suas experiências não podem libertar-se. (...) $O$ exemplo mais acessível parece ainda o da coerção geográfica.

Entendemos que, para a compreensão da maneira como o feijão se tornou um alimento emblemático da cozinha brasileira, é necessária uma análise de longa duração, já que os hábitos e a construção de suas representações se formam a partir de demorados processos históricos. Nos estudos históricos culturais essa visão foi adotada por Lucien Febvre em seu famoso livro O problema da incredulidade no Século XVI - a religião de Rabelais ${ }^{17}$. Aqui o autor foi observar o comportamento e mecanismos culturais que estavam presentes desde muito antes do tempo de Rabelais para entender a incredulidade do século XVI. Para Braudel, segundo Giovanni Arrighi ${ }^{18}$, estaria nesta esfera da longuíssima duração, o tempo completo do sistema capitalista, com quatro ou cinco séculos de história.

Portanto, nas diversas instâncias, mesmo nos ciclos econômicos ou nos acontecimentos políticos, há permanências na forma de pensar ou agir, assim como nos hábitos alimentares. Porém, é válido ressaltar que sua imobilidade não é absoluta e ela está sujeita a rupturas muito afastadas uma das outras. Cabe aqui a diferenciação que Koselleck faz entre evento e estrutura. Para este autor, evento só pode ser narrado e estrutura só pode ser descrita. Isso quer dizer que o evento, enquanto fato ou sucessão de acontecimentos que são retirados dos documentos, pode ser contado cronologicamente e por isso

\footnotetext{
15 Idem, Ibidem. p. 47.

16 Idem, ibidem. p. 49-50.

17 FEBVRE, Lucien. O problema da incredulidade no Século XVI - a religião de Rabelais. São Paulo: Cia das Letras, 2009.

${ }^{18}$ ARRIGHI, Giovanni. Op. Cit. p. XI.
} 
foi tão valorizado. Neste caso o evento está preso a sucessão temporal, com um antes e um depois. Já por estrutura ele entende ${ }^{19}$

aquelas circunstâncias que não se organizam segundo a estrita sucessão de eventos passados. Elas implicam maior duração, maior estabilidade, alterando-se em prazos mais longos. (...) A referência a uma 'justaposição de camadas' [Schichtung], cujo sentido original é espacial, tendendo ao estático, está presente no radical do substantivo 'história' [Geschichte]

A primeira, na longuíssima duração, pretendemos enquadrar a formação da imagem do feijão em um espaço de tempo maior. Resgatamos brevemente, no primeiro capítulo, relatos dos viajantes no Século XVI para captar os registros dos usos de feijão e nos detivemos no debate Modernista. E, como pretendemos captar as transformações do consumo e das práticas culinárias na contemporaneidade, optamos por um recorte das fontes a primeira vista amplo, de quase quarenta anos (1973-2009). Se nosso foco central é entender o consumo de feijão -estamos lidando com hábitos, ou como alguns preferem, práticas culinárias ${ }^{20}$. É preciso compreender que estes são comportamentos que perpassam o tempo e de forma lenta vão se modificando.

A segunda etapa de análise começa em 1973 e vai até 2009. A periodização é aparentemente atípica dentro do debate histórico, mas necessária. Quando tratamos da transformação de hábitos ou práticas temos que olhar para um período de tempo maior que o do evento. Por um breve momento podemos nos pegar pensando que talvez, no final desta pesquisa, se seguirmos o pensamento de Braudel, acabamos por notar que o recorte adotado foi curto. Afinal, se estamos lidando com hábitos, costumes e suas

\footnotetext{
${ }^{19}$ KOSELLECK, Reinhart. Op. Cit. p. 135.

20 Para uma corrente, o termo "práticas" seria mais adequado, pois por hábito eles entendem uma rigidez que não seria pertinente. Para Lívia Barbosa "O conceito de hábitos implica a pressuposição da existência de um padrão repetitivo de práticas e representações, que se reproduziriam no interior da sociedade". In: BARBOSA, Lívia. "Feijão com arroz e arroz com feijão: o Brasil no prato dos brasileiros". Horizontes Antropológicos, Porto Alegre, ano 13. n. 28 , jul/dez 2007. Por hábitos alimentares adotamos a definição dada por Mead e Guthe em 1945, no Manual for the Study of Food Habits: "o estudo dos meios pelos quais os indivíduos, ou grupo de indivíduos, respondendo a pressões sociais e culturais, selecionam, consomem e utilizam porções do conjunto de alimentos disponíveis." Apud BLEIL, Susana Inez - "O Padrão Alimentar Ocidental: considerações sobre mudanças de hábitos no Brasil". In: Cadernos de Debate, Vol. VI, 1998. p. 02.
} 
transformações, precisaríamos abranger o tempo da longa duração em sua plenitude. Porém, admitimos, em princípio, que este é um recorte de um tempo suficientemente grande para constatar mudanças expressivas.

Se por um lado seriam mais visíveis as mudanças nesse tempo da longa duração, o tempo secular, por outro, temos que levar em consideração que a principal atribuição do historiador é partir do contexto que seu objeto de análise faz parte e não tentar enquadrá-lo em um modelo explicatório. Temos como hipótese inicial que o Brasil, nosso lugar de análise, está em grande desenvolvimento industrial e urbano no período, em que as grandes redes de supermercados se instalam e há um crescimento significativo das redes de fast food. Em segundo lugar as pesquisas de consumo, além de empregarem metodologia muito distinta ao longo do tempo, são mais raras antes desse recorte.

O tempo passa a ser dado pelos próprios objetos de pesquisa, e assim podemos perceber os diferentes tempos dialogando. Chuvas ou estiagens podem fazer modificar o hábito alimentar na curta duração, pela colheita prejudicada; o alimento costumeiro da elite pode, na média duração, popularizar-se e deixar de ter o prestígio de outrora; a necessidade de distinguir-se socialmente, de marcar sua procedência, persiste teimosamente, sobrevivendo a colheitas, governos e costumes ${ }^{21}$.

Podemos perceber ao longo dele mudanças políticas significativas. No início, quando foi realizada a primeira pesquisa, o Brasil estava em um regime político ditatorial, no discurso do milagre econômico. A primeira Pesquisa de Orçamentos Familiares (POF) é feita em 1987-1988, no contexto da abertura política e crise econômica, sendo que a segunda acontece em 1996-1997, implantação do plano Real e mudança na forma de consumo e as duas últimas, em 2002-2003 e 2008-2009, quando há a estabilização do plano e mudanças no poder de compra da população. Esses diferentes períodos históricos são colocados em questão, mas não desqualificam uma análise dos hábitos alimentares que perpassam muitas mudanças políticas sem deixar de ser influenciados por elas.

${ }^{21}$ BRAUDEL, Fernand. Civilização material... Op. Cit. p.146-7. 
Por último, e tão importante quanto às outras colocações braudelianas, aparece a perspectiva eminentemente multidisciplinar. Apesar de partir de uma visão histórica, não há porque restringir em uma área toda a complexidade do objeto de estudo. Não há amarras para o conhecimento, nós que adotamos a velha mania de tentar colocá-los em departamentos rígidos. O historiador nos chama atenção para a necessidade de maior diálogo entre as Ciências Sociais, cada uma em sua especificidade. No caso da História, ela conduziria as outras disciplinas através do tempo. Por exemplo, Braudel, em um amplo debate com os estruturalistas, fala de seu objetivo de alcançar a zona dos elementos inconscientes, cita o trabalho de Levis-Strauss sobre os mitos e a maneira de ser na cozinha. Levis-Strauss estava à procura do inconsciente que nos faz falar sem nos preocupar com os fonemas, assim como sentamos à mesa sem nos preocupar com os "gustemas"22. A necessidade da aproximação não está vinculada apenas a este tema. A história não tem um tema que seja exclusivamente seu - "a história como ciência distingue-se apenas pelos seus métodos." ${ }^{23}$ Mas queremos chamar atenção para o fato de, quando falamos de hábitos alimentares, estarmos lidando invariavelmente com um campo de várias frentes de estudos. Sendo assim, faz-se necessário não apenas assumir que o campo tem múltiplas óticas, mas adotá-las quando necessário porque "alimentação, além de uma necessidade biológica, é um complexo sistema simbólico de significados sociais, sexuais, políticos, religiosos, éticos, estéticos, etc." ${ }^{24}$ Como tal, ela precisa ser entendida a partir não apenas de uma interpretação biológica, mas também como marcadora social, de gênero, que carrega tabus religiosos ou identidades.

Quando observamos 0 ato de comer temos que, além das calorias e nutrientes, observar produção, a distribuição, a aquisição, as cargas simbólicas, os rituais e tantas outras esferas que envolvem uma das mais elementares ações humanas. Assim, "um empreendimento de pesquisa que visa esclarecer não apenas o que e quanto foi comido quando e onde, mas acima de tudo, por quais razões algo foi comido dessa maneira específica,

\footnotetext{
22 BRAUDEL, Fernand. Escritos sobre a história... Op. Cit. p. 67.

${ }^{23}$ KOSELLECK, Reinhart. Op. Cit. p. 120.

${ }^{24}$ CARNEIRO, Henrique. Comida e sociedade: uma história da alimentação. Rio de Janeiro: Campus, 2003. p. 01.
} 
possui, obviamente, uma amplitude desmesurada." ${ }^{25}$ Nesses múltiplos olhares, dialogamos estreitamente com a sociologia e antropologia da alimentação, principalmente por tratarmos de um período bem recente quando falamos em História-de 1973 a $2009^{26}$.

A alimentação da época atual, com intensificação comercial, a adoção de novas tecnologias de produção, distribuição $e$ consumo de alimentos, a expansão de novos hábitos homogeneizados pelas grandes cadeias de lanchonetes e outros fenômenos recentes têm sido abordados pela sociologia da alimentação contemporânea sob múltiplos ângulos.

A discussão sobre hábitos alimentares dentro das Ciências Sociais é relativamente recente. Hoje podemos considerar que existem importantes autores e trabalhos sobre o tema, mas até pouco tempo era necessário justificar a necessidade de se falar sobre alimentação através de uma perspectiva humana. No texto produzido em 1999 para a revista Culture and Agriculture, Warren Belasco escreve "Why food matters", para justificar a pertinência de se estudar o comportamento alimentar nas variadas perspectivas. Ele nos diz: "Food is the first of the essentials of life, our biggest industry, our greatest export, our most frequently indulged pleasure, and also the object of considerable concern and dread." ${ }^{27}$

O alimento ${ }^{28}$ tem uma imensa importância histórica - foi responsável por revoluções tecnológicas, desde quando o homem passou a dominar a técnica de produção na era Neolítica. Também objeto de disputas e conquistas - como

\footnotetext{
${ }^{25}$ Idem, ibidem. p. 04.

${ }^{26}$ Idem, ibidem, p. 18-19.

27 Tradução livre: "comida é nossa primeira necessidade para a vida, nossa maior indústria, nosso maior artigo de exportação, o mais frequente espetacular prazer e também um objeto de preocupação e medo." BELASCO, Warren. "Why food matters". In: Culture and Agriculture. Vol 21, n. 01. Spring 1999. p. 27-34.

28 Para Lívia Barbosa, quando falamos de alimento estamos lidando mais com dados quantitativos Já por refeição ela entende: "Toda a sociedade estabelece normas e momentos específicos, em que determinados tipos de comida são ingeridos preferencialmente a outros, em uma determinada sequência, dentro de certa lógica de ingestão e de combinação dos alimentos entre si. Esses momentos são denominados refeições." Define a combinação de alimentos, manipulação, técnicas de cocção, representações e práticas sobre as comidas e as refeições como culinária - principal mecanismo que transforma alimento em comida. BARBOSA, Lívia. "Feijão com arroz e arroz com feijão: o Brasil no prato dos brasileiros". Horizontes Antropológicos, Porto Alegre, ano 13. n. 28, jul/dez 2007.
} 
o sal, por exemplo; foi elemento central dentro do comércio mundial e história das trocas -basta olharmos para o açúcar. Então por que, de uma perspectiva histórica e mesmo das Ciências Humanas, um autor em 1999 precisa escrever um texto com o nome: "Why food matters"?

Segundo ele mesmo -“(...) some people are surprised when academics do anything that touches on daily life." ${ }^{29} \dot{E}$ consenso que o tema da alimentação, com enfoque histórico e social, é aceito como "sério" e aprovado pela academia há relativamente pouco tempo. $O$ que antes existiam eram trabalhos esporádicos de autores que não tinham esse tema como central ou textos produzidos para o grande público. Em outros aspectos, geralmente este assunto estava englobado dentro de outras disciplinas, como folclore ou etnografia e assim, por muito tempo, a história da alimentação se manteve fora do perímetro dos assuntos aprovados, o que quer dizer que avançava por marginalizadas pesquisas.

Quando pretendemos entender um contexto ou um momento histórico nenhum aspecto da realidade é banal que não deva ser levado em consideração. $\mathrm{O}$ debate em torno das práticas alimentares ganhou espaço e destaque dentro da perspectiva histórica, principalmente a partir da Escola de Annales. Nessa corrente de pensamento, quem apontou para a questão dos hábitos alimentares foi Lucien Febvre, quando, em 1938, falou sobre elementos fundamentais que faziam parte dos sistemas culinários, os "fundos de cozinha". Estes estariam tão arraigados a uma cultura que resistiriam as transformações impostas ou paulatinas como conquistas, mudanças, migrações ou revoluções tecnológicas ${ }^{30}$. Contribuição fundamental dentro dessa corrente é a de Fernand Braudel que, na tentativa de uma história totalizante, apontou para as estruturas que carregam os elementos mais permanentes da sociedade, como mostramos anteriormente.

A partir da "Nova História", a história da alimentação passa a ser levada a sério. Concomitante a esta discussão merece destaque o trabalho do

29 Tradução livre: "algumas pessoas ficam surpresas quando acadêmicos estudam qualquer coisa que tenham contato diário" BELASCO, Warren. O que iremos comer amanhã - uma história do futuro da alimentação. São Paulo: Editora Senac São Paulo, 2009. p. 27.

30 BLEIL, Susana Inez. Op. Cit. 
antropólogo Lévi-Strauss que escreve $O$ cru e o cozido, Do mel às cinzas e $A$ origem da maneira à mesa. Cozinhar, para ele, seria a passagem do estado natural para o estado cultural. Sua contribuição para o pensamento sobre hábitos, também os alimentares, vai além da antropologia e perpassa as Ciências, sendo um expoente da escola estruturalista. Esse impulso inicial fez com que surgissem outros grandes estudos de História da Alimentação como Roland Barthes, Paul Arion, Robert Mandrou, entre outros.

$\mathrm{Na}$ Inglaterra ocorreu um processo parecido, com o marco em 1963, quando a "University of London promoveu o Seminário de Historiadores e Nutricionistas do Queen Elizabeth College (...) que foi na opinião de Derek Oddy 'a mais duradoura e produtiva fonte de trabalhos em história dietética e da alimentação'"31. Henrique Carneiro nos mostra como tendência internacional o crescimento de estudos desse gênero na primeira metade do século XX Espanha com Cereceda (1934), no México com Espinosa (1939), Colômbia com Bejarano (1941), são apenas alguns ${ }^{32}$. No Brasil podemos citar os trabalhos pioneiros de Luis Câmara Cascudo, Gilberto Freyre e Manuel Querino. Enfim, a partir desses trabalhos que apareceram em lugares distintos mas, podemos dizer, dentro de um panorama semelhante, a alimentação começa a ser estudada enquanto objeto histórico. Essa historiografia "tem se constituído nas últimas décadas como uma síntese multidisciplinar”33.

Hoje sabemos que a escolha do alimento, do método de preparo e das formas de refeições não está ligada apenas ao caráter biológico. Ela é cercada de outras questões que englobam vários âmbitos. A palavra escolha, em si, já é representativa deste múltiplo caráter, porque é também chamada de gosto. $\mathrm{E}$ gosto tem significâncias interessantes, porque esse termo pode ter o sentido de sabor de um alimento, paladar. Mas também é ato de escolha e opinião. Por isso, o gosto, enquanto paladar, não é determinado apenas pela língua. $O$ órgão do gosto é o cérebro. "Um órgão culturalmente (e, por isso,

\footnotetext{
${ }^{31}$ CARNEIRO, Henrique. Comida e sociedade. Op. Cit. p. 143.

${ }^{32}$ CARNEIRO, Henrique. Comida e sociedade. Op. Cit. p. 134.

33 Idem, ibidem. p. 168.
} 
historicamente) determinado, por meio do qual se apreendem e transmitem critérios de avaliação." 34

${ }^{34}$ MONTANARI, Massimo. Comida como cultura. São Paulo: Senac, 2008. p. 95. 


\section{Capitulo 01 \\ Feijão, dono das tradições}

Para o povo, uma refeição sem feijão é simples ato de enganar a fome. Não de alimentar-se. Não há refeição sem feijão.

\section{Luis da Câmara Cascudo}

Ele está na música, na literatura, no cinema e na pintura. Em diversas manifestações artísticas e literárias o feijão é citado como alimento do brasileiro. No álbum Construção, de 1971, do compositor Chico Buarque, duas músicas se destacam. A primeira, "Construção"35, narra a vida e morte de um trabalhador e nela ele aparece (grifo nosso):

Sentou pra descansar como se fosse um príncipe

Comeu feijão com arroz como se fosse o máximo

Bebeu e soluçou como se fosse máquina

Dançou e gargalhou como se fosse o próximo

"Comeu feijão com arroz como se fosse o máximo". Como se fosse, mas não é, é o alimento do trabalhador, aquele ordinário. Em outra canção, "Cotidiano"36, Chico Buarque mostra o dia a dia de um casal (grifo nosso):

Todo dia eu só penso em poder parar;

Meio-dia eu só penso em dizer não,

Depois penso na vida pra levar

E me calo com a boca de feijão

Aqui o autor fala daquilo que "se faz sempre igual", da repetição do casal, para ele falar de cotidiano é falar de feijão. Francisco Santana, em 1977 escreve o samba "Saco de Feijão"37, entoada mais tarde na voz de Beth Carvalho, que descrevia como a inflação repercutia no bolso e mesa do trabalhador (grifo nosso):

${ }^{35}$ BUARQUE, Chico. Construção. In: BUARQUE, Chico. Construção. Rio de Janeiro: Philips, 1971.

${ }^{36}$ BUARQUE, Chico. Cotidiano. In: BUARQUE, Chico. Op. Cit.

37 SANTANA, Francisco. Saco de Feijão. In: CARVALHO, Beth. Firme e forte no pagode. Rio de Janeiro: Sony, 2004. 
Eu ia no armazém do seu Manoel com um tostão

Trazia um quilo de feijão

Depois que inventaram o tal cruzeiro

Eu trago um embrulhinho na mão

De deixo um saco de dinheiro.

A inflação galopante desvalorizou a moeda e para comprar aquele item mais básico agora era preciso um saco de dinheiro. Mais enfático ainda é a letra de Gonzaguinha que ganhou fama na voz do grupo Frenéticas, "O preto que satisfaz"38 (grifo nosso):

Dez entre dez brasileiros elegem feijão!

Puro, com pão, com arroz

com farinha ou macarrão

macarrão, macarrão!

E nessas horas que esquecem dos seus preconceitos

gritam que esse crioulo

é um velho amigo do peito

A letra é categórica, todos os brasileiros querem feijão, aquele que une a todos, as diferenças se dissipam no prato. A música um pouco mais tarde foi tema de uma telenovela da Rede Globo, Feijão Maravilha, escrita por Bráulio Pedroso em 1979.

Carlos Drummond de Andrade, no poema "A excitante fila do feijão", que faz parte do livro Amar se aprende amando, 1985 fala $^{39}$ (grifo nosso):

Larga, poeta, a mesa de escritório, esquece a poesia burocrática

e vai cedinho à fila do feijão.

(...)

38 GONZAGUINHA, O preto que satisfaz. In: FRENÉTICAS, Caia na Gandáia, Rio de Janeiro: Warner 1978.

${ }_{39}$ ANDRADE, Carlos Drummond de. Op. Cit. 
Dez, doze ou mais: o tempo não importa quando aperta o desejo brasileiro de ter no prato a preta, amiga vagem.

Camburões, patrulhinhas te protegem e gás lacrimogêneo facilita o ato de comprar a tua cota.

O feijão é de todos, em princípio, tal como a liberdade, o amor, o ar. Mas há que conquistá-lo a teus irmãos.

A conta-gotas vai-se escoando o estoque armazenado nos porões do Estado. Assim não falta nunca feijão-preto (embora falte sempre nas panelas). Método esconde-pinga: não percebes que ele torna excitante a tua busca? Supermercados erguem barricadas contra esse teu projeto de comer. Há gritos, há desmaios, há prisões.

Suspense à la Hitchcock ante as cerradas portas de bronze, guardas do escondido papilionáceo grão que ambicionas.

na dimensão dramática da luta por um ideal pedestre mas autêntico:

Feijão! Feijão, ao menos um tiquinho! Caldinho de feijão para as crianças... Feijoada, essa não: é sonho puro, mas um feijão modesto e camarada 
que lembre os tempos tão desmoronados

em que ele florescia atrás da casa

sem o olho normativo da Cobal.

\section{(...)}

Larga, poeta, o verso comedido,

a paz do teu jardim vocabular,

e vai sofrer na fila do feijão.

Carlos Drummond escreve no poema uma profunda crítica social: "o tempo não importa/ quando aperta o desejo brasileiro/ de ter no prato a preta, amiga vagem". Mais uma manifestação artística na qual o alimento aparece associado à refeição para o povo. Sofrida e básica, a expressão de brasilidade que acolhe, amiga vagem. Aquela que antes era mantida no quintal de casa e agora é intermediada pelo supermercado e pelo Estado, que controla a cota.

Outro autor, Eduardo Frieiro, em seu livro Feijão, Angu e Couve, escreve: "Feijão é que escora a casa, diz o rifão popular" ${ }^{40}$. O sociólogo Carlos Alberto Dória, em sua recente publicação ${ }^{41}$, afirma que o feijão é o prato nacional por excelência. Podemos perceber que, no período que a pesquisa abarca, o feijão já está consagrado como alimento da nação. A proposta deste primeiro capítulo, enfim, é entender nosso objeto de estudo, o feijão, principalmente no que tange à sua associação com a brasilidade e ao mito da unidade nacional. Interessa-nos aprofundar o olhar no objeto de estudo para então analisá-lo no contexto proposto. Por uma facilidade meramente didática, admitimos duas esferas - uma do simbólico, que seria o feijão enquanto signo de representação, e outra enquanto alimento, que seria sua definição, usos etc. Em partes, estes escritos foram baseados no artigo que foi apresentado na

\footnotetext{
40 FRIEIRO, Eduardo. Feijão, Angu e Couve. São Paulo: Ed. Universidade de São Paulo 1982, p. 56.

41 DÓRIA, Carlos Alberto. "Feijões como patria, locus \& domus no sistema culinário brasileiro". Versão em português de "Beyond Rice Neutrality: Beans as Patria, Locus and Domus in the Brazilian Culinary Sistem", texto publicado originalmente em WILK, Richard e BARBOSA, Livia (orgs), Rice and Beans. A unique dish in a hundred places, NY, Berg, 2012, págs. 121 a 135. p. 121.
} 
ANPUH 2013 com o título - "Diálogos sobre o feijão - a construção da imagem da cozinha brasileira dentro do contexto Modernista".

Antes de entrarmos no período que foi proposto para esta pesquisa, vimos a necessidade de analisar nosso objeto de estudo e a formação do seu imaginário. Precisamos entender como havia se formado o que chamamos de "mito nacional do feijão", ou seja, compreender como esse alimento se tornou signo de brasilidade e parte do discurso da cozinha brasileira. Após essa análise, pretendemos abordar como ele é consumido entre os anos 1973 e 2009.

\subsection{0 alimento dos pobres}

Sabemos que $O$ ato de comer determina e escancara as regras de identidade e hierarquias sociais ${ }^{42}$. A ligação entre identidade e consumo faz com que a refeição e o alimento tenham um papel de destaque na formatação da comunidade, nas mensagens que passamos enquanto grupo ou indivíduo. No caso do feijão, isso se torna bem evidente e é especialmente importante no debate de diferenciação de hábitos de distintas classes sociais, já que ele apresenta o que a economia chama de demanda de elasticidade negativa ${ }^{43}$, ou seja, quanto maior a renda, menor tende ser o seu consumo. Uma das hipóteses para essa característica é que o feijão, historicamente - e de forma geral as leguminosas - é um alimento base para alimentação. Por sua grande capacidade de nutrir e fornecer proteínas a um baixo custo da produção, tem alimentado muitas gerações de famintos. Ele se torna um substituto das fontes

\footnotetext{
42 CARNEIRO, Henrique. "Comida e Sociedade: significados sociais na história da alimentação". In: Questões \& Debates, Curitiba, n.42, 2005. p. 71-80.

43 O conceito econômico de elasticidade renda-demanda calcula, segundo a renda real do consumidor, a variação da demanda de um produto. Portanto, elasticidade negativa é quando a demanda de um produto cai se a renda do consumidor aumenta, sendo assim chamado bem inferior, por exemplo, carne de segunda. A elasticidade-renda do feijão é de 0,0042, o que quer dizer que quando a renda aumenta $10 \%$, a demanda diminui 0,42\%. In: HOFFMANN, Rodolfo. "Elasticidade-renda das despesas com alimentos em regiões metropolitanas do Brasil em 1995-86. Informações Econômicas, v30, n.2, p. 17-24, fev. 2000.
} 
de proteína animal, mais custosas e que, historicamente, estiveram presentes nas mesas mais abastadas.

O feijão, além de ser a comida do cotidiano, é o legume mais importante da Europa e das Américas ${ }^{44}$. Aquele que sempre esteve presente na ausência de outros alimentos, acabava por representar também as ausências, as poucas possibilidades e a pobreza. Esta não parece ser uma especificidade brasileira. Thomas Wyatt escreve, em meados do século XVI, um poema sobre um rato que vive em um esgoto ${ }^{45}$ :

She must lie cold and wet in sorry plight,

And worse than that, bare meat there did remain

To comfort her when she her house had dight -

Sometime a barley corn, sometime a bean,

For wich she labored hard both day and night ${ }^{46}$

O quadro $O$ comedor de feijões, de Annibale Carrache, mostra uma cena de 1583 de um camponês com mãos grossas que tem à mesa feijões, pão e cebolas. O vidro da janela está quebrado, por onde entra um pouco de luz e seu chapéu gasto denuncia sua condição social:

${ }^{44}$ FELIPPE, GIl. Grãos e sementes - a vida encapsulada. São Paulo: Senac, 2007. p. 252.

45 ALBALA, Ken, Beans, a History. Oxford, New York: Berg 2007. p. 22.

46 Tradução livre: Ela se deita fria e úmida num estado lastimável / e pior que isso, com o corpo nú assim permaneceu / para confortá-la, quando a casa dela estava enfeitada / algumas vezes milho e cevada, outras o feijão / para o qual ela trabalhou duro dia e noite. 


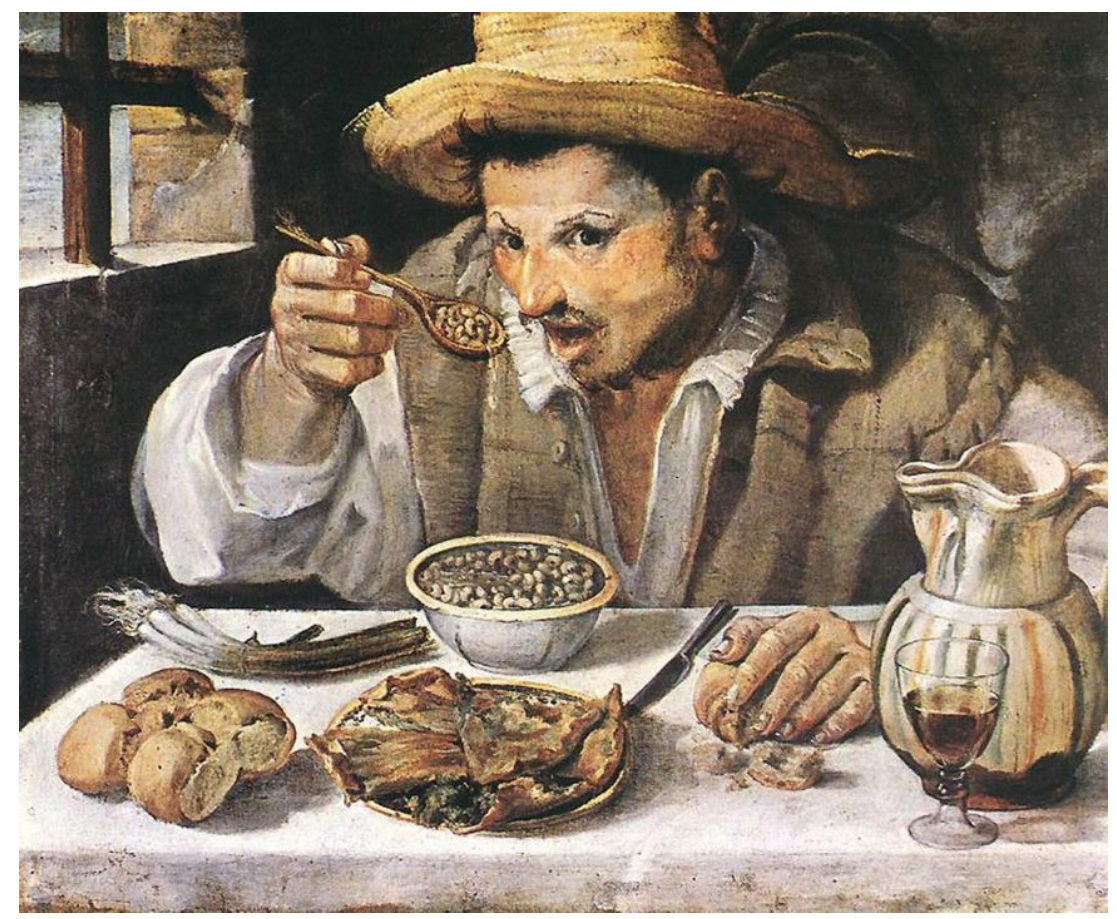

Figura 01: O comedor de feijões, Annibale Carrache. 1583

Porém, para alguns, quando o feijão - na realidade, uma nova espécie botânica que levou o nome feijão por se assemelhar com a leguminosa já conhecida - foi encontrado na América e introduzido na Europa, não passava de uma iguaria. Verde, era muito procurado pela burguesia. No permanente desejo de distinção daqueles que tinham acesso aos novos produtos, exclusivos, o feijão verde se tornou um legume procurado, como mostra Marcel Proust em A prisioneira 47 :

E pensar que vamos ter de esperar mais dois meses para ouvirmos: 'Feijões verdes e tenros feijões, olha o feijão verde'. Como a palavra está bem empregada: tenros feijões! Você sabe que gosto deles bem finos, muito finos, reluzentes de vinagrete; não se diria que são para comer, eles são frescos como o orvalho

Apesar dessa exceção, a imagem do feijão como alimento daqueles que nada possuem perpassa as barreiras do espaço e do tempo. Em Tortilla Flat, John Steinbeck recorda que na Califórnia, região de Monterey, "os feijões são

47 Apud: BLOCH-DANO, Évelyne. A fabulosa história dos legumes. São Paulo: Estação Liberdade, 2011. p. 151. 
um abrigo protetor para o estômago, um casaco quente contra as intempéries econômicas" 48 .

Assim como no poema e no quadro, outros alimentos básicos para a alimentação do brasileiro -mandioca ou milho, por exemplo-, além de serem rotulados como pertencentes às camadas mais baixas, não contam com campanhas milionárias nem com o apelo das cores e dos brinquedos de brinde, por isso são cada vez menos lembrados na hora das refeições. "O feijão é um marcador da prática de comer com garfo e faca, na companhia de outras pessoas e sem dividir tempo com outra tarefa, como dirigir ou ver TV"49.

Se analisarmos o consumo por renda, veremos que ele é maior nas classes mais baixas e varia muito de região para região. Por exemplo, a Pesquisa de Orçamentos Familiares (POF) do Instituto Brasileiro de Geografia e Estatística (IBGE) de 2002 aponta que a média de consumo anual per capita de feijões ${ }^{50}$ no Brasil é de 12,394 kg. Nos estratos inferiores esse consumo vai para 14,612 kg, enquanto nas mais altas cai para $10,482 \mathrm{~kg}^{51}$. Ou seja, uma diferença de $28 \%$. Um dado chama atenção: com o feijão-jalo acontece o oposto - ele é primordialmente consumido pelas altas classes. Enquanto a classe com renda acima de três mil reais $(R \$ 3.000,00)$ consome $1,403 \mathrm{Kg}$, os que ganham menos de quatrocentos reais $(R \$ 400,00)$ consomem $0,314 \mathrm{Kg}$. Este seria o feijão dos ricos? Já com o feijão-fradinho a diferença é enorme. A classe mais alta consome $0,391 \mathrm{~kg}$; e os mais pobres, $3,643 \mathrm{~kg}$ - quase dez vezes mais. Podemos notar, portanto, que excetuando alguns momentos o feijão mantém sua demanda de elasticidade negativa, carregando a imagem de alimento da fome.

\footnotetext{
48 Idem, ibidem. p. 143.

49 MONTEIRO, Carlos Augusto. "Feijão, comida rápida e obesidade". Folha de São Paulo. 13 de junho de 2007. 2010, Primeiro Caderno, A3. Disponível em: http://acervo.folha.com.br/fsp/2010/6/13/2

50 Para esta consulta somamos os tipos de feijões que a POF optou por apresentar separado são eles: feijão-fradinho, feijão-jalo, feijão-manteiga, feijão-mulatinho, feijão-preto, feijão-rajado, feijão-roxo e outros feijões.

51 IBGE. Pesquisa de Orçamentos Familiares 2002. Rio de Janeiro, 2004.
} 


\subsection{Feijão, o alimento da nação}

"Esse lugar comum consolidado, segundo o qual a 'cozinha de território' seria uma realidade antiquíssima, nativa, atávica, é um equívoco sobre o qual é oportuno refletir atentamente." $52 \mathrm{Em}$ diferentes momentos históricos e nas várias formas de representação do que seria o Brasil e do que este povo que aqui habitava se alimentava, o feijão aparece como alimento frequente à mesa. Para compreender a imagem que ele carrega enquanto síntese da nação, temos de entender o processo e os debates que envolvem esse tema no Brasil.

Em 1822, quando a independência foi decretada, o que havia no território português da América eram regiões desconexas que estavam começando a se agregar em torno do Rio de Janeiro depois da vinda da corte em 1808. Até a mudança para essa cidade, dentro do modo de colonização portuguesa, cada região respondia para a metrópole, não criando um polo centralizador nessas terras. Assim, a transferência da capital para além-mar foi fundamental para a manutenção da unidade territorial, mas não criou uma imagem unitária. Aqui assumimos que essa unidade territorial não tem a ver com o processo passivo que uma parte da historiografia por um tempo adotou. O processo das terras luso-americanas não é o contraponto do que ocorreu no território hispânico e também foi passível de conflitos. Entendemos que a centralização prévia com a vinda da corte foi condição importante para a manutenção posterior do território, mas não ausente de conflitos. Quando a independência aconteceu, enquanto evento político, não havia no recém-criado Brasil uma unidade cultural construída que pudesse ser identificada. Assim, a colonização, que em si já era a comunhão das variadas culturas, inclusive as que habitavam previamente as terras portuguesas, não foi a resposta encontrada para o necessário respaldo que o Estado precisava para se legitimar enquanto nação.

O surgimento dos Estados-nações ganhou fôlego no século XIX, principalmente na Europa Ocidental. Ali, criou-se o mito de que os diferentes

\footnotetext{
52 MONTANARI, Massimo. Comida como cultura. São Paulo: Senac, 2008. p. 135.
} 
países sempre foram distintas e estáveis unidades que eram facilmente identificáveis por sua língua, religião, costumes e imagem nacional que de forma alguma era mutável ${ }^{53}$. Assim escreve Benedict Anderson: "os Estadosnações de base étnica nos dias de hoje foram descritos como 'comunidades imaginadas', geradas pelos esforços criativos dos intelectuais e políticos do $\mathrm{XIX}$, que transformaram antigas tradições românticas e nacionalistas em programas políticos". ${ }^{54}$ Até mesmo o termo nação, no sentido moderno da palavra, vem do século XVIII55.

Esses estudiosos, intelectuais e políticos não "criaram" uma imagem de nação sem partir de algo palpável. Eles pesquisaram e se basearam em fontes, tradições e crenças transmitidas pela oralidade, mesmo que imaginadas. "Os símbolos são eficientes quando se afirmam no interior de uma lógica comunitária efetiva de sentidos"56. Mesmo sendo impossível definir ${ }^{57}$ objetivamente uma lógica precisa. "Na verdade, como poderia ser diferente, já que estamos tentando ajustar etnicidades historicamente novas, emergentes, mutáveis e, ainda hoje, longe de serem universais em um quadro de referências dotado de permanências e universalidade?"58 Para o autor Patrick Geary essa apropriação para a formação da carcaça nacional passa por três estágios: o primeiro é o estudo da língua, cultura e história de um povo por um grupo de intelectuais, depois a transmissão das ideias dos acadêmicos por um grupo de "patriotas" que as divulgam; por último, o movimento nacional atinge seu apogeu, ganhando a sociedade ${ }^{59}$. Mesmo que sem essa clara linearidade, podemos observar esse fenômeno nas Américas do século XX, inclusive no Brasil.

53 GEARY, Patrick J. O mito das nações: a invenção do nacionalismo. São Paulo: Conrad Editora do Brasil, 2005. p. 22.

${ }^{54}$ ANDERSON, Benedict. Comunidades imaginadas. Reflexões sobre a Origem e a Expansão do Nacionalismo. Lisboa: Edições 70, 2005. p. 71.

55 HOBSBAWM, Eric J. Nações e Nacionalismos desde 1780. Rio de Janeiro: Paz e Terra, 1990. p. 13.

56 ANDERSON, Benedict. Op. Cit. p. 16.

57 Por esta dificuldade adotamos a visão de Hobsbawn que "nação é qualquer corpo de pessoas suficientemente grande cujos membros consideram-se como membros de uma "nação"' In:HOBSBAWM, Eric J. Nações e Nacionalismos... Op. Cit. p. 18.

58 HOBSBAWM, Eric J. Nações e Nacionalismos... Op Cit, p. 15.

59 GEARY, Patrick. Op. Cit. p. 30. 
Assim como ocorreu com várias nações do mundo ocidental, a necessidade de construir essa tradição partilhada por todos acabou muitas vezes passando por cima da diversidade das culturas e etnias que ocupavam o território brasileiro. Naquela época, a construção do estado brasileiro passava também pelo dilema de rompimento com a Europa colonizadora, com os moldes europeus. Manteríamos nossa ligação com o passado colonial ibérico ou construiríamos uma nação orientada por um novo modelo? A partir de um contexto maior de definições dos Estados Nacionais, o Brasil, na forma de política pública ou através da sua produção artística, buscou criar e ressaltar a unidade nacional legítima e única. Importante marco neste processo foi a criação, em 1838, do Instituto Histórico Geográfico Brasileiro, o IHGB, que queria entender, através de seu primeiro concurso, a seguinte questão: Como escrever a História do Brasil?

O vencedor deste concurso, Karl Von Martius, escreveu que a História do Brasil precisava ser contada através da miscigenação, "que nossa história era na realidade miscigenada: 'devia ser um ponto capital para o historiador reflexivo mostrar como no desenvolvimento sucessivo do Brasil se acham estabelecidas as condições para o aperfeiçoamento das três raças humanas (...)"'60. Com isso, o mito das três raças estaria presente e transitaria por uma grande parte dos estudos e formulações sobre a história, costumes, formação e identidade brasileira. Essa visão atravessou as várias tendências de pensamento da época, passando pelos naturalistas, racistas e pessimistas do século XIX, até chegar aos culturalistas, otimistas da primeira metade do século $X X$.

Os viajantes foram importantes atores no registro dos hábitos dessas terras durante o período colonial e mesmo no século XIX e XX e portanto fundamentais na construção da imagem nacional. Os seus relatos são fontes preciosas para entendermos quais eram as disponibilidades e como se comportavam os habitantes da América portuguesa e depois Brasil. Neles se inspiraram muitos autores para aquilo que foi produzido posteriormente. Em

60 SCHWARCZ, Lilia Katri Moritz. "Complexo de Zé Carioca. Notas sobre uma identidade mestiça e malandra". In: Revista Brasileira de Ciências Sociais, n. 29, 1995, p 43-69. p. 47. 
seus textos e gravuras podemos usualmente encontrar feijão, ainda que essas obras apareçam distribuídas de forma distinta no tempo.

Quando usamos os viajantes como fonte, precisamos ter em mente duas observações: a primeira é que eles eram europeus que registravam o cotidiano em terras estranhas. Isso já Ihes conferia um olhar eurocêntrico em relação ao que acontecia por aqui. Em segundo lugar, o que mais Ihes interessava era o exótico, ou seja, aquilo que remetia ao próprio cotidiano não era tão digno de nota quanto o que era novo. Mesmo assim, esses estudos continuam sendo importantes documentos para análise dos hábitos e cotidiano do período colonial.

Na compilação feita pelo Museu da Casa Brasileira, o Arquivo Ernani Silva Bueno ${ }^{61}$ elenca duzentas e trinta e quatro citações com feijão. São relatos de viagem, inventários e registros que vem desde o século XVI. Para entendermos quais as variadas formas de usos do mantimento, fizemos um exercício de separar os registros por século. E encontramos números interessantes. Neste primeiro século, XVI, achamos apenas um documento que, na verdade, é mais um exemplo para falar de outro alimento que parece ser uma manona: "Esta erva dá o fruto em cachos cheios de bagos, tamanhos como avelãs, todos cheios de bicos; cada um destes bagos tem dentro um grão pardo, tamanho como um feijão, o qual pisado se desfaz todo em azeite, que serve na candeia [...]" (grifo nosso) ${ }^{62}$.

No século XVII este número vai para seis citações, sendo que dois são inventários e quatro do livro de Johann Nieuhof. No Memorável Viagem Marítima e Terrestre ao Brasil (1640-1649). O autor faz uma descrição do que seria uma refeição: "Apanham a farinha de mandioca com três dedos da mão direita e atiram-na para dentro da boca. O mesmo o fazem com feijão e outros alimentos semelhantes" (grifo nosso) ${ }^{63}$.

\footnotetext{
61 Disponível em: http://www.mcb.org.br/ernMain.asp acessado em 30/07/2013.

62 SOUSA, Gabriel Soares de. Tratado Descritivo do Brasil (1587). São Paulo, EDUSP/ Companhia Editorial Nacional, 1971. p. 206.

63 NIEUHOF, Johann. Memorável Viagem Marítima e Terrestre ao Brasil (1640-1649). São Paulo, Martins Editora, 1942. p. 303.
} 
No século XVIII apenas duas citações com feijão -um inventário e uma descrição sobre o cotidiano de Salvador (grifo nosso) ${ }^{64}$ :

Não deixa de ser digno de reparo o ver que das casas mais opulentas desta cidade [...] saem oito, dez e mais negros a vender pelas ruas [...] iguarias de diversas qualidades v.g. mocotós, isto é, mãos de vaca, carurus, vatapás, mingaus, pamonhas, canjicas; isto é, papas de milho, acaçás, acarajés, abarás, arroz de coco, feijão de coco, angus, pão-de-ló de arroz, o mesmo de milho, roletes de cana, queimados, isto é, rebuçados a 8 por um vintém, e doces de infinitas qualidades [...] e o que mais escandaliza é uma água suja feita com mel e certas misturas a que chamam o aluá que faz vezes de limonada para os negros.

Ao passo que no Século XIX encontramos duzentas e vinte e uma citações sobre feijão. São inventários, descrições de viajantes e literatura. Sobre a viagem ao Amazonas, nos conta Bates (grifo nosso) ${ }^{65}$ :

Pouco antes do jantar costumávamos tomar banho no rio e então, seguindo o costume universal, no Amazonas, onde parece aconselhável, por causa da alimentação fraca de peixe, cada qual tomava meia xícara de cachaça, o abre, como eles chamam, e fazíamos nossa refeição de pirarucú cozido, feijão e toucinho. Uma ou duas vezes por semana tínhamos galinha com arroz. $\mathrm{Na}$ ceia, depois do pôr do sol, tínhamos às vezes, peixe fresco, pescado por nossos homens à tarde.

Oscar fala sobre a alimentação do Sul (grifo nosso) ${ }^{66}$ :

Nas províncias do sul cultiva-se de preferência o sorgo ou milho em grande escala, sendo consumido por homens e animais. Ao lado do milho cultivam também o feijão preto (Phaseolus derasus) que juntamente com a carne seca, farinha ou milho, constituem na maior parte do Brasil a dieta diária da população.

64 VILHENA, Luiz dos Santos. Cartas de Vilhena. Notícias Soteropolitanas e Brasílicas (1802). vol. I, Salvador, Imprensa Oficial da Bahia, 1922. p. 131.

65 BATES, Henry Walter. O Naturalista no Rio Amazonas (1848-1859). vol. I, São Paulo, Companhia Editora Nacional, 1944. p. 299-300.

66 CANSTATT, Oscar. Brasil, a Terra e a Gente (1868). Rio de Janeiro, Irmãos Pengetti Editores, 1954. p. 102. 


\begin{abstract}
E referindo-se a uma estadia na fazenda de Minas Gerais (grifo nosso) $)^{67}$ :
\end{abstract}

No entretanto, o dono da casa esperava-nos na varanda com os seus, e uma profusão de iguarias cobrindo uma mesa. Tudo o que a arte culinária podia apresentar além do abundante trivial, estava como é costume nas fazendas, na mesa e podia-se ficar seriamente embaraçado na escolha do prato de que se devia servir primeiro como se poderia evitar que qualquer iguaria, antes de chegar sua vez, esfriasse e ficasse intragável. Sentia-se o aroma da inevitável feijoada com charque, galinha com arroz e guisado tudo ao mesmo tempo. Na previsão de que durante a viagem ia ficar farto de feijão, estendi a mão para a grande terrina de galinha com arroz.

O aumento substancial não quer dizer diretamente que antes do XIX os habitantes quase não se alimentavam de feijão. Temos de ter em mente que a produção literária e os registros escritos aumentaram muito, e a produção foi particularmente intensa no século XIX, com o Romantismo e a intensificação das expedições a partir da vinda da corte. Podemos supor um possível aumento do consumo, mas principalmente 0 aumento das representações sobre esse consumo -e o feijão tem um importante papel nesses registros.

Optamos, então, por comparar a leguminosa com a presença de outras palavras que fazem parte do mesmo repertório, como "carne", por exemplo. Encontramos cinquenta e seis (56) citações no século XVI, quarenta e nove (49) no século XVII, dezesseis (16) no século XVIII e quatrocentas e trinta e um (431) no século XIX. Para "milho", onze citações (11) no século XVI e setenta e sete (77) no século XVII, quinze (15) no XVIII e duzentos e setenta e sete (277) no XIX.

Entendemos, assim, que se falava proporcionalmente mais de milho e carne do que de feijão. Porém, no último século houve um aumento

\footnotetext{
${ }^{67}$ Idem, Ibidem. p. 330-1.
} 
relativamente substancial deste. Seria o aumento do consumo? O que esses números nos mostram é que se falava muito pouco de feijão antes do século XIX. Mesmo se levarmos em consideração que a produção de registros sobre hábitos fosse menor que nos séculos subsequentes, parece-nos que não apenas o registro ganhou espaço, mas o feijão neste registro. A leitura apenas desse cenário não nos permite afirmar isso categoricamente. $O$ que podemos assegurar, no entanto, é, no mínimo, o aumento do apontamento de forma geral e o crescimento dos relatos sobre os usos do feijão. A observação de Paula Pinto e Silva sobre a similaridade do feijão com a alimentação europeia nos auxilia no entendimento ${ }^{68}$ :

transplantadas para uma terra distante, dividindo espaços com escravas negras e indígenas, privadas de produtos dos quais estavam acostumadas, as senhoras portuguesas se viram obrigadas a reinventar práticas e costumes tradicionais do Reino, transformando suas novas casas e seus hábitos mais íntimos para adequá-los às exigências da nova vida.

Este alimento foi paulatinamente ganhando espaço na mesa, pois a possibilidade de fazer comida com caldo fez com que ele tivesse um lugar cativo na refeição. Os relatos do século XIX mostram o crescimento dessa importância. Antes, o feijão não figurava entre os alimentos que eram incentivados pelo controle governamental. "A dieta fundamental compunha-se apenas, na época, de farinha de mandioca seca, carne-seca, peixe-seco ou carnes e peixes salgados (...)"69

Entendemos, então, porque autores como Câmara Cascudo, Carlos Alberto Dória e Paula Pinto e Silva, mesmo destacando o consumo que o feijão tinha no período colonial, reforçam o crescimento em importância do mesmo enquanto ideal de brasilidade em um momento posterior. "Os feijões (...) não eram indicados na habitualidade do repasto indígena como significam contemporaneamente na refeição brasileira. Foram, entretanto, cultivados,

\footnotetext{
68 SILVA, Paula Pinto e. Op. Cit. p. 39.

69 PAPAVERO, Claude. "Dos feijões à feijoada: a transformação de um gênero comestível pouco apreciado em mantimento básico brasileiro". Trabalho apresentado na $26^{\circ}$ Reunião Brasileira de Antropologia realizada entre os dias 01 e 04 de junho de 2008 em Porto Seguro, Brasil.
} 
índice de reserva cuidadosa."70 Cascudo nos dá outra informação importante. Alimento nativo da América e conhecido dos que aqui habitavam antes da colonização, o feijão não era amplamente consumido como alimento central da dieta. Ao contrário, era cultivado "em pequena escala em roças intermediárias feitas logo após a colheita de milho ou acompanhando algum outro produto de subsistência, como a batata-doce. ${ }^{71} \mathrm{O}$ autor acrescenta ${ }^{72}$ :

Pela documentária dos séculos XVI e XVII o feijão não acusa saliência nem posto na atenção administrativa. Toda legislação oficial que conhecemos nesses duzentos anos e mais, afasta o feijão dos cuidados defensivos, mantidos para o açúcar, moeda internacional, farinha de mandioca e milho, alimento natural das bocas curibocas, mamelucas e mulatas.

Apesar de nos contar que o feijão ganha espaço na primeira metade do século XVII, um pouco prematuro ao nosso ver e também na opinião de Claude Papavero, Cascudo já aponta que ele teve uma adoção tardia ${ }^{73}$. Claude nos apresenta o testemunho de Gabriel Soares de Sousa, que, em sua viagem para a Espanha, escreve um tratado sobre produtos e modo de vida na colônia. Falando sobre os legumes chamados de indígenas comenta ${ }^{74}$ :

Há outras favas, meio brancas e meio pretas, mas são pequenas; e estas favas se plantam à mão na entrada do inverno [...]; começam a dar a novidade no fim do inverno e dura mais de três meses. Estas favas são, em verdes, mui saborosas, e cozem-se com as cerimônias que se costumam em Portugal, e são reimosas como as do reino; e dão em cada bainha quatro a cinco favas, e depois de secas se cozem muito bem, e não criam bichos, como as da Espanha, e são muito melhores de cozer; e de uma maneira e de outra fazem muita vantagem no sabor às de Portugal, assim as declaradas como a outra casta de favas que são brancas e pintadas de ponto negro.

70 CASCUDO, Luis Câmara. História da Alimentação no Brasil. São Paulo: Global, 2011. p. 155.

71 SILVA, Paula Pinto e. Op. Cit. p. 115.

${ }^{72}$ CASCUDO, Luis Câmara. Op. Cit. p. 497.

73 PAPAVERO, Claude. Op. Cit. p. 2.

${ }^{74}$ SOARES, Gabriel Soares de. Op. Cit. p. 183. Apud: PAPAVERO, Claude. Op. Cit. p. 3. 
Se por um lado temos poucas pistas sobre o aumento do consumo dessa leguminosa, por outra podemos encontrar algumas justificativas para sua baixa ingestão. Entre elas, seu desprestígio social pelo fato de ser consumido como alimento substituto por aqueles que não tinham poder aquisitivo para comer carne, por causar flatulência, por ser desaconselhado pelos médicos e ainda conhecido por mudar os humores. ${ }^{75}$

"A superação das relutâncias prévias dos colonos em relação à ingestão de feijões e sua transformação em mantimento básico da dieta alimentar brasileira foi um fenômeno que parece ter se desenrolado no plano das considerações pragmáticas, entre a segunda metade do século XVII e os primórdios do século XVIII." ${ }^{" 6}$ Além de ser uma das formas de tornar a comida úmida, era importante para o deslocamento que os bandeirantes antes já praticavam -entre outros motivos, seu breve ciclo para colheita. A ocupação do interior brasileiro e o desenvolvimento da economia aurífera fizeram com que estes hábitos, meio indígenas, meio desbravadores, ganhassem mais espaço.

Assim, o feijão, que era acessível, foi se transformando em um item indispensável. $\mathrm{Na}$ longa duração do período colonial, com o aumento da facilidade de acesso a alimentos e a troca cultural de técnicas, houve a paulatina absorção de certos alimentos nas dietas ${ }^{77}$.

Pode-se dizer que o longo período colonial foi de integração mundial dos ingredientes culinários, graças às dimensões globalizadas do sistema econômico montado pelos portugueses. Foi também um período de assimilação das técnicas culinárias europeias no mundo extra europeu, deixando em segundo plano as técnicas indígenas.

Podemos, então, confirmar que houve gradualmente o crescimento do feijão como elemento da dieta e facilitador da interiorização, se tornando,

\footnotetext{
75 PAPAVERO, Claude. Op. Cit. p. 12.

76 Idem, ibidem. p. 13.

77 DÓRIA, Carlos Alberto. Formação culinária brasileira. São Paulo: Publifolha, 2009. p. 43.
} 
assim, um elemento fundamental nesse momento. "Atrás dos colonos foi o feijão"78.

Dentro desse movimento maior da criação da ideologia chamada Brasil, o feijão assumiu um papel central de alimento da nação. E esse papel teve seu coroamento na primeira metade do século XX. Esse período corresponde à produção que chamamos modernista, na realidade o debate em torno do modernismo que envolvia diversos atores, estes e outros que tinham discurso contrário. O feijão aparecia frequentemente nos escritos sobre os costumes populares dentro das produções, nos retratos do Brasil. "Pois é apenas a partir do Modernismo brasileiro nos anos 1920 que o discurso sobre o feijão se estrutura, fazendo dele um dos pilares do mito da nacionalidade tripartite do Brasil -a miscigenação dos índios, negros e brancos."79

O segundo momento, no qual os estudiosos, escritores e artistas pensaram o Brasil de forma mais otimista, quando a miscigenação passou a ser vista como uma vantagem, é o que mais nos interessa nesta perspectiva. A partir daí podemos notar um aumento da valorização ${ }^{80}$, pelo menos nos textos, do que era produto desta terra, ainda que o consumo das elites fosse de influência externa, à francesa.

Antônio Cândido, na obra Literatura e sociedade, analisa o Modernismo, que ele enquadra entre 1922 e 1945. O autor nos explica que foi neste período que uma nova proposta de interpretação foi dada, pois o que antes escondíamos, o que antes nos era um fardo, era agora superioridade: "Tudo aqui é belo e risonho: acentuam-se a rudeza, os perigos, os obstáculos da natureza tropical. O mulato e o negro são definitivamente incorporados como tema de estudo, inspiração e exemplo." ${ }^{11}$ Assumimos que a imagem nacional é essencialmente proposta, pois não há como admitir como únicos os hábitos de um território político, principalmente em um país de dimensões continentais

\footnotetext{
${ }_{78}$ ELIAS, Rodrigo. "Breve história da feijoada”. In: Nossa História, ano 01. oㅡ 04, fev de 2004. 79 DÓRIA, Carlos Alberto. "Feijões como patria, locus \& domus ... Op. Cit. p. 01.

80 Por mais que os românticos ou acadêmicos entoassem um hino em prol do nacional, os personagens eram construídos e idealizados a partir de moldes europeus, sem grandes pesquisas de campo. Podemos encontrar algumas exceções que se destacam, como JeanBaptiste Debret e sua importante contribuição para a iconografia.

81 CANDIDO, Antônio. Literatura e Sociedade. Rio de Janeiro: Ouro sobre Azul, 2006. p. 127.
} 
como o Brasil. Dessa forma, o projeto que começou no século XIX ganhou corpo na primeira metade do século XX.

Entendemos esse momento como uma circulação de ideias de forma ampla. Muitos desses atores estavam interessados em formar uma imagem de Brasil -ou de partes dele. Dentro dessa produção, elegemos quatro grandes expoentes no que tange a retratos da alimentação, sem deixar, contudo, de mencionar outros. São estes: Monteiro Lobato, Mário de Andrade, Luis da Câmara Cascudo e Gilberto Freyre. Admitimos que houvesse uma intensa circulação de ideias entre eles, mesmo que os estudos posteriores os colocassem em compartimentações distintas. O primeiro, Monteiro Lobato, foi designado como pré-modernista ou regionalista, por retratar principalmente 0 Vale do Paraíba e, apesar de buscar os costumes populares, os críticos não o atribuem um rompimento estético ${ }^{82}$. Sua polêmica com a vanguarda do movimento modernista é amplamente conhecida e pode ser ilustrada nesta crítica à Anita Malfatti83:

Há duas espécies de artistas. Uma composta dos que vêem normalmente as coisas e em consequência disso fazem arte pura, guardando os eternos ritmos da vida, e adotados para a concretização das emoções estéticas, os processos clássicos dos grandes mestres. (...). A outra espécie é formada pelos que vêem anormalmente a natureza, e interpretam-na à luz de teorias efêmeras, sob a sugestão estrábica de escolas rebeldes, surgidas cá e lá como furúnculos da cultura excessiva. São produtos do cansaço e do sadismo de todos os períodos de decadência: são frutos de fins de estação, bichados ao nascedouro.

Havia uma intensa troca. Enquanto expoente do modernismo, Mário de Andrade estaria do outro lado do debate, criticando, porém reconhecendo, o

82 PASSIANI, Enio. Na trilha do Jeca, Monteiro Lobato e a formação do campo literário no Brasil. Bauru: EDUSC, 2003. p. 20.

83 LOBATO, Monteiro. "Paranóia ou mistificação: a propósito da exposição Malfatti". O Estado de São Paulo. 20 de dezembro de 1917. 
papel de Lobato. Em uma das cartas que Mário de Andrade trocava com Câmara Cascudo, o primeiro escreve ${ }^{84}$ :

Não se amole muito com a chuçada que dei no Lobato. Ele estava carecendo por causa de um artigo besta que escreveu sobre nós. Nem por isso deixo de reconhecer o valor dele embora também reconheça e com raiva que ele não está fazendo valer bem o e a influência que tem.

A amizade de Mário de Andrade e Luís da Câmara Cascudo é conhecida e bem documentada em correspondências ${ }^{85}$. Parte delas estão, por exemplo, no livro de Marcos Antônio de Moraes, Câmara Cascudo e Mário de Andrade - cartas 1924-194486. Mário estava interessado em mostrar um Brasil sem separação regional. Sobre o livro Macunaíma ele conta: "um dos meus cuidados foi tirar a geografia do livro. Misturei completamente o Brasil inteirinho como tem sido minha preocupação desde que intentei me abrasileirar e trabalhar o material brasileiro." 87 Houve uma grande influência da produção de Mário na obra de Cascudo. Não apenas, mas também por isso, os estudiosos consideram este mais modernista do que Gilberto Freyre, regionalista. A preocupação de Cascudo era, mesmo que a partir de uma grande obra potiguar, falar do Brasil unitário.

Além do "Jeca Lobato", como Mário de Andrade às vezes falava, outros tantos estavam nas cartas entre este e Câmara Cascudo -as ideias estavam no ar: Oswald de Andrade, Manuel Bandeira e Gilberto Freyre, por exemplo. Este último, nos conta Marcos Moraes em uma nota de rodapé na compilação das cartas, mandou uma correspondência a Luís da Câmara Cascudo sobre um livro que este publicara ${ }^{88}$ :

\footnotetext{
84 MORAES, Marcos Antonio de (org.). Câmara Cascudo e Mário de Andrade: cartas, 19241944. São Paulo: Global, 2010. p. 114.

${ }^{85}$ Fonte importante que não será abordada é a compilação de cartas de Luis Câmara Cascudo feita pelo Instituto Câmara Cascudo localizada em Natal, Rio Grande do Norte. Lá estão agora vinte e sete mil correspondências que o pensador trocou durante sua vida e agora serão digitalizadas.

${ }^{86}$ MORAES, Marco Antonio de. Op. Cit.

87 Idem, ibidem. p. 11.

88 Idem, lidem. p. 80.
} 
Há umas boas páginas mas no conjunto me parece um livro apressado que não justifica o subtítulo Literatura e crítica. É antes, jornalismo feito em livro. Prefiro as Histórias onde há páginas interessantes como aquela sobre a morte do holandês. Acho que a sua veia é antes história do que crítica. É por isso que espero um trabalho sugestivo sobre estes cem anos de vida de Natal. Não estranhará $V$. a franqueza - sabendo que sem ela eu não sou eu.

Porém, em vez de enquadrá-los neste ou naquele movimento, preferimos pensar que existia uma intensa circulação de ideias e um foco predominante em produzir a imagem brasileira. O próprio Mário de Andrade, protagonista do período, escreve em 1943: "Manifestado especialmente pela arte, mas manchando também com violência os costumes sociais e políticos, o movimento modernista foi o prenunciador, o preparador e por muitas vezes o criador de um estado de espírito nacional." 89.

A semana de arte de 1922 e os artistas que estavam ao seu redor pretendiam romper com o que determinavam como padrões ultrapassados e formatar uma nova linguagem para constituir a "verdadeira arte brasileira". Neste contexto muito se debateu sobre o que era essa arte e como ela deveria representar. Essas discussões não estavam fechadas em um único circuito, e o que acontecia por aqui não estava isolado das influências europeias, ao contrário, era também fruto e inspirado por aquilo que se produzia lá. O que se queria entender sobre o Brasil estava ligado, como já mencionamos, a um contexto de afirmação dos Estados nacionais e na política interna ao crescimento, pós proclamação da república, de um ufanismo. E a este cadinho de novas produções podemos incluir os trabalhos de cunho sociológico e historiográfico de autores como Gilberto Freyre e Luís Câmara Cascudo.

O primeiro autor, vindo da temporada nos Estados Unidos e em contato com a mais recente antropologia produzida lá, escreveu em sua vasta obra o coroamento da formação tripartite e pacífica do país na qual negros, índios e brancos davam sua contribuição para a chamada cultura nacional. O tema da

${ }^{89}$ ANDRADE, Mário de. Aspectos da literatura brasileira. Belo Horizonte: Editora Itatiaia, 2002. p. 253. 
alimentação perpassa toda sua obra. Neste sentido, uma produção importante foi "O manifesto regionalista" de 1926 em que o autor afirma que a cozinha foi um dos elementos fundamentais na valorização da cultura.

Neste momento, Gilberto Freyre estava preocupado com as mudanças causadas pela urbanização e industrialização e o desenvolvimento da região Sudeste. Para ele, poderia haver uma descaracterização da cultura nordestina e a diminuição da importância econômica que esta região outrora apresentara.

A alimentação estaria como a ligação entre o passado, a tradição e costumes que estariam se perdendo com o presente, num processo de urbanização e industrialização. Ele divide o país em sete regiões culinárias. As três principais seriam a nordestina, a baiana e a mineira. As menos importantes - o extremo Norte, a fluminense e norte paulista, a região gaúcha e o sertão. Em cada uma dessas regiões podiam-se ver as influências ameríndia, dos africanos e portugueses em proporções diferentes, mas $^{90}$ :

onde parece que essas três influências melhor se equilibraram ou harmonizaram foi na cozinha do Nordeste agrário onde não há nem excesso português como na capital do Brasil nem excesso africano como na Bahia nem quase exclusividade ameríndia como no extremo Norte, porém o equilíbrio. $O$ equilíbrio que Joaquim Nabuco atribuía à própria natureza pernambucana.

Para justificar essa perspectiva, Gilberto Freyre volta ao período colonial e foca seus estudos em torno do sistema de produção da grande fazenda exportadora, principalmente de açúcar. No manifesto, ele narra suas próprias lembranças de um passado idílico sem as contradições próprias do sistema escravista segregador. O português ganha uma imagem de grande explorador, confratenizador que, sempre de forma pacífica e franciscana, está preparado para compartilhar com outros povos seu conhecimento.

Nessa interação, feita dentro e ao redor do sistema de produção da cana de açúcar, formou a sociedade de cunho latifundiário e tropical e sua grande

90 FREYRE, Gilberto. Manifesto regionalista. Comentário: Antônio Dimas (USP). Disponível online em http://www.ufrgs.br/cdrom/freyre/freyre.pdf. Acesso dia 15/07/2013. 
obra sobre o assunto foi Casa Grande e Senzala. Para Leila Algranti, o autor enfatiza a capacidade dos portugueses de se adaptar às novas condições, aclimatando os hábitos ${ }^{91}$. No que tange à alimentação, esse processo foi particularmente visível, pois na ausência de ingredientes os portugueses tiveram de descobrir outras formas de se alimentar, muitas vezes olhando para aqueles que já habitavam estas terras ${ }^{92}$.

O tema dos hábitos alimentares pode ser visto em toda a obra. A ressalva que Gilberto Freyre faz quanto ao modelo colonial está circunscrita à monocultura que empobrece o solo e a alimentação, deixando de lado a produção de subsistência e a policultura. Sem focar nas questões de condição de escravo e hierarquia social, Freyre escreve que a maior contribuição foi a do negro ${ }^{93}$ :

A influência mais salutar tem sido a do africano: quer através dos valiosos alimentos, principalmente vegetais, que por seu intermédio vieram da África, quer através do seu regime alimentar, melhor e mais equilibrado que o branco - pelo menos aqui, durante a escravidão.

E assim, todos, mesmo que em um sistema de monocultura exportador, não passavam por extremas necessidades, por mais que não houvesse abundância ${ }^{94}$ :

A alimentação do negro nos engenhos brasileiros podia não ser nenhum primor de culinária; mas faltar nunca faltava. E sua abundância de milho, toucinho e feijão recomenda-a como regime apropriado ao duro esforço exigido do escravo agrícola.

Hoje sabemos que a crítica feita à Freyre foi ter atenuado os conflitos e dificuldades daquele período, dando ao negro uma contribuição tão ativa que

\footnotetext{
91 ALGRANTI, Leila Mezan. "História e cultura da alimentação na América Portuguesa tradição e mudanças (uma análise historiográfica)". I Colóquio de história e cultura da alimentação: saber e sabor - história, comida, identidade, Universidade Federal do Paraná, agosto de 2007. p.4.

92 BASSO, Rafaela. A cultura alimentar paulista: Uma civilização do milho? (1650-1750). Dissertação de Mestrado. IFCH/Unicamp,2012. p 10-11.

93 Idem Ibidem. p. 38.

${ }^{94}$ FREYRE, Gilberto. Casa Grande e Senzala. São Paulo: Global, 2006. p 107.
} 
sua situação de escravo o impossibilitava de dar. Apesar disso, ele foi protagonista em introduzir nas Ciências Sociais o olhar para o cotidiano, uma perspectiva que colocava a alimentação dentro da ótica das ciências humanas. De certo, aos escravos pouco restava, menos ainda que a alimentação deficitária dos senhores. "O negro na América, reduzido à condição de coisa, antes de ser artífice de um estilo de comer, será alimentado segundo a diretriz do custo de sua alimentação (...). O que marca a dinâmica alimentar colonial é a fome, não o cenário idílico (...)"95. Tanto que Thomas Davatz, falando sobre sua condição de colono em uma fazenda nos arredores de Limeira escreve ${ }^{96}$ :

Como é possível ao colono 'obter por si só aquilo de que necessite' [...]? Ou supõe-se porventura que os colonos conseguirão apreciar o milho, o arroz e o feijão sem tempero algum, como sucede com os escravos negros?

O colono está nos falando que o negro recebia muito pouco; e eles, enquanto colonos, não se adaptariam a esta alimentação deficiente do escravo. Da mesma forma, Alcides D'Orbigny escreve sobre a alimentação dos escravos na extração de diamante em $1832^{97}$ :

A alimentação dos escravos consiste em angu de fubá, farinha de mandioca e feijão. Recebem, além disso, um pouco de sal e um pedaço de fumo de rolo.

Como podemos ver nas duas citações, não nos parece que havia diversidade ou fartura, nem mesmo nos ingredientes que compõem a feijoada, tida como alimento dos escravos. O que se tinha como alimento base era às vezes o feijão combinado a algum outro ingrediente, como mandioca ou milho. Isso nos dá uma pista sobre o feijão enquanto alimento para as camadas mais baixas da sociedade e o estigma que carrega.

O segundo autor que merece destaque no que refere a hábitos alimentares nas Ciências Sociais é o folclorista Luís da Câmara Cascudo.

\footnotetext{
95 DÓRIA, Carlos Alberto. Formação culinária brasileira.. Op. Cit. p. 47.

96 DAVATZ, Thomas. Memórias de um Colono no Brasil (1850). São Paulo, EDUSP/ Biblioteca Histórica Brasileira/ Martins Editora, 1972. p. 71.

97 D'ORBIGNY, Alcides. Viagem Pitoresca Através do Brasil. São Paulo, Belo Horizonte, EDUSP/ Itatiaia Editora, 1976. p. 137.
} 
Também dentro desta produção que buscava as raízes do Brasil na tripla influência, teve sua principal obra sobre alimentação, História da Alimentação no Brasip8, produzida anos depois, em 1967. É sabido que, se por um lado, ele demorou ao redor de vinte anos para escrever este livro, por outro, já havia produzido outros textos, como a Antologia do Folclore Brasileiro ${ }^{99}$, com a primeira edição em 1944, o que coloca este autor e obra dentro do contexto Modernista, como mostramos nas conversas que tinha com Mário de Andrade.

Aquela obra, História da Alimentação no Brasil, pode ser considerada o grande trabalho que se dedica a entender a formação da alimentação brasileira fundada nestas três contribuições - o índio, com seu cardápio, o africano, com sua dieta, e o português, com a ementa. Apesar de outra já ter sido publicada, Cozinheiro Nacional, anônima, ela era "quase uma obra de ficção"100, tentando adaptar os ingredientes à forma francesa de cozinhar. Não por acaso Cascudo nomeia estas raízes - portuguesa, africana e indígena de forma distinta.

Se nos atentarmos um pouco mais em como Cascudo designa suas divisões - portuguesa, africana e indígena - já podemos começar a notar as sutis diferenças de peso que ele determinará para cada uma delas. A palavra "ementa", que dá o nome no caso dos portugueses, também pode ser entendida, além de cardápio, como ideia, pensamento ou registro escrito ${ }^{101}$. Essa ênfase nos mostra os lusitanos enquanto detentores do registro e da organização desta culinária, a égide portuguesa na formação da cultura alimentar. Da mesma forma, por "cardápio" (que corresponde à influência indígena) compreendemos também refeição, pratos disponíveis ${ }^{102}$, que pressupõe uma contribuição enquanto ingrediente e preparo. Por último, "dieta", que seria dos africanos, significa, entre outras definições, "cota habitual de alimentos sólidos e líquidos que uma pessoa ingere"103. Aos africanos

\footnotetext{
98 CASCUDO, Luis Câmara. História da alimentação no Brasil.. Op. Cit.

99 CASCUDO, Luis Câmara. Antologia do Folclore Brasileiro. São Paulo: Global, 2001.

100 DÓRIA, Carlos Alberto. Formação da Culinária Brasileira...Op. Cit. p. 27.

101 HOUAISS, Antonio e VILLAR, Mauro de Salles. Op. Cit. p. 1121.

102 Idem, Ibidem, p. 623.

103 Idem, Ibidem. p. 1037.
} 
ficariam os ingredientes, que hoje sabemos que foram trazidos principalmente pelos portugueses nas rotas do tráfico. ${ }^{104}$

A separação por essas diferentes atribuições nos dá uma pista de como Cascudo irá abordar durante a obra os três pilares da alimentação brasileira, atribuindo aos portugueses o comando central desta formação, aos indígenas o fornecimento daquilo que sabiam sobre a terra que habitavam, com produtos nativos e algumas técnicas, e ao africano com basicamente o fornecimento de ingredientes. Ele parte de uma vasta pesquisa bibliográfica e etnográfica para propor um recorte étnico entendendo que as bases das receitas portuguesas foram preenchidas por ingredientes e técnicas africanas e ameríndias. Como era de se esperar para a época, Cascudo não estava preocupado com as diferenças e conflitos, assim como Gilberto Freyre, e sim em explicar a formação da unidade. Sua contribuição, além da vasta pesquisa que fez, foi indicar a supremacia portuguesa. Porém, o autor coloca toda a diversidade africana e indígena dentro de grupos fechados, achatando sua complexidade e o negro fornecendo aquilo que sua condição de escravo não permitia. Entendemos que até o final da escravidão quem fornecia produtos vindos da África eram os portugueses por meio das trocas coloniais. O que se formou de cozinha africana, por exemplo, na Bahia, está muito mais vinculado à liberdade do que ao período escravocrata ${ }^{105}$.

Dentro do movimento da primeira metade do século $X X$ identificamos outros escritos nos quais o feijão aparece como elemento de representação. A proposta desta primeira pesquisa não é buscar à exaustão todas as citações, e sim encontrar autores-chave para entender a época como nosso objeto de estudo aparece e qual o seu papel na formação do mito nacional.

Oswald de Andrade, um dos escritores que promoveram a Semana de 1922, em Pau Brasil, no poema "A roça", coloca106 (grifo nosso):

Os cem negros da fazenda

Comiam feijão e angu

104 Paula Pinto e Silva. Aula Introdutória do curso, Câmara Cascudo ao alcance de todos. Ministrada no C5, no dia 19/01/2013.

105 DÓRIA, Carlos Alberto. Formação da culinária .... Op. Cit. p. 44.

106 ANDRADE, Oswald de. Pau Brasil. Paris: Sans Pareil, 1925 p. 40. 


\title{
Abóbora chicória e cambuquira \\ Pegavam uma roda de carro \\ Nos braços
}

Mário de Andrade, em Paulicéia Desvairada de 1922, também escreve um poema que trata da separação entre elite e consumo de feijão, o alimento que detém as tradições - "Ode ao burguês"107 (grifo nosso):

\author{
Eu insulto o burguês-funesto! \\ O indigesto feijão com toucinho, dono das tradições! \\ Fora os que algarismam os amanhãs! \\ Olha a vida dos nossos setembros! \\ Fará Sol? Choverá? Arlequinal! \\ Mas à chuva nos rosais \\ O êxtase fará sempre Sol!
}

Nota-se nestes dois trechos que a referência de oposição entre os hábitos da elite difere daquilo que eles atribuem como tradicional -o feijão, que é o dono das tradições, seria indigesto para o burguês. Em Macunaíma, obra expoente do Modernismo, Mário de Andrade não deixa de retratar o nosso antiherói se alimentando de feijão ${ }^{108}$ (grifo nosso):

Oibê estava cozinhando a comidinha dele. Macunaíma não tinha fome nenhuma porém botou a gaiola no chão e só de embusteiro esfregando a mão na barriga fez:

- Juque! Oibê resmungou:

- Que é isso gente!

- É fome, é fome.

Oibê pegou numa gamela, botou cará com feijão dentro, encheu uma cuia com farinha-d'água e ofereceu pro herói.

Como percebemos em diferentes situações, o feijão aparece associado ao alimentar-se popular. Mesmo com outros alimentos à mesa, ele permanece no imaginário da suposta unificação da cultura e hábito nacional, muitas vezes

\footnotetext{
107 ANDRADE, Mário de. Paulicéia Desvairada, São Paulo: EDUSP, 2003 p. 31. 108 ANDRADE, Mário de. Macunaíma: o herói sem nenhum caráter. São Paulo: Agir Editora, 2008 p. 178.
} 
associado a uma fonte de carboidrato (que difere, dependendo do lugar) -o feijão estaria sempre presente.

Detendo-nos um momento na obra de Monteiro Lobato, conseguimos identificar importantes elementos. O escritor, editor e empresário era um ávido defensor do que dizia ser cultura nacional. Como já posicionamos antes, ele estava preocupado com o progresso da nação e, ao mesmo tempo, em resgatar elementos tradicionais com uma estética tupinipiquim ${ }^{109}$. “(...) Sua produção constitui um verdadeiro retrato de época. Nesse painel socioeconômico, político e cultural do período, sobressai a defesa intransigente da nacionalidade contra o hábito da cópia e do plágio"110. A cozinha é um elemento importante no retrato que constrói e em seus debates. Monteiro Lobato, que era um defensor dos hábitos caipiras e esbravejava contra a tendência das elites de tentar imitar hábitos europeus, escreveu ${ }^{111}$ :

- Oh não! Comer o que se quer é regionalismo sórdido. Comese o que é de bom tom comer. Manducar leitão assado, picadinho, feijoada, pamonha e milho verde, moqueca e outros petiscos da terra é uma vergonha tão grande como pintar paisagens locais, romancear tragédias do meio, poetar sentimentos do povo. Até o uso dessa língua que herdamos está em via de tornar-se ignomioso. Na altíssima roda já a repudiaram para uma idílica mancebia com o francês argelino. Que dirá o estrangeiro se nos pilhar a comer (que horror, meu Deus!) tutu com torresmo, esta vergonhosa pilança regional, ou coisas semelhantes?

Essa diferenciação está presente em vários autores, mas um aspecto de Lobato merece atenção. Na sua obra infantil, O sítio do Pica-pau Amarelo ${ }^{112}$, o que nos chama atenção é a diferenciação que Monteiro Lobato faz da cozinha

109 Este era uma das grandes rusgas que Lobato tinha com os modernistas que estão registradas em alguns de seus muitos artigos no Estado de São Paulo. O autor dizia que o grupo modernista tinha que adotar uma estética genuinamente brasileira e não importar alguns padrões, como o expressionismo e "abrasileirá-lo" com temas desta terra. In PASSINI, Enio. Op. Cit. p. 34.

110 CAMARGOS, Marcia e SACHETTA, Vladimir. À mesa com Monteiro Lobato. São Paulo: Senac, 2008. p. 09.

111 LOBATO, Monteiro. Ideias de Jeca Tatu. São Paulo: Globo, 2008. p. 135.

112 LOBATO, Monteiro. Histórias de Tia Nastácia e O Pica-pau Amarelo. São Paulo: Círculo do Livro, 1986. 
da Dona Benta e da Tia Nastácia. A primeira, que era a senhora da casa, não cozinhava diariamente, no cotidiano. A ela eram reservadas as ocasiões especiais e a cozinha letrada, de farinha branca. Passado alguns anos, quando a editora de Monteiro Lobato lançou o livro de receitas, o nome dado foi Dona Benta. Isso já diz muito. Este livro foi a primeira grande compilação de receitas para uso urbano e pelo nome logo já identificamos que era o livro para a senhora de classe média e alta cozinhar esporadicamente. Tanto o é que poucas receitas encontramos com feijão - ao todo são dez ${ }^{113}$.

Este alimento estava no ambiente da Tia Nastácia, que era a negra que cozinhava todos os dias, detentora do saber popular, mimético, que é passado pela oralidade. Este saber não carecia de registros, pois era aquilo que se fazia no dia a dia. Pedrinho, no volume "História de Tia Nastácia", nos diz"114.

- Uma ideia que tive. Tia Nastácia é o povo. Tudo que o povo sabe e vai contando de um para o outro, ela deve saber. Estou com plano de espremer Tia Nastácia para tirar o leite do folclore que há nela.

Emília arregalou os olhos.

- Não está má a idéia, não, Pedrinho! Às vezes a gente tem muita coisa interessante em casa e nem percebe.

- As negras velhas - disse Pedrinho - são sempre muito sabidas. Mamãe conta de uma que era um verdadeiro dicionário de histórias folclóricas, uma de nome Esméria, que foi escrava de meu avô. Todas as noites ela sentava-se na varanda e desfiava histórias e mais histórias. Quem sabe se Tia Nastácia não é uma segunda Tia Esméria?

Se o povo passava um para o outro o conhecimento cotidiano, o folclore, os hábitos, passava também as receitas e o modo de preparo. Tia Nastácia era uma excelente cozinheira, acalmava dragões, alegrava crianças. Se ela errasse o feijão, o problema era grave ${ }^{115}$ :

113 OLIVEIRA, Débora Santos de S. - A Transmissão do Conhecimento Culinário no Brasil Urbano do Século XX. Dissertação de Mestrado. FFLCH-USP, São Paulo, 2010.

114 LOBATO, Monteiro. Histórias de Tia Nastácia .... Op. Cit. p. 08.

115 Idem, ibidem. p. 261. 
Dona Benta achou muito esquisito o caso, e mais ainda quando ao jantar o feijão apareceu com 'bispo' - isto é, queimado.

- O feijão está com 'bispo', vovó! - gritou Narizinho fazendo careta.

- Não é possível menina! - Protestou Dona Benta. - Tia Nastácia nunca, nunca jamais, queimou o feijão, nem coisa nenhuma. Sempre foi uma cozinheira perfeita.

- Pois queimou o feijão, sim - prove.

Dona Benta provou e viu que era mesmo.

Apesar de Lobato fazer a crítica à elite, que só come o que é de bom tom comer, que deixa de lado o que é da terra, quando ele vai fazer o registro escrito das receitas e publicá-las, seu foco é a mulher branca de classe média e alta que fará a comida nesses moldes das elites. Só que a imitação francesa nada trazia para a resposta que estavam buscando, ela era muito mais próxima e similar às outras elites do que às peculiaridades que eram importantes retratar na época enquanto projeto de nação. No Brasil dos meados da primeira metade do século $X X$, queriam entender e forjar o que se chamou de identidade nacional. Aqui, literatura, artes plásticas, culinária e outras manifestações estavam juntas para formar este imaginário. "Neste contexto, Monteiro Lobato era a voz do interior, que buscava o gostinho das raízes nacionais." $" 116$

Essa separação entre hábitos das elites e hábitos populares estão presentes em muitas das produções modernistas, como as que colocamos neste primeiro capítulo. Segundo Sidney Mintz, no que tange à alimentação, quando há o desejo de se criar uma imagem única do lugar, na perspectiva de diferenciação, a busca pelos elementos que sustentarão esse fenômeno só pode partir dos hábitos das classes baixas. Afinal, as elites podem e compartilham hábitos entre si, elas são mais homogêneas ${ }^{117}$ e se espelham; elas buscam hábitos que a diferenciem das classes menos favorecidas e que as igualem entre si.

\footnotetext{
116 CAMARGOS, Marcia e SACHETTA, Vladimir. Op. Cit. p. 11.

117 MINTZ, Sidney. Tasting food, tasting freedom: excursions into eating, culture, and the past. Boston, 1996. p. 96.
} 
Neste sentido, os estudos de Fernand Braudel sobre o luxo são esclarecedores. O luxo - esse ardente desejo pela conquista do supérfluo -, para o autor, é a expressão cabal de outro desejo: o de distinção social. Pouco importa a moda da época, que é de fato efêmera; o luxo continua e continuará existindo e representando "uma sempre eterna 'luta de classes"”118. Ele deixa isso bem claro ao citar uma frase de Gaston Bachelard: "A conquista do supérfluo dá uma excitação espiritual maior do que a conquista do necessário. O homem é uma criatura do desejo e não uma criatura da necessidade."119 Essa ideia é condizente com o eixo da obra de Norbert Elias, O Processo Civilizador. No primeiro volume, o autor traça o desenvolvimento dos costumes por meio da comparação entre dois conceitos distintos: a kultur alemã e a civilisation francesa. Uma notável oposição entre esses dois conceitos está na relação estabelecida nas duas sociedades entre uma burguesia emergente e uma nobreza consagrada. A burguesia francesa busca alcançar status junto à nobreza, copiando seus hábitos, vestimenta e valores. Isso, de certa forma, faz com que a nobreza busque ainda mais diferenciar-se dessa burguesia -é uma sociedade em que as duas classes convivem, mas ainda assim são essencialmente distintas. Na sociedade alemã há uma cisão entre nobreza e burguesia; esta preza pela virtude pessoal e considera a nobreza frívola e oca $^{120}$.

O Brasil não se diferia disso. Com as elites olhando para a França, os que buscavam falar de legitimidade da nação geralmente usavam hábitos e costumes populares. A autenticidade precisava estar respaldada naquilo com o que convivíamos.

\footnotetext{
118 BRAUDEL, Fernand. Civilização material e Capitalismo. Séculos XV-XVIII. Lisboa: Cosmos, 1970. Tomo I. p.147.

119 Braudel argumenta com a universalidade, falando dessas características que são próprias da espécie humana, mas ignora que conceitos e categorias são produtos sociais. As estruturas de Braudel dever-se-iam remeter apenas à sociedade européia, ocidental, com a consciência de que interpretar a própria sociedade com os próprios elementos conceituais é diferente de pensar que essas categorias podem ser usadas indiscriminadamente, sem ressalvas, para a interpretação de outras sociedades, muito distantes da ocidental. Afinal, as categorias de análise também são produtos históricos. Essa busca pela distinção pessoal através da posse e consumo de gêneros de que prescinde a sobrevivência, que se convencionou chamar luxo, é um elemento vindo do mundo europeu e que remete a práticas desse contexto. Nada pode garantir a um europeu, quando ele vê em outras sociedades e contextos históricos elementos familiares, que eles signifiquem para a outra cultura o mesmo que para si. Idem Ibidem. p.147. 120 ELIAS, Norbert. O Processo Civilizador. Rio de Janeiro: Jorge Zahar Editor, 1994. Volume I: Uma História dos Costumes.
} 
Como estamos falando de feijão, precisamos fazer um parêntese sobre a feijoada. No filme Macunaíma, de 1969, dirigido por Joaquim Pedro de Andrade, a macarronada de Venceslau Pietro Pietra, presente no livro, foi substituída por uma feijoada. Não por acaso. "A feijoada é, para nós, uma espécie de hino nacional comestível. Comungamos uma ideia sólida e simples de nação: um imenso território, uma unidade linguística, uma bandeira, um hino, uma seleção de futebol e um prato -a feijoada."121

Este prato ritual é emblemático: nascido como comida de escravo, símbolo da miscigenação nacional, seria a representação das três raças. Os atuais estudos nos mostram outra perspectiva. Para Henrique Carneiro, a técnica de cozimento lento e com caldo foi trazida pelos portugueses, que por sua vez foi apropriada dos judeus que foram à Península Ibérica ${ }^{122}$. O feijão, principalmente da espécie Phaseolus vulgaris, foi utilizado para fazer o cozido que já era consumido nas terras europeias. Um alimento que não era central na dieta nativa, foi ganhando importância por trazer um pouco do que se tinha no além-mar. Mas a feijoada, como conhecemos hoje, tem seus primeiros registros bem mais recentes. "Mesmo o folclorista Câmara Cascudo, que não encontrou a feijoada como 'prato completo' antes do século XIX, reconhece que ele se difundiu a partir daquele século como prato urbano, especialmente em hotéis e pensões cariocas"123. Carne era coisa rara nos tempos coloniais e não eram destinadas aos escravos, nem suas partes ditas hoje como menores, como as que são usadas na feijoada ${ }^{124}$. Estas foram incorporadas à dieta dos negros apenas quando os mesmos começaram a poder comprar pequenas partes das peças mais baratas com o que vendiam de suas hortas.

A feijoada serviu como signo de brasilidade, e o feijão se tornou "a expressão mais clara do patrimônio culinário brasileiro e da sua dinâmica"125.

121 DORIA, Carlos Alberto. Formação culinária brasileira... Op. Cit. p. 66.

122 CARNEIRO, Henrique. "Comida e Sociedade: significados sociais na história da alimentação". Op. Cit. p. 76.

123 DORIA, Carlos Alberto. "Feijões como patria, locus \& domus ... Op. Cit. p. 128.

124 Marshall Sahlins observa que o conceito de parte nobre é construído socialmente. Se para nós, enquanto ocidentais, o que é nobre é o que nos afasta da figura animal, o que não lembra nem enquanto forma - cortes de carne como filé mignon, por exemplo; para os chineses a parte nobre é aquela que lembra o movimento - orelha ou pés. SAHLINS, Marshall. Cultura e Razão Prática. Rio de Janeiro: Jorge Zahar Editora, 2003.

125 Idem, ibidem. p 134. 
Se por um lado por ser um alimento nativo da América que foi paulatinamente se tornando importante na mesa dos brasileiros, por outro porque foi percebido como tal pelos atores que queriam mostrar o que era este país no início do século XX. A apropriação do feijão como alimento nacional foi um elemento importante e amplamente usado pelo projeto Modernista, como já dissemos, no sentido maior, de momento histórico, e não apenas de movimento literário, para a construção da imagem da nação chamada Brasil. 


\section{Capitulo 02 \\ O feijão no Brasil}

\subsection{Afinal, o que é feijão?}

O termo feijão é impreciso. Envolve algumas espécies ou gêneros e pode variar de região para região ${ }^{126}$. É conhecido como kidney bean, French bean, dwarf bean, flageolet, string bean, snap bean, haricot ou frijoles. ${ }^{127}$ Sob a ótica botânica, pertencem à família das leguminosas (Leguminosae ou Fabacea, após a atualização), mas variam. "Nem sempre o que chamamos feijão é mesmo feijão. Veja o exemplo do feijão-de-corda. Recebe esse nome por espalhar-se que nem corda, trepadeira que se refestela por outros cultivos como o milho, por exemplo. É feijão pela vox populi, mas outro gênero, segundo a visão científica." ${ }^{28}$. Este seria o Vigna unguiculata, espécie à qual também pertence o feijão-fradinho, muito consumido no Nordeste como feijão verde ou base para o acarajé, por exemplo ${ }^{129}$.

$\mathrm{Na}$ Europa, o consumo de leguminosas que receberam o nome de feijões vem desde a Alta Antiguidade e atribuem sua origem à região asiática e médio oriental, como mostra o mapa que vem a seguir. Os europeus têm registro de consumo de feijões nas escavações feitas por Schliemann na suposta cidade de Troia e atribui-se que tenha sido consumido na Grécia e Roma ${ }^{130}$. Muitos textos identificam o feijão como americano, mas isso é apenas

\footnotetext{
${ }^{126}$ Segundo o dicionário Houaiss, feijão é um fruto do feijoeiro e é designação comum a várias plantas da familia das leguminosas, sufamilia papilionoída, espécie às do gênero Phaseolus, e algumas do gênero Vigna. HOUAISS, Antonio e VILLAR, Mauro de Salles. Dicionário Houaiss de Língua Portuguesa. Rio de Janeiro: Objetiva, 2001. p. 1320.

127 FELIPPE, Gil. Op. Cit. p. 252.

128 BARBARA, Danusia. Feijão - aromas e sabores da boa lembrança. São Paulo: Senac, 2005 p. 11.

129 "Por outro lado, uma única variedade de feijão pode receber nomes distintos, complicando a abordagem nominativa. Na Índia o feijão-fradinho (chamado chowlee ou gubgub) é conhecido há mais de 3.000 anos; no Brasil, o mesmo feijão fradinho (Vigna unguiculata) pode ser encontrado como feijão-bongalon, feijão-caupi, feijão miúdo, feijão de corda (sub variedade) e assim por diante. Ele chegou ao Nordeste vindo da África, trazido pelos portugueses. É consumido na forma de vagens verdes, sementes verdes ou maduras, sendo que estas últimas podem ser secas ou frescas17. É com o feijão-fradinho que se prepara o acarajé, prato típico da culinária negra,negros islamizados da Bahia." DÓRIA, Carlos Alberto. "Feijões como pátria, locus \& domus ... Op. Cit. p. 07.

130 BLOCH-DANO, Évelyne. Op. Cit. p. 142.
} 
uma parte da história. Senão como ele já seria consumido na Antiguidade europeia?

A confusão vem do fato de o termo designar plantas diferentes, mesmo sendo da mesma família, principalmente a Vigna e o Phaseolus. Este embrólio ficou também por uma confusão léxica europeia, como explica Bloch-Dano ${ }^{131}$ :

O grego phaseolos deu origem ao latim faselus, que se
transformou em fasol, fasiol, fayol, depois... fayot. Até o século
XVII, emprega-se o termo fasiol. Nas mais das vezes, em
francês usa-se indiferentemente a palavra 'pois' (ervilha) ou
'fève' (fava). Já sabemos que, da mesma maneira, durante
muito tempo o termo légume (leum) designa o conjunto de
leguminosas, ervilhas, favas, lentilhas, ervilhacas, feijões, etc.
Quanto ao inglês bean, ao alemão bohne, ao holandês boon,
ao sueco bona, todos derivam de uma raiz germânica bauna,
que significa fava.

A necessidade de classificar espécies e a diferenciação exata de cada uma é recente comparada com o uso dessa leguminosa. Nosso aparato linguístico vulgar ainda não acompanha plenamente esse imperativo, com exceção das diferenciações científicas. Valendo-se dela, podemos ter uma noção mais específica do que estamos falando.

Aqui tratamos principalmente do gênero Phaseolus, que corresponde às 55 espécies mais cultivadas (ao todo são mais de 500), especificamente da espécie Phaseolus vulgaris que representa o feijão-comum. "O feijão-comum é uma planta anual herbácea, trepadora ou não, pertencente à família Leguminosae, subfamília Papipilionoideae, gênero Phaseolus. Está classificado como Phaseolus vulgaris L."132 Outras espécies aparecem cultivadas, como o feijão-da-espanha (Phaseolus coccinus), feijão-de-lima (Phaseolus lunatus) e Tepary bean (Phaseolus acutifolius).

131
132
BLOCH-DANO, Évelyne. Op. Cit. p. 142-143. http://www.cifeijao.com.br/index.php?p=aspectos botanicos acessado em 30/07/2013. 
Resumindo, para o feijão comum temos:

Reino: Vegetal

Ramo: Embryophytae syphonogamae

Sub-ramo: Angiospermae

Classe: Dicotyledoneae

Subclasse: Archichlamydeae

Ordem: Rosales

Família: Fabaceae

Subfamília: Papilionoideae

Tribo: Phaseolineae

Gênero: Phaseolus L.

Espécie: Phaseolus vulgaris L. ${ }^{133}$

Porém, temos de reconhecer que nem todas as pesquisas separaram, por exemplo, o feijão-fradinho das espécies tidas como feijão-comum, do gênero Phaseolus vulgaris. Assim, sempre que possível, separaremos as espécies ou tentaremos encontrar como cada agência engloba no termo feijão as diferentes plantas.

Estudos variam sobre os registros mais antigos de cultivo e origem deste gênero, Phaseolus, dentro do território americano. Alguns encontram apontamentos do feijão, na América, mais especificamente na América do Sul, região do atual Peru, desde nove mil anos antes de Cristo ${ }^{134}$. Já Gil Felippe coloca que na região do atual México tem-se registro desde 5.000. a.C. e no atual Peru desde 6.000 a.C. ${ }^{135}$ Sabemos que esta planta foi domesticada independentemente tanto nos Andes peruanos quanto no México e, segundo Leonardo Cunha Melo, pesquisador da EMBRAPA ${ }^{136}$, essas duas origens são visíveis, traduzidas no tamanho do grão. Os de origem andina são maiores que os de origem mesoamericana.

\footnotetext{
133 SANTOS, João Bosco dos \& GAVILANES, Manuel Losada. "Botânica". In: VIEIRA, Clibas, JUNIOR, Trazilbo \& BORÉM, Aluízio (Ed.). Feijão. Viçosa: EFV, 2006. p. 41.

134 BARBARA, Danúsia. Op. Cit. p. 13.

135 FELIPPE, Gil. Op. Cit. P 252. Algumas fontes apontam para a Mesoamérica em 7000 a.C. BUENROSTRO, Marco. "El frijol". In: CASTILLO, Gilda (org.). El frijol - un regalo de México al mundo. Ciudad de México: Fundación Herdez, 2011. p. 49-57.

136 Entrevista concedida a pesquisadora em 10.09.2014.
} 
Atribui-se para cada região o surgimento das diversas espécies do gênero Phaseolus. Porém os autores divergem se esse gênero é ou não apenas americano. Há os que identificam em outros locais, como Phaseolus acontifolius, originário da Índia, Birmânia e Paquistão; Phaseolus angularis do Japão e cultivado há tempos na China, Coreia, Japão e no Sarawak ou o Phaseolus aureus, cultivado na Índia, mesmo não tendo certeza de sua origem, sabe-se que está nesse território bem antes nas Grandes Navegações. ${ }^{137}$

$\mathrm{Na}$ região mesoamericana foram encontradas evidências dos tipos menores, como o feijão-rosinha. Já no Sul dos Andes estariam os grãos maiores, como o jalo, e no norte dos Andes, as espécies intermediárias ${ }^{138}$. Há ainda uma terceira área de domesticação intermediária, na atual Colômbia ${ }^{139}$. Assim, o feijão-carioca, menor, foi uma mutação que aconteceu no território brasileiro mas possivelmente vinda de variedades com origem mesoamericana, enquanto o rajado, maior, é o mesmo processo, mas com raízes andinas. Do México até a Argentina, o gênero foi encontrado como espécie silvestre como mostra o mapa:

\section{Distribuição do gênero Phaseolus no continente americano}

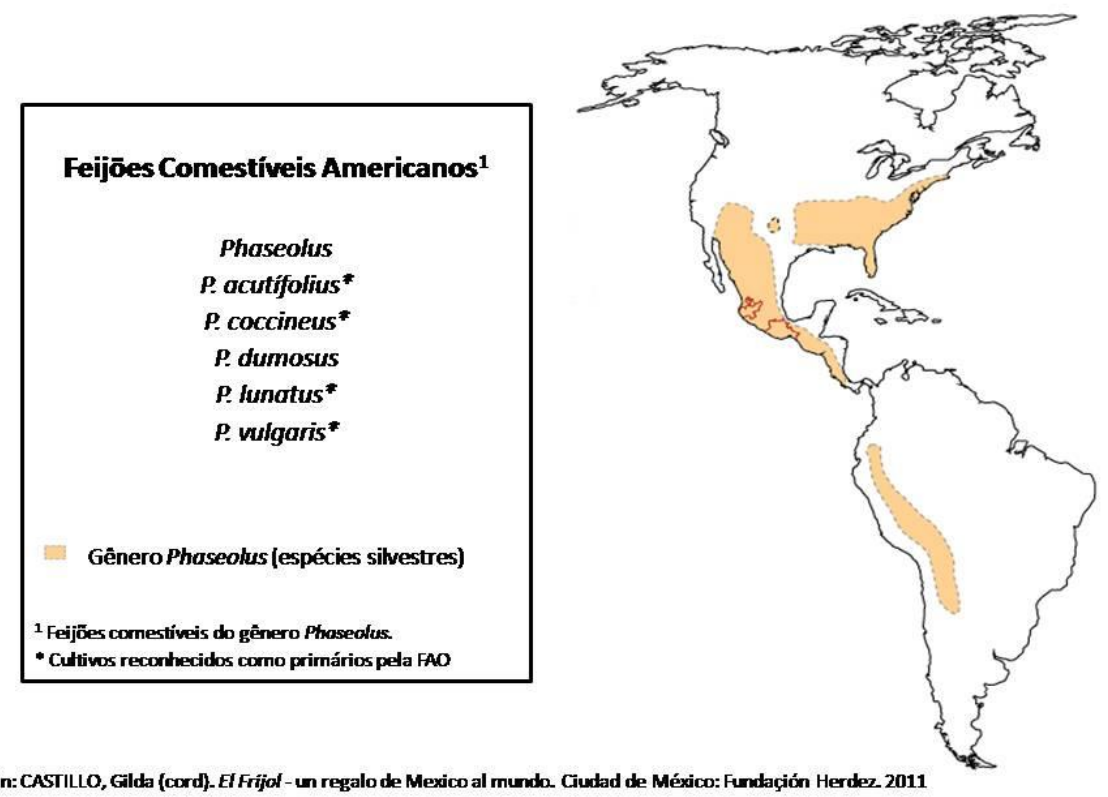

137 FERRÂO, José E. Mendes. A aventura das plantas e os descobrimentos portugueses. Lisboa: Chaves Ferreira, 2005. p. 120.

138 Centro de Inteligência do Feijão. Op. Cit. Acessado em 04/08/2013.

139 SANTOS, João Bosco dos \& GAVILANES, Manuel Losada. "Botânica". In: VIEIRA, Clibas, JUNIOR, Trazilbo \& BORÉM, Aluízio (Ed.). Feijão. Viçosa: EFV, 2006. p. 42. 
Figura 02: Distribuição do gênero Phaseolus no continente americano como espécies nativas

Por seus benefícios para o solo, o feijão compartilhou seu cultivo com outras plantas ${ }^{140}$, principalmente o milho, que é um alimento chave para entender a alimentação pré-colombiana. Como em outras leguminosas, comestíveis ou não, o feijão tem em sua raiz uma bactéria (Rhizobium app). Ela recebe carboidratos da planta e fornece nitrogênio, que enriquece o solo ${ }^{141}$. Segundo Ken Albala, sem o feijão, a terra não aguentaria tamanha população na Mesoamérica, tornando-se fundamental para populações como Maias e Astecas $^{142}$. Quando os europeus chegaram à América, este autor, assim como Paula Pinto e Silva, nos diz que o feijão não foi tido como alimento estranho, pois o colonizador já tinha familiaridade com outros similares ${ }^{143}$, como a lentilha, as favas e outros gêneros de feijão. Assim, ao contrário da batata e do tomate, por exemplo, ele passou a fazer parte da dieta europeia e dos europeus na América mais cedo. Desta forma, ele se espalhou para várias partes do mundo, nas suas variadas formas: "the white navy bean, mottled pinto bean, red kidney bean, black bean, (...) and so forth are all the same species"144.

Mas feijão não é exclusivo da América, como já colocamos. Algumas espécies que são muito consumidas no Brasil são nativas de outros lugares, como o feijão-fradinho, africano, que foi trazido pelos portugueses. Veja 0 mapa a seguir:

\footnotetext{
140 BUENROSTRO, Marco. "El frijol". In: CASTILLO, Gilda (org.). Op. Cit. p. 59.

141 SANTOS, João Bosco dos \& GAVILANES, Manuel Losada. Op. Cit. p. 47.

142 ALBALA, Ken. Op. Cit. p. 129.

${ }^{143}$ ALBALA, Ken. Op. Cit. p. 128. e SILVA, Paula Pinto e. Farinha, feijão e carne-seca: um tripé culinário no Brasil colonial. São Paulo: Senac São Paulo, 2005. p. 78.

144 Tradução livre: feijão branco, feijão rajado, feijão vermelho, feijão preto (...) e assim por diante, são todos da mesma espécie. ALBALA, Ken. Op. Cit. p. 127.
} 


\section{Distribuição das espécies cultivadas do gênero Vignas no mundo}

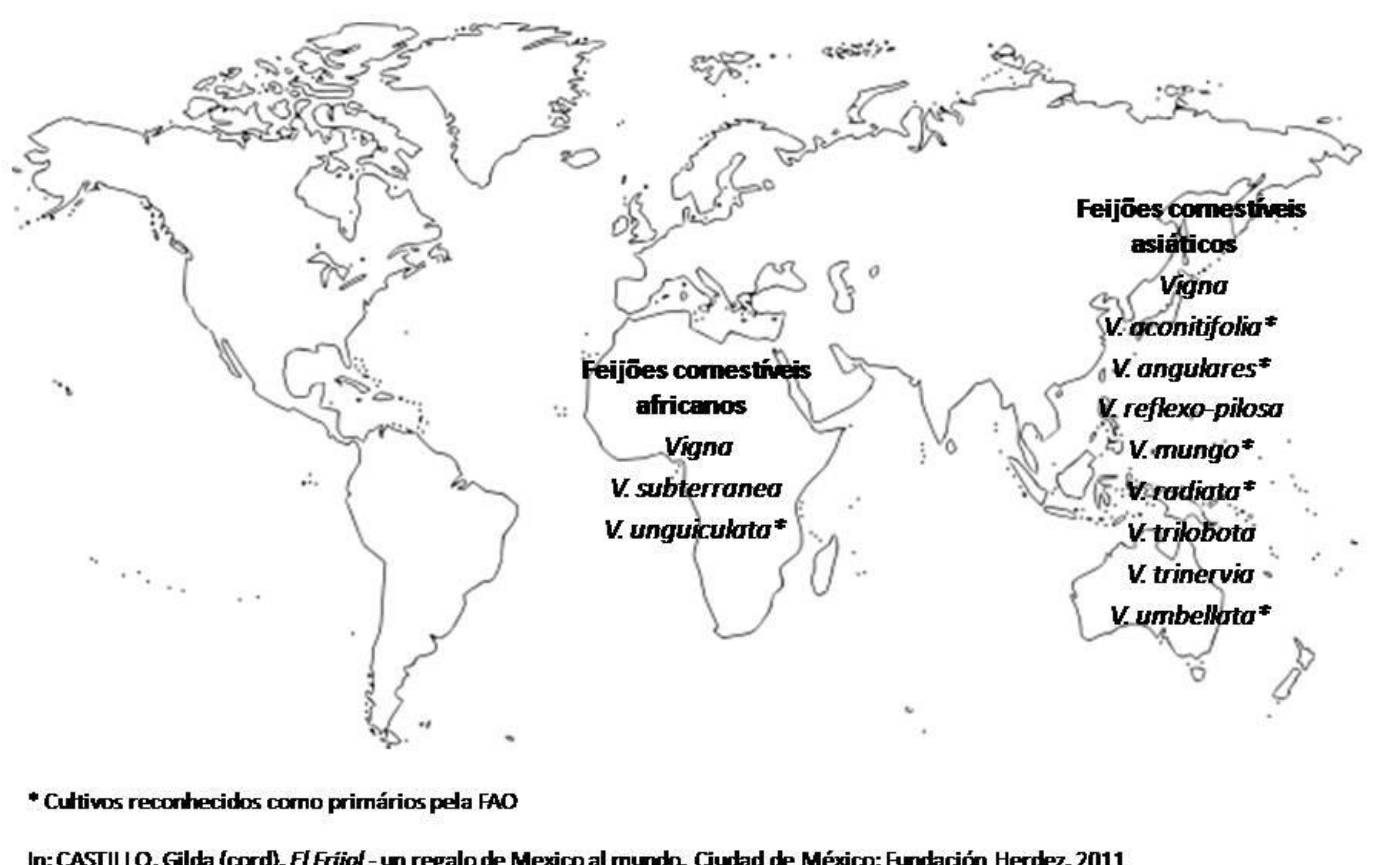

Figura 03: Distribuição do gênero Vignas enquanto nativas

Espécies como a Vigna vieram com as grandes navegações e na colonização do território pelos europeus se tornaram essenciais para alimentação. O caupi, como também é chamado, tem mais resistência à alta temperatura, tanto com muita como com pouca umidade ${ }^{145}$. Um dos motivos de seu cultivo predominar na região Norte e Nordeste, não tão favorável ao feijão comum.

Atualmente, "o feijoeiro comum (Phaseolus vulgaris L.) é a espécie mais cultivada entre as demais do gênero Phaseolus. Considerando todos os gêneros e espécies englobados como feijão nas estatísticas da FAO (Food and Agriculture Organization), este envolve cerca de 107 países produtores em

145 BORÉM, Aluízio \& CARNEIRO, José Eustáquio S. "A cultura". In: In: VIEIRA, Clibas, JUNIOR, Trazilbo \& BORÉM, Aluízio (Ed.). Feijão. Viçosa: EFV, 2006. p. 13. 
todo o mundo". ${ }^{146}$ Como podemos perceber, o feijão tem muitas variedades. Somado ao fato da facilidade de cultivo e adaptação, ele apresenta grande variabilidade de características, como tamanho, cor, ciclo e hábito de crescimento. Por isso, para facilitar o cruzamento e o cultivo, montou-se uma classificação que leva em conta características morfológicas, de adaptação e moleculares. Assim, o feijão comum foi agrupado em seis raças pelos centros de domesticação e doze grupos gênicos como mostra a tabela abaixo:

Tabela 01: Raças e grupos gênicos do feijão-comum cultivado ${ }^{147}$

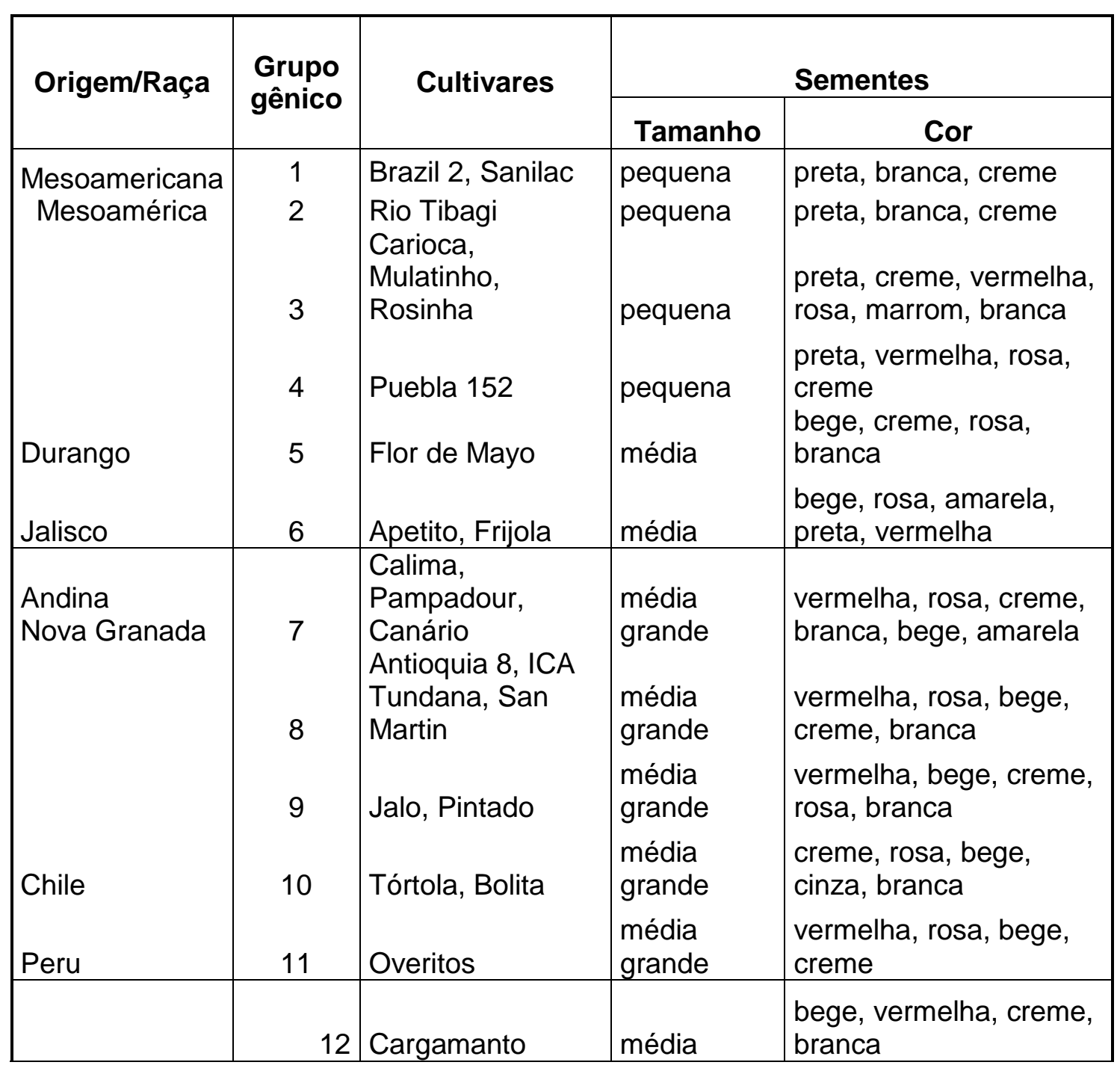

146 Empresa Brasileira de Pesquisa Agropecuária (Embrapa). http://sistemasdeproducao.cnptia.embrapa.br/FontesHTML/Feijao/CultivodoFeijoeiro/importanci a.htm . Acessado em 30/07/2013.

147 SANTOS, João Bosco dos \& GAVILANES, Manuel Losada. Op. Cit. p. 42-43. 
Normalmente, os programas de melhoramento priorizam cruzar cultivares do mesmo grupo gênico, principalmente pela aceitação do local plantado. Com isso, não há a exploração da variabilidade da espécie, mas o comprometimento do melhoramento genético ${ }^{148}$.

Um modo de classificar os feijoeiros é por sua forma de crescimento. Basicamente tem as trepadeiras e as formas arbustivas, mas botanicamente eles são classificados conforme a figura:

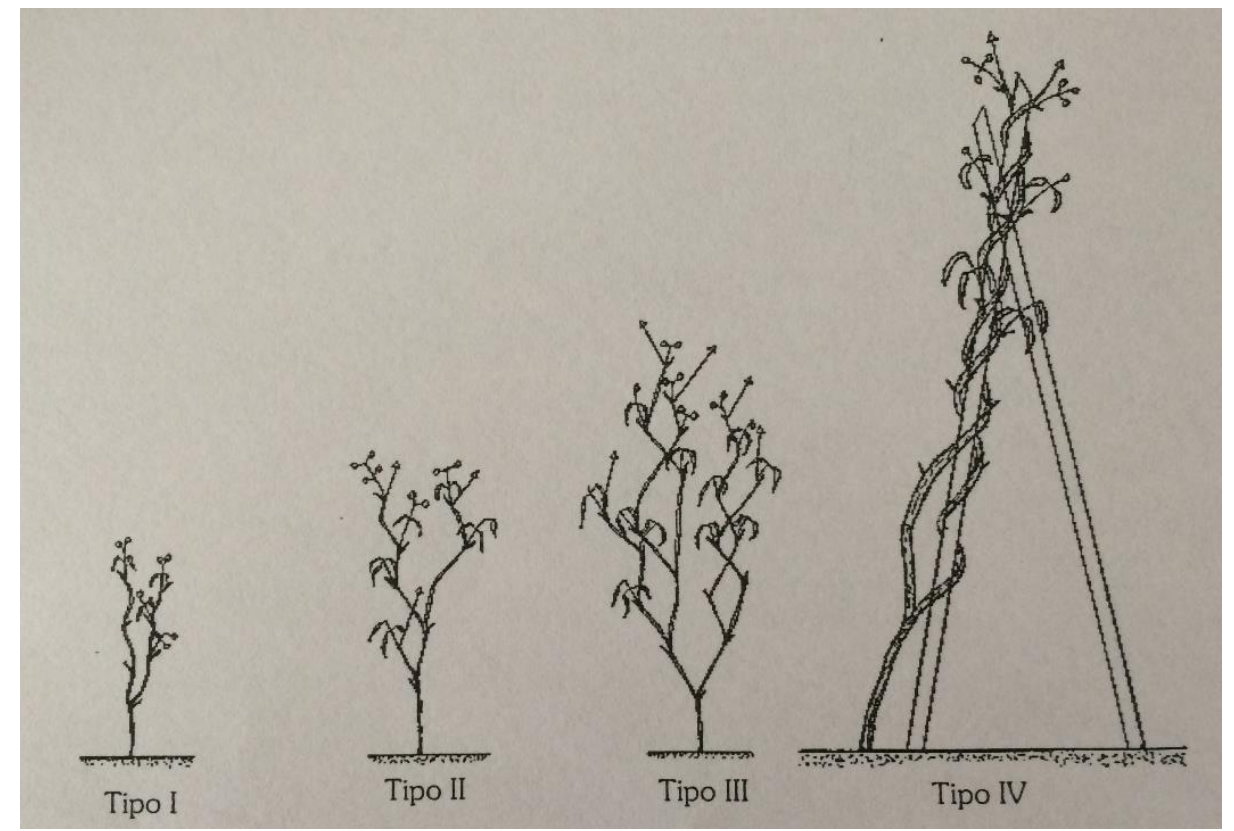

Figura 04: Principais hábitos de crescimento dos cultivares ${ }^{149}$

Segundo o IBGE e CONAB (Companhia Nacional de Abastecimento), não há uma divisão entre os dados estatísticos do feijão-comum e os do caupi (feijão-fradinho ou de corda). Para fins de preços mínimos de garantia, a CONAB classifica em duas tipificações: feijão-anão (Phaseolus vulgaris) e feijão-macassar (Vigna unguiculata) ${ }^{150}$.

\footnotetext{
148 Idem ibidem. p. 44.

149 Idem, ibidem. p. 56.

150 Idem, Ibidem.
} 
Há também o Cajanus Cajan, de menor expressão, possivelmente africano, já foi encontrado no Egito nos túmulos dos reis da $12^{\circ}$ dinastia, sendo cultivado 2.000 a.C. ${ }^{151}$ Foi trazido para o Brasil durante o período colonial e o conhecemos por feijão-guandu, feijão-andu, etc.

Essa confusão léxica nos traz alguma dificuldade para o entendimento do consumo do feijão, principalmente porque torna dispares as ferramentas de análise já que cada órgão tem sua própria denominação do termo. O problema aparece, por exemplo, nas últimas pesquisas do IBGE, que colocam sob o nome feijão-rajado o consumo do feijão-carioca, vindos de raízes diferentes.

\subsection{Produção de feijão no Brasil}

Assim como o próprio nome, as estatísticas sobre a produção de feijão no Brasil e no mundo são vagas. Vale ressaltar que é complexo medir a produção de um alimento como o feijão, já que uma parte dele é usada para o consumo da família produtora e outras vezes doadas para parentes e pessoas próximas, o chamado auto-consumo. Esses dados não estão disponíveis, mas sabe-se que na década 60, portanto anterior ao recorte da pesquisa e em outro contexto socioeconômico, o número apropriado pela família chegava a $40 \%{ }^{152}$ mas hoje estimasse que ele tenha diminuído para $20 \%$. Muitas plantações não entram na conta dos órgãos de estatística, já que são plantadas informalmente no Brasil e no mundo. Alguns países africanos, com maior consumo por habitante de feijão, têm dificuldade de obter dados concretos de produção, tanto pela plantação em áreas remotas quanto pelas guerras e instabilidade política.

A maioria da produção de feijão no Brasil durante o período pesquisado é feita por pequenos agricultores, as vezes consorciada com outros produtos, como o milho. Alguns fatores podem nos ajudar a entender porque grandes

\footnotetext{
${ }^{151}$ FERRÂO, José E. Mendes. Op. Cit. p. 120.

152 FERREIRA, Carlos Magri; DEL PELOSO, Maria José \& FARIA, Luis Claudio. Feijão na economia nacional. Santo Antônio de Goias: Embrapa Arroz Feijão, 2002. p. 15.
} 
produtores não se interessam pela produção do feijão. O risco entra como um dos principais, já que " $90 \%$ da produção brasileira é proveniente do cultivo das 'águas' e da 'seca', ambos de elevado risco"153. O cultivo fica exposto às variações climáticas em períodos importantes, como colheita, floração e formação das vagens. Mais de 45 tipos de doença podem ocorrer no feijão e ele é muito suscetível às pragas. Junta-se a isso a elasticidade de demanda negativa do feijão, conceito da economia explicado anteriormente. Por isso, durante 0 período da pesquisa, em geral, os pequenos produtores representaram $70 \%$ da produção de feijão ${ }^{154}$, apresentando uma queda gradual com o passar do tempo.

Essa é uma cultura estigmatizada como pouco competitiva e nada atraente para os grandes negócios, além de ter recebido, ao longo do processo histórico, o rótulo de pouco produtiva, já que os pequenos produtores quase não utilizam tecnologia e muitas vezes retiram parte da colheita para subsistência. Para termos uma comparação, em 2002, mesmo com o baixo incentivo governamental, o feijão-comum e o caupi ocuparam a quarta maior área colhida (4.140.528 ha), ficando atrás somente de soja (16.365.441 ha), milho (11.750.889 ha), e cana-de-açúcar (5.100.485 ha), mas na frente de alimentos importantes como arroz e café ${ }^{155}$. Porém, a média de produtividade é de $700 \mathrm{~kg} / \mathrm{ha}$, o que é considerada baixa. Esse número não é homogêneo no Brasil, como podemos ver na tabela a seguir:

\footnotetext{
153 BORÉM, Aluízio \& CARNEIRO, José Eustáquio S. Op. Cit. p. 16.

154 IBGE, Censo Agropecuário, 2006. Rio de Janeiro, 2007.

155 IBGE, Sistema IBGE de Recuperação Automática (SIDRA). Disponível em:

http://www.sidra.ibge.gov.br/ Acessado em 10.08.2014.
} 
Tabela 02: Área, produção e rendimento de feijão, safra 2002/2003, nos principais estados produtores do Brasil ${ }^{156}$

\begin{tabular}{|c|c|c|c|}
\hline Estado & Área (ha) & Produção $(\mathrm{t})$ & Rendimento (kg/ha) \\
\hline Paraná & 552.400 & 598.800 & 1.084 \\
\hline Minas Gerais & 432.400 & 483.900 & 1.119 \\
\hline Bahia & 791.800 & 402.100 & 508 \\
\hline Ceará* $^{*}$ & 618.600 & 284.700 & 460 \\
\hline São Paulo & 205.700 & 255.100 & 1.239 \\
\hline Goiás & 130.100 & 246.600 & 1.895 \\
\hline Santa Catarina & 147.500 & 174.400 & 1.182 \\
\hline Rio Grande do Sul & 154.900 & 130.100 & 840 \\
\hline Brasil & 4.291 .300 & 3.178 .200 & 741 \\
\hline
\end{tabular}

A distribuição da produção de feijão no Brasil pode ser medida, entre outros estudos, pelo Censo Agropecuário feito pelo IBGE nos anos de 1975, 1980, 1985, 1995 e 2006, cobrindo o período que perpassa essa pesquisa. Os dados completos aparecem na tabela a seguir ${ }^{157}$ :

156 Companhia Nacional de Abastecimento (CONAB). Disponível em: http://www.conab.gov.br/ Acessado 15.08.2014.

157 IBGE, Sistema IBGE de Recuperação Automática (SIDRA). Op. Cit. 


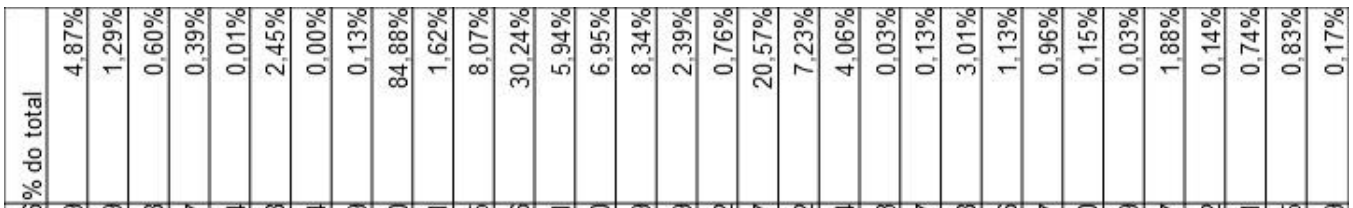

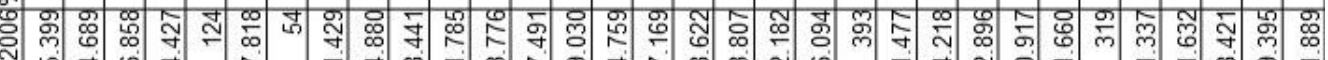
至

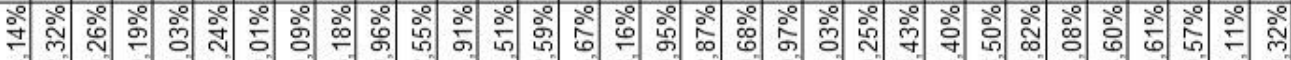

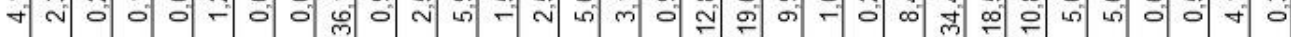
폴

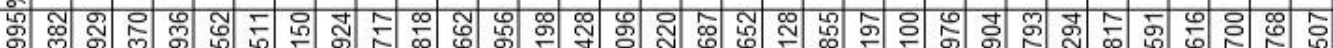
œ ป

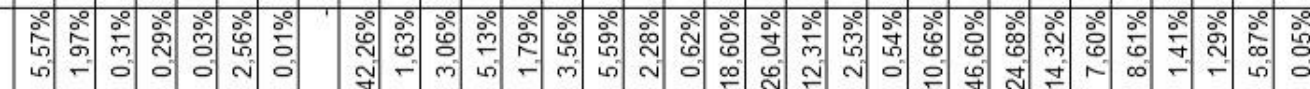
옹

留命

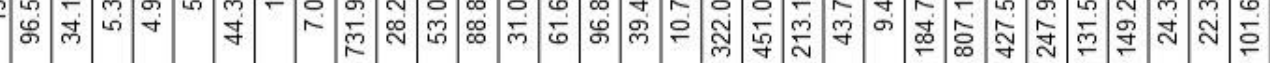

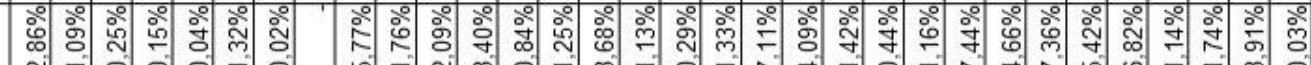
필

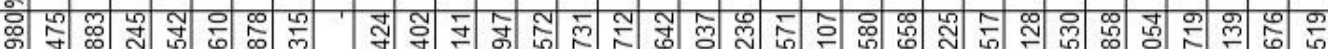
จे ๆ

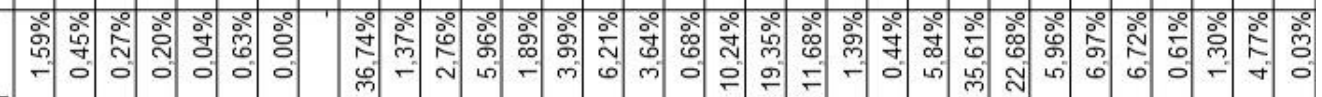
푷 음

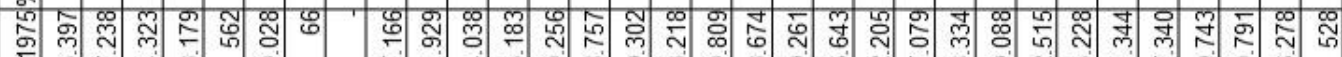

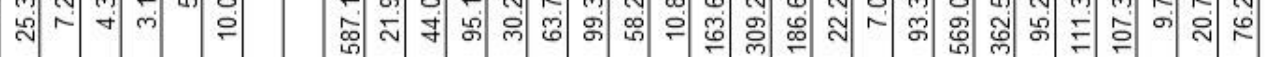


Segundo esses dados, podemos notar que a região Sul era a principal zona produtora de feijão durante a maior parte da pesquisa, como mostra 0 gráfico:

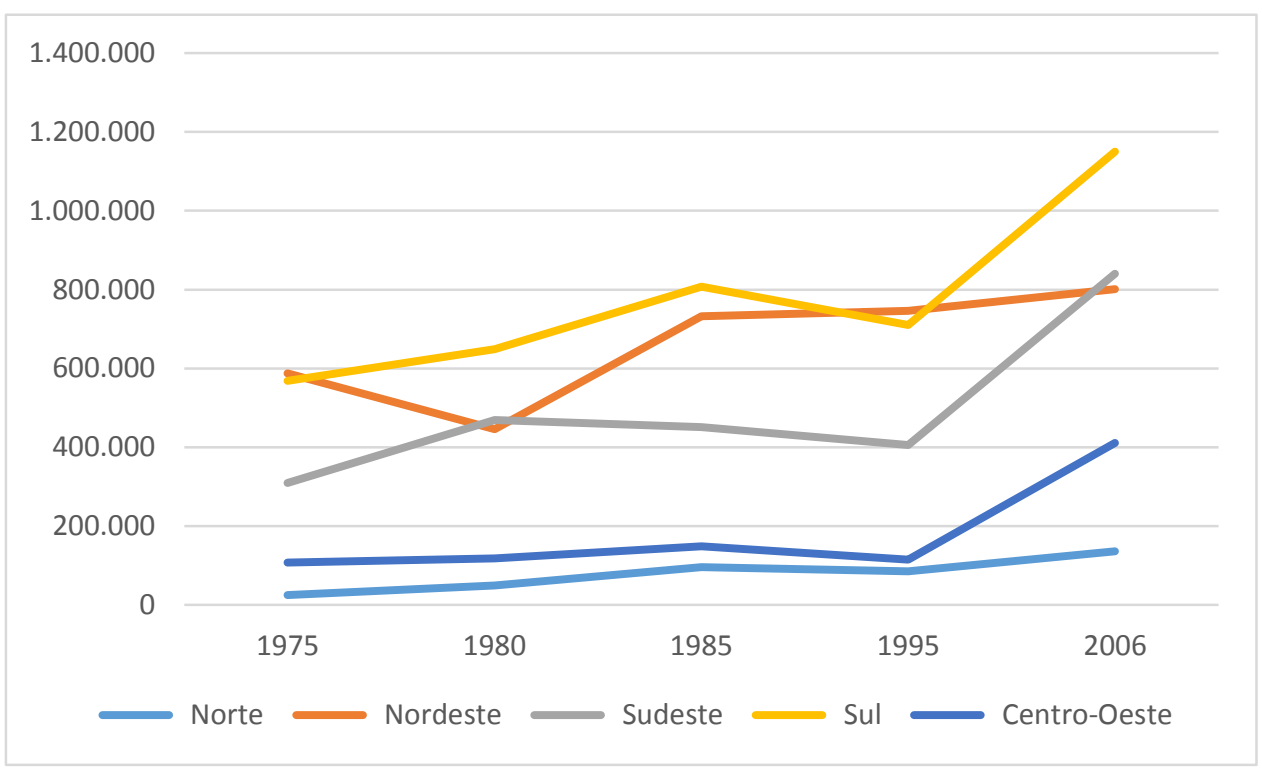

Gráfico 01: Produção de feijão por região ${ }^{158}$

Se adotarmos a visão por período, constatamos que em 1975 o Paraná é o grande produtor de feijão no Brasil, seguido por Minas Gerais e Bahia. De forma geral, o Nordeste tem uma produção distribuída nos estados, se tornando a principal região no plantio de feijão. Essa zona produz, em sua maioria, feijão-caupi. Como dissemos, é uma espécie que aguenta melhor as altas temperaturas comuns no Nordeste, enquanto o feijão-comum,

158 Idem, ibidem. A partir da análise dos dados, entendemos que há uma discrepância entre os números apresentados no Sistema Sidra e a publicação do IBGE referente ao Censo Agropecuário de 2006. Pela disparidade dos valores, optamos por comparar com outras fontes, como CONAB. Essa diferença será elucidada mais adiante. Aqui, optamos por representar neste gráfico os dados de 2006 referente aos valores apresentados pela CONAB. O sistema pode ser acessado por link http://www.sidra.ibge.gov.br/bda/tabela/listabl.asp?c=283\&z=t\&o=11 (último acesso 03/03/15) e a publicação do IBGE http://www.ibge.gov.br/home/estatistica/economia/agropecuaria/censoagro/brasil_2006/Brasil_c ensoagro2006.pdf (último acesso 03/03/15). 
principalmente o preto, é produzido no Sul, especialmente no Paraná. O gráfico a seguir demonstra os dados coletados pelo primeiro Censo Agropecuário ${ }^{159}$ :

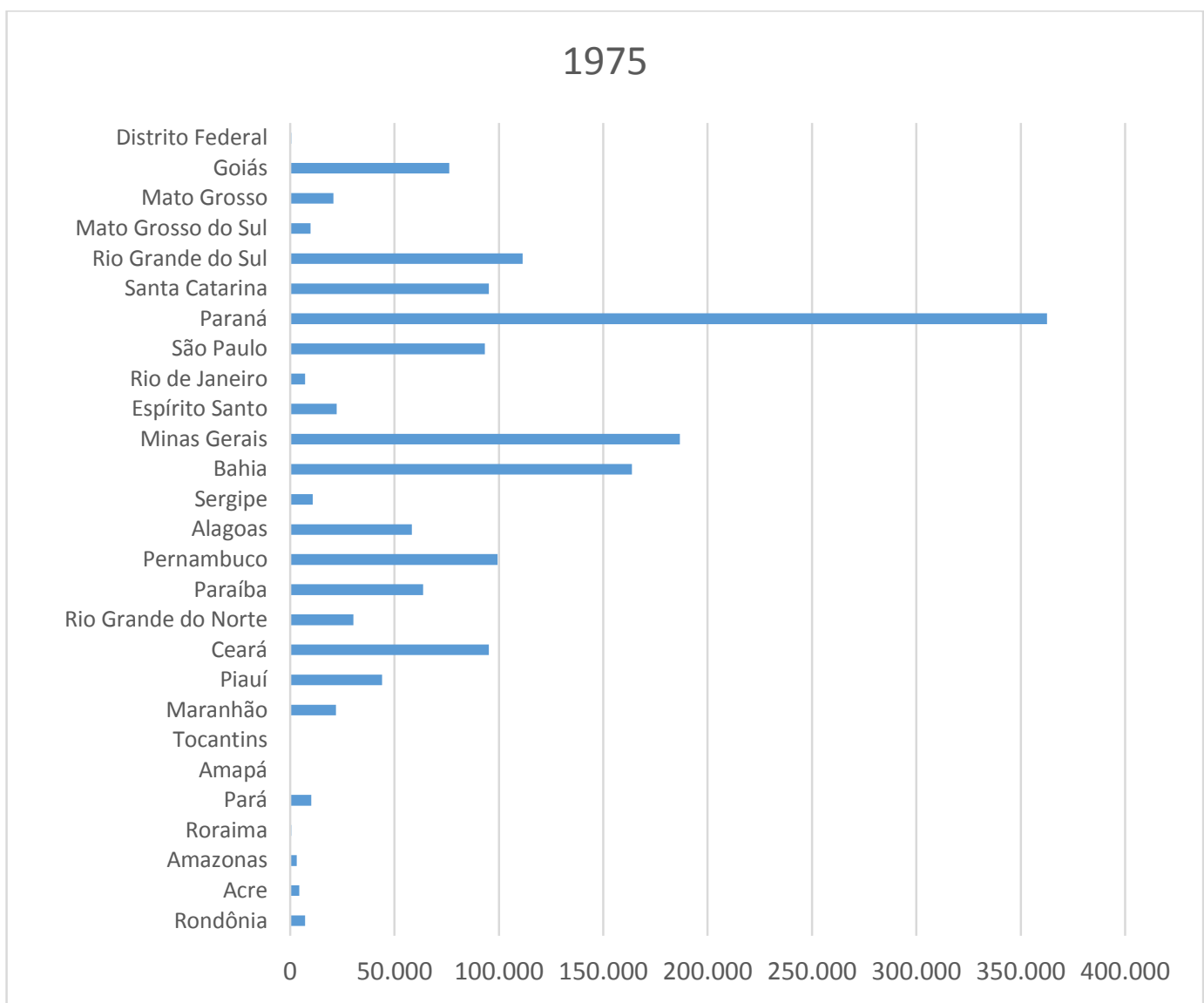

Gráfico 02: Produção de feijão em 1975 (em toneladas)

Em 1980 o Nordeste sofre uma queda, mesmo que o principal estado produtor dessa região, a Bahia, tenha aumentado a produção. O Sudeste tem uma alta expressiva, passando o Nordeste em números. Isso porque São Paulo tem a produção dobrada nesses cinco anos e Minas Gerais também aumenta o plantio. Não encontramos trabalhos que analisem esse aumento vertiginoso da produção em São Paulo, mas uma hipótese e a propagação do cultivo de feijão-carioca, que produzo dobro dos outros feijões antes fortes nessa região, como o rosinha e o mulatinho ${ }^{160}$. 


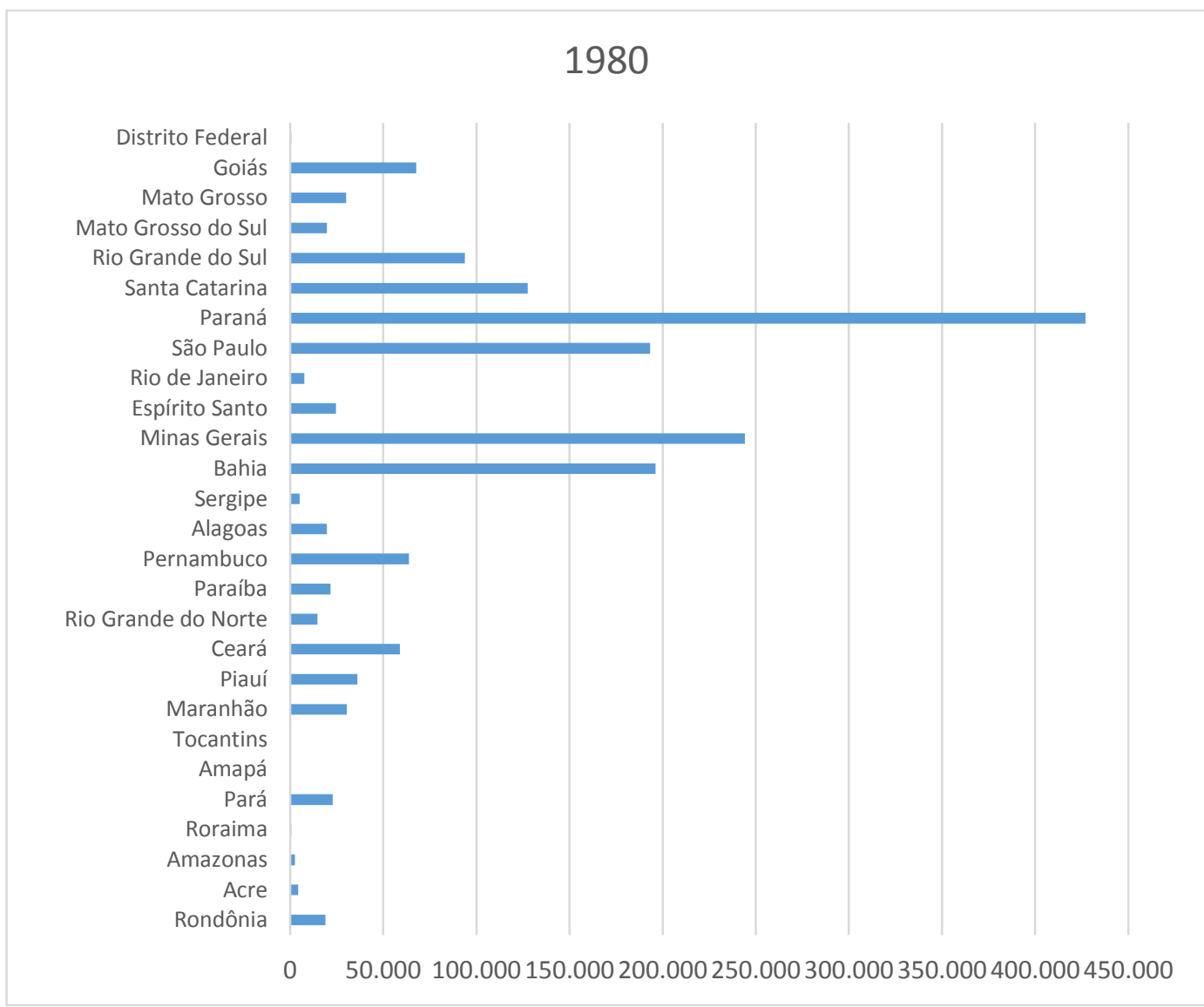

Gráfico 03: Produção de feijão em 1980 (em toneladas)

Leonardo Cunha Melo, coordenador do programa de melhoramento de feijão da Empresa Brasileira de Pesquisa Agropecuária (EMBRAPA), informa que o feijão-carioca surgiu na década de 70, entre 1974 e 1975, em uma propriedade rural de São Paulo. O agricultor observou que havia uma planta diferente que era muito mais produtiva, as vezes era capaz de produzir o dobro de outras variedades e tinha um grão bege com listras pretas. Provavelmente fruto de uma mutação genética, o grão foi levado a Instituto Agronômico de Campinas (IAC) para análise. O teste de panela e sabor foi bem sucedido, 0 feijão gerava um caldo mais grosso e era saboroso. O nome carioca, diz Luciano, vem de uma raça de porco caipira chamado carioca, bege com listras pretas, que teria inspirado o produtor. Essa é uma das versões. Porém, o novo tipo não foi aceito no mercado tão fácil. Somente algum tempo depois, sem exatidão quanto a data, quando a safra do feijão-rosinha foi ruim, ele entrou 
como seu substituto ${ }^{161}$. O mesmo ocorreu com o feijão-rajado, que também é uma variedade mais recente, porém de outra origem. O feijão-carioca, por ser pequeno, mesmo que sendo uma mutação genética ocorrida em São Paulo, tem suas origens mesoamericanas. Já o rajado, grão maior, vem dos Andes. Luciano diz que provavelmente ele é um melhoramento genético de variedades que antes eram conhecidas por outro nome, como o cavalo e o carnaval. ${ }^{162}$

De fato, ele demorou para entrar no mercado. Em reportagem do jornal Folha de São Paulo de 26 de janeiro de 1980, a declaração do setor de genética da IAC diz que trabalham com todos os grupos, "porém nós damos ênfase ao rosinha e ao roxinho, pela alta cotação no mercado e pela excelente qualidade culinária." 163 Em 22 de dezembro de 1982 há a notícia da segunda quebra da safra no mesmo ano, com $80 \%$ de perda da produção por causa das fortes chuvas em São Paulo ${ }^{164}$. Segundo a FAO ${ }^{165}$, 1983 foi o ano do nosso recorte em que menos se produziu, provavelmente devido a estes problemas nas safras. Os problemas não se concentraram no Sudeste. Com o autoconsumo alto, uma crise na produção representa o agravamento da fome, o que aconteceu no Nordeste ${ }^{166}$.

Camponeses famintos e desempregados saquearam um depósito de alimentos que estava guardado na maternidade de Águas Belas, de propriedade do Governo do Estado, dali retirando grande quantidade de arroz, feijão e farinha. (...) Águas Belas, que até bem pouco tempo era o maior produtor de feijão do Estado, não dispõe de um só quilo de produto atualmente, já que a seca destruiu toda a lavoura.

\footnotetext{
161 Entrevista concedida a pesquisadora, 27 de outubro de 2014.

162 Idem, ibidem.

163 "Combate às doenças do feijão". Folha de São Paulo, 26 de janeiro de 1980, Educação. p. 11.

164 "Quebra de 80\% na safra de feijão". Folha de São Paulo, 22 de dezembro de 1982, Economia. p. 19

165 Organização das Nações Unidas para Alimentação e Agricultura (FAO). Disponível em http://faostat.fao.org/site/354/default.aspx . Acessado 17.09.2014.

166 "Fome e desemprego provocam mais uma invasão no Nordeste". Folha de São Paulo, 30 de julho de 1983. Folha Agrícola. p. 21.
} 
Claro que a crise afetou no preço, que foi o maior responsável pela alta do valor do alimento. Aos poucos, o feijão-carioca começa a aparecer nas políticas para conter a crise ${ }^{167}$ :

A partir da próxima semana as agências bancárias dos municípios produtores de feijão vão liberar recursos da Companhia de Financiamento da Produção (CFP), para formação de estoques de produção (EGFS) e compras do produto, pelo governo (AGFS). O feijão anão - das variedades preto, carioca, carioquinha, bico de ouro, rosinha, jalo, rajado, roxo, roxinho, roxão e mulatinho - terá o preço básico para compras pela CFP (tipo 3) de Cr\$20.457 o saco de $60 \mathrm{~kg}$, livre de despesas, inclusive embalagem.

Pouco tempo depois, em uma matéria de 1984 o feijão-carioca já aparece como referencial de preço e com o menor deles. Durante a crise da produção, o feijão mais barato se torna presente na mesa do brasileiro ${ }^{168}$ :

O presidente da Bolsa de Cereais disse que provavelmente 0 governo ainda tem um estoque de cerca de 200 mil toneladas de feijão da safra passada, que poderão ser comercializadas a preços mais acessíveis ao consumidor, o qual hoje está pagando mais de Cr\$1.300 o quilo do feijão rosinha -o preço varia até mais de Cr\$1.700 cerca de Cr\$ 1.100 o feijão carioca, enquanto o feijão roxinho vai de $\operatorname{Cr} \$ 1.600$ a $\operatorname{Cr} \$ 1.950$ o quilo.

Aos poucos, a produção do feijão-carioca aumenta. Ainda no contexto da crise, em Santa Catarina, onde os problemas com as pragas e as chuvas não afetaram tanto a produção quanto no Paraná, o feijão-carioca já representava, em 1984, 35\% da plantação ${ }^{169}$. Precisamos lembrar que a região Sul predomina o plantio de feijão-preto, sendo esse percentual para o carioca muito significativo.

\footnotetext{
167 "Financiamento do feijão será liberado". Folha de São Paulo, 18 de novembro de 1983, Economia. p. 7.

168 "Denunciado alarmismo para aumentar feijão". Folha de São Paulo, 1 de fevereiro de 1984. Economia. p. 11.

169 "Colheita pequena no país". Folha de São Paulo, 22 de abril de 1984. Economia. p. 32.
} 


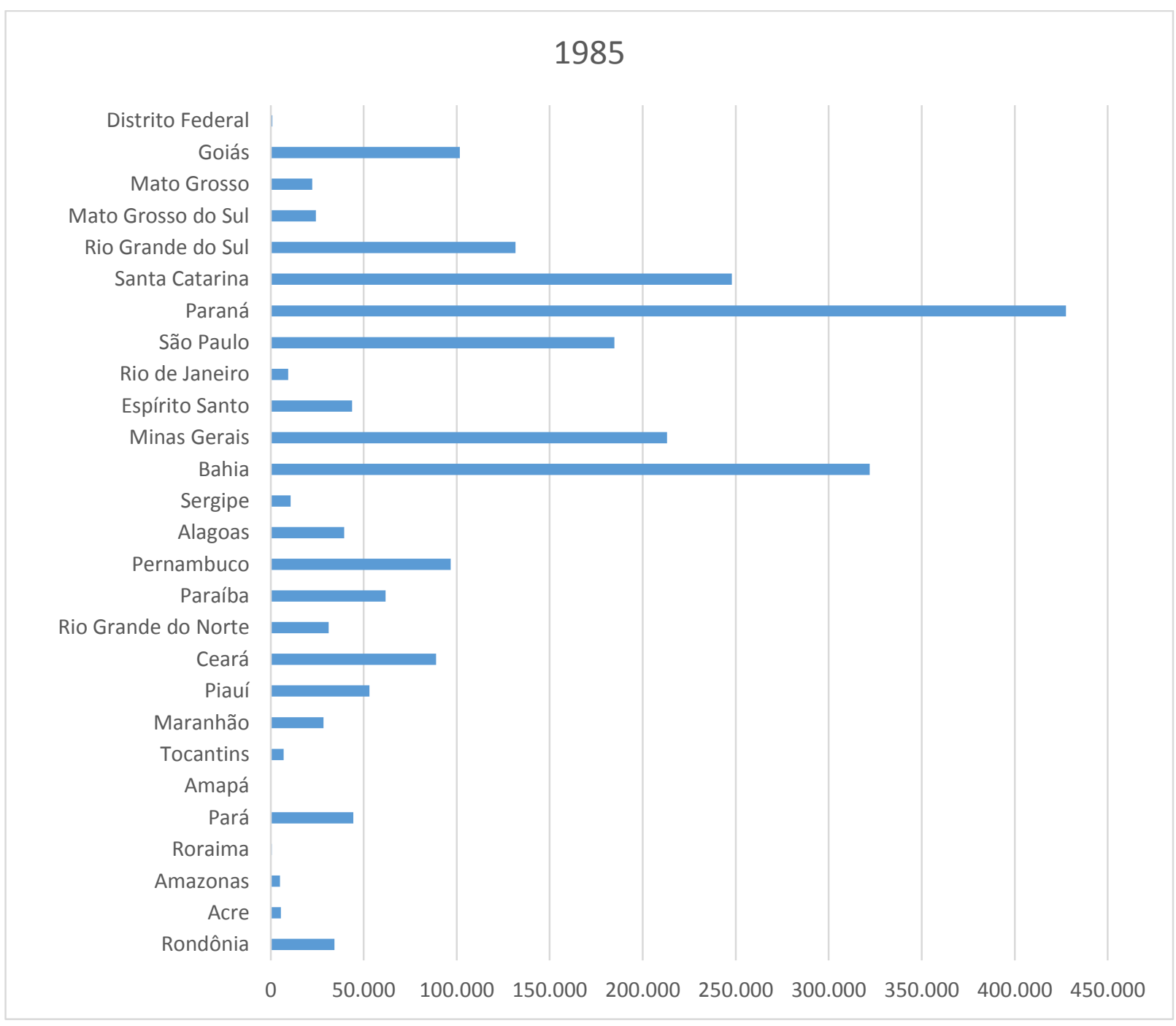

Gráfico 04: Produção de feijão em 1985 (em toneladas) ${ }^{170}$

O próximo Censo Agropecuário, de 1985, nos mostra que a alta produção mantém em São Paulo e Minas e que a Bahia tem um grande aumento, de $64 \%$. O Paraná continua como o maior estado produtor, levando a região Sul a grande fornecedora de feijão para o país. O Norte tem uma alta significativa, comparado com os outros anos, principalmente no Pará e em Rondônia.

O setor agrícola corresponde a uma parte importante do PIB, principalmente o agronegócio. Isso faz com que pequenas culturas não recebam muita atenção institucional. Produtos como a soja acabam tendo ${ }^{170}$ IBGE, Sistema IBGE de Recuperação Automática (SIDRA). Op. Cit. 
maior atenção governamental, deixando outros, como o feijão, marginalizados. A crise do feijão no início dos anos 80 denunciou este problema, tendo o seu preço ultrapassado o da carne ${ }^{171}$.

Numa investigação na principal região produtora de feijão do País, ao Sul de São Paulo, abrangendo os municípios de Itararé, Itaporanga, Riversul, Barão de Antonina, Sengés e Itaberá, responsável por cerca de $50 \%$ da produção do Estado e cerca de $30 \%$ da produção nacional, o que se descobriu não foram estoques secretos nas mãos de atravessadores ou em armazéns de produtores, mas sim o retrato de uma região decadente e empobrecida, onde se produz cada vez menos, $o$ comércio encolhe $e$ os pequenos agricultores, descapitalizados, engrossam os batalhões de bóias-frias que cada madrugada se agrupam nas saídas das cidades, procurando um trabalho cada vez mais escasso. Descobriu-se principalmente o abandono da região, que não conta com nenhuma infra-estrutura de estocagem, nenhum posto de produção de sementes, nenhum programa de incentivo ao plantio de feijão. (...) Uma região bem diferente do Norte do Paraná, tão próximo, onde a soja, o algodão e a cana, plantados com os olhos da exportação, vicejam (...). E que aponta como causa de sua decadência a mesma causa que, no fundo, é responsável pelos altos preços do feijão na mesa do brasileiro: uma política agrícola que não se preocupa com a produção de alimentos de consumo interno, que não faz estoques reguladores (...)

Em 1986 houve a criação do Ministério de Estado Extraordinário para Assuntos de Irrigação. A intenção era dar ênfase a este sistema para que aumentasse a produtividade entre os agricultores. Cogitou-se, nessa época, que o feijão seria incorporado à grande produção, saindo dos pequenos agricultores e passando para o sistema empresarial. Para as ações, foi criado o Plano Nacional de Irrigação, com o objetivo de aumentar a área irrigada no país em $120 \%$ nos cinco anos seguintes. A meta não foi cumprida e, em 1988,

171 "Produtor culpa política agrícola por feijão caro". Folha de São Paulo, 22 de abril de 1984. Economia. p. 32. 
o Ministério foi extinto e o assunto transferido para a Secretaria de Assuntos de Irrigação, braço do Ministério da Agricultura. Em 1999 o tema passa a ser responsabilidade do Ministério da Integração Nacional e em alguns casos do MAPA, Ministério da Agricultura, Pecuária e Abastecimento. A questão relevante na época da criação do Ministério voltado para irrigação era a possibilidade, para os produtores de feijão, com o sistema de irrigação, de o produto passar a ter a quarta safra e assim, aumentar a produtividade. No geral ele mantém três safras anuais: safra das águas, safra da seca e safra do outono inverno ${ }^{172}$. A maioria dos produtores, durante o período da pesquisa, não usam sistema de irrigação nem agrotóxicos ${ }^{173}$.

A alta vulnerabilidade da plantação de feijão pode ser sentida na grande variabilidade dos preços que continua frequente. Em 1990 uma geada acabou com pelo menos $20 \%$ da produção de feijão, noticia o jornal Folha de São Paulo. "No mercado atacadista de São Paulo, a saca de carioca extra, que no início do ano era comercializada a NCz\$400, chegou a NCz\$ 650 na última sexta-feira." 174

Em 1995, no Censo que o gráfico mostra a seguir, apesar de o Paraná continuar sendo o principal produtor, o Nordeste é a região fundamental pela produção mais disseminada entre os estados. Goiás, que já teve um aumento em 1985 mantém uma produção expressiva no Centro-Oeste. O Sudeste vem, desde o Censo anterior, com uma pequena queda na produção.

172 SALVADOR, Carlos Alberto. "Análise da conjuntura agropecuária, safra 2011/2012 - feijão". Estado do Paraná - Secretaria da Agricultura e do Abastecimento, Departamento de Economia Rural.

173 Empresa Brasileira de Pesquisa Agropecuária (Embrapa). Op. Cit.

174 "Chuvas derrubam em pelo menos $20 \%$ a primeira colheita de feijão". Folha de São Paulo, 16 de janeiro de 1990, Agrofolha. p. 3. 


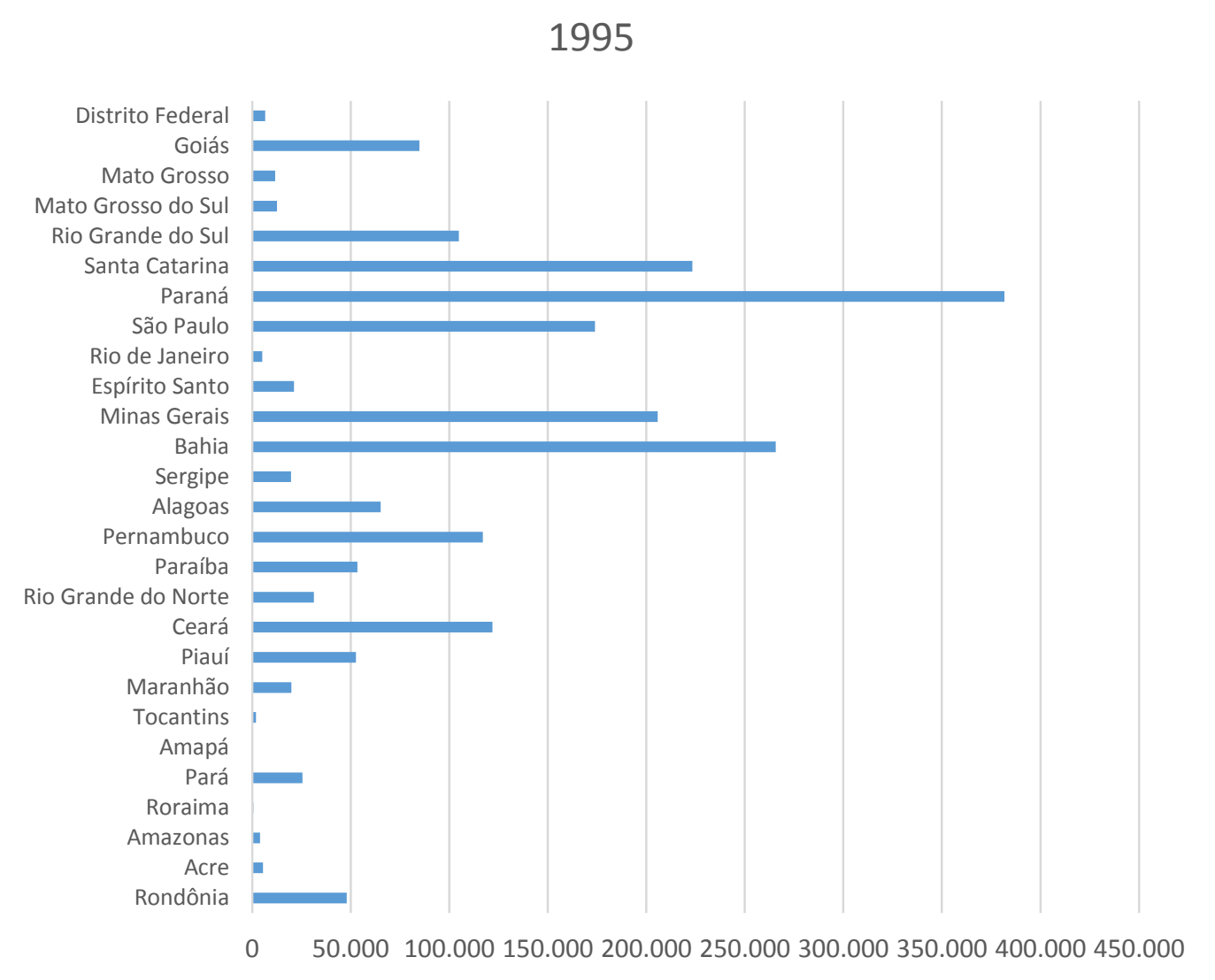

Gráfico 05: Produção de feijão em 1995 (em toneladas) ${ }^{175}$

175 IBGE, Sistema IBGE de Recuperação Automática (SIDRA). Op. Cit. 


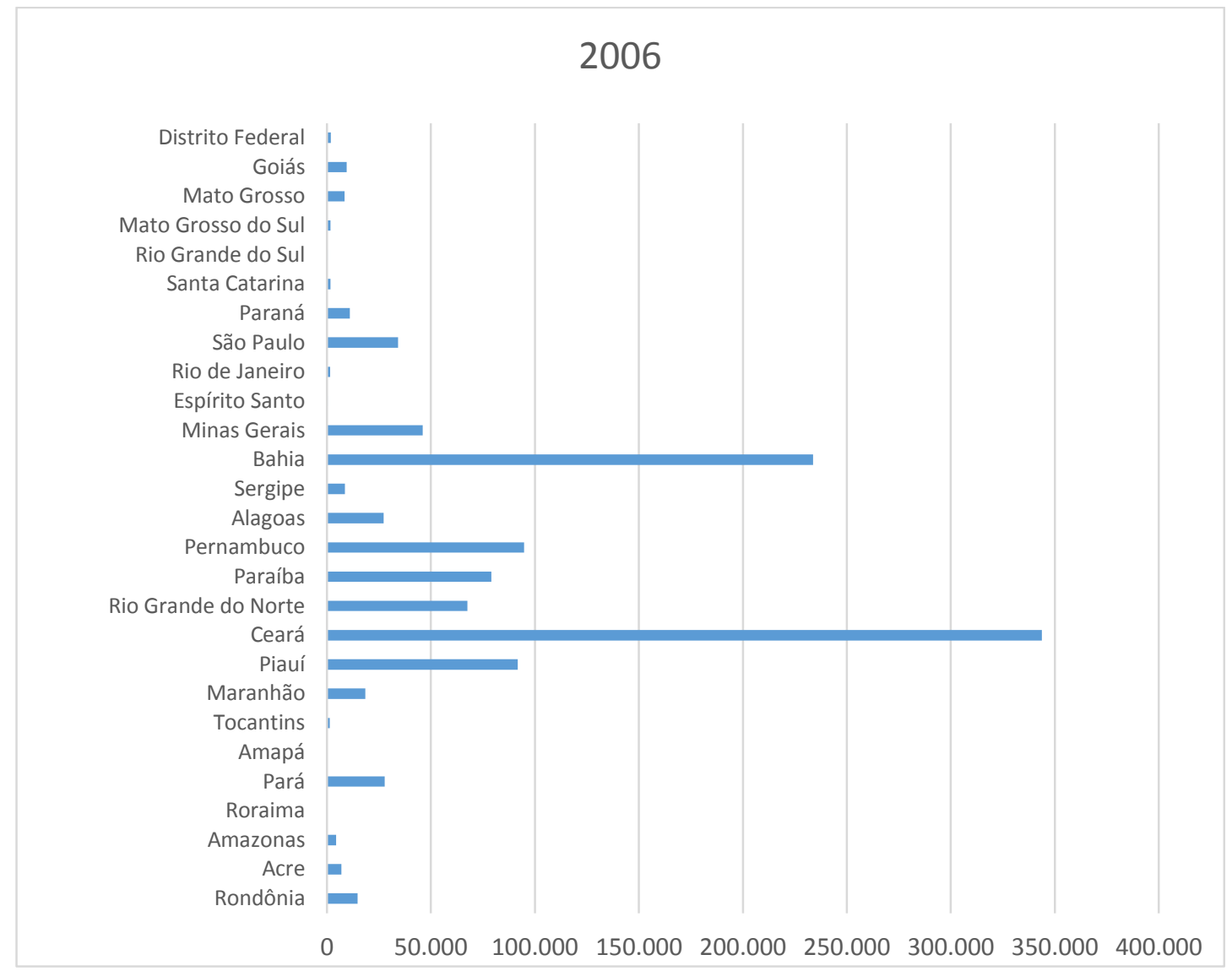

Gráfico 06: Produção de feijão em 2006 (em toneladas) ${ }^{176}$

Em 2006, como mostra o gráfico acima feito a partir dos dados do Censo Agropecuário do IBGE disponível na base de dados SIDRA, há uma abrupta queda da produção no Sul, Sudeste e Centro-Oeste se comparado com os anos anteriores. Paraná aparenta ter um decréscimo de $98 \%$. Procurando os motivos para tal queda, não encontramos nenhum trabalho ou matéria na imprensa que tratasse do tema, como as reportagens que relatam a queda da produção. Por isso, optamos por comparar os dados do IBGE com outras fontes que medem a produção agrícola brasileira, como a Companhia Nacional de Abastecimento, CONAB ${ }^{177}$ ou mesmo a publicação do IBGE para o Censo Agropecuário de 2006. A CONAB disponibiliza séries históricas desde 1976 e os dados para 2006 são bem díspares dos do IBGE:

176 IBGE, Sistema IBGE de Recuperação Automática (SIDRA). Op. Cit.

177 Companhia Nacional de Abastecimento (CONAB). Séries Históricas. Disponível em: http://www.conab.gov.br/conteudos.php?a $=1252 \& t=2 \& P a g i n a ~ o b j c m s c o n t e u d o s=2 \# A$ objcmsc onteudos Acessado 08/11/2014. 
Tabela 04: Produção de feijão - 1ํㅜㄴ $2^{\circ}$ e $3^{\circ}$ Safra. (em mil toneladas)

\begin{tabular}{|l|r|r|}
\hline Região/UF & $\mathbf{2 0 0 5 / 0 6}$ & $\mathbf{2 0 0 6 / 0 7}$ \\
\hline Norte & 121,2 & 136,6 \\
\hline Roraima & 0,9 & 0,7 \\
\hline Rondônia & 35,4 & 41,2 \\
\hline Acre & 8,7 & 8,2 \\
\hline Amazonas & 3,7 & 6,0 \\
\hline Amapá & 0,6 & 1,1 \\
\hline Pará & 62,0 & 67,5 \\
\hline Tocantins & 9,9 & 11,9 \\
\hline Nordeste & $1.091,6$ & 801,4 \\
\hline Maranhão & 38,1 & 39,5 \\
\hline Piauí & 95,8 & 42,0 \\
\hline Ceará & 258,3 & 124,6 \\
\hline Rio Grande do & 37,1 & 32,1 \\
Norte & 118,4 & 49,3 \\
\hline Paraíba & 129,8 & 114,2 \\
\hline Pernambuco & 52,2 & 47,6 \\
\hline Alagoas & 24,9 & 29,5 \\
\hline Sergipe & 337,0 & 322,6 \\
\hline Bahia & 396,0 & 411,4 \\
\hline Centro Oeste & 45,8 & 67,1 \\
\hline Mato Grosso & 29,0 & 26,6 \\
\hline Mato Grosso do & 286,9 & 271,4 \\
\hline Sul & 34,3 & 46,3 \\
\hline Goiás & 847,8 & 839,8 \\
\hline Distrito Federal & 536,6 & 503,5 \\
\hline Sudeste & 18,3 & 16,7 \\
\hline Minas Gerais & 5,8 & 5,7 \\
\hline Espírito Santo & 287,1 & 313,9 \\
\hline Rio de Janeiro & $1.014,6$ & $1.150,5$ \\
\hline São Paulo & 743,5 & 795,3 \\
\hline Sul & 155,4 & 208,9 \\
\hline Paraná & 115,7 & 146,3 \\
\hline Santa Catarina & \\
\hline Rio Grande do & & \\
Sul & & \\
\hline
\end{tabular}

A CONAB separa a tabela pelas safras $\left(1^{\circ}, 2^{\circ}\right.$ e $\left.3^{\circ}\right)$, não por ano. De forma geral, os dados desse órgão são ligeiramente distintos dos do IBGE, mas podemos perceber que eles não detectam uma queda radical na produção e sim uma alta, assim como faz os dados da FAO, na tabela a seguir. Por isso, concluímos que provavelmente há um problema com a apresentação dos 
dados do Censo Agropecuário de 2006 apresentados no SIDRA já que mesmo a publicação do Censo Agropecuário apresenta outros números. Os dados coletados pela FAO também diferem um pouco dos outros dois, CONAB e IBGE, mesmo sendo similares. Percebemos, analisando as outras fontes que, ao contrário do que mostra o SIDRA, o Paraná permanece como o grande estado produtor, sendo a região Sul e depois a Sudeste como os maiores polos de feijão no país.

A agricultura familiar ${ }^{178}$ continua representando o maior percentual responsável pela produção de feijão no país, chegando a $70 \%{ }^{179}$. autoconsumo detém $27,64 \%$ deste alimento ${ }^{180}$. A irrigação continua sem participação alguma na plantação, apenas em 2,6\% dos estabelecimentos. Porém a adubação química esteve presente em $60,2 \%$ da produção e a aplicação de agrotóxico em $29,6 \%{ }^{181}$.

Tabela 05: Produção, importação e disponibilidade para alimentação (em toneladas) ${ }^{182}$

\begin{tabular}{|c|c|c|c|c|}
\hline Ano & Produção (t) & Importação (t) & $\begin{array}{c}\text { \%Importação/ } \\
\text { produção }\end{array}$ & $\begin{array}{c}\text { Disponibilidade para } \\
\text { alimentação (t) }\end{array}$ \\
\hline 1973 & 2.232 .033 & 13.893 & $0,62 \%$ & 2.006 .973 \\
\hline 1974 & 2.238 .012 & 1.431 & $0,06 \%$ & 2.004 .096 \\
\hline 1975 & 2.282 .466 & 3.705 & $0,16 \%$ & 1.999 .447 \\
\hline 1976 & 1.840 .315 & 52.734 & $2,87 \%$ & 1.654 .197 \\
\hline 1977 & 2.290 .007 & 81.819 & $3,57 \%$ & 1.815 .963 \\
\hline 1978 & 2.193 .977 & 7.580 & $0,35 \%$ & 1.867 .011 \\
\hline 1979 & 2.186 .343 & 7.664 & $0,35 \%$ & 1.888 .357 \\
\hline 1980 & 1.968 .165 & 39.887 & $2,03 \%$ & 1.890 .512 \\
\hline 1981 & 2.340 .947 & 5.631 & $0,24 \%$ & 1.989 .118 \\
\hline
\end{tabular}

178 Apesar de alguns estudos terem tratado sobre o conceito de Agricultura Familiar, a lei de 2006 define o recorte para a efetivação do Plano Nacional da Agricultura Familiar. Na Lei no 11.326, de 24 de julho de 2006, a agricultura familiar foi assim definida: Art. 3ํㅜ Para os efeitos desta Lei, considera-se agricultor familiar e empreendedor familiar rural aquele que pratica atividades no meio rural, atendendo, simultaneamente, aos seguintes requisitos:

I - não detenha, a qualquer título, área maior do que 4 (quatro) módulos fiscais;

II - utilize predominantemente mão de obra da própria família nas atividades econômicas do seu estabelecimento ou empreendimento;

III - tenha renda familiar predominantemente originada de atividades econômicas vinculadas ao próprio estabelecimento ou empreendimento;

IV - dirija seu estabelecimento ou empreendimento com sua família.

IBGE, Censo Agropecuário 2006 Agricultura familiar Primeiros resultados. Rio de Janeiro: 2007. p. 39.

179 IBGE, Censo Agropecuário 2006. Agricultura familiar: Primeiros resultados. Op. Cit. p. 19.

180 IBGE, Censo Agropecuário 2006. Op. Cit.

181 IBGE, Censo Agropecuário 2006 - Comentários. Rio de Janeiro 2006. p. 149.

182 Organização das Nações Unidas para Alimentação e Agricultura (FAO). Op. Cit. 


\begin{tabular}{|c|c|c|c|c|}
\hline 1982 & 2.902 .657 & 3.570 & $0,12 \%$ & 2.099 .822 \\
\hline 1983 & 1.580 .546 & 3.739 & $0,24 \%$ & 2.182 .014 \\
\hline 1984 & 2.625 .676 & 60.527 & $2,31 \%$ & 2.187 .349 \\
\hline 1985 & 2.548 .738 & 15.343 & $0,60 \%$ & 2.108 .095 \\
\hline 1986 & 2.219 .478 & 94.999 & $4,28 \%$ & 2.018 .368 \\
\hline 1987 & 2.006 .055 & 35.054 & $1,75 \%$ & 2.052 .001 \\
\hline 1988 & 2.802 .983 & 30.619 & $1,09 \%$ & 2.022 .336 \\
\hline 1989 & 2.308 .355 & 42.798 & $1,85 \%$ & 2.067 .072 \\
\hline 1990 & 2.234 .467 & 70.401 & $3,15 \%$ & 2.006 .119 \\
\hline 1991 & 2.744 .711 & 96.782 & $3,53 \%$ & 2.334 .250 \\
\hline 1992 & 2.797 .138 & 96.657 & $3,46 \%$ & 2.418 .495 \\
\hline 1993 & 2.478 .325 & 79.821 & $3,22 \%$ & 2.639 .642 \\
\hline 1994 & 3.369 .684 & 219.002 & $6,50 \%$ & 2.765 .990 \\
\hline 1995 & 2.946 .168 & 171.762 & $5,83 \%$ & 2.143 .562 \\
\hline 1996 & 2.449 .396 & 82.413 & $3,36 \%$ & 3.143 .120 \\
\hline 1997 & 2.840 .243 & 158.474 & $5,58 \%$ & 2.488 .158 \\
\hline 1998 & 2.191 .153 & 211.030 & $9,63 \%$ & 2.587 .661 \\
\hline 1999 & 2.830 .915 & 92.808 & $3,28 \%$ & 2.655 .816 \\
\hline 2000 & 3.038 .238 & 79.528 & $2,62 \%$ & 2.864 .287 \\
\hline 2001 & 2.453 .420 & 130.263 & $5,31 \%$ & 2.912 .981 \\
\hline 2002 & 3.064 .230 & 82.303 & $2,69 \%$ & 2.860 .810 \\
\hline 2003 & 3.302 .038 & 103.277 & $3,13 \%$ & 3.127 .440 \\
\hline 2004 & 2.967 .007 & 79.191 & $2,67 \%$ & 2.794 .182 \\
\hline 2005 & 3.021 .641 & 100.697 & $3,33 \%$ & 2.856 .644 \\
\hline 2006 & 3.457 .744 & 70.064 & $2,03 \%$ & 3.055 .167 \\
\hline 2007 & 3.169 .360 & 96.269 & $3,04 \%$ & 3.075 .112 \\
\hline 2008 & 3.461 .194 & 209.690 & $6,06 \%$ & 3.137 .684 \\
\hline 2009 & 3.486 .763 & 109.921 & $3,15 \%$ & 3.154 .548 \\
\hline 2010 & 3.158 .905 & 181.162 & $5,73 \%$ & 3.176 .246 \\
\hline
\end{tabular}

Um dos itens da tabela que a FAO divulga é a disponibilidade de feijão para alimentação. Este item é definido pelo órgão da ONU como a quantidade total da commodity que está disponível para alimentação humana dentro do período proposto, sem contar as sementes que voltam para o plantio e a parte exportada e é somada a parte importada para consumo. Os números incluem também a commodity mais qualquer derivação dela resultado de algum processamento ${ }^{183}$. Para nossa análise esses valores são fundamentais, já que alguma parte da produção é desperdiçada, ou adquire outra função, como a volta da semente para o plantio. Vemos, de forma geral, o aumento da disponibilidade de feijão, como mostra o gráfico posterior. Os dados são 183 Organização das Nações Unidas para Alimentação e Agricultura (FAO). Op. Cit. 
apresentados como números em absoluto, isso quer dizer, sem o consumo per capita, o que não conta o crescimento da população e não mede o real consumo.

Como podemos ver pela tabela anterior com os dados da FAO, o Brasil importou feijão durante todo o período a pesquisa, não sendo, em nenhum momento, autossuficiente. Porém, como demonstra a estatística, esse número varia muito. A porcentagem da importação em relação a produção nacional pode ser de 0,06\%, quase inexistente, como em 1974, como 9,63\%, em 1998. Nota-se, neste último, que foi um ano ruim para a produção, com 2.191.153 de toneladas, número menor que no ano anterior, 2.840.243 de toneladas. Porém essa ligação entre queda da safra e importação não tem uma relação linear, como podemos ver no ano de 1983, pior safra do recorte temporal em que as importações corresponderam a apenas $0,24 \%$ da produção nacional. 

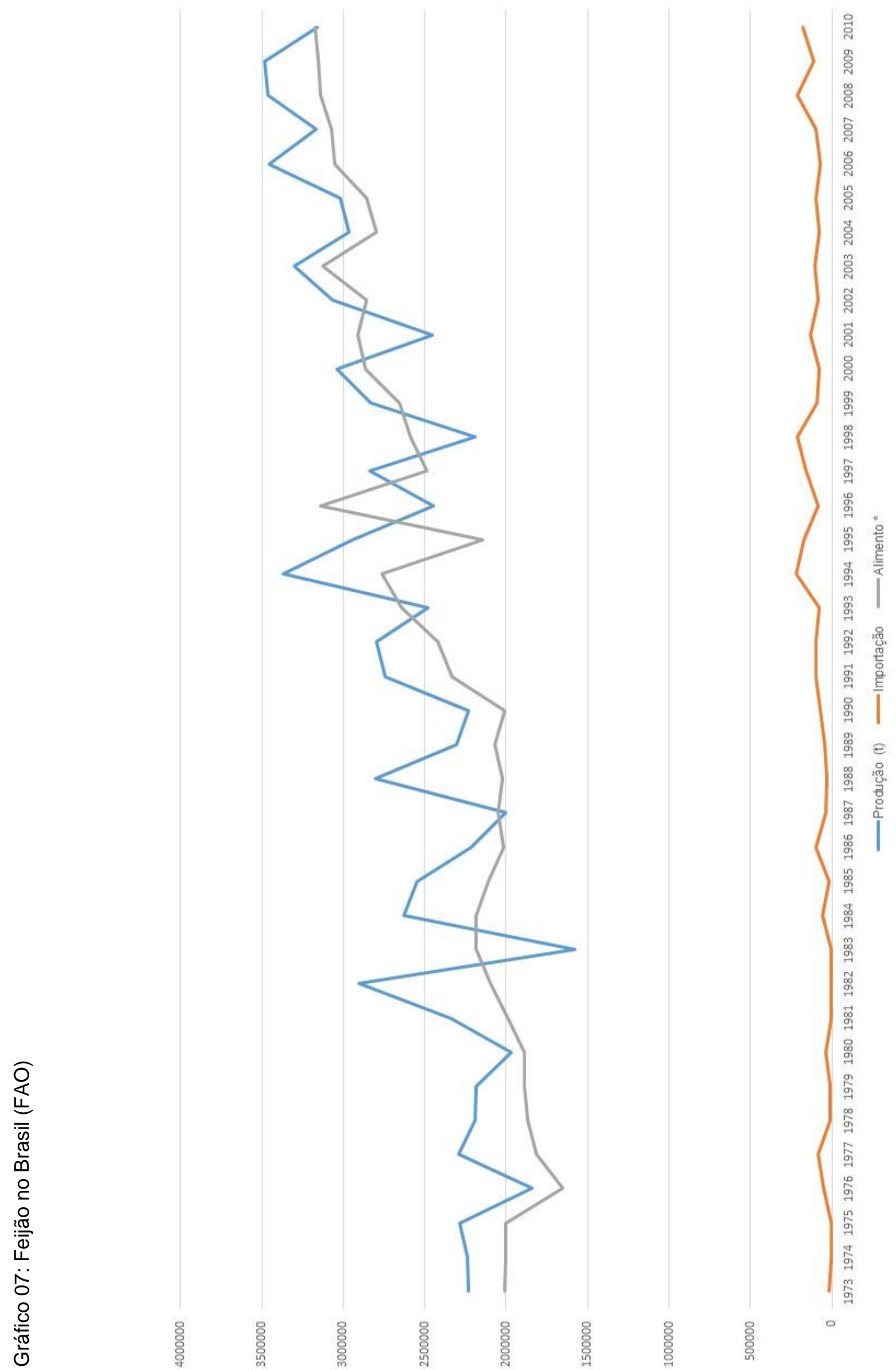
A maioria das importações de feijão até os anos 90 feita pelo Brasil vinha do Mercosul, dos Estados Unidos e do México. Argentina é o país que mais fornece, com $80 \%$ do produto, principalmente feijão preto ${ }^{184}$. A China entrou como grande protagonista no final do período, se tornando um importante país fornecedor de feijão, principalmente depois de 2008, quando as safras do Brasil e da Argentina foram ruins ${ }^{185}$. A tabela com os dados da FAO mostra que, neste ano, o percentual importado pelo Brasil representou 6,06\%, valor bem acima da média que é de 2,89\%. Em 2008 a China se tornou o maior exportador mundial de feijão, chegando a vender 960mil toneladas do alimento, confirmando essa posição no ano seguinte, com a cifra de 1.046 mil toneladas ${ }^{186}$.

'Nossa preferência sempre foi pelo feijão-preto produzido aqui, onde tivemos ótimas safras', afirma o diretor da Broto Legal Alimentos, Hugo Fujisawa. Ele conta que cinco anos atrás (2008) a Argentina dominava as exportações para o Brasil. Aproveitando a quebra de safra nacional e falta de competitividade do feijão argentino, o grão chinês começou a ser testado pelos empacotadores. O baixo custo, o dólar favorável à importação e a qualidade aperfeiçoada transformaram o grão chinês em rival imbatível diante do feijãopreto brasileiro e do argentino, explica.

Argentina e China fornecem quase a totalidade de feijões importados para o país. Comparado com outros países, o Brasil não é o maior importador do produto, ele fica atrás de outros como a Índia, Reino Unido, Estados Unidos e Japão, por exemplo ${ }^{187}$.

184 FERREIRA, Carlos Magri et.al. "Aspectos econômicos". In: VIEIRA, Clibas, JUNIOR, Trazilbo \& BORÉM, Aluízio (Ed.). Feijão. Viçosa: EFV, 2006. p 26.

185 Agência Estado. "Brasil importa até feijão-preto da China". Disponível em: http://economia.ig.com.br/2012-06-10/brasil-importa-ate-feijao-preto-da-china.html acessado em 10.10.2014.

186 CHIARA, Marcia de. "Brasil importa até feijão-preto da China". O Estado de São Paulo, Economia. 12 de junho de 2012.

187 Organização das Nações Unidas para Alimentação e Agricultura (FAO). Op. Cit. 
Durante o período da pesquisa o Brasil não exportou grandes quantidades de feijão, comercializando principalmente com África do Sul, Estados Unidos e Japão em quantidades mínimas.

Tabela 06: Comparação da produção de feijão com outros países (toneladas) ${ }^{188}$

\begin{tabular}{|c|c|c|c|c|c|}
\hline Ano & Brasil & Índia & México & China & $\begin{array}{c}\text { Estados } \\
\text { Unidos }\end{array}$ \\
\hline 1973 & 2006973 & 2178647 & 810867 & 1508597 & 706000 \\
\hline 1974 & 2004096 & 1715588 & 827452 & 1522841 & 522000 \\
\hline 1975 & 1999447 & 2270856 & 835456 & 1514971 & 665000 \\
\hline 1976 & 1654197 & 1991532 & 725868 & 1458585 & 629000 \\
\hline 1977 & 1815963 & 2248764 & 762369 & 1432965 & 650000 \\
\hline 1978 & 1867011 & 2101430 & 717759 & 1518915 & 521000 \\
\hline 1979 & 1888357 & 1578857 & 697030 & 1525527 & 660000 \\
\hline 1980 & 1890512 & 2276117 & 1236128 & 1567996 & 558000 \\
\hline 1981 & 1989118 & 2605062 & 1646370 & 1554956 & 563000 \\
\hline 1982 & 2099822 & 2372185 & 1076658 & 1598980 & 685000 \\
\hline 1983 & 2182014 & 3035486 & 1242768 & 1567939 & 691000 \\
\hline 1984 & 2187349 & 2675592 & 804661 & 1601274 & 547000 \\
\hline 1985 & 2108095 & 2687861 & 966530 & 1506880 & 768000 \\
\hline 1986 & 2018368 & 3038416 & 1131549 & 941161 & 721000 \\
\hline 1987 & 2052001 & 2828958 & 939636 & 1057234 & 573000 \\
\hline 1988 & 2022336 & 3514919 & 798043 & 1133828 & 767000 \\
\hline 1989 & 2067072 & 3308994 & 599289 & 1017519 & 662000 \\
\hline 1990 & 2006119 & 3564902 & 910768 & 646868 & 748000 \\
\hline 1991 & 2334250 & 3021087 & 1052923 & 472950 & 850000 \\
\hline 1992 & 2418495 & 3288367 & 965118 & 382381 & 906000 \\
\hline 1993 & 2639642 & 2778434 & 922511 & 561778 & 880000 \\
\hline 1994 & 2765990 & 2647808 & 951179 & 389236 & 935800 \\
\hline 1995 & 2143562 & 2962398 & 1255331 & 424514 & 932500 \\
\hline 1996 & 3143120 & 3003388 & 1148280 & 438561 & 916600 \\
\hline 1997 & 2488158 & 2571920 & 1335407 & 528597 & 936900 \\
\hline 1998 & 2587661 & 2236283 & 1182666 & 528793 & 919800 \\
\hline 1999 & 2655816 & 2468098 & 1036470 & 487545 & 989800 \\
\hline 2000 & 2864287 & 2449262 & 1080536 & 500161 & 890000 \\
\hline 2001 & 2912981 & 2912281 & 1040977 & 429625 & 850000 \\
\hline 2002 & 2860810 & 2330132 & 1120745 & 444037 & 890000 \\
\hline 2003 & 3127440 & 4023950 & 1174032 & 320439 & 860000 \\
\hline 2004 & 2794182 & 2635448 & 1170978 & 246749 & 820000 \\
\hline 2005 & 2856644 & 2406922 & 1098428 & 229021 & 880000 \\
\hline 2006 & 3055167 & 3235426 & 1139451 & 237759 & 880000 \\
\hline 2007 & 3075112 & 3772224 & 1145540 & 307360 & 910000 \\
\hline & & & & & \\
\hline
\end{tabular}

188 Idem, ibidem. 


\begin{tabular}{|l|l|l|l|l|l|}
2008 & 3137684 & 3108568 & 1132076 & 196577 & 920000 \\
\hline 2009 & 3154548 & 2819550 & 1136350 & 176218 & 920000 \\
\hline 2010 & 3176246 & 4515868 & 1220101 & 185915 & 920000 \\
\hline
\end{tabular}

Segundo os dados da FAO, o Brasil não é o maior produtor mundial de feijão durante essa série histórica, esse posto pertence a Índia. Não podemos dizer que a Índia é o maior consumidor de feijão per capita no mundo, pelo tamanho de sua população. De fato, não é. Feijão, Phaseolus vulgaris L., é o alimento mais importante para o consumo direto no mundo, de acordo com a FAO, e sua principal região de consumido é nos grandes lagos africanos onde ficam países como Etiópia, Quênia, Tanzânia, Uganda, Ruanda, entre outros. Aqui ele é o alimento fundamental, fornecedor de calorias e proteína, tendo como associado em segundo plano o milho. Nesses locais o consumo per capita durante o período da pesquisa é, em média, de $50 \mathrm{~kg}$ por habitante em um ano, podendo chegar a $66 \mathrm{~kg} / \mathrm{ano}$, em cidades como Kisii, a área rural mais populosa do Quênia ${ }^{189}$. Essa média está muito acima da brasileira, como veremos no capítulo quatro.

A associação com o milho não é apenas para o fornecimento de uma alimentação mais completa, ela está também na plantação, em um sistema que os pré-colombianos denominavam como Milpa, plantio consorciado de feijão milho e as vezes abóbora. Provavelmente foram os portugueses que levaram essas duas plantas à região africana, onde encontrou ampla aceitação, se tornando a associação essencial nessas terras.

189 JONES, A. L. Phaseolus Bean: Post-harvest Operation. Centro Internacional de Agricultura Tropical, FAO. 1999. 


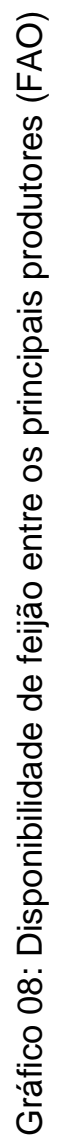

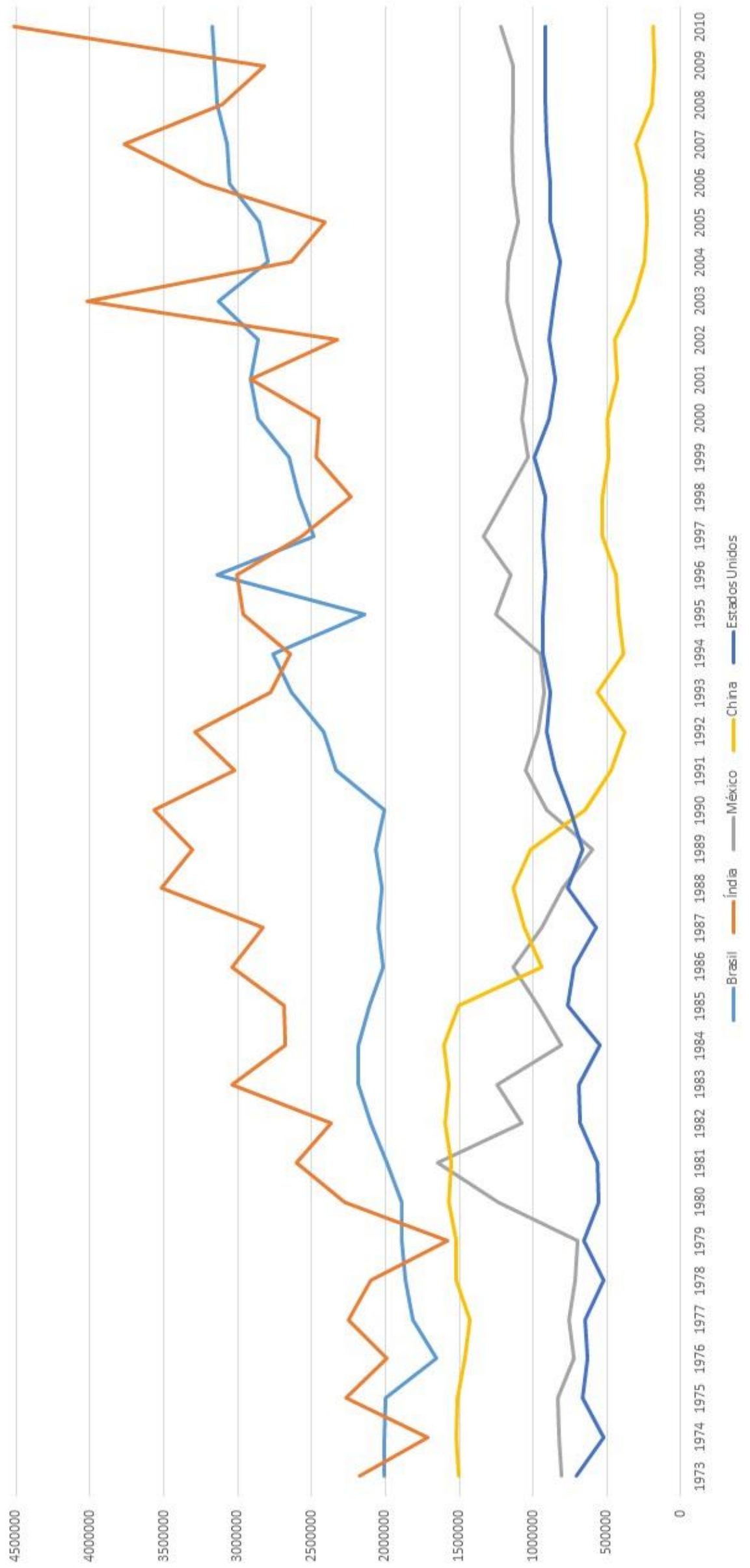




\section{Capítulo 03}

\section{O IBGE e as pesquisas alimentares}

Manifestado não apenas nas políticas públicas, mas também nas artes plásticas, literatura, produções acadêmicas e outras áreas, o desejo de entender e retratar o Brasil já foi estudo a partir de diversos ângulos. Porém, se por um lado, no campo da alimentação ele ainda carece de alguns esclarecimentos sob a ótica das Ciências Sociais, muito incipientes também são os trabalhos históricos que tratam das pesquisas quantitativas. Um dos elementos mais importantes das pesquisas quantitativas é a sua capacidade de compará-las ao longo do tempo, principalmente no que tange à análise histórica, chamada de História Serial-quantitativa. Essa seria a história econômica e demográfica que ao longo de um período é capaz de entender mudanças e permanências ocorridas a partir de dados seriados que apresentam certa homogeneidade, como a obra de Ernest Labrousse ${ }^{190}$.

Por isso, pretendemos analisar o contexto do surgimento do Instituto Brasileiro de Geografia e Estatística (IBGE) e suas grandes pesquisas sobre consumo alimentar e perfil nutricional, o Estudo Nacional da Despesa Familiar (ENDEF), e as Pesquisas de Orçamentos Familiares (POF). Interpretaremos seus resultados a partir do contexto e como eles foram entendidos para 0 projeto da construção do Brasil à mesa. Este capítulo contém trechos do artigo apresentado na ANPUH 2014 com o título: "ENDEF e o IBGE: pesquisas alimentares dentro do projeto da nação Brasil".

\subsection{O surgimento do IBGE}

\footnotetext{
190 Entre suas obras, podemos citar: Esquisse du mouvement de prix et de revenus en France au XVIII siècle. Paris: Librarie Dalloz, 1933 e La crise de l'économie française à la fin d'Ancient Régime et au début de la Revolution. Paris: PUF, 1944.
} 
Os dados seriados são importantes para entender as permanências, transformações e comportamentos sociais, porém esses indicadores quantitativos receberam pouca atenção histórica. Podemos destacar neste campo o trabalho do historiador Eduard Thompson, em seu livro, $A$ formação da classe operária inglesa, principalmente no volume II. Para ele, os principais meios para conhecer os padrões de vida do proletariado eram indicadores de hábitos alimentares, habitação ou vestimentas. "Thompson também chama atenção para a questão envolvida na dieta -ao mencionar, por exemplo, o caso dos trabalhadores rurais e mineiros e seus hábitos de ingestão de bebidas alcoólicas, em especial de cerveja 'essencial para o desempenho de qualquer trabalho pesado'"'191. Esses dados, usados como fontes históricas, são importantes meios para entender os costumes de uma sociedade, mas também para analisar os projetos envolvidos a partir dos resultados gerados, ou seja, como os governos e órgãos gestores se apropriaram essas informações. Segundo Jaime Rodrigues, muito do que se produziu olhando para as bases sociais procuraram, durante muito tempo, a homogeneidade e assim planos foram criados para direcionar padrões alimentares dessas bases ${ }^{192}$.

Para entendermos a pesquisa em questão, precisamos antes olhar para o Instituto Brasileiro de Geografia e Estatística, órgão responsável por ela. Sua criação é uma das consequências do processo de centralização, burocratização e racionalização do poder estatal durante o Estado Novo. Forjar a nação a partir de grandes regionalismos não era uma simples tarefa. "Em 1937 o Governo Vargas derruba as barreiras alfandegárias, queima, em cerimônia pública, no Rio de Janeiro, as bandeiras estaduais e brande o dístico: 'Grande só o Brasil'” 193. Esta centralização se explicita não apenas pela criação deste, mas de diversos órgãos federais, entre eles, o Conselho Nacional do Petróleo, Conselho Nacional de Águas e Energia Elétrica (1939), Conselho Nacional de Minas e Metalurgia e a Companhia Vale do Rio Doce

\footnotetext{
191 RODRIGUES, Jaime. Alimentação, vida material e privacidade. Uma história social de trabalhadores em São Paulo nas décadas de 1920-1960. São Paulo: Alameda, 2011. p. 43. 192 Idem, ibidem. p. 201.

193 PENHA, Eli Alves. A criação do IBGE no contexto da centralização política do Estado Novo. Memoria Institucional - 4, IBGE. Rio de Janeiro, 1993. p. 58.
} 
$(1942)^{194}$. O discurso versava sobre a necessidade de dinamizar e modernizar os aparelhos do Estado.

Até então o Brasil tinha como órgão voltado para pesquisas quantitativas a Diretoria Geral de Estatística, criada em 1871. Esse mudou algumas vezes de nome e função, mas não era suficiente para atender as demandas da nova República. Em 1936 Getúlio Vargas efetiva a criação do INE - Instituto Nacional de Estatística que já existia por decreto desde 1934. No mesmo ano, há a Convenção Nacional de Estatística que "serviu como base legal para o que Vargas chamaria de 'arcabouço dos sistemas de informação'"195. O objeto do governo federal era concentrar, racionalizar e padronizar as pesquisas e sistema de informação no país e fazer a integração socioespacial. Logo depois, em 1937, nasceu o Conselho Brasileiro de Geografia (CBG) que incorporou o INE. Assim, já na época do Estado Novo, em 1938 o Decreto-Lei n. 218 cria o IBGE, Instituto Brasileiro de Geografia e Estatística.

A criação do IBGE respondia a demanda do Estado para conhecer o território e poder planejar as políticas públicas através de estudos científicos, mas era, acima de tudo, "inspirado pelo pensamento político de unidade e progresso do país, disse Mário Augusto Teixeira de Freitas, secretário-geral do Instituto em 1943"196. Estava ligado à tentativa de entender o Brasil e formar uma imagem única ${ }^{197}$ :

No princípio era o caos! Reinavam a desordem e a confusão no quadro territorial brasileiro. Nenhuma norma racionalizadora se impunha, em meio ao tumulto, no sentido de uma razoável caracterização dos âmbitos geográficos. O Brasil não tinha, dessa maneira, a medida exata de sua grandeza física, porque Ihe faltavam os elementos indispensáveis à perfeita definição de sua imagem. Por conta do desconhecimento do quadro territorial em detalhes, os levantamentos estatísticos quase

\footnotetext{
194 Idem, ibidem. p. 48.

195 IBGE. Memória - Sínteses históricas e linha do tempo. 2014. Disponível em:

http://memoria.ibge.gov.br/sinteses-historicas/linha-do-tempo acessado em 06/01/2014.

196 RUBINSTEIN, Lícia. "O censo vai contar para você': design gráfico e propaganda política no Estado Novo". Dissertação de Mestrado. PUC Rio, Rio de janeiro, 2007. p. 80.

197 FUNDAÇÃO Getúlio Vargas. "A campanha geográfica". O Observador Econômico e financeiro. Rio de Janeiro, p 129-135. abr/jun 1940. p. 129.
} 
sempre resultavam em fracasso. A própria administração pública brasileira, nos três planos de sua constituição - federal, estadual e municipal - deparava-se com a questão de fundamental importância que era a do desconhecimento da ubiquação e condições topográficas de sua área de jurisdição.

Entre os assuntos para se entender no Brasil, a alimentação era central. Partimos da premissa de que os hábitos alimentares são fatores importantes para a formação da ideia de comunidade e que estes foram usados como parte do projeto político de centralização e consolidação da unidade, principalmente um contexto ditatorial. Jaime Rodrigues mostra em seu livro, Alimentação, vida material e privacidade, que a preocupação governamental com a alimentação vem desde o início do século XX, aumentando o mapeamento da alimentação popular no Brasil. As deficiências nutricionais eram, inclusive, uma das explicações para o atraso do país. Esse foi o argumento utilizado no I Congresso Brasileiro de Higiene em 1923 ${ }^{198}$. Na Revista Brasileira de Geografia de 1940 aparece $^{199}$ :

Num país velho e esgotado, o Recenseamento constitui motivo de melancolia nacional porque as investigações censitárias revelam apenas estacionamento, recuo, decadência. Mas num País como o Brasil, jovem e vigoroso, o Recenseamento deve constituir motivo de exaltação nacional, porque os resultados censitários traduzem progresso, movimento para a frente $e$ marcha para $o$ alto.

O projeto ganha força nos anos 30 , com o primeiro inquérito alimentar, como era chamado na época, que foi comandado por Josué de Castro em 1932. Feito em Recife, ele contou com a entrevista de 2.585 pessoas. A preocupação de Castro era mapear as lacunas e promover políticas públicas para erradicar a fome. "Mais grave ainda que a fome aguda e total, devido às

198 Rodrigues, Jaime. Op. Cit. p. 37.

199 Revista Brasileira de Geografia, n. 2 ano II, abril 1940. p. 316. 
suas repercussões sociais e econômicas, é o fenômeno da fome crônica ou parcial, que corrói silenciosamente inúmeras populações do mundo"200.

Assim, ampliam-se os inquéritos alimentares para o diagnóstico desta sociedade, principalmente da classe operária, as máquinas que trabalhavam incessantemente ${ }^{201}$.

Um dos grandes obstáculos ao planejamento de soluções adequadas ao problema da alimentação dos povos reside exatamente no pouco conhecimento que se tem do problema em conjunto, como um complexo de manifestações simultaneamente biológicas, econômicas e sociais.

Faz-se necessário, então, as pesquisas estatísticas para a compreensão do país. Um grande movimento acontece para a promoção do Recenseamento Geral de 1940, como mostra a figura 4202:

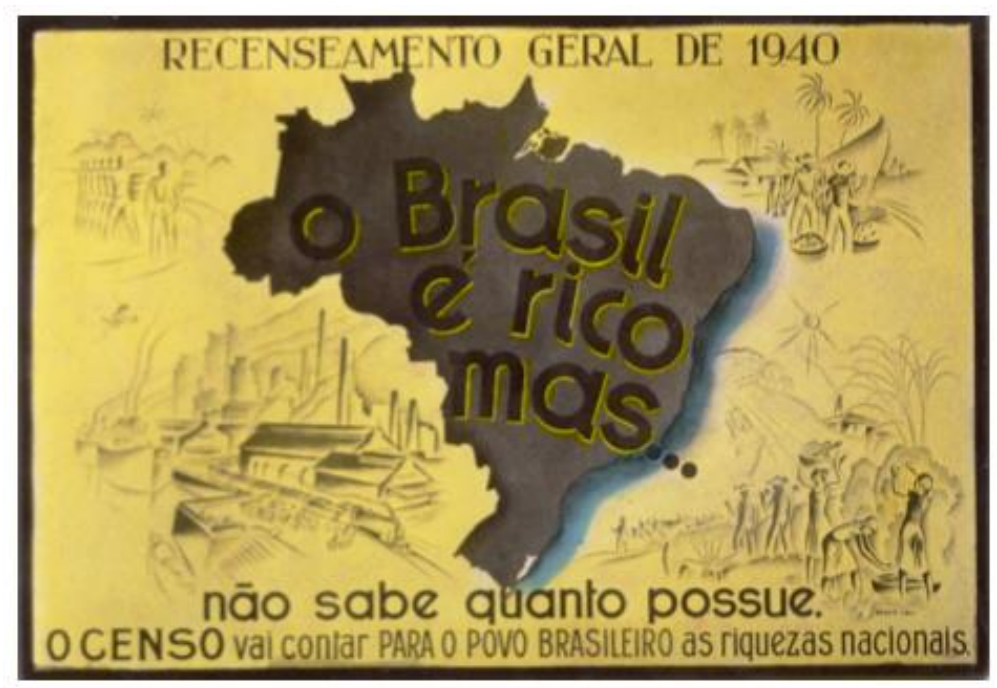

Figura 05: Peça gráfica de propaganda do Recenseamento Geral de 1940. Primeiro recenseamento feito pelo IBGE

Muitas destas pesquisas feitas entendiam que a população era ignorante em relação à alimentação e que a deficiência nutricional não era um problema de renda, e sim dá "má" escolha. No texto a Alimentação do trabalhador, de

200 CASTRO, Josué. "Fome como força social: fome e paz". In: Fome, um tema proibido. São Paulo: Civilização Brasileira, 2003. p. 83.

201 CASTRO, Josué. Geografia da Fome. Rio de Janeiro: O Cruzeiro, 1946. p. 54.

202 RUBINSTEIN, Licia. Op. Cit. 
Alexandre Moscovo, feito para o Serviço de Propaganda e Educação Sanitária do MEC em 1940, aparece 203 :

O trabalhador não usa legumes, não se utiliza de frutas, não toma leite e não come ovos, embora possa encontrá-los ao alcance, sem grande esforço, oferecidos pela uberdade do solo nacional a troco de diminuto trabalho ou mesmo sem ele pela sua espontânea fertilidade. É o lastimável contraste entre a pujança da terra e o depauperamento orgânico do homem, conduzindo ao enfraquecimento da raça, resultantes da ignorância, da falta de educação e do descaso público na orientação de uma política alimentar para a solução do problema.

Era necessário combater a "ignorância" da população que optava pelos mesmos alimentos e espalhar a ideia de uma alimentação racional "como base de políticas públicas na área"204. Tal proposta resultou em vários estudos. Como um movimento dinâmico que se retroalimenta, os inquéritos alimentares auxiliavam o entendimento do país e forneciam material para a criação do discurso e da imagem que se tornava um projeto para modificar os hábitos.

Esta relação era usada também em outros países, entre eles, a Itália. Janine Collaço, em sua tese sobre formação da identidade italiana em São Paulo, mostra como Mussolini utilizou o alimento para construir a ideia de uma só nação, culturalmente unificada. O governo fascista dedicou grandes esforços para uma campanha sobre o consumo, mais do que para a produção. Uma delas, por exemplo, tratava de promover o pão de farinha branca, criando, inclusive, a Festa do Pão ${ }^{205}$. Ora, essa campanha não poderia ser criada a partir de algo que não era familiar àquela sociedade, assim o pão, que já era consumido por boa parte da população, ganha a cena principal e passa a ser alimento fundamental.

203 RODRIGUES, Jaime. Op. Cit. p. 95.

204 Idem, ibidem. p. 105.

205 COLLAÇO, Janine Helfst Leicht. "Saberes e Memórias: cozinha italiana e construção identitária em São Paulo". Tese de doutorado, Departamento de Antropologia da Universidade de São Paulo, 2009. p. 49. 
No Brasil, a ditadura militar pós 1964 tinha como motes para a propaganda "o país do futuro" e o "milagre econômico". A grande desigualdade social era mascarada pela ideia de desenvolvimento - e este atendia a demanda da nação e proporcionava à população maior poder de consumo ${ }^{206}$.

O aprofundamento do autoritarismo coincidiu com, e foi amparado por, um surto de expansão da economia - o festejado 'milagre econômico' - que multiplicou as oportunidades de trabalho, permitiu a ascensão de amplos setores médios, lançou as bases de uma diversificada e moderna sociedade de consumo, e concentrou a renda a ponto de ampliar, em escala inédita no Brasil urbanizado, a distância entre o topo e a base da pirâmide social.

Neste contexto houve uma mudança na forma de consumo e surge a necessidade de estudar o poder de compra e hábitos dos brasileiros e para isso uma pesquisa que, a princípio, era para determinar tais dados e ajudar a formar os preços.

O IBGE já existia como sistema nacional de pesquisa, como foi mostrado, fruto do Estado Novo. Mas esse sistema ainda apresentava, segundo o governo Médici, deficiências que atrasavam os estudos ${ }^{207}$. Assim, no começo dos anos 70, o IBGE é reformulado, "passando a ser concebido como elemento de materialização e sustentação da integração entre os sistemas de pesquisa e planejamento e se apresentando como intérprete da realidade nacional" 208 . Essa tendência de centralização fez com que este órgão fosse vinculado ao Ministério do Planejamento, Orçamento e Gestão. A mudança deste cenário só virá 1985, com o retorno à democracia e a criação da Comissão de Reforma Administrativa (CRA).

\footnotetext{
${ }^{206}$ ALMEIDA, Maria Hermínia Tavares de \& WEIS, Luiz. "Carro-zero e pau-de-arara: o cotidiano da oposição de classe média ao regime militar". In: NOVAIS, Fernando (org). Historia da vida provada no Brasil - contrastes da intimidade contemporânea. Vol 04. São Paulo, Companhia das Letras, 1998. p. 333.

207 SENRA, Nelson de Castro. Uma breve história das estatísticas brasileiras (1822-2002). Rio de Janeiro: IBGE/CDDI, 2009.

208 SENRA, Nelson de Castro. História das estatísticas brasileiras, v.4: estatísticas formalizadas (1972-2002). Rio de Janeiro: IBGE, 2009.
} 
Em 1973 ocorre a nomeação das primeiras nove Regiões Metropolitanas do Brasil: São Paulo, Porto Alegre, Recife, Curitiba, Belém, Belo Horizonte, Fortaleza, Salvador e, em 1974, Rio de Janeiro. Estas são o recorte deste trabalho no que tange à análise comparativa de todas as pesquisas alimentares, já que as duas primeiras POF têm apenas essas regiões como campo. A Constituição Federal de 1988 facultaria aos estados a instituição de Regiões Metropolitanas, que no Censo 2010 já eram 36 (além de 3 Regiões Integradas de Desenvolvimento - RIDEs). Mantivemos apenas as nove iniciais.

Com o fim da ditadura e retorno da democracia, criou-se a Comissão de Reforma Administrativa (CRA) que tinha como objetivo desburocratizar e descentralizar além de informatizar o sistema. Essa operação resulta no fortalecimento de núcleos regionais, além da criação do Centro de Documentação e Disseminação de Informações, o CDDI. No final do período da pesquisa podemos considerar o IBGE como uma entidade da administração pública federal, vinculada ao Ministério do Planejamento, Orçamento e Gestão, que possui quatro diretorias e dois outros órgãos centrais. Para que suas atividades possam cobrir todo o território nacional, o IBGE possui a rede nacional de pesquisa e disseminação, composta por:

- 27 Unidades Estaduais (26 nas capitais dos estados e 1 no Distrito Federal)

- 27 Setores de Documentação e Disseminação de Informações (26 nas capitais e 1 no Distrito Federal)

- 581 Agências de Coleta de dados nos principais municípios.

\subsection{Definições metodológicas das pesquisas}

O ENDEF, a primeira grande pesquisa realizada pelo IBGE, foi ímpar, sem precedentes e não houve outra posteriormente com tamanha complexidade. Por isso, optamos por separar a apresentação dos resultados apresentados por elas. Há, em certo sentido, uma dificuldade intrínseca em 
comparar o ENDEF com as POF, mesmo que o IBGE o faça. Uma está preocupada com o consumo efetivo e outra com aquisição. Isso posto, tomamos o cuidado de diferenciar as definições e objetivos das mesmas, comparando apenas os números, que têm por base o mesmo sistema de medidas.

Além disso, temos de nos atentar para algumas variações entre as cinco pesquisas analisadas, não apenas no objeto de análise mas também no objetivo, já que perpassamos projetos governamentais bem distintos ao longo destes quase quarenta anos. Tendo isso em vista, analisamos as definições metodológicas disponíveis para consulta, a do ENDEF e as duas últimas POF, de 2002-2003 e 2008-2009. As POF intermediárias têm as definições na introdução dos resultados que são levadas em consideração.

O IBGE define como domicílio para o ENDEF 209 :

a moradia estruturalmente independente, constituída por um ou mais cômodos com entrada privativa. Por extensão, edifícios em construção, embarcações, veículos, barracas, tendas, grutas e outros locais que estiverem servindo como moradia, também serão considerados como Domicílios.

A definição para a POF de 2008 não muda muito ${ }^{210}$ :

Domicílio é a unidade amostral da pesquisa, consistindo também em importante unidade de investigação e análise para caracterização das condições de moradia das famílias. É a moradia estruturalmente separada e independente, constituída por mais cômodos, sendo que as condições de separação e independência de acesso devem ser satisfeitas.

Classificam os domicílios em dois tipos: os particulares, que servem de moradia para uma ou mais família (no máximo cinco), mesmo que este esteja localizado em um estabelecimento industrial ou comercial. Também são considerados domicílios particulares, os que estiverem servindo de moradia a

209 IBGE. Estudo Nacional de Despesa Familiar - Manual de Instruções. Rio de Janeiro, 1974. p. 10.

210 IBGE, Nota Técnica. Rio de Janeiro, 2008. p. 03. 
uma só pessoa, ou a grupos de até cinco pessoas não ligadas por laços de parentesco ou dependência doméstica. "As casas de cômodos (cabeças-deporco, cortiços, etc.) e os edifícios de apartamentos constituirão um conjunto de domicílios particulares"211. O segundo tipo, domicílios coletivos, são os "hotéis, pensões, asilos, orfanatos, recolhimentos, conventos, penitenciárias, quartéis, etc. (...) ou que sejam ocupados por um grupo de seis ou mais pessoas sem laço de parentesco ou subordinação doméstica (...)"212. Estes não foram objeto de pesquisa.

Tanto o ENDEF quanto as POF usam o termo "família" para determinar as "pessoas moradoras do domicílio, ligadas por laços de parentesco, dependência doméstica ou normas de convivência, sem referência explícita ao consumo ou despesas"213. O nome família muitas vezes é usado para determinar a Unidade de Consumo.

Apesar de o pesquisador permanecer sete dias em cada domicílio, o período de referência das informações sobre despesas e rendimentos varia conforme o objeto em questão, podendo ser de sete dias, trinta dias, noventa dias e doze meses. Por exemplo, alimentação fora de casa tem como período de referência sete dias, isso quer dizer que na semana da coleta o pesquisado irá considerar a alimentação fora de casa nesses sete dias, enquanto um aparelho de som tem o período de referência de doze meses, assim o pesquisado precisa colocar na caderneta se adquiriu algum aparelho de som nos últimos doze meses ${ }^{214}$.

O IBGE define como "Unidade de Alimentação" (UA) - "o conjunto de pessoas cujas principais refeições, ou parte delas, são preparadas ou obtidas de 'uma mesma fonte de alimentação', entendida como tal, 'um mesmo estoque de alimentos' ou ainda 'um conjunto de despesas alimentares bem definidas"'215.

\footnotetext{
211 IBGE. Estudo Nacional de Despesa Familiar - Manual de Instruções. Op. Cit. p. 11.

212 Idem, ibidem. p. 11.

213 IBGE, Notas técnicas, Op. Cit. p. 01.

214 IBGE, Manual do agente de pesquisa. Rio de Janeiro, 2002. p. 205.

215 IBGE, Estudo Nacional de Despesa Familiar - Manual de Instruções. Op. Cit. p. 17.
} 
O número de unidades de alimentação do domicílio "será estabelecido pelo número de fontes de alimentação independentes ali encontradas, isto é, unidades que tenham seus próprios estoques e despesas alimentares definidas." 216 Os componentes dessa unidade podem ser os moradores, que são os membros da família, pensionistas, empregados domésticos, agregados, conviventes e os não moradores que são os hóspedes, empregados diaristas, pensionistas diaristas e convidados. Essa UA que é o centro da pesquisa, sendo o questionário preenchido a partir de cada uma delas. Entendemos por UA por exemplo, uma cozinha.

O comensal é a pessoa que participa de pelo menos uma das principais refeições da Unidade de Alimentação ${ }^{217}$. As principais refeições são o café da manhã, o almoço, o lanche e jantar. É considerada extra toda a alimentação consumida nos intervalos das principais refeições ou após o jantar ${ }^{218}$. Se o comensal leva a refeição preparada em casa para comer em outro local, como a marmita para o trabalho por exemplo, essa refeição entra na pesquisa, assim como refeição comprada para o consumo em casa ${ }^{219}$. Refeições em restaurantes e locais semelhantes, inclusive no trabalho, também foram registradas ${ }^{220}$. Porém não são contabilizados os alimentos consumidos nestas últimas, servindo apenas para medição do orçamento gasto e não influencia na quantidade de cada produto. Dessa forma, enumera-se os alimentos consumidos na casa e nas refeições fora de casa coloca-se "Restaurante" e o valor gasto ${ }^{221}$. Se ela fez refeição em outra casa, como visita, ela é considerada, mas não seu peso.

No caso do ENDEF as sobras e desperdícios também são contabilizados, como as sobras na panela, alimento dado ao animal ou jogado fora. São registradas todas as compras da semana e onde foram feitas, como supermercados, feiras, armazéns, vendedores ambulantes e estabelecimentos especializados $^{222}$. Caso não tenham sido compradas elas são registradas como

\footnotetext{
216 Idem, ibidem. p. 18.

217 Idem, ibidem. p. 17.

218 Idem, ibidem. p 45.

219 Idem, ibidem. p 46.

220 Idem, ibidem. p 55.

221 Idem, ibidem. p 57.

222 Idem, ibidem. p 54.
} 
auto-consumo, oriundas de pesca, caça, colheita, apanha ou criação e cultivo próprio; troca, se foram obtidos por intercâmbio de alimentos; doação, recebidos gratuitamente de outra pessoa ou entidade; retirado do negócio ou recebimento de bens, se foram retirados do estoque de casa de comércio, serviço ou indústria de propriedade do membro da UA ou se foram recebidos como pagamento 223 .

O IBGE difere alimento de ingrediente da seguinte forma: alimento são os principais componentes da refeição, como batata, feijão, carne, etc. Ingrediente está exemplificado como sal, açúcar, pimenta, o que chamamos de tempero ${ }^{224}$.

Também registra as preparações dos alimentos: "cabe destacar que a forma de preparo pode alterar a composição nutricional dos alimentos e, sendo assim, o relato da forma de preparação era prioritária para a seleção dos itens no cadastro dos alimentos, principalmente para as carnes e legumes"225.

Selecionaram 15 opções de preparos culinários, sendo também possível "não se aplica":

$$
\begin{aligned}
& 1 \text { - Cru(a) } \\
& 2 \text { - Cozido(a) } \\
& 3 \text { - Grelhado(a)/Brasa/Churrasco } \\
& 4 \text { - Assado(a) } \\
& 5 \text { - Frito(a) } \\
& 6 \text { - Empanado(a)/À milanesa } \\
& 7 \text { - Refogado(a) } \\
& 8 \text { - Molho vermelho } \\
& 9 \text { - Molho branco } \\
& 10 \text { - Ao alho e óleo }
\end{aligned}
$$

\footnotetext{
223 Idem, ibidem. p 62.

224 Idem, ibidem. p 60.

225 IBGE, Nota técnica, Op. Cit. p. 18.
} 
11 - Com manteiga/Óleo

12 - Ao vinagrete

13 - Ensopado

14 - Mingau

$15-$ Sopa $^{226}$

Essas categorias não contemplam integralmente as preparações culinárias, além de não sabermos se todas as pesquisas utilizam dessas, já que duas não têm o material metodológico completo disponível para consulta. Mas em todas as pesquisas os métodos aos quais os alimentos são submetidos são levados em consideração.

O IBGE define consumo alimentar como 227 :

os alimentos que entram na UA durante o período da pesquisa, mais o estoque no primeiro dia, menos o estoque final. $\mathrm{Na}$ prática, o consumo corresponde aos alimentos efetivamente pesados no momento da preparação das refeições, mais diversos extras consumidos entre as refeições.

No que se refere as definições da pesquisa, o que o IBGE entende por unidade de alimentação ou domicílio por exemplo, não varia muito entre elas. Mas temos no eixo central uma distinção essencial. A primeira, o ENDEF, baseada na metodologia da FAO, que estava preocupada com o consumo alimentar e a comparação com as necessidades nutricionais, o que de fato elas consumiam e não apenas o que adquiriam. Já as POF focaram suas pesquisas na aquisição alimentar, isso quer dizer que o foco era os alimentos adquiridos, de forma monetária ou não, mas não o que efetivamente era consumido. Essa diferença pode ser traduzida em duas formas distintas de coleta de dados: enquanto o ENDEF acompanhava as refeições, pesando os alimentos consumidos e as sobras, as outras pesquisas anotavam os alimentos adquiridos e esses dois dados não necessariamente representam a mesma

\footnotetext{
226 Idem, ibidem. p. 18.

227 IBGE. Estudo Nacional de Despesa Familiar - Manual de Instruções. Rio de Janeiro, 1974. p 14.
} 
coisa. A constatação dessa diferença deu-se durante a análise dos dados, mesmo assim optamos em manter o ENDEF já que os resultados são ainda mais precisos do que as pesquisas subsequentes.

O período de coleta de dados da POF assim como o ENDEF é de doze meses, com cada domicílio recebendo visita durante sete dias, menos na POF de 1987-1988, que foi de quatorze dias ${ }^{228}$. Alguns estudos colocam que o tempo de visita é de nove dias, porque consideram os dois dias de abordagem do pesquisador que não há computação de dados.

Para a coleta de dados são respondidos seis questionários:

POF1 - característica do domicílio e dos moradores, em que analisa como é o domicílio alvo da pesquisa, material da habitação, tamanho, cômodos, água e esgoto encanados etc. Além do número de moradores, grau de parentesco e formação da unidade de consumo. Altura, peso e data de nascimento.

POF2 - questionário de aquisição coletiva, que serve para pesquisar produtos que, em geral, são de uso de todos os moradores daquele domicílio e que não são adquiridos com frequência, como eletrodomésticos, reformas, serviços de energia elétrica e gás.

POF3 - caderneta de aquisição coletiva que é usada para registrar a aquisição de alimentos e bebidas, artigos de higiene pessoal e de limpeza. Para cada Unidade de Consumo haverá uma caderneta e, no tema que nos interessa nessa pesquisa, este é o principal documento. O preenchimento deste deve ser feito pelo dono da casa e entende-se como tal aquele que, independentemente do sexo, controla as despesas do orçamento doméstico. Ele é composto por um questionário estruturado em oito quadros, além de instruções para o preenchimento, com exemplos e descrição do produto; guia de registro de aquisições, para recordar do tipo de aquisições que precisam ser registradas e a folha suplementar, para complementar o registro das aquisições caso o espaço do quadro não seja suficiente. Deverão ser registradas nessa caderneta as aquisições efetuadas no período de sete dias, mesmo que os produtos não tenham sido consumidos durante este período ou que tenham

228 IBGE. Pesquisa de Orçamentos Familiares. Rio de Janeiro, 1991. P 12 
sido adquiridos para consumo de não moradores deste domicílio. O informante preenche a caderneta com os seguintes dados:

- dia da semana

- data

- descrição detalhada do produto

○ quantidade

- unidade de medida (descrição completa)

- tipo de produto (descrição completa)

- valor e local de aquisição

A forma de aquisição que também é um item desta caderneta e é preenchida pelo agente de pesquisa. Podem ser:

01 - Monetária à vista para a Unidade de Consumo

02 - Monetária à vista para outra Unidade de Consumo

03 - Monetária a prazo para a Unidade de Consumo

04 - Monetária a prazo para outra Unidade de Consumo

05 - Cartão de crédito à vista para a Unidade de Consumo

06 - Cartão de crédito à vista para outra Unidade de Consumo

07 - Doação

08 - Retirada de negócio

09 - Troca

10 - Produção própria

11 - Outra

São preenchidos os valores, local de aquisição, como supermercado, feira, açougue ou farmácia.

POF 4 - questionário de aquisição individual que registra as aquisições de cada membro do domicílio que não foram contempladas nas POF 2 e POF 3.

POF 5 - questionário de trabalho e rendimento individual que deverá ser preenchida por cada unidade de orçamento-trabalho e/ou rendimento que se encontra na unidade de consumo do domicílio. 
POF 6 - Avaliação das condições de vida. Questionário subjetivo que cada Unidade de Consumo preenche para o visualizar o entendimento do entrevistado sobre as condições de vida de sua família. ${ }^{229}$

\subsection{ENDEF - Estudo Nacional da Despesa Familiar}

Para atender a demanda governamental na década de 70 que queria entender o consumo no país e assim projetar estratégias econômicas, Isaac Kerstenetzky, então presidente da Fundação IBGE, pretendia a construção de um índice nacional de preços. Um grupo de trabalho foi criado para essa tarefa, que não poderia ser cumprida sem a pesquisa de orçamento familiar. $\mathrm{Na}$ procura de uma metodologia que respondesse a este pedido, fizeram um acordo com a Organização das Nações Unidas para Alimentação e Agricultura (FAO) e adotaram uma linha de pesquisa francesa que estava preocupada com a diferença entre orçamento e capacidade de escolha nutricional ${ }^{230}$. Nascia 0 Estudo Nacional da Despesa Familiar, o ENDEF, comandada por Luiz Affonso Parga Nina e que se tornou a primeira grande pesquisa sobre o consumo alimentar doméstico feita de forma centralizada e nacional.

Sua formulação, diferentes das pesquisas similares que sucederam-na, está pautada no debate sobre segurança alimentar e seria dada aqui maior atenção ao consumo, e não apenas à aquisição. "Pretendia-se, com isso, obter elementos para estudos sobre condições de nutrição"231. No jornal Folha de São Paulo de 21 de agosto de 1974 foi publicada reportagem com o título: "O Brasil vai saber quem come bem e quem come mal". Queriam compreender a forma de se alimentar no país do "milagre econômico"232:

\footnotetext{
229 IBGE. Pesquisa de Orçamentos Familiares 2008-2009. Manual do Agente de Pesquisa. Rio de Janeiro, 2008.

230 MALAVOTA, Leandro; SANTANA, Luciana e MONTEIRO, Pedro. "Um retrato que o Brasil desconhece: a documentação do ENDEF como fonte de informações para o historiador" XVII Simpósio Nacional de História. Natal, 2013.

${ }^{231}$ Estudo Nacional de Despesa Familiar - Dados Preliminares. Rio de Janeiro, 1977. p. 11.

232 Idem, ibidem. p. 11.
} 
a busca de informações diversificadas, em setores não suficientemente cobertos pelos sistemas convencionais, interessando a áreas de estudos sociais e econômicos, Procura-se, assim, atender principalmente às necessidades de planejamento tanto governamental como privado, compondo uma visão geral que congrega aspectos distintos da situação nacional, pouco conhecidos alguns e desconhecidos outros.

O início do trabalho de campo foi em 19 de agosto de 1974, terminando em 11 de agosto de 1975. Cada agente visitava dois domicílios escolhidos durante uma semana, sete dias consecutivos, duas ou três vezes ao dia. Eles anotavam os produtos consumidos em um questionário padrão composto por vinte e cinco campos e a quantidade correspondente que era contabilizado em quilograma por pessoa. Para isso, acompanhavam as refeições, pesando cada uma, inclusive as sobras que eram contabilizadas novamente ${ }^{233}$. Para a amostra, foram escolhidos mais de 55 mil domicílios com o total de 53.311 famílias em âmbito nacional.

Também eram feitos comentários sobre inúmeros aspectos. Ao final do questionário fechado havia um item, "Observações sobre a unidade pesquisada", no qual o agente poderia colocar suas impressões que não foram contempladas pelas opções anteriores. Esse espaço era uma novidade nas pesquisas estatísticas no país e enfrentou dificuldades para ser levada em consideração, não ganhando uma análise de fôlego até hoje. $O$ registro era para a criação de um banco de dados não estruturados que iriam ser cruzados com os dados quantitativos ${ }^{234}$.

"Aos hábitos alimentares era dispensada atenção especial, registrandose informações sobre o cardápio da família durante o período observado e os custos da alimentação." ${ }^{235}$. Outros elementos eram ponto de atenção da

\footnotetext{
233 IBGE. Estudo Nacional de Despesa Familiar - Manual de Instruções. Op. Cit. ${ }^{234}$ MALAVOTA, Leandro; SANTANA, Luciana e MONTEIRO, Pedro. "Um retrato que o Brasil desconhece: a documentação do ENDEF como fonte de informações para o historiador" XVII Simpósio Nacional de História. Natal, 2013.

235 Idem, ibidem.
} 
pesquisa, como vestuário, moradia, aquisição de bens, medicamentos e trocas não monetárias. Infelizmente, esses arquivos não são disponibilizados para consulta pelo IBGE.

Dois fatores tornam essa pesquisa ímpar no que tange as outras feitas pelo instituto: a associação entre elementos qualitativos e quantitativos, já que combinavam os dados estruturados das questões fechadas com observações abertas feitas pelo agente, e a preocupação com o que de fato era consumido e não apenas o que era adquirido. Neste trabalho focaram também em definir o "ritmo alimentar". A partir das quatro refeições diárias, café da manhã, almoço, lanche e jantar, faz-se as combinações possíveis das várias formas do peso dessas refeições na alimentação. Ao todo surgiram quinze ritmos diferentes. Para o ritmo café-almoço-jantar, por exemplo, o estudo estimou os pesos 0,18; 0,49 e 0,33 . Isso quer dizer que o café da manhã representa $18 \%$ das calorias ingeridas no dia, assim como o almoço $49 \%$ e o jantar $33 \% 236$.

Apesar na complexidade no recolhimento dos dados, estes não foram analisados a ponto de apresentarem resultados sobre o consumo como poderia ser feito. A pesquisa preliminar de 1977 do IBGE parece não ter ganhado notoriedade da população. Alguns estudos pontuais surgiram tempos depois, como Os principais tipos alimentares do Brasil de Mauricio Pereira Leite Vasconcellos, publicado em 1987 pela FAO e muito mais completo. Uma pesquisa pioneira no método e na abrangência, em um período no qual ela era muito necessária, não teve seus resultados divulgados em sua totalidade. $A$ partir de estudos posteriores podemos hoje concluir alguns elementos.

O ENDEF identificou 1428 variedades de alimentos consumidos no país e 235 preparações culinárias, resultando em 3522 códigos para identificar as várias formas (com ou sem casca, se foi cozido ou frito, etc.). A preocupação da publicação de Vasconcellos, obra na qual nos baseamos, é entender as principais fontes de calorias no país. Selecionou-se todos os alimentos que representem mais de $1 \%$ dos ganhos calóricos e os trinta principais, objetos de pesquisa, representam $80,97 \%$ das calorias consumidas no âmbito nacional.

${ }^{236}$ IBGE. Estudo Nacional de Despesa Familiar - Dados Preliminares. Op. Cit. p. 14. 
O ENDEF separou as regiões da seguinte forma:

Região 1 - Rio de Janeiro;

Região 2 - São Paulo;

Região 3 - Paraná, Santa Catarina e Rio Grande do Sul;

Região 4 - Minas Gerais e Espírito Santo;

Região 5 - Maranhão, Piaui, Ceará, Rio Grande do Norte, Paraíba, Pernambuco, Alagoas, Sergipe e Bahia;

Região 6 - Distrito Federal (Brasília); e,

Região 7 Rondônia, Acre, Amazonas, Roraima, Pará, Amapá, Mato Grosso do Sul, Mato Grosso e Goiás.

Mato Grosso do Sul, Mato Grosso e Goiás constituem uma subdivisão da região 7 muitas vezes chamada de região 8 ou 7-B237.

Algumas conclusões apontadas por Vasconcellos nos mostra o perfil alimentar da época. $O$ arroz polido é o alimento de maior aporte calórico ( $15.87 \%$ das calorias consumidas no país) e tem na região cinco (nordeste) seu mais baixo nível de importância. Segundo ele, essa discrepância se dava pelo consumo do arroz pilado ou integral. Ora, se olharmos a tabela, o percentual do arroz integral é de 5,94\% enquanto arroz polido é de 6,43\%. Encontramos a grande diferença e um dos possíveis motivos para o baixo consumo de arroz polido no consumo de farinha de mandioca, que representa $21,91 \%$ das calorias ingeridas, enquanto em outras regiões, como a do Rio de Janeiro, representa apenas $2,48 \%$. Percebemos a farinha de mandioca como de fundamental importância no nordeste. Ela também aparece na região sete, que engloba os atuais norte e centro-oeste como o segundo produto $(11,84 \%)$. Vale destacar que o arroz polido é detentor de $22,74 \%$ em São Paulo e $22,76 \%$ no Distrito Federal ${ }^{238}$.

O milho em grão só tem importância no Nordeste e a farinha de trigo é importante na região 3 (Sul), chegando a 10,14\%, enquanto nas outras regiões não chega a 1\%. Quanto maior a urbanização, maior o consumo de farinha de

\footnotetext{
237 IBGE. Estudo Nacional de Despesa Familiar - Dados Preliminares. Op Cit. p. 12. 238 VASCONCELLOS, Maurício Teixeira Leite de. Os principais tipos alimentares do Brasil. Divisão de Políticas Alimentares e de Nutrição, FAO, 1987. p. 04.
} 
trigo e produtos industrializados. O pão francês aparece protagonista para todas as regiões, chegando a $7,74 \%$ no Rio de Janeiro e uma média nacional de $5,21 \%$.

Em reportagem da Revista Veja de 16 de março de 1977, que comenta os resultados parciais da pesquisa, o leite aparece como o alimento mais consumido na área metropolitana, seguido do arroz e açúcar. E dizº:

a palavra 'fome' seria constantemente citada nos relatórios das equipes de campo. Em São Paulo, por exemplo, seria encontrada uma família que não comeu absolutamente nada durante os três primeiros dias da pesquisa (...). No Rio de Janeiro, não foram poucas as constatações de famílias que enganavam a fome com grandes quantidades de água açucarada.

Realmente, o açúcar aparece como o segundo produto em importância calórica em todas as regiões (exceto a sete, onde é o terceiro) e tem a média nacional de $11,89 \% 241$.

Os feijões refletem as preferências regionais pelos tipos localmente consumidos. Enquanto o feijão-preto representa no Rio de Janeiro 6,89\%, em São Paulo esse número cai para $0,19 \%$. O mulatinho e o de corda são muito consumidos no nordeste $(4,51 \%$ e $7,37 \%$ respectivamente) e em São Paulo aparece o consumo do roxo, com $2,01 \%$, e do rosinha $(2,20 \%)^{242}$.

O óleo de soja é importante na maioria das regiões, apresentando uma média nacional de 3,96\% sendo que São Paulo detém 7,39\%. A exceção ocorre no Nordeste, onde o consumo médio de óleos vegetais é muito baixo, menos de 1\%. A banha de porco é importante nas regiões 3,4 e 7 , o que explica a leve queda do óleo de soja nestas. Esse estudo mostra como a banha de porco está nos meios rurais enquanto nas cidades se usa óleos vegetais ${ }^{243}$.

\footnotetext{
239 Idem, ibidem. p. 04.

240 "A FOME na mesa”. Revista Veja. Edição 445, 16 de março de 1977. p. 81.

241 VASCONCELLOS, Maurício Teixeira Leite de. Op. Cit. p. 06.

242 Idem, ibidem. p. 06.

243 Idem, ibidem. p. 04.
} 
No âmbito alimentar, além da introdução de novos equipamentos, neste período intensificou-se o crescimento da venda dos produtos industrializados e mudança da forma de aquisição de outros itens, aqueles que não são processados, como o feijão e o arroz. Antes vendidos por peso direto dos toneis, passa a ser disponível nas gôndolas dos supermercados. Os produtos enlatados ganharam espaço, como as ervilhas e milhos, legumes picados ou o leite condensado. "Os avanços produtivos acompanharam-se de mudanças significativas no sistema de comercialização. As duas grandes novidades foram certamente o supermercado e o shopping center."244 O primeiro supermercado é O Disco, no Rio de Janeiro, do poeta Augusto Frederico Schmidt e o shopping center é o Iguatemi, em São Paulo, inaugurado em $1966^{245}$.

Vasconcellos também fala da incidência dos alimentos mais significativos na dieta familiar para criar grupos alimentares no Brasil, formando 26 tipos. O tipo 1, por exemplo, é formado pelo grupo que se alimenta principalmente de pão de trigo, mandioca, feijões, arroz e carne, sendo característico das regiões urbanas, principalmente no nordeste. Já o tipo 2, formado pelo consumo predominante de mandioca e feijões, é muito frequente nas zonas rurais no nordeste. Para ele, o tipo mais completo seria o 19, composto principalmente por arroz, pão de trigo, óleo de soja, carne e leite. Este seria o retrato das famílias ricas do país concentradas principalmente nas regiões urbanas do sudeste e sul e representando $11,3 \%$ das famílias pesquisadas $^{246}$.

Com exceção do açúcar, que aparece em todos os grupos, os alimentos que mais são citados -arroz polido e os feijões- estão em vinte e três grupos. Logo depois vem o pão e a farinha de mandioca ${ }^{247}$. A pesquisa encontrou uma grande diversidade alimentar, tanto de alimento, quanto do preparo e uma enorme discrepância de consumo entre as famílias. Mas isso não servia ao projeto nacional. Esta era uma preocupação nutricional. O que conclui a pesquisa, por fim, é que a insuficiência nutricional e calórica não passava pela

244 MELLO, João Manuel Cardoso de \& NOVAIS, Fernando. "Capitalismo tardio e sociabilidade moderna". In: NOVAIS, Fernando (org.), História da vida privada no Brasil - contrastes da intimidade contemporânea. Vol 04. São Paulo: Companhia das Letras, 1998. p. 567.

245 Idem, ibidem p. 566.

246 VASCONCELLOS, Maurício Teixeira Leite de. Op. Cit. p. 54.

247 Idem, ibidem. p. 58. 
ignorância alimentar, passava sim, pela renda. Reportagem do jornal Folha de São Paulo relata um estudo feito com dados do ENDEF em que $62,7 \%$ das famílias tinham deficiência calórica na alimentação e, coincidentemente, o número das famílias no país com renda mensal de até dois salários mínimos era de $62,4 \%{ }^{248}$. E mais do que isso, $40 \%$ estavam em uma situação de "penúria alimentar" e apenas $9 \%$ tinha uma alimentação adequada. Assim, o entendimento foi que o problema da fome no país estava ligado à distribuição de renda e não à informação nutricional como algumas campanhas defendiam.

Esses dados não foram levados à população na época. Por que a pesquisa não foi explorada e divulgada? A fome não interessava à propaganda política. A miséria, em pleno "milagre econômico", não agradava aos militares. As análises, principalmente qualitativas, tiveram a divulgação proibida porque alguns registros eram alarmantes: eram boias-frias comendo folhas do cafezal, famílias que ingeriam apenas casca de batata cozida, lixo, ratos, carvão, sabão, miolo de xaxim, lavagem de porco e minhocas. "Uma pesquisadora ficou estarrecida quando viu duas crianças brigando pelas suas fezes" no estado do Rio de Janeiro ${ }^{249}$. Assim, a fome tornou-se um tabu neste período e a pesquisa somente chegou ao público onze anos mais tarde, com apenas algumas menções na imprensa antes disso.

Para a campanha do governo ditatorial seria importante, assim como fez Mussolini, falar de um país que come feijão e arroz, coeso e desenvolvido. Olhando para a análise de Vasconcellos, não deixaria de ser respaldado nos números, já que em quase todos os tipos alimentares eles são citados. Porém, mais factível, era falar da nação com fome e açúcar em seu cardápio. E no Brasil do "milagre econômico" esses dados não tinham espaço. "(...) A inclusão ou a exclusão de quesitos, a maneira de formulá-los e o significado que lhes é atribuído são, em certa medida, reveladores das preocupações e dilemas que

\footnotetext{
248 "BAIXA renda é a maior causa da desnutrição". Folha de São Paulo. Primeiro caderno. 30 de novembro de 1981. p. 08.

249 LESSA, R. "Retrato proibido da fome". Revista Isto É. São Paulo: Gazeta Mercantil S.A., ano 9, n. $458,02 / 10 / 85$, p 30-34.
} 
marcam o pensamento social de uma época (..."250.

Esse milagre econômico foi sentido apenas nas classes médias e altas com a introdução de novos equipamentos no âmbito doméstico. Passamos a fabricar muitos produtos no país, e estes foram introduzidos nos domicílios, modificando os hábitos domésticos. "A indústria do alumínio era uma realidade, a do cimento, a do vidro e a do papel cresceram e se modernizaram; as indústrias tradicionais, de alimentos, a têxtil, de confecções, calçados, bebidas e móveis também"251. As indústrias farmacêutica e de cosméticos se desenvolveram e agora produzíamos carros para correrem nas novas estradas que cortavam o país. Dentro de casa havia ferro elétrico e panela de pressão, fogão a gás e frigideiras de alumínio, liquidificador e batedeira.

Se por um lado hoje temos acesso a muitos dados do ENDEF que nos fornecem uma medida importante de como se alimentavam as famílias brasileiras na década de 70 , por outro vemos na política ditatorial o receio de assumir que o milagre era para poucos. "Esquecer, ou ao mesmo interpretar mal a história, é um fator essencial na formação de uma nação" já disse há muito tempo Ernest Renan ${ }^{252}$.

\subsection{POF - Pesquisa de Orçamentos Familiares}

Se o clima na década de 70 era do milagre econômico, a "sensação dos brasileiros era de que faltavam uns poucos passos para finalmente nos tornarmos uma nação moderna"253. Em 80 essa sensação se inverte, e a visão sobre a modernidade brasileira ganha feições pessimistas. Conhecida como a década perdida, ela ficou marcada pela estagnação econômica, da produção industrial e aceleração da inflação.

\footnotetext{
250 OLIVEIRA, Jane Souto, "Brasil mostra a tua cara": imagens da população brasileira nos censos demográficos de 1872 a 2000. Escola Nacional de Ciências Estatísticas, texto para discussão 06. Rio de Janeiro, 2003.

251 MELLO, João Manuel Cardoso de \& NOVAIS, Fernando. Op. Cit. p. 563.

252 RENAN, Ernest (1991) 'What is a Nation?', (aula dada em Paris, 1882).

253 MELLO, João Manuel Cardoso de \& NOVAIS, Fernando Op. Cit. p. 560.
} 
Assim, com o final da ditadura e o início da abertura política surge a necessidade de uma grande pesquisa que mantém como objetivo primeiro a formação do índice de preços, especificamente dois - o Índice Nacional de Preços ao Consumidor (INPC) e o Índice Nacional de Preços ao Consumidor Amplo (IPCA), além de entender a estrutura do gasto familiar e o índice do custo de vida. Nascem as Pesquisas de Orçamentos Familiares (POF). Porém adotando uma forma muito mais simples de execução, que se traduz na redução da área geográfica coberta e na forma de captação de dados, trazendo um custo menor para execução. Além disso, não são levados em conta os aspectos nutricionais ou o efetivo consumo do alimento, e sim a aquisição e o gasto com alimentos. Durante o período foram efetuadas quatro pesquisas: 1987/1988, 1995/1996, 2002/2003 e 2008/2009.

A primeira e a segunda POF, de 1987/1988 e 1995/1996, circularam sua área de ação nas regiões metropolitanas oficiais que foram definidas pelo IBGE em 1973 como colocado acima: Belém, Fortaleza, Recife, Salvador, Belo Horizonte, Rio de Janeiro, São Paulo, Curitiba, e Porto Alegre além da cidade de Goiana e o Distrito-Federal. Aqui, nestas pesquisas, não foram consideradas as aquisições não-monetárias de alimentos, como troca ou plantio.

As duas pesquisas, a de 1987/1988 e 1995/1996, foram feitas em períodos complicados em termos de preço. Por isso, entender o consumo foi o objetivo maior da empreitada. $\mathrm{Na}$ introdução da divulgação dos resultados da primeira POF aparece: "O objetivo de mensurar-se o consumo alimentar teve origem na necessidade de explicarem-se as alterações observadas na participação dos diferentes produtos no orçamento da família." ${ }^{254}$ Essa aconteceu logo após o Plano Cruzado (1986) e muitas outras tentativas de estabilização econômica (Plano Bresser, Verão, Funaro, entre outros) e a segunda logo após a implantação do Plano Real e o ajuste de preços ${ }^{255}$.

\footnotetext{
254 IBGE, Pesquisa de Orçamento Familiar 1987/1988. Rio de Janeiro, 1991. p. 9.

255 DINIZ, Bernardo Palhares Campolina; SILVEIRA, Fernando Gaiger; BERTASSO, Beatriz Freire; MAGALHÃES, Luis Carlos G; SERVO, Luciana Mendes Santos. "As pesquisas de orçamento familiar brasileiras". In: Fernando Gaiger da Silveira; Luciana Mendes Santos Servo; Tatiane Menezes; Sérgio Franciso Piola. (Org.). Gasto e consumo das famílias brasileiras contemporâneas. Brasília: IPEA, 2007, 17-57. p. 20.
} 
A partir de 2002/2003, a POF passou a ter uma abrangência nacional, além de começar a incluir dados antropométricos e itens adquiridos de forma não-monetária pela população. Com a inclusão desses itens, passamos a ter uma medida mais real do efetivo consumo da população.

Se por um lado as duas últimas POF trazem uma área de abrangência maior, elas diminuem as amostras das regiões metropolitanas. A de 1987/1988 tem uma cobertura de 13.707 unidades de consumo (13.611 domicílios) e a de 1995/1996 de 16.060 (16.043 domicílios) enquanto a de 2002/2003 esse número passa para 7.245 unidades de consumo (7.221 domicílios). Não temos o número exato para 2008/2009, porém sabemos que "a amostra da POF 2008/2009 manteve características do desenho aplicado à POF 2002/2003, mas teve sua concepção segundo o conceito de amostra mestra, que o IBGE propõe adotar para todas as pesquisas domiciliares por amostra."256

As POF mantêm o recorte anual, sendo que:

- 1987/1988 - março de 1987 a fevereiro de 1988, considerando os valores monetários de 15 de outubro de 1987;

- 1995/1996 - outubro de 1995 a setembro de 1996, considerando os valores monetários de 15 de setembro de 1996;

- 2002/2003 - julho de 2002 a junho de 2003, considerando os valores monetários de 15 de janeiro de 2003;

- 2008/2009 - 19 de maio de 2008 a 18 de maio de 2009, considerando os valores monetários de 15 de janeiro de 2009.

O ENDEF, como mostramos anteriormente, foi produzido durante a fase rígida do regime ditatorial, no discurso do milagre econômico e imensa desigualdade social. Já a segunda pesquisa, a primeira POF de 1987/1988, foi produzida em um período de alta inflação em que muitos planos tentaram contê-la (Cruzado, Bresser etc). "A POF de 1987/1988, na verdade, foi a campo durante um ano e meio, sendo o primeiro terço desconsiderado pelas

256 IBGE. Pesquisa de Orçamentos Familiares, 2008/2009. Rio de Janeiro, 2010. p. 12. 
mudanças abruptas no comportamento dos preços ocorridos com o Plano Cruzado."257 De fato, o jornal Folha de São Paulo de 10 de fevereiro de 1988 escreve: "O IBGE pretendia concluir esse estudo no início de 1987, mas chegou à conclusão que o Plano Cruzado criou em 1986 um comportamento atíico de consumo" ${ }^{258}$. A matéria coloca ainda que a pesquisa estava com quinze meses de atraso.

Os resultados dessa pesquisa foram publicados, segundo a Folha de São Paulo, em maio de 1989. E fala sobre sua importância para entender a mudança de comportamento do consumidor ${ }^{259}$ :

Ao contrário da pesquisa atualmente em vigor, feita em 1974, a nova POF reduzirá o impacto do gasto com banha de porco no orçamento familiar - responsável pela elevação da inflação de março medida pelo IBGE - e incluirá produtos como videocassete e computador doméstico, que antes não faziam parte dos hábitos de consumo do brasileiro médio.

Não foi a POF que reduziu o impacto do gasto com banha de porco no orçamento familiar e sim ela constatou que este produto já não tinha tanto espaço nas casas brasileiras. Da mesma forma, com a cultura de massa invadindo os domicílios e se instalando no Brasil, o instituto inclui novos itens oriundos da modernidade. $O$ leite de vaca pasteurizado aqui atinge seu auge, com o consumo de $62,4 \mathrm{~kg}$ anuais por pessoa. Se somarmos o consumo de açúcar refinado e cristal chegamos a cifra de mais de $22 \mathrm{~kg}$ por pessoa em um ano, número maior do que o ENDEF que já mostrava o açúcar como um dos principais fornecedores de calorias para as famílias brasileiras. Há o aumento de consumo de itens como iogurte, refrigerante e óleo de soja, enquanto cai o consumo de arroz e feijão ${ }^{260}$.

A farinha de trigo teve um crescimento estrondoso, passando de $1,833 \mathrm{~kg}$ para $4,085 \mathrm{~kg}$, também sua maior marca. Isso porque a partir do final da década

\footnotetext{
257 DINIZ, Bernardo P. Camponila et. al. Op. Cit. p. 46.

258 "IBGE vai manter cálculo do IPC criado em 1974". Folha de São Paulo, Economia A25.

259 "Cálculo do IPC da Getúlio Vargas inclui novos hábitos do consumidor", Folha de São Paulo, 30 de março de 1989, Economia, B4.

260 IBGE. Pesquisa de Orçamentos Familiares 1987/1988. Op. Cit.
} 
de 70 , houve uma produção recorde de trigo, conquistada por políticas governamentais para o incentivo do cultivo de trigo no Brasil, de remuneração diferenciada ao produtor e incentivo ao uso de tecnologia. Essas ações passaram também pelo incentivo ao consumo. O trigo era comprado do produtor pelo Estado, que repassava ao moinho, medindo seu desempenho e analisando os índices nas diferentes regiões do Brasil ${ }^{261}$. Essa postura acabou no final dos anos 80 , sendo sentida no consumo da próxima POF, com uma queda para $3,102 \mathrm{~kg}$.

A segunda POF, feita em 1995/1996 veio após o Plano Real, estabilizando os preços que vinham de um período de grande inflação e da mesma forma fez com os salários. Esse novo quadro permite um planejamento maior tanto das famílias, quanto do governo, e acompanhado da abertura comercial, muda o padrão de consumo. Um dos indicadores desse fenômeno foi aumento da demanda por bens duráveis. Os resultados da pesquisa aparecem na Folha de São Paulo: "Brasileiro consome mais carne e cerveja" ${ }^{262}$. Comparando com a POF anterior, o consumo de proteínas animais cresceu sendo o de carne bovina $9,96 \%$ e o frango $21,3 \%$. A cerveja também teve seu espaço ampliado no âmbito doméstico e seu consumo quase duplicou, principalmente nas classes de menor renda. O mesmo aconteceu com o refrigerante e o consumo de bolacha, este aumentou $24,47 \%$. A POF não deixa de apontar, porém, a discrepância entre a mesa dos pobres e a dos ricos. Nas casas com renda até dois salários mínimos, o consumo per capita anual de carne -embora tenha aumentado $4,41 \%$ - ainda é de $11,690 \mathrm{~kg}$, isso representa menos de $1 \mathrm{~kg}$ por mês. Nos domicílios com renda superior a 30 mínimos ( $R$ \$ 3.900), o consumo per capita de carne bovina é 2,3 vezes maior: $27,244 \mathrm{~kg}$ anuais ${ }^{263}$.

De acordo com a POF, o cotidiano agitado das regiões metropolitanas brasileiras tem consequências na dieta: 0 consumo de alimentos preparados (prontos ou semiprontos)

\footnotetext{
${ }^{261}$ COLLE, Célio Alberto. "A cadeia produtiva do trigo no Brasil: contribuição para a geração de emprego e renda". Dissertação de Mestrado, UFRGS, 1998.

262 ESCÓSSIA, Fernanda da. "Brasileiro consome mais carne e cerveja" Folha de São Paulo.

Dinheiro, 4 de dezembro de 1998. p. 12.

263 Idem, ibidem.
} 
cresceu $115,2 \%$ entre 87 e 96 . 'O aumento no consumo dos alimentos prontos permite também outra interpretação: 0 brasileiro está comendo mais fora de casa. Não temos como medir isso em números, mas é possível fazer essa inferência', afirma a diretora do Departamento de Índice de Preços do IBGE, Márcia QuintsIr. A clássica dupla arroz com feijão, que aparece em faixas de renda diferenciadas, teve o consumo geral reduzido em $11 \%$.

A POF surge para determinar quais itens são importantes para calcular o IPCA. Com as mudanças no poder de compra da classe média e maior poder de planejamento da família, aliado ao desenvolvimento tecnológico, a reportagem mostra que a pesquisa aponta os celulares e computadores como os novos itens para compor o Índice ${ }^{264}$ :

A diretora do IBGE explicou que as mudanças têm como base a POF (Pesquisa de Orçamento Familiar) concluída em 1996. A pesquisa mostrou que itens como telefones celulares, computadores, planos de saúde e jogos lotéricos ganharam destaque no consumo das famílias. Eles passam a integrar a composição dos índices. Ao mesmo tempo, a POF de 96 mostrou que as famílias brasileiras estão gastando uma parte menor dos seus orçamentos com alimentos e vestuário, por exemplo. Esses produtos passarão a ter peso menor na hora de medir a variação do IPCA e do INPC.

Ao mesmo tempo a Revista Veja publica a reportagem "Pesquisa mostra que a mesa do brasileiro está mais farta, mas a qualidade da alimentação está ruim."265 O estudo, segundo a revista, constatou que o brasileiro estava comendo mais e atribui a isto o fim da inflação que diminuía o poder de compra, o aumento de empresas que fornecem tíquetes alimentação e a introdução de novas técnicas de cultivo. "Apesar da maior variedade e quantidade, continuamos nos alimentando mal', diz Maria Antonia Galeazzi,

\footnotetext{
264 "Celular e computadores entram no cálculo do IPCA". Folha de São Paulo. Dinheiro, 2 de julho de 1999. p. 28

265 VARELLA, Flavia. "Cardápio Renovado". Revista Veja, 23 de abril de 1997, p 47.
} 
professora da Unicamp"266. Essa categorização da alimentação entre boa e má é o tema que Michel Pollan trata em seu livro O Dilema do Onívoro. A imensa variedade que é oferecida a um onívoro, se por um lado oferece prazer e muita oportunidade, também causa estresse e a tendência da visão maniqueísta, dividindo o discurso em coisas boas e não boas para comer, como aparece na categorização "mal" da reportagem ${ }^{267}$.

Os números também mostram que os estereótipos regionais nem sempre se confirmam. Em 1998 a Revista Veja publica uma nota ${ }^{268}$ :

Churrasco no Tucupi. Engana-se quem acredita que Porto Alegre é a capital do consumo de carne para churrasco no Brasil. Esse título, segundo a última Pesquisa de Orçamentos Familiares, POF, do IBGE, pertence a uma cidade que fica mais ao norte: Belém, no Pará. Naquela capital, o consumo anual per capita de carne para churrasco chegou aos 22,3 quilos. Porto Alegre, com um consumo médio de 18 quilos por habitante, ficou em segundo lugar.

A terceira POF, realizada entre 2002/2003, foi feita em um momento de consolidação da política econômica do Plano Real, plano este que tinha acabado de ser implantado quando foi feita a pesquisa anterior. De forma geral, mantém-se a forte demanda de consumo, principalmente por novos itens tecnológicos, como celular e computador. Mas a aparente estabilidade não impede que $10,7 \%$ da população passe fome nessa época, segundo os dados da $\mathrm{FAO}^{269}$. A reportagem do jornal Folha de São Paulo mostra que o peso dos itens essenciais da alimentação, como arroz e feijão tiveram um aumento do peso no gasto familiar, em 1999 ele era de $0,97 \%$ e passou para $1,30 \%$ em $2002^{270}$. Mesmo assim, de forma geral, "os alimentos perderam espaço nos orçamentos e cederam lugar a gastos mais sofisticados. Itens como telefone

\footnotetext{
266 Idem, ibidem.

267 POLLAN, Michael. O Dilema do Onívoro, uma história natural de quatro refeições. Rio de Janeiro, Intrínseca, 2007. p. 12.

268 Revista Veja, 14 de janeiro de 1998, p. 18.

269 Organização das Nações Unidas para Alimentação e Agricultura (FAO). Disponível em: http://www.fao.org/hunger/en/ acessado em 15/10/2014.

270 SOARES, Pedro. "Gasto em internet supera arroz e feijão". Folha de São Paulo, Dinheiro, B10. 9 de janeiro de 2004.
} 
fixo, celular e energia elétrica ocupam hoje o lugar que no passado era deles." 271 Isso não quer dizer que os brasileiros estão comendo menos, mas sim que 0 item alimentação passou a ter um peso menor no orçamento doméstico. Porém, para $47 \%$ dos brasileiros os alimentos não são suficientes e para $85 \%$ das famílias responderam que é difícil chegar ao final do mês com o rendimento 272 . Foi a primeira vez que o IBGE se preocupou com essa questão na POF.

O leite é e continua sendo o alimento mais consumido do país, mesmo com a queda para $51,360 \mathrm{~kg}$ anuais e é também um marcador social -os mais abastados tomam seis vezes mais leite do que os pobres ${ }^{273}$. "As pessoas no Brasil tomam café, mas com leite depende da renda" colocou Wasmália Bivar, diretora de pesquisa do IBGE ${ }^{274}$. A mesma coisa acontece com a carne, com diferença de $86 \%$. No sentido oposto está o arroz e feijão. Os pobres consomem $28 \%$ e $40 \%$ a mais que os ricos, respectivamente ${ }^{275}$.

Pela casa podemos reconhecer de que classe social faz parte a família. (...) Olhemos para o que há de comer. Há só arroz, feijão, farinha, macarrão? Em que quantidade? O café de má qualidade, ralo, requentado a toda hora? Ou há, também, carne de vaca ou frango ou de porco? Há, na geladeira, leite e ovos à fartura, queijo, presunto, legumes, maças, peras e morangos?

A alimentação fora de casa cresceu muito desde o ENDEF considerando os gastos com alimentação, a refeição extra lar, que em 1974/1975 tinha um peso de 9.7\%, em 2002/2003 esse número passa para $24,05 \%$. O consumo de açúcar continua maior que o de feijão, sendo este de $12,97 \mathrm{~kg}$ per capita por ano enquanto o conjunto de feijões é 9,22kg para a média nacional. $\mathrm{Na}$ lista dos mais consumidos estão o leite, em primeiro lugar, depois arroz, carne bovina, frango, pão, açúcar e feijão. Itens como refrigerante

271 SOARES, Pedro \& BILLI, Marcelo. "Consumo supera renda em $85 \%$ das famílias". Folha de São Paulo, Dinheiro, B6, 20 de maio de 2004.

272 "Para 47\%, alimentos não são suficientes". Folha de São Paulo. Dinheiro, B7, 20 de maio de 2004.

273 IBGE. Pesquisa de Orçamentos Familiares 2002/2003. Rio de Janeiro, 2004.

274 "Ricos tomam 6 vezes mais leite que pobres". Folha de São Paulo, Dinheiro, B9, 20 de maio de 2004.

275 MELLO, João Manuel Cardoso de \& NOVAIS, Fernando. Op. Cit. p. 602. 
e óleo de soja estão na lista. O consumo de feijão entre os mais ricos é de $10,8 \mathrm{~kg}$ e os mais pobres $15,1 \mathrm{~kg}^{276}$. Importante diferenciar a lista por fornecimento de caloria e mais consumido por peso. Por exemplo, o açúcar é um importante fornecedor de caloria, sendo o maior no ENDEF, mas não precisa ser, necessariamente, o mais consumido se medido em peso, ficando atrás do leite, por exemplo.

O café tem o consumo mais homogêneo do país, independentemente da faixa de renda ou região. Mas alimentos como a farinha mandioca é regionalizado, sendo o produto mais consumido da região Norte, com $34,2 \mathrm{~kg}$. O Nordeste tem é a região que mais consome feijão, com 17,8kg, o estado que mais consome feijão é o Ceará, com 20,6kg mas também é muito consumido em Minas Gerais, 19,2kg. O Sudeste consome mais pão, sendo 14,8kg anuais. Em São Paulo esse número vai para 15,6kg e no Rio de Janeiro $18,1 \mathrm{~kg}^{277}$.

Comparando com o ENDEF, o aumento de consumo de produtos industrializados foi de $81 \%$ e o número de pessoas com excesso de peso quase triplicou neste período. Assim como fez na pesquisa anterior, a Revista Veja publica a matéria "Um país que come pior e está mais gordo." ${ }^{278}$ Traz mais dados sobre o consumo, como o refrigerante, que aumentou $393 \%$ no período ou salsichas e linguiças, com $189 \%{ }^{279}$. A pesquisa também é utilizada pela revista para desfazer alguns mitos regionais. Por exemplo, o consumo de macarrão: "É muito mais fácil encontrar macarrão em uma mesa de Recife, em Pernambuco, do que numa de São Paulo, cidade com grande número de descendentes de italianos"280. O jornal Folha de São Paulo não deixa de notar que a partir dessa pesquisa o IBGE volta a fazê-la em todo o território nacional e não apenas nas regiões metropolitanas: "Realizada pela primeira vez desde 1975 nas áreas urbanas e rurais do país, a pesquisa, feita em 2002 e 2003, detalha todos os gastos e a origem da renda da família"281

\footnotetext{
276 IBGE. Pesquisa de Orçamentos Familiares 2002/2003. Op. Cit.

277 Idem, ibidem.

278 Revista Veja, 22 de dezembro de 2004, p. 66.

279 Idem, ibidem.

280 Idem, ibidem.

281 SOARES, Pedro \& BILLI, Marcelo. "Consumo supera renda em $85 \%$ das famílias". Folha de São Paulo, Dinheiro, B6, 20 de maio de 2004.
} 
Da mesma forma aconteceu no último período, na POF de 2008/2009. Houve, nessa época, uma expansão dos programas sociais, aumento do salário mínimo e pequena redução da desigualdade. No mapa da fome isso se reflete com uma queda de $10,7 \%$ para menos de $5 \%$ em cinco anos ${ }^{282}$. Menos de $5 \%$ é o índice que a FAO considera como fora do mapa da fome, já que é muito difícil calcular abaixo desse percentual. Trabalhadores que antes eram miseráveis experimentam uma pequena sensação de ascensão social quando passam da extrema miséria rural para o trabalho na construção civil, por exemplo. Outros que saíram de trabalhos tidos como menos nobres, braçais, e entraram no escritório, incorporam novos hábitos de consumo.

As transformações se refletem nos números da pesquisa. Segundo o IBGE, de 2002/2003 para 2008/2009 a queda de alguns itens de consumo no âmbito nacional são notáveis. O arroz polido caiu $40,5 \%$, o feijão $26,4 \%$ e o açúcar $48,3 \%$. Enquanto isso, outros produtos ganharam espaço na mesa do brasileiro, como refrigerante de cola $(39,3 \%)$ e água mineral $(27,5 \%)^{283}$. A reportagem do IBGE traz uma comparação entre o rural e o urbano e nos mostra a diferença entre esses dois lugares -o consumo de bebidas e infusões no meio urbano é muito maior do que no meio rural $(55,2 \mathrm{~kg}$ para $28,9 \mathrm{~kg})$, assim como as frutas $(30,3 \mathrm{~kg}$ para $21,9 \mathrm{~kg})$. Outros alimentos, por sua vez, a proporção é invertida, como o consumo de cereais e leguminosas, que no meio urbano é $34,1 \mathrm{~kg}$ e no rural $62,5 \mathrm{~kg}$ e a carne, com $24,6 \mathrm{~kg}$ e $29,6 \mathrm{~kg}$ respectivamente. Maior diferença ainda está na comparação por renda, entre as classes de maior de menor rendimento. Em bebidas alcoólicas aparece a maior discrepância, de $799 \%$ (19,2 kg e 2,1 kg), em seguida vem alimentos

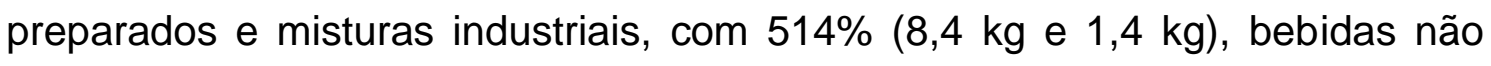
alcoólicas $401 \%$ (84,8 kg e 16,9\%) e iogurte, com 379\% (4,3 kg e 0,9kg).284 Há a tendência das classes mais abastadas consumirem gordura, leite e derivados, frutas e verduras em maior quantidade enquanto as menos

\footnotetext{
282 Organização das Nações Unidas para Alimentação e Agricultura (FAO). http://www.fao.org/hunger/en/ acessado em 15/10/2014.

283 IBGE. Brasileiro come menos arroz com feijão e mais comida industrializada. Disponível em: http://saladeimprensa.ibge.gov.br/noticias?view=noticia\&id=1\&busca=1\&idnoticia=1788 Acessado em 13/10/14.

284 Idem, ibidem.
} 
favorecidas se alimentam com mais leguminosas, como feijão, cereais raízes e tubérculos.

"Brasileiros consomem menos feijão com arroz e mais cerveja, aponta IBGE”285 é a notícia do canal G1, da Globo. A reportagem fala da divulgação dos dados do IBGE e comparada com a penúltima POF, de 2002/2003. Se fizermos uma comparação das últimas três décadas, vemos o aumento de $400 \%$ no consumo de produtos industrializados ${ }^{286}$. Para $35,5 \%$ das famílias há insuficiência de quantidade de alimentos consumidos, número menor que os $46,7 \%$ dos dados de 2003/2003.

Analisando desde o ENDEF, e portanto, apenas nas regiões metropolitanas, já que é o espaço geográfico que perpassa todas as pesquisas, identificamos quedas importantes, como o do arroz polido, com 60\% $(31,6 \mathrm{~kg}$ e $12,6 \mathrm{~kg}$ respectivamente), feijão, com 49\% e açúcar refinado, que passou de $15,8 \mathrm{~kg}$ para $3,3 \mathrm{~kg}$ na última pesquisa, uma redução de $79 \%{ }^{287}$. O aumento importante está nas carnes, com quase 50\%, frango, 100\%, biscoito $400 \%$ e refeições prontas, com $80 \%{ }^{288}$. O leite continua na liderança: "entre os alimentos tradicionalmente presentes no cardápio das famílias brasileiras, as maiores aquisições per capita anuais em 2008/2009 foram o leite de vaca pasteurizado (25,6 kg), carne bovina $(17,0 \mathrm{~kg})$ e arroz polido $(14,6 \mathrm{~kg})$ "289.

As mudanças nos hábitos alimentares domésticos durante o período analisado estão claras pelos dados das pesquisas de orçamentos familiares. Os motivos pelos quais elas aconteceram são inúmeros e até hoje pouco explorados, mas que podemos aqui enumerar alguns.

Um fator fundamental para a transformação do consumo doméstico de alimentos é o deslocamento da mulher para o campo de trabalho extra lar, além da mudança na configuração da família. Se antes esta era definida como

\footnotetext{
${ }^{285}$ G1, 16/12/2010, Disponível em: http://g1.globo.com/brasil/noticia/2010/12/brasileirosconsomem-menos-arroz-e-feijao-e-mais-cerveja-aponta-ibge.html acessado em 05/10/14. 286 IBGE. Pesquisa de Orçamentos Familiares 2002/2003 - Análise da disponibilidade domiciliar de alimentos e do estado nutricional no Brasil. Rio de Janeiro: IBGE, 2004. p. 40. 287 IBGE. Brasileiro come menos arroz com feijão e mais comida industrializada. Op. Cit. 288 IBGE. Pesquisa de Orçamentos Familiares 2002-2003 - Análise da disponibilidade domiciliar de alimentos e do estado nutricional no Brasil. Op. Cit. p. 37. 289 IBGE. Brasileiro come menos arroz com feijão e mais comida industrializada. Op. Cit.
} 
casal composto por homem, mulher e filhos, cresceram durante o período da pesquisa vínculos distintos, como, por exemplo, mãe e filhos sem o pai e viceversa. As transformações mais profundas ocorreram no interior do núcleo familiar, com o deslocamento do papeis e funções ${ }^{290}$. Se antes a mulher, em sua maioria, era detentora da responsabilidade das tarefas do espaço doméstico, e assim encarregada pela produção e reprodução da cultura alimentar, com a paulatina saída há uma "acefalia" neste âmbito. Porém, mesmo que a mulher tenha adquirido outras funções, sabemos que ela permanece, durante o período da pesquisa, responsável em grande parte pela operação familiar da alimentação, mesmo que ela também tenha adquirido outras funções. Na maioria dos lares, a mulher ainda é a responsável por essa tarefa - especificamente em $70 \%$ deles $^{291}$.

O saber culinário que antes era passado pela oralidade entre as mulheres na cozinha, agora recebe inúmeras influências. Essa lenta quebra do monopólio faz surgir outros parâmetros para esta prática, antes regida principalmente pela tradição. Partimos do princípio de que as mudanças causadas pelas Revoluções Tecnológicas aceleraram tais alterações dos costumes e o acesso a novos hábitos. Koselleck chama a atenção para uma transformação de paradigma fundamental para entender as alterações ocorridas com as inovações científicas. Antes, em um mundo agrário e artesanal, as expectativas estavam pautadas nas experiências dos antepassados que, por sua vez, iriam passando às próximas gerações. Quando algo mudava, tal mudança era tão lenta que a "ruptura entre a experiência adquirida até então e uma expectativa ainda por ser descoberta não chegava a romper o mundo da vida que se transmitia."292 A partir das Revoluções tecnológicas e da Revolução Francesa há uma paulatina mudança na perspectiva, do horizonte almejado. O progresso se torna a expectativa, algo ainda não vivido, algo novo que rompe com as experiências precedentes. Essa expectativa se modifica continuamente e de forma acelerada. "Tanto o

\footnotetext{
290 BERQUÓ, Elza. "Arranjos familiares no Brasil: uma visão demográfica". In: NOVAIS, Fernando, História da vida privada no Brasil - contrastes da intimidade contemporânea. São Paulo: Companhia das Letras, 1998. p. 439-488.

291 BARBOSA, Lívia. Op. Cit.

292 KOSELLECK, Reinhart. Op. Cit. p. 315.
} 
progresso sociopolítico quanto o progresso técnico-científico modificam os ritmos e prazos do mundo-da-vida graças à aceleração"293.

Este novo cenário abre espaço para discursos alimentares novos, como o estético, o médico-nutricional, o da tradição, o exótico e da diferença, o do progresso e da modernidade e o hedonista ${ }^{294}$. O alimento mostra, a partir do discurso adotado, uma expressão de processos sociais. Mesmo que o lar ainda seja elemento central para a alimentação, esta não é mais pautada principalmente pela tradição necessariamente. Há diversos pontos de vista que podem, inclusive, se sobrepor.

Neste sentido, um conceito que marcou os estudos sobre práticas alimentares no período contemporâneo é o de gastro-anomia proposto por Claude Fischler em seu texto $O$ onívoro 295 . Nele, o autor fala da desarticulação dos saberes e tradições alimentares em prol das pressões exercidas pelo mercado e pela imposição da escolha individual que está vinculada à dinâmica atual. Em outro estudo, Fischler escreve que a industrialização da alimentação está centrada nos Estados Unidos a partir do final do século XIX e se dissemina para outros lugares desenvolvidos logo depois, chegando, porém, aos países subdesenvolvidos mais tarde ${ }^{296}$. Este processo de industrialização mudou toda a cadeia alimentar - desde a agricultura até as formas de consumo. Fora isso, funções que antes estavam no âmbito doméstico, agora foram assimiladas por esta indústria, fazendo com que os alimentos já chegassem prontos para o consumo.

É válido ressaltar que não entendemos a perda total das habilidades culinárias. Este é um conceito mutável, pois o que é necessário em um dado tempo e espaço é diferente em outro. O peixe é um exemplo. Antes era necessária a identificação de frescor ou mesmo o conhecimento da pesca para adquirir o peixe. Hoje, além das características que definem o frescor, precisamos saber ler a embalagem, com prazo de validade, procedência e

293 Idem, ibidem. p. 321.

${ }^{294}$ ARNAIZ, Mabel Gracia. Paradojas de la alimentación contemporánea. Barcelona: Icaria, 1996.

295 FISCHLER, Claude. "Gastro-nomie et gastro-anomie: sagesse du corps et crise bioculturelle de l'alimentation moderne", em Communications, n 31, 1979.

296 FISCHLER, Claude. "Mcdonaldização dos costumes ..." Op. Cit. p. 845. 
outros signos. Dentro desse debate há os que apontam para a deterioração, na era da industrialização, destas habilidades, pois atualmente não se conhece o processo de transformação do alimento. Outra corrente defende, no entanto, que há uma mudança no repertório, transformação na própria aprendizagem culinária e nova gestão de horário. Existe um déficit no conhecimento sobre a cadeia produtiva do alimento, não se domina mais o percurso dele à mesa. Porém, esse processo não configura simplesmente uma perda, é a paulatina transformação das habilidades que, por mais débeis e insuficientes, existem e como tantas outras mudam ao longo do tempo. Faz-se necessária uma análise crítica para entender se estas habilidades da sociedade industrializada englobam os saberes básicos para a consciência alimentar e se a inserção do alimento como mercadoria dentro da dinâmica capitalista não afasta o comensal do caminho percorrido por ela.

O trabalho de mestrado de Débora Santos de Sousa Oliveira é ilustrativo deste processo aplicado ao caso brasileiro. A partir da análise de receitas do século $X X$, ela nos mostra como o leite condensado se transformou em base para a produção de doces e sobremesas no Brasil enquanto era incorporado nas receitas tradicionais, modificando-as. ${ }^{297} \mathrm{O}$ leite condensado foi paulatinamente ganhando espaço a partir de uma política empresarial e também por praticidade, tornando-se atualmente ingrediente fundamental na doçaria brasileira. Assim, outros alimentos que são essenciais e fazem parte do repertório alimentar vão perdendo espaço para outros que possuem campanhas publicitárias gigantescas. "Na ausência de campanhas publicitárias milionárias, como as produzidas pela indústria de alimentos prontos e redes de comida rápida, o feijão e alimentos básicos em geral são consumidos quando as pessoas ... sentem fome!"298.

O alimento se torna, assim como outros artigos, uma mercadoria dentro do sistema, para o consumo de massa - "transformados, processados, comercializados com técnicas modernas, produtos de massa." ${ }^{299}$ É um efeito conjugado da distribuição e da indústria. É muito mais vantajoso transportar

297 OLIVEIRA, Débora. Op. Cit.

298 MONTEIRO, Carlos Augusto. "Feijão, comida rápida e obesidade". Folha de São Paulo. 13 de junho de 2010, Primeiro Caderno, A3.

299 FISCHLER, Claude. "Mcdonaldização dos costumes...". Op. Cit. p. 858. 
aquele tipo de alimento que tem a capacidade de suportar um tempo maior, já que as distâncias percorridas em função da globalização e da produção aumentam cada vez mais.

O fast food marca esse processo, tornando até nome para ele "Mcdonaldização dos costumes"300. É a concretização do taylorismo, da divisão e racionalização nos restaurantes. Eles aparecem nos Estados Unidos nos anos 50 e vinte anos depois na Europa Ocidental e no resto do mundo ${ }^{301}$. São equipes que não detém a consciência do processo de produção, sem qualificação ou estudo, o que acarreta em baixa remuneração e procedimentos padronizados. Este tipo de refeição surge e se mantém para suprir principalmente duas tendências de comportamento. A primeira é o que Claude Fischler nomeia de smash and grab places que poderia ser traduzido por algo como lugares do esmaga e agarra ${ }^{302}$. Com a diminuição do tempo dedicado à refeição, consumir o alimento rapidamente vai ao encontro da demanda contemporânea. O segundo motivo é a higienização que, segundo Levestein, também seria responsável pelo sucesso das redes de fast food. A obsessão pela higiene que se instalou no pós-guerra e se espalhou. Este tipo de refeição se tornou tão disseminada que, segundo Jonh Vidal em seu livro McLibel burger, culture on Trial, $96 \%$ das crianças norte americanas reconhecem 0 Ronald McDonald's. Esse personagem só perde para o Papai Noel ${ }^{303}$.

Tudo o que representaram as novas formas de capitalismo no segundo pós-guerra foi prototípico do Mcdonalds: cultura do automóvel, ascensão das classes médias, consumo em massa de produtos descartáveis como símbolo do modo de vida, expansão do sistema de franquias, predomínio do setor de serviços, mas submetido a uma administração de características fabris, ou seja, a industrialização do entretenimento e do lazer, padronização da alimentação, importância crescente da

\footnotetext{
300 Idem, ibidem.

301 Idem, ibidem. p. 851.

302 Idem, ibidem. p. 852.

303 Apud FONTENELLE, Esleide - O nome da marca - Mc Donald's, fetichismo e cultura descartável. São Paulo: Boitempo, 2006. p. 34.
} 
propaganda (a era do marketing), o nome da marca tornando-se mais significativo do que o próprio produto. ${ }^{304}$

Claude Fischler emprega o que Edgar Morin aplica a indústria cultural. "O agrobusiness planetário não destrói, pura e simplesmente, as particularidades culinárias locais: desintegra e, ao mesmo tempo integra, produz uma espécie de mosaico sincrético universal (...) transforma os alimentos naturais locais em produtos culturais homogeneizados para 0 consumo maciço." ${ }^{305}$. Transformações das práticas alimentares não são exclusivas desta época, elas fazem parte de um processo inerente da sociedade que acompanha o acesso às outras formas de lidar com o meio e as paulatinas reinterpretações da relação do homem com a realidade que o cerca. Se no período recente estamos pautados em uma sociedade industrializada e globalizada, os hábitos alimentares tenderiam a acompanhar esta transformação social.

A "industrialização da alimentação, o progresso dos transportes, o advento da distribuição em larga escala, não tem como único objetivo desagregar e destruir as particularidades regionais." ${ }^{306}$. Ao mesmo tempo em que exclui, a globalização favorece e dá acesso a formação de especialidades locais. O aparente paradoxo é, na verdade, parte do mesmo processo, é a tendência de formação de grupos que reivindicam a manutenção e determinação do seu sistema alimentar. O eu em oposição ao outro amorfo, pasteurizado. Para Harvey a sociedade globalizada causa no cotidiano uma "compressão espaço-temporal". Com isso, há a aceleração do tempo e as fronteiras não são mais tão nítidas assim. ${ }^{307}$ Se por um lado o nacional não faz mais tanto sentido, por outro surgem grupos e movimentos que reforçam a sua identidade cultural, seja ela nacional ou regional.

Uma faceta diferente ligada ao desenvolvimento da indústria capitalista está vinculada ao desejo do homem de diferenciar-se. A revolução contínua da indústria alimenta o processo de diferenciação e de generalização do consumo.

304 CARNEIRO, Henrique. Comida e sociedade... Op. Cit. p. 107.

305 FISCHLER, Claude. "Mcdonaldização dos costumes...". Op. Cit. p. 858.

306 Idem, ibidem. p. 845.

307 HARVEY, David. The Condition of Postmodernity: na Enquiry into the Origins of Cultural Change. Oxford: Blackwell Publishers, 1990. 
É a tentativa de ascensão social e atualização dos bens de consumo entre os mais pobres em busca de uma equiparação com os ricos, que por sua vez, na tentativa de se distinguir dos outros, modificam permanentemente os bens e forma de consumo.

Segundo Celso Furtado esse movimento acontece no Brasil a partir de basicamente três mundos fraturados em uma sociedade deformada: o primeiro, dos magnatas, privilegiados que tentam adotar hábitos em comum com os seus pares do mundo desenvolvido e se remuneram muito bem; o segundo, da classe média mal paga por esse primeiro mundo que tenta ser uma imitação dele; e o terceiro mundo, dos pobres, muitas vezes miseráveis, escondidos nas periferias ${ }^{308}$.

O debate de fundo presente no livro Comer $^{309}$ está pautado nessa discussão da oposição "eu" e o "outro", levantando a crítica à realidade contemporânea. Os autores não tratam apenas do antagonismo França e Estados Unidos, eles analisam o eu coletivo em oposição ao eu indivíduo. A França como detentora e, principalmente, mantedora, da convivialidade e de refeições partilhadas enquanto os Estados Unidos aparecem como o expoente do individualismo e funcionalismo alimentar. "O modelo alimentar dos Estados Unidos (...) é simbolizado pela expansão das redes de fast-food, entre as quais o McDonald's assume, juntamente com a Coca-cola, a imagem pragmática dos logotipos mais emblemáticos da cultura capitalista contemporânea." ${ }^{310} \mathrm{E}$ apesar do hambúrguer, refrigerante e batata frita serem a caracterização deste modo de refeição, deste modo de vida, o funcionalismo alimentar aparece com muitas outras facetas, como a pizza, o cachorro quente ou a comida mexicana pasteurizada e vendida no drive-thru. Funcionalismo no sentido de praticidade. Porque podemos também entender como funcionalismo a tendência nutricional e das dietas restritivas que abafam o prazer e convivialidade, tornando o alimento meio para um objetivo prático.

308 FURTADO, Celso. Um projeto para o Brasil. Rio de Janeiro: Saga, 1968.

309 FISCHLER, Claude \& MASSON, Estelle - Comer: a alimentação dos franceses, outros europeus e americanos. São Paulo: Editora Senac São Paulo, 2010.

310 CARNEIRO, Henrique. Comida e sociedade... Op. Cit. p. 104. 
De forma ampla, podemos entender que as transformações alimentares mostradas nos dados das pesquisas de orçamentos familiares estão no bojo da introdução de uma nova realidade, que está pautada na queda de uma autoridade centrada principalmente na tradição para o florescimento de novos comportamentos e padrões de socialização e consumo, "além de transformações ocorridas na cultura material -o processo de urbanização, o surgimento de uma classe média, o desenvolvimento industrial, o aumento dos rendimentos, que (...) produziram mudanças dramáticas no estilo de vida." ${ }^{311} \mathrm{O}$ que marca esse recorte temporal é, segundo Hobsbawm, o triunfo do indivíduo sobre a sociedade ${ }^{312}$. 


\section{Capítulo 4}

\section{O feijão nas pesquisas sobre alimentação do IBGE}

Como vimos nos capítulos anteriores, o termo feijão é impreciso, ele comporta no mínimo dois gêneros, Phaseolus e Vigna, mais algumas exceções, como a espécie Cajanus Cajan, que tem o nome vulgar de feijãoguandu, feijão-andu, entre outros. Essa confusão léxica perpassa todo o período de pesquisa, sendo impreciso também a forma como os órgãos tratam deste alimento. Sabemos que, mesmo que ele não seja o mais consumido no país, como mostramos no capítulo 3 , é fundamental para tratarmos da alimentação do brasileiro, tema mostrado no primeiro capítulo. Assim, vamos entender como este alimento é consumido no âmbito doméstico entre os anos de 1973 e 2009 e como o IBGE compila estas informações.

Nosso objetivo é olhar para as mudanças ocorridas no período a partir do consumo efetivo no domicílio para debater sobre o papel do feijão na formação da identidade nacional à mesa. A representação identitária precisa ser, necessariamente, a partir do consumo efetivo abrangente e em grande quantidade ou ela pode se constituir a partir de um recorte que, ao mesmo tempo que te identifica, te distingue de outro grupo sem necessariamente ser 0 alimento consumido em maior quantidade?

Após a primeira pesquisa do nosso recorte, o ENDEF feito em 19731974, o IBGE publica em 1980 um estudo sobre os alimentos consumidos no Brasil, tanto vegetais quanto animais, para fins medicinais ou alimentares. É uma lista dos alimentos citados na pesquisa e separado por família e nome científico, uma tentativa de sistematização nos inúmeros nomes que as vezes compreendem a mesma espécie. Os feijões aparecem em Leguminosae e a partir de nome científico se coloca os nomes vulgares, como mostra a tabela abaixo ${ }^{313}$ :

\footnotetext{
${ }^{313}$ Para a seleção dos "feijões" descritos neste estudo foram separadas as leguminosas que tem feijão no nome vulgar e seus grãos são consumidos. Assim, a leguminosa feijão-batata que está descrita como hortaliça não entra na lista, da mesma forma que leguminosas consumidas em grãos mas que não recebem o nome de feijão, como as lentilhas. IBGE, Nomenclatura dos alimentos consumidos no Brasil - Parte 1 - vegetais. Rio de Janeiro, 1980.
} 


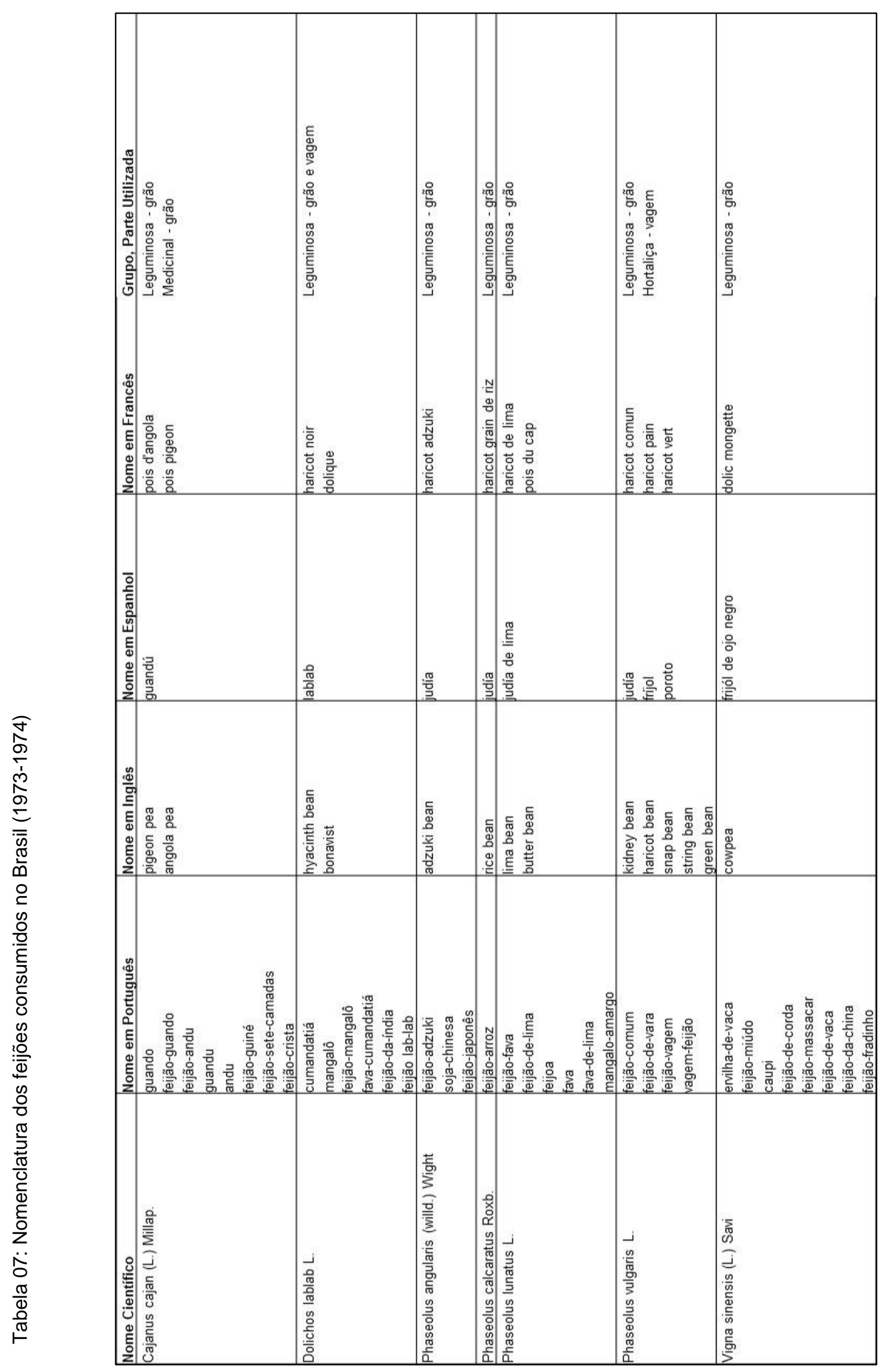


No anexo 2, o documento detalha as principais variedades de feijões dos gêneros mais consumidos Phaseolus vulgaris e Vigna sinensis ${ }^{314}$. E coloca a seguinte observação ${ }^{315}$ :

Devido ao grande número de cultivares (variedades) existentes no Brasil, as denominações popular e regional dos feijões causam certa confusão. É comum um mesmo cultivar receber diferentes nomes, bem como também cultivares distintos receberem a mesma denominação. Apesar disso, para o feijãocomum: Phaseolus vulgaris L., os principais cultivares comerciais podem ser classificados segundo grupos definidos, levando-se em conta a cor e o tamanho dos grãos. O mesmo não é possível ser feito com relação a ervilha-de-vaca: Vigna sinensis Endl., visto que esta espécie apresenta um grande número de formas difíceis de sistematização, até mesmo no campo das denominações regionais que se mostram muito variáveis.

O anexo apresenta a partir desta introdução as seguintes variedades listas abaixo ${ }^{316}$ :

\footnotetext{
314 Percebemos aqui mais uma diferença de léxico: os estudos recentes denominam Vigna unguiculata como a espécie do feijão-caupi, mas no texto do ENDEF eles tratam por Vigna sinensis. Segundo a $\mathrm{FAO}$, há uma divergência nas escolas quanto sua nomenclatura, enquanto Verdcourt of the Royal Botnical Gardens prefere Vigna unguiculata, termo mais utilizado, outros adotam Vigna sinensis. FAO, disponível em:

http://www.fao.org/ag/AGP/AGPC/doc/Gbase/data/pf000090.htm acessado 08/11/2014.

315 IBGE, Nomenclatura dos alimentos consumidos no Brasil - Parte 1 - vegetais. Op. Cit. p. 10

316 Idem, ibidem. p. 101-103.
} 


\begin{tabular}{|l|}
\hline $\begin{array}{l}\text { Phaseolus vulgaris (L.) (feijão- } \\
\text { comum) }\end{array}$ \\
\hline grupo "Bico de ouro" \\
\hline feijão-aeté \\
\hline feijão-bico \\
\hline feijão-bico-de-ouro \\
\hline feijão-caeté \\
\hline feijão-grão-de-ouro \\
\hline grupo "Chumbinho" \\
\hline feijão-argentino \\
\hline feijão-brilhante \\
\hline feijão-café \\
\hline feijão-cafezinho \\
\hline feijão-caqui \\
\hline feijão-cara-suja \\
\hline feijão-caturra \\
\hline feijão-chumbinho \\
\hline feijão-chumbinho-brilhante \\
\hline feijão-chumbinho-opaco \\
\hline feijão-de-lastro \\
\hline feijão-fumaça \\
\hline feijão-gargau \\
\hline feijão-imperial \\
\hline feijão-lustroso \\
\hline feijão-lustroso-paranaense \\
\hline feijão-macaquinho \\
\hline feijão-mulatinho-chumbinho \\
\hline feijão-mulato \\
\hline feijão-nova-planta \\
\hline feijão-opaco \\
\hline feijão-opaquinho \\
\hline feijão-paco-mineiro \\
\hline feijão-paquinha \\
\hline feijão-paquinho \\
\hline feijão-pardinho \\
\hline feijão-pardo \\
\hline feijão-serra-azul \\
\hline feijão-terrinha \\
\hline feijão-tupi \\
\hline feijão-veadinho \\
\hline grupo "Manteiga" \\
\hline feijão-amarelo \\
\hline feijão-amendoim \\
\hline feijão-baeta \\
\hline feijão-baetão \\
\hline
\end{tabular}




\begin{tabular}{|l|}
\hline feijão-bico-canga \\
\hline feijão-bolinha \\
\hline feijão-bolinha-do-sul \\
\hline feijão-branco \\
\hline feijão-branco-rasteiro \\
\hline feijão-branco-uberlândia \\
\hline feijão-cachinho \\
\hline feijão-cachinho-de-ouro \\
\hline feijão-cacho-de-coco \\
\hline feijão-canarinho \\
\hline feijão-carioca \\
\hline feijão-carnaval \\
\hline feijão-casca-de-coco \\
\hline feijão-cascão \\
\hline feijão-cavalo-claro \\
\hline feijão-cavalo-escuro \\
\hline feijão-chocolate \\
\hline feijão-come-calado \\
\hline feijão-creme \\
\hline feijão-curió \\
\hline feijão-curiscão \\
\hline feijão-da-rainha \\
\hline feijão-de-janeiro \\
\hline feijão-do-sul \\
\hline feijão-do-sul-amarelo \\
\hline feijão-do-sul-rajado \\
\hline feijão-do-sul-vermelho \\
\hline feijão-douradinho \\
\hline feijão-encarnado \\
\hline feijão-engorda-mulher \\
\hline feijão-enrica-homem \\
\hline feijão-enxofrão \\
\hline feijão-enxofre \\
\hline feijão-fígado-de-galinha \\
\hline feijão-fígado-de-ganso \\
\hline feijão-fogo-na-serra \\
\hline feijão-frango \\
\hline feijão-galantão \\
\hline feijão-goiano-precoce \\
\hline feijão-gordinho \\
\hline feijão-gordo \\
\hline feijão-gordura \\
\hline feijão-grosso \\
\hline feijão-ipanema \\
\hline feijão-jalinho \\
\hline
\end{tabular}




\begin{tabular}{|l|}
\hline feijão-jalo \\
\hline feijão-janeiro \\
\hline feijão-japão \\
\hline feijão-jaula \\
\hline feijão-jaula-amarelão \\
\hline feijão-lavandeira \\
\hline feijão-louça \\
\hline feijão-mamoninha \\
\hline feijão-mandubim \\
\hline feijão-manteiga \\
\hline feijão-manteiga-da-bahia \\
\hline feijão-manteiga-74 \\
\hline feijão-manteiguinha \\
\hline feijão-massa-fina \\
\hline feijão-mineiro \\
\hline feijão-mineiro-amarelo \\
\hline feijão-mineirinho \\
\hline feijão-moleque \\
\hline feijão-moura \\
\hline feijão-olho-de-peixe \\
\hline feijão-olho-de-pomba \\
\hline feijão-ouro \\
\hline feijão-passarico \\
\hline feijão-pestaninha \\
\hline feijão-pintadinho \\
\hline feijão-pintadinho-precoce \\
\hline feijão-pintado \\
\hline feijão-pitocão \\
\hline feijão-polo-sul \\
\hline feijão-rainha \\
\hline feijão-rajadinho \\
\hline feijão-rajado \\
\hline feijão-rajado-menor \\
\hline feijão-rio-de-janeiro \\
\hline feijão-riscadinho \\
\hline feijão-safra-nova \\
\hline feijão-sangue-de-tatu \\
\hline feijão-siririca \\
\hline feijão-sobrancelha-de-moça \\
\hline feijão-verde-vermelho \\
\hline feijão-vermelho \\
\hline feijão-vermelho-branco \\
\hline feijão-zebrinha \\
\hline grupo "Mulatinho" \\
\hline feijão-bage-roxa \\
\hline
\end{tabular}




\begin{tabular}{|l|} 
feijão-boca-funda \\
\hline feijão-caboclinho \\
\hline feijão-caboclo \\
\hline feijão-café-com-leite \\
\hline feijão-catiara \\
\hline feijão-cinquentinha \\
\hline feijão-cofelista \\
\hline feijão-creme-60-dias \\
\hline feijão-de-arranca \\
\hline feijão-do-paraná \\
\hline feijão-sul-marrom \\
\hline feijão-enrica-homem \\
\hline feijão-favinha \\
\hline feijão-fígado \\
\hline feijão-gordo-de-arranca \\
\hline feijão-japonês \\
\hline feijão-mamãe \\
\hline feijão-não-curta \\
\hline feijão-marrom \\
\hline feijão-marrom-tico-tico \\
\hline feijão-marronzinho \\
\hline feijão-mata-mulher \\
\hline feijão-minguita \\
\hline feijão-minguito \\
\hline feijão-moreninho \\
\hline feijão-mouro \\
\hline feijão-mulata-gorda \\
\hline feijão-mulatão \\
\hline feijão-mulatinho \\
\hline feijão-mulatinho-caianinha \\
\hline feijão-mulatinho-checê \\
\hline feijão-mulatinho-paulista \\
\hline feijão-mulatinho-precoce \\
\hline feijão-mulatinho-simétrico \\
\hline feijão-mulatinho-1208 \\
\hline feijão-nagé \\
\hline feijão-navegador-marrom \\
\hline feijão-paina \\
\hline feijão-paininha \\
\hline feijão-paranazinho \\
\hline feijão-paulista \\
\hline feijão-pé-curto \\
\hline feijão-penquinha \\
\hline feijão-piratã \\
\hline feijão-rim-de-porco \\
\hline
\end{tabular}




\begin{tabular}{|l|}
\hline feijão-santa-rosa \\
\hline feijão-sela-cavalo \\
\hline feijão-60-dias \\
\hline feijão-tico-tico-pintado \\
\hline feijão-vagem-branca \\
\hline feijão-vagem-listrada \\
\hline feijão-vagem-mooco \\
\hline feijão-vagem-roxa \\
\hline grupo "Preto" \\
\hline feijão-bandinha \\
\hline feijão-barão \\
\hline feijão-bata \\
\hline feijão-beira-linha \\
\hline feijão-bordão \\
\hline feijão-caqui-crioulo \\
\hline feijão-cavalo \\
\hline feijão-copinha \\
\hline feijão-costa-rica \\
\hline feijão-de-cor \\
\hline feijão-de-milho \\
\hline feijão-do-sul \\
\hline feijão-escurinho \\
\hline feijão-floresta-5 \\
\hline feijão-floresta-negra \\
\hline feijão-goiano \\
\hline feijão-guamerim \\
\hline feijão-lastro \\
\hline feijão-leste \\
\hline feijão-liso-do-sul \\
\hline feijão-maragatinho \\
\hline feijão-mineirinho \\
\hline feijão-novinho \\
\hline feijão-paina \\
\hline feijão-paraná \\
\hline feijão-porto-alegre \\
\hline feijão-preto-120 \\
\hline feijão-preto-143 \\
\hline feijão-preto-8-e-9 \\
\hline feijão-puiuiu \\
\hline feijão-quebrancho \\
\hline feijão-rapacuia \\
\hline feijão-rebenta-negro \\
\hline feijão-rico-23 \\
\hline feijão-seleção-cuva-168N \\
\hline feijão-taquari \\
\hline
\end{tabular}




\begin{tabular}{|l|}
\hline feijão-tipo-penca \\
\hline feijão-tipo-novo \\
\hline feijão-uberabinha \\
\hline feijão-vagem-preta \\
\hline feijão-vagem-riscada \\
\hline feijão-vagem-risco \\
\hline feijão-venezuela-350 \\
\hline grupo "Rosinha" \\
\hline feijão-barrozinho \\
\hline feijão-batatinha \\
\hline feijão-corado \\
\hline feijão-fazendão \\
\hline feijão-gancheiro \\
\hline feijão-mãezinha \\
\hline feijão-maria-rosa \\
\hline feijão-mini-rosinha \\
\hline feijão-mofado-natoo \\
\hline feijão-moura-rosa \\
\hline feijão-paquetá \\
\hline feijão-pitanga \\
\hline feijão-rosa \\
\hline feijão-rosado \\
\hline feijão-rosado-guaranésia \\
\hline feijão-rosa-mato-grosso \\
\hline feijão-rosinha \\
\hline feijão-rosinha-EEP-45726 \\
\hline feijão-rosinha-G2 \\
\hline feijão-rosinha-mato-grosso \\
\hline feijão-rosinha-paulista \\
\hline feijão-rosinha-sem-cipó \\
\hline feijão-vinagre \\
\hline grupo "Roxo" \\
\hline feijão-anão \\
\hline feijão-bico-roxo \\
\hline feijão-bico-roxo-precoce \\
\hline feijão-bordô \\
\hline feijão-brabinho \\
\hline feijão-de-cor \\
\hline feijão-lambe-beiço \\
\hline feijão-marumbé \\
\hline feijão-rapé \\
\hline feijão-rochedo \\
\hline feijão-roxão \\
\hline feijão-roxão-lustroso \\
\hline feijão-roxinho \\
\hline
\end{tabular}




\begin{tabular}{|l|} 
feijão-roxinho-bico-roxo \\
\hline feijão-roxinho-itumbiara \\
\hline feijão-roxinho-opaco \\
\hline feijão-roxinho-precoce \\
\hline feijão-roxinho-ribeirão \\
\hline feijão-roxo \\
\hline feijão-roxoti \\
\hline feijão-vermelhão \\
\hline grupo "Outros" \\
\hline feijão-agulha \\
\hline feijão-amarelinho \\
\hline feijão-amarelinho-atibaia \\
\hline feijão-carioquinha \\
\hline feijão-carrapatinho \\
\hline feijão-carrapato \\
\hline feijão-chuveiro-de-prata \\
\hline feijão-coruja \\
\hline feijão-corujinha \\
\hline feijão-esperança \\
\hline feijão-frango \\
\hline feijão-franguinho \\
\hline feijão-mafra \\
\hline feijão-maracá \\
\hline feijão-morrinho \\
\hline feijão-morro \\
\hline feijão-mourinho \\
\hline \\
\hline Vigna sinensis Endl. (ervilha-de- \\
vaca) \\
\hline feijão-alagoano \\
\hline feijão-alfange \\
\hline feijão-amarelo \\
\hline feijão-aparecido \\
\hline feijão-baianinho \\
\hline feijão-baiano \\
\hline feijão-baige-roxa \\
\hline feijão-bajão \\
\hline feijão-balaio \\
\hline feijão-barrigudinho \\
\hline feijão-barrigudinho-vermelho \\
\hline feijão-barrigudo \\
\hline feijão-bengala \\
\hline feijão-boca-amarela \\
\hline feijão-boca-preta \\
\hline
\end{tabular}




\begin{tabular}{|l|}
\hline feijão-branquinho \\
\hline feijão-bufão \\
\hline feijão-cabrito-roxo \\
\hline feijão-canapu \\
\hline feijão-carrapicho \\
\hline feijão-casca-frouxa \\
\hline feijão-catador \\
\hline feijão-catador-rajado \\
\hline feijão-caupi \\
\hline feijão-chico-de-barro \\
\hline feijão-chicote \\
\hline feijão-chinês \\
\hline feijão-colônia \\
\hline feijão-coruja \\
\hline feijão-coruja-do-sul \\
\hline feijão-costela-de-vaca \\
\hline feijão-da-china \\
\hline feijão-da-colônia \\
\hline feijão-da-estrada \\
\hline feijão-da-praia \\
\hline feijão-da-praia-marrom \\
\hline feijão-de-corda \\
\hline feijão-de-corda-barrigudo \\
\hline feijão-de-corda-branco \\
\hline feijão-de-corda-manteiga \\
\hline feijão-de-corda-sacaninha \\
\hline feijão-de-corda-vermelho \\
\hline feijão-de-frade \\
\hline feijão-de-metro \\
\hline feijão-de-moita \\
\hline feijão-de-olho-preto \\
\hline feijão-de-rama \\
\hline feijão-de-vaca \\
\hline feijão-de-vagem \\
\hline feijão-de-vara \\
\hline feijão-do-rio \\
\hline feijão-enrica-homem \\
\hline feijão-estrada \\
\hline feijão-frade-comprido \\
\hline feijão-fradinho \\
\hline feijão-gurgutuba \\
\hline feijão-gurgutuba-catador \\
\hline feijão-gurutuba \\
\hline feijão-gurutuba-comprido \\
\hline feijão-leite \\
\hline
\end{tabular}




\begin{tabular}{|l|} 
feijão-ligeiro \\
\hline feijão-lisão-novo \\
\hline feijão-macassã \\
\hline feijão-massacar \\
\hline feijão-malhado \\
\hline feijão-manteiguinha \\
\hline feijão-marrom-colônia \\
\hline feijão-milagroso \\
\hline feijão-miudinho \\
\hline feijão-miúdo \\
\hline feijão-miúdo-novo \\
\hline feijão-olho-de-cabra \\
\hline feijão-olho-de-ovelha \\
\hline feijão-orelha-de-frade \\
\hline feijão-pardo \\
\hline feijão-pendanga \\
\hline feijão-pernambucano \\
\hline feijão-peruano \\
\hline feijão-pitiuba \\
\hline feijão-Porto-rico \\
\hline feijão-potomac \\
\hline feijão-pretinho \\
\hline feijão-40-dias \\
\hline feijão-40-dias-pretinho \\
\hline feijão-40-dias-preto \\
\hline feijão-40-dias-vermelho \\
\hline feijão-40-horas \\
\hline feijão-quarentinha \\
\hline feijão-quebra-cadeira \\
\hline feijão-quebra-garrancho \\
\hline feijão-rabo-de-peba \\
\hline feijão-rabo-de-tatu \\
\hline feijão-rajado \\
\hline feijão-rasteiro \\
\hline feijão-sacaninha \\
\hline feijão-santarém \\
\hline feijão-sempre-verde \\
\hline feijão-seridó \\
\hline feijão-tombadinho \\
\hline feijão-tripa-de-porco \\
\hline feijão-vagem-roxa \\
\hline feijão-vagem-verde \\
\hline feijão-vazante \\
\hline feijão-verde \\
\hline feijão-vermelho \\
\hline
\end{tabular}




\begin{tabular}{|l|} 
feijão-vermelho-de-vazante \\
\hline feijão-vinagre \\
\hline
\end{tabular}

São trezentos e noventa e cinco nomes. Alguns se repetem nos distintos gêneros, como "feijão-enriquece-homem", mas, como explica a observação do IBGE, às vezes variedades diferentes ganham designações iguais, ou, ao contrário, a mesma variedade pode apresentar dois nomes diferentes, principalmente se mudar a região.

$\mathrm{Na}$ tentativa de mapear alguma sistematização e regionalização, o ENDEF coloca em alguns feijões enumerados na lista de códigos o lugar de maior incidência. Nessa tabela, os dois primeiros números designam o gênero do alimento, como 05 - leguminosas. $O$ terceiro e quarto dígitos identificam o alimento dentro deste gênero. Em um primeiro momento eles foram dispostos em ordem alfabética mas depois foram relacionados em ordem de ocorrência. O quinto dígito indica a forma ou estado em que o alimento foi encontrado. No caso das leguminosas quer dizer:

$$
\begin{aligned}
& 0 \text { - não determinado, } \\
& 1 \text { - com casca, } \\
& 2 \text { - sem casca, } \\
& 3 \text { - cozido, } \\
& 4 \text { - frito, } \\
& 5 \text { - fécula, } \\
& 6 \text { - farinha, } \\
& 7 \text { - doces, } \\
& 8 \text { - biscoitos, } \\
& 9 \text { - bolos }{ }^{317} \text {. }
\end{aligned}
$$

Tabela 08: lista dos códigos dos alimentos ENDEF318

\begin{tabular}{|c|l|}
\hline Código & Alimento \\
\hline 05030 & feijão manteiga \\
\hline & feijão louca (RS) \\
\hline
\end{tabular}

317 IBGE. Códigos de alimentos do ENDEF. Rio de Janeiro, 1974. p. 04.

318 Idem, ibidem, p 24-27. 


\begin{tabular}{|l|l|}
\hline & feijão branco \\
\hline & feijão canarinho (SP) \\
\hline & feijão engorda mulher (GO) \\
\hline & feijão japão (MG) \\
\hline & feijão massa fina (MG) \\
\hline & feijão pitocão (MG) \\
\hline & feijão rainha (MG) \\
\hline & feijão ipanema (MG) \\
\hline & feijão de janeiro (SE) \\
\hline & feijão enrica homem (SE) \\
\hline & feijão olho de pomba (SP) \\
\hline 05031 & feijão branco em vagem (seco) \\
\hline 05032 & feijão manteiga (grão) \\
\hline 05034 & feijão branco com dobradinha em lata \\
\hline & dobradinha com feijão branco em lata \\
\hline 05040 & feijão bico de ouro \\
\hline & feijão caete (RJ) \\
\hline & feijão pingo de ouro (PA) \\
\hline & feijão grão de ouro (SC) \\
\hline 05042 & feijão bico de ouro (Grão) \\
\hline 05050 & feijão mulatinho (SC, AL, SE, PB, PE, SP) \\
\hline & feijão cofelista (MT) \\
\hline & feijão paulista \\
\hline & feijão mouro (Santa Catarina) \\
\hline & feijão navegador marrom (PA) \\
\hline & feijão sessenta dias (MG) \\
\hline & feijão mulata gorda (CE) \\
\hline & feijão nage (BA) \\
\hline & feijão creme sessenta dias (RS) \\
\hline & feijão cinquentinha (MG) \\
\hline & feijão vagem monooco (BA) \\
\hline & feijão marrom tico-tico (ES) \\
\hline & feijão mamãe (MG) \\
\hline & feijão fígado (PB) \\
\hline & feijão moreninho (SP) \\
\hline & feijão penquinha (MG) \\
\hline & feijão caboclinho (RJ) \\
\hline & feijão tico-tico pintado (RJ) \\
\hline & feijão minguito (MG) \\
\hline & feijão mula preto \\
\hline & feijão borbão (MG) rebenta negro (MG) \\
\hline & feijão de milho (MG) \\
\hline & \\
\hline & \\
\hline &
\end{tabular}




\begin{tabular}{|l|l|}
\hline & feijão beira linha (MG) \\
\hline & feijão floresta negra (BA) \\
\hline & feijão escurinho (BA) \\
\hline & feijão leste (ES) \\
\hline & feijão paina (ES) \\
\hline & feijão maragatinho (RS) \\
\hline & feijão quebrancho (RJ) \\
\hline & feijão liso do sul (PA) \\
\hline & feijão rapacuia (MG) \\
\hline 05061 & feijão preto em vagem (seco) \\
\hline 05062 & feijão preto (grão) \\
\hline 05064 & feijoada em lata \\
\hline 05070 & feijão macassar \\
\hline & feijão corda \\
\hline & feijão de metro \\
\hline & feijão fradinho \\
\hline & feijão orelha de frade (leguminosa) \\
\hline & feijão do rio (MA) \\
\hline & feijão ibra (MG) \\
\hline & feijão de rama (MG) \\
\hline & feijão baiano (MG) \\
\hline & feijão catador \\
\hline & feijão catador \\
\hline & feijão vinagre (MA) \\
\hline & feijão coruja (PA) \\
\hline & feijão sempre verde \\
\hline & feijão vagem roxa (AL) \\
\hline & feijão vazante (CE) \\
\hline & feijão lisão novo (CE) \\
\hline & feijão cirido (CE) \\
\hline & feijão cabrito roxo (CE) \\
\hline & feijão pitiuba (CE) \\
\hline & feijão rabo de peba (CE) \\
\hline & feijão de moita (CE) \\
\hline & feijão de corda barrigudinho (CE) \\
\hline & feijão peruano (CE) \\
\hline & feijão leite (MA) \\
\hline & feijão quarentinha (MA) \\
\hline & feijão pendanga (MA) \\
\hline & feijão tombadinho (MG) \\
\hline & feijão quebra cadeira (CE) \\
\hline & feijão miudo novo (MG) \\
\hline & feijão colonia (PA) \\
\hline & feijão ligeiro manteiguinha (PI) \\
\hline & \\
\hline &
\end{tabular}




\begin{tabular}{|l|l|}
\hline & feijão de vara (SP) \\
\hline & feijão maraca (BA) \\
\hline & feijão quebra garrancho (BA) \\
\hline 05071 & feijão de corda seco em vagem \\
\hline 05072 & feijão macassar (grão) \\
\hline 05078 & feijão de corda verde em vagem \\
\hline 05080 & guando \\
\hline & andu \\
\hline & feijão guiné (PB) \\
\hline & feijão sete camadas (SP) \\
\hline & feijão crista (SP) \\
\hline 05082 & guando (grão) \\
\hline 05083 & guando cozido \\
\hline & andu cozido \\
\hline 05090 & feijão cavalo \\
\hline & feijão do paraná \\
\hline 05092 & feijão cavalo (grão) \\
\hline 05100 & feijão \\
\hline 05102 & feijão (grão) \\
\hline 05103 & feijão de qualquer tipo cozido \\
\hline 05108 & doce de feijão tipo caseiro \\
\hline 05109 & doce de feijão industrializado \\
\hline & \\
\hline
\end{tabular}

Dos feijões consumidos regionalmente temos uma grande variedade mineira, sendo este estado que apresenta o maior consumo específico de feijão. Nele podíamos encontrar no início da década de 70 o feijão-japão, feijão-massa-fina, feijão-pitocão, feijão-rainha, feijão-ipanema, feijão-sessentadias, feijão-cinquentinha, feijão-mamãe, feijão-de-milho, feijão-beira-linha, feijão-borbão, feijão-rebenta-negro, feijão-minguito, feijão-miudo-novo, feijãotombadinho, feijão-rapacuia, feijão-ibra, feijão-de-rama e feijão-baiano. Outros estados que apresentam grande número de variedades particulares são Ceará e Bahia. No Ceará encontramos o feijão-mulata-gorda, feijão-quebra-cadeira, feijão-vazante, feijão-lisão-novo, feijão-cirido, feijão-cabrito-roxo, feijão-pitiuba, feijão-rabo-de-peba, feijão-de-moita, feijão-de-corda-barrigudinho, feijãoperuano; e na Bahia o feijão-nage, feijão-vagem-monooco, feijão-café-comleite, feijão-floresta-negra, feijão-escurinho, feijão-maraca e feijão-quebragarrancho. Não por acaso esses estados também apresentam um alto consumo de feijão. Quando o alimento se torna parte do cotidiano familiar, que nesse período era plantado muitas vezes na própria terra, ele adquire maior 
probabilidade de desdobramentos de nomes vulgares ou mesmo novas espécies.

Para a divulgação dos resultados o IBGE apresenta os principais grupos consumidos: feijão-preto, feijão-mulatinho, feijão-de-corda, feijão-roxo e depois outros feijões. Apesar de o primeiro da tabela ser o feijão manteiga e ela supostamente estar em ordem de ocorrência, segundo os resultados apresentados pelo ENDEF o feijão mais consumido no Brasil em 1973-1974 é o de corda com 15,4kg anuais. Em segundo lugar vem o mulatinho $(13,6 \mathrm{~kg})$ e depois o preto com 12,9319. A apresentação dos números aparece em quatro partes e é dividido por região ${ }^{320}$. Compilamos o consumo de feijão na tabela a seguir:

Tabela 09: consumo de feijão por região e áreas metropolitanas - 1973 -1974 (kg/ano) ${ }^{321}$ :

\begin{tabular}{|l|r|r|r|r|r|}
\hline Regiões & $\begin{array}{l}\text { Feijão } \\
\text { preto }\end{array}$ & $\begin{array}{l}\text { Feijão } \\
\text { Mulatinho }\end{array}$ & $\begin{array}{l}\text { Feijão de } \\
\text { corda }\end{array}$ & $\begin{array}{l}\text { Feijão } \\
\text { roxo }\end{array}$ & \multicolumn{1}{c|}{$\begin{array}{l}\text { Outros } \\
\text { feijões }\end{array}$} \\
\hline Região I - Rio de Janeiro & 15,9 & 1,2 & 0,2 & 0,1 & 2,6 \\
\hline Região II - São Paulo & 0,4 & 4,3 & 0,2 & 9,9 & 5,5 \\
\hline Região III - Sul & 11,4 & 1,9 & 1 & 3,3 & 4,8 \\
\hline Região IV - Minas Gerais e Espírito Santo & 4,9 & 3,9 & 1,2 & 5,5 & 10,4 \\
\hline Região V - Nordeste & 0,4 & 9,4 & 15,9 & 0,9 & 4,3 \\
\hline Região VI - Distrito Federal & 2,4 & 0,7 & 0,1 & 15,6 & 1,5 \\
\hline Região VII - Rondônia, Acre, Amazonas, & & & & & \\
Roraima, Pará, Amapá, Goiás e Mato Grosso & 1,2 & 0,8 & 0,4 & 6,6 & 5,9 \\
\hline Áreas metropolitanas & & & & & \\
\hline Rio de Janeiro & 16 & 0,9 & 0,2 & 0,1 & 2,2 \\
\hline Curitiba & 10,7 & 1,5 & 0 & 0,6 & 3,9 \\
\hline Porto Alegre & 10,9 & 0,5 & 0,1 & 0 & 1,9 \\
\hline Fortaleza & 0,1 & 5,8 & 17,4 & 0,2 & 0,7 \\
\hline Recife & 0,4 & 14,2 & 0,8 & 0 & 1 \\
\hline Salvador & 0,1 & 14,6 & 0,4 & 0 & 1,7 \\
\hline São Paulo & 0,5 & 2,8 & 0,1 & 10,4 & 4,7 \\
\hline Belo Horizonte & 0,9 & 0,6 & 0,1 & 4,8 & 9,5 \\
\hline Belém & 0,8 & 0,3 & 0,5 & 0,1 & 8,9 \\
\hline
\end{tabular}

319 VASCONCELOS, Maurício Teixeira Leite de. Op. Cit. p. 88.

320 IBGE. ENDEF - Dados Preliminares. Consumo Alimentar - Antropometria. Região I e Região III. Rio de Janeiro, 1977; IBGE. ENDEF - Dados Preliminares. Consumo Alimentar Antropometria. Região V. Rio de Janeiro, 1977; IBGE. ENDEF - Dados Preliminares. Consumo Alimentar - Antropometria. Região II e Região IV. Rio de Janeiro, 1977; IBGE. ENDEF - Dados Preliminares. Consumo Alimentar - Antropometria. Região VI e Região VII. Rio de Janeiro, 1977.

321 Idem, ibidem. 
O feijão-carioca, tão presente nas outras pesquisas, não é sequer citado entre os principais feijões. Aparece apenas na lista geral mencionada anteriormente. Como colocamos no segundo capítulo, isso acontece porque ele é uma variedade nova, que teria surgido em São Paulo no contexto dessa primeira pesquisa, ainda não tendo se disseminado como alimento. O feijãopreto é muito consumido no Rio de Janeiro e na região Sul. Na região Nordeste há duas variedades: enquanto em Recife e Salvador o feijão-moreninho é presente, em Fortaleza o feijão-de-corda tem maior destaque. Já em São Paulo o mais consumido é o feijão-roxo.

O feijão-rajado, embora não citado entre os mais consumidos, aparece especificado na primeira Pesquisa de Orçamento Familiar (POF), em 1987/1988, a segunda a ser analisada. Ele, assim como o carioca, é uma variedade relativamente recente, que aparece como expressivo apenas nas pesquisas posteriores. Como explicado no terceiro capítulo, quando o IBGE formulou a POF, o órgão adotou uma metodologia diferente da do ENDEF, não se importando com a assimilação nutricional, e sim com a aquisição alimentar especificamente em formar o índice de preços ao consumidor-, e se restringiu apenas às regiões metropolitanas, mais Distrito Federal e Goiana. Aqui, apesar destas restrições na concepção da pesquisa e na divulgação dos resultados, o IBGE detalha mais os principais tipos de feijão consumidos, como aparece na tabela a seguir ${ }^{322:}$

322 IBGE. Pesquisa de Orçamentos Familiares 1987/1988. Op. Cit. p. 32. 


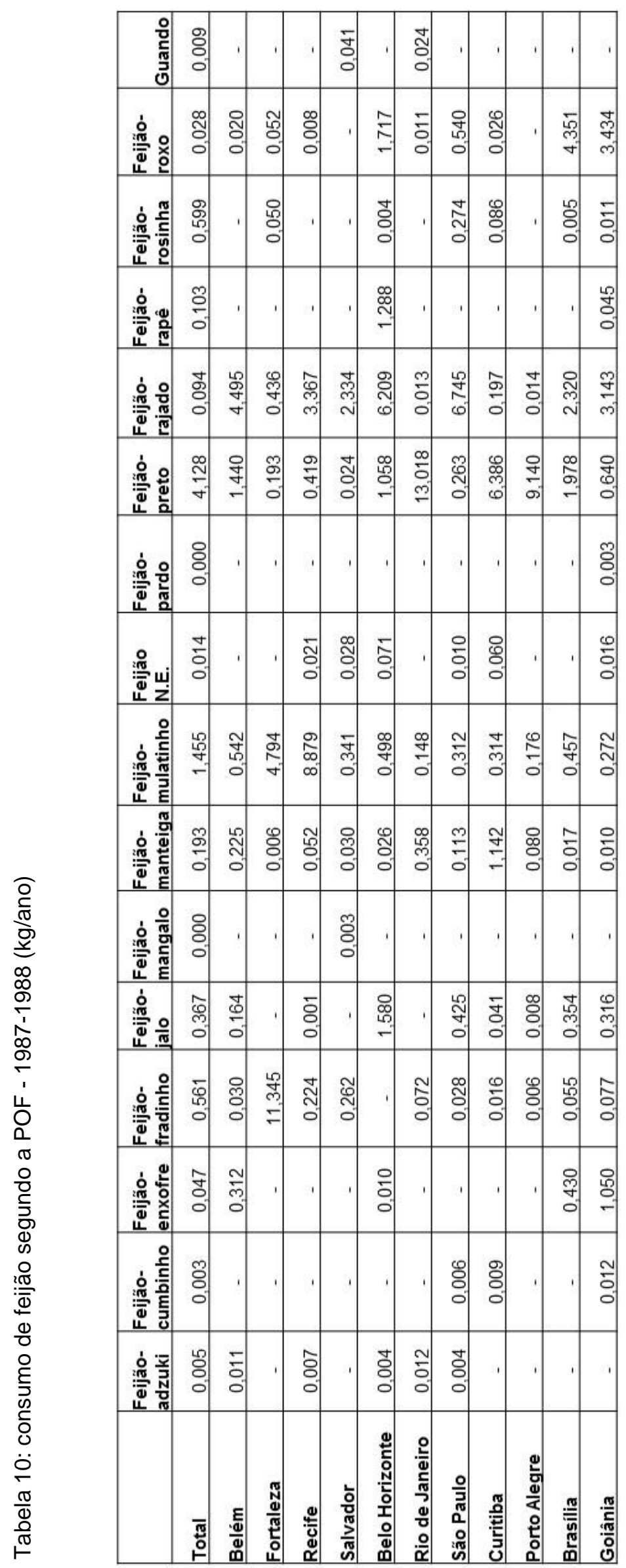


Como podemos perceber, o feijão-carioca ainda não aparece na pesquisa, outros feijões têm o protagonismo, como o preto, que é o mais consumido, seguido do feijão-mulatinho e do feijão-fradinho. O feijão-fradinho tem um alto consumo em Fortaleza, $11,345 \mathrm{~kg}$ por ano per capita e o feijãomulatinho continua sendo muito consumido no Recife, mas sofreu uma queda abrupta em Belo Horizonte, passando de 14,6 kg para 0,3 kg. O feijão-rajado pode ser uma das explicações, ele já aparece na lista tendo alto consumo em Belém, Belo Horizonte, São Paulo, Goiânia e Recife e Salvador. Apesar de pertencerem a grupos diferentes, o feijão-rajado e o feijão-carioca aparecem sob o mesmo nome de "rajado" nas pesquisas posteriores. Por isso é difícil afirmar com exatidão quando o feijão-carioca foi aceito no mercado nacional, tema que colocamos no segundo capítulo, mas podemos supor que sob o nome de feijão-rajado já havia o consumo de carioca. Temos também que levar em consideração que apenas as áreas metropolitanas são consideradas nesta pesquisa, e esses números na área rural tende a ser diferente, principalmente quando tratamos de leguminosas.

Já na divulgação dos resultados da POF de 1995/1996, o IBGE coloca apenas o termo feijão para medirmos o consumo, além de este ser medido em moeda, não em quilos. Como a preocupação da POF era a formação do índice de preços, a divulgação desses resultados está focada nesse objetivo. Por isso, a construção da tabela foi feita a partir do gasto médio mensal com o produto. Ele é demonstrado por renda média das famílias, como mostra a tabela na página a seguir.

No geral, esta POF é descrita por renda, mas há algumas poucas análises na introdução da divulgação dos resultados que mostram o consumo em quilos por ano:

Tabela 11: Consumo de feijão nas regiões metropolitanas Brasil - 1995-1996 (kg/ano) ${ }^{323}$

\begin{tabular}{|l|r|}
\hline & Feijão (kg/ano) \\
\hline Total & 9,945 \\
\hline Belém & 9,857 \\
\hline Fortaleza & 15,191 \\
\hline
\end{tabular}

323 IBGE, Pesquisa de Orçamentos Familiares 1995/1996. Rio de Janeiro, 1997. p. 42. 


\begin{tabular}{|l|r|}
\hline Recife & 12,428 \\
\hline Salvador & 12,51 \\
\hline Belo Horizonte & 9,344 \\
\hline Rio de Janeiro & 14,307 \\
\hline São Paulo & 6,556 \\
\hline Curitiba & 8,436 \\
\hline Porto Alegre & 6,515 \\
\hline Brasília & 10,947 \\
\hline Goiânia & 7,028 \\
\hline
\end{tabular}

Percebemos que há um aumento do consumo de feijão em Brasília e no Rio de Janeiro e uma diminuição em várias outras regiões metropolitanas, como Porto Alegre, São Paulo, Goiânia e Belo Horizonte. E constata: "enfocando os resultados do total das áreas (média), destaca-se o aumento do consumo de biscoito (28,02\%), frango (16,56\%), carne bovina de segunda $(6,95 \%)$ e carne bovina de primeira (5,97\%), e diminuição do consumo de farinha de trigo $(29,73 \%)$, leite de vaca $(19,31 \%)$, cereais -arroz polido $(16,56 \%)$ e feijão $(15,56 \%)^{\prime 324}$.

Segundo esta pesquisa, nas regiões metropolitanas do Brasil, o maior gasto com feijão vem das famílias com faixa de renda de cinco a seis salários mínimos, com dispêndio médio de $R \$ 4,49$. O preço do quilo do alimento estava, em São Paulo, $R \$ 1,46$ na data base desta POF, 15 de setembro de $1996^{325}$. Esta foi a primeira medição após a implantação do Plano Real. Desde 1994, quando a moeda foi trocada, houve uma variação no preço de $31 \%$. Nos anos anteriores, durante a primeira POF, essa variação foi de $254 \%{ }^{326}$, por, entre outros fatores, a alta inflação. Também temos que considerar que houve, nesse contexto, a implantação de uma nova moeda, a passagem do Cruzeiro para o Cruzado. Isso mostra que a tentativa de controlar os preços, que no contexto da primeira POF não foram bem sucedidas, como mostra o jornal Folha de São Paulo em reportagem de 06 de maio de 1987: "Custo de vida sobre $13,78 \%$, maior taxa mensal depois do cruzado":

\footnotetext{
324 IBGE, Pesquisa de Orçamentos Familiares 1995/1996. Op. Cit. p. 41.

325 Instituto de Economia Agrícola - Banco de Dados. Disponível em:

http://ciagri.iea.sp.gov.br/nia1/precos medios.aspx?cod sis=4 Acessado 05/10/2014.

326 Idem, ibidem.
} 


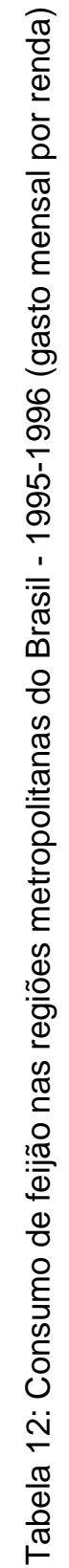

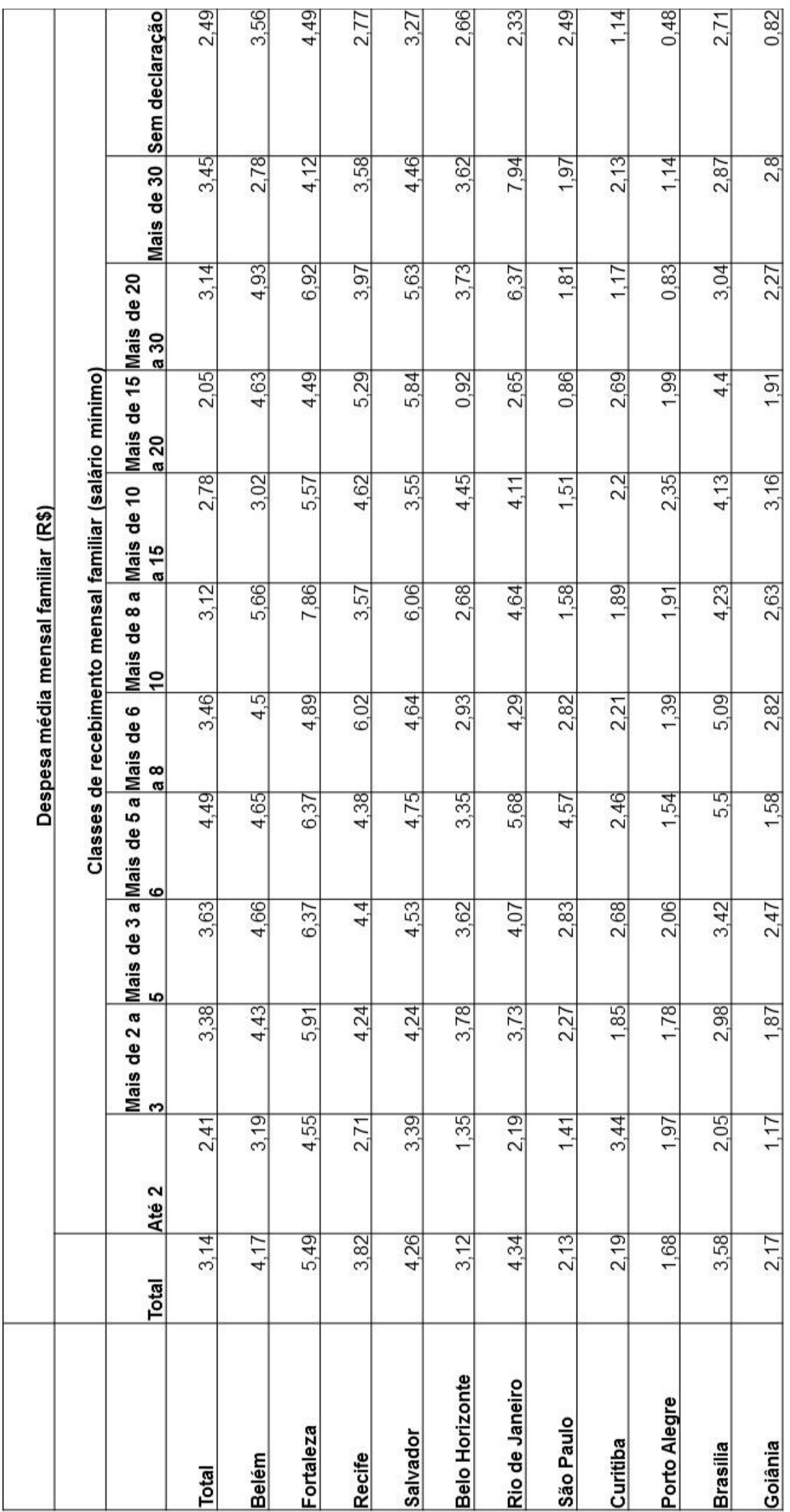


"(...) os cereais, com tendência de alta desde o início de março, subiram 20\% na quadrissemana. O quilo do arroz passou a custar mais $16 \%$, e o do feijão $59 \% . " 327$

Uma variação de $59 \%$ em tão pouco tempo representa uma ameaça no orçamento doméstico. Após a implantação do Plano Real e até a POF de 1996/1997 não houve tamanha alta dos preços. Porém, uma das grandes elevações veio em 1998, não pelo fator inflação, mas por uma queda na produção de $23 \%$. Para conter um pouco o valor, ocorreu o aumento da importação em $33 \%$, comparado com o ano anterior e como mostramos no segundo capítulo ${ }^{328}$. Claro que esse déficit na produção não passou despercebido no mercado e, mesmo com o aumento da importação, o feijão teve uma alta nos preços de mais de $40 \%$ ao longo do ano ${ }^{329}$. Em 09 de maio de 1998 é publicada uma notícia sobre a elevação do valor do feijão em mais $30 \%$ nos supermercados de São Paulo, mesmo que outros produtos tenham ficado estáveis. O motivo, segundo o jornal, é a queda na safra provocada pelo fenômeno El Niño. No atacado, a alta no ano girou em torno de $250 \%{ }^{330}$. No ano eleitoral, esse não deixou de ser um dos temas da campanha. $O$ aumento da importação foi lido como uma das formas que o governo encontrou para conter o aumento dos alimentos, principalmente do feijão ${ }^{331}$.

Essa flutuação de preço não se ateve apenas nesse período. Em 2007 também há outro grande aumento - que chegou a 149,5\%. Esse valor lidera as variações do ano pelos cálculos da FIPE (Fundação Instituto de Pesquisas Econômicas ${ }^{332}$. Mais uma vez, o motivo foram as mudanças climáticas. A grande estiagem trouxe a queda da produção e consequente aumento do preço. Podemos notar que a vulnerabilidade da produção de feijão causa uma variação grande. Com foi tratado no capítulo passado, a falta de atenção governamental para os pequenos produtores, a baixa produtividade e pouco

\footnotetext{
327 "Custo de vida sobre 13,78\%, maior taxa mensal depois do cruzado". Folha de São Paulo. Economia, A 24, 06 de maio de 1987.

328 Organização das Nações Unidas para Alimentação e Agricultura (FAO). Op. Cit.

329 Instituto de Economia Agrícola - Banco de Dados. Op. Cit.

330 "Feijão sobre 30\% nos supermercados de SP". Folha de São Paulo. Dinheiro, 02, 09 de maio de 1998. p. 3.

331 "A reação de FHC às pesquisas". Folha de São Paulo. Brasil, 1. 25 de junho de 1998.

332 Instituto de Economia Agrícola - Banco de Dados. Op. Cit.
} 
acesso a novas tecnologias são alguns dos fatores que geram essa inconstância. $O$ incentivo à importação se torna um paliativo para a falta de política direcionada ao longo do período da pesquisa. O feijão apresenta uma demanda de elasticidade negativa, isso quer dizer há uma tendência de, quanto menor a renda, maior o consumo do produto. Por isso, sabemos que as famílias mais pobres são as que gastam a maior porcentagem da renda com este alimento e com a alimentação em geral. Consequentemente, a intensa variação no preço atinge a faixa mais pobre, tornando-a suscetível a sua flutuação.

Se as duas primeiras POF estavam focadas nas regiões metropolitanas e na formação do INPC, as seguintes abrangeram o país todo e colocaram maiores detalhes na sua divulgação. As duas últimas POF, de 2002/2003 e 2008/2009 especificaram de quais tipos de feijão estamos tratando. Segundo o documento do IBGE ${ }^{333}$,

Componentes das linhas da tabela da despesa monetária e não monetária média mensal familiar, com alimentação", define que feijão corresponde aos códigos: 63012 a 63017, 63019, 63021 a 63026, 63031, 63046.

Se formos levantar todas as nomenclaturas, nestas pesquisas, para a agência de estatística, feijão é caracterizado por:

Tabela 13: códigos correspondentes a feijão segundo a POF 2002/2003334

\begin{tabular}{|l|l|l|l|}
\hline \multicolumn{3}{|c|}{ Código } & \multicolumn{1}{c|}{ Nome } \\
\hline 63 a 69 & 63 & 1201 & Fava (em grão) \\
\hline 63 a 69 & 63 & 1202 & Fava de Lima (em grão) \\
\hline 63 a 69 & 63 & 1203 & Feijoa (em grão) \\
\hline 63 a 69 & 63 & 1204 & Mangalo Amargo (em grão) \\
\hline 63 a 69 & 63 & 1205 & Feijão Fava em grão \\
\hline 63 a 69 & 63 & 1301 & Feijão Manteiga \\
\hline 63 a 69 & 63 & 1302 & Feijão Bico de Ouro \\
\hline 63 a 69 & 63 & 1303 & Feijão Caete \\
\hline 63 a 69 & 63 & 1304 & Feijão Pingo de Ouro \\
\hline 63 a 69 & 63 & 1305 & Feijão Grão de Ouro \\
\hline
\end{tabular}

333 IBGE. Pesquisa de Orçamentos Familiares, 2008/2009. Op. Cit.

334 Essa tabela aparenta ser o recolhimento da nomenclatura feita pelos moradores que preencheram as cadernetas de consumo. Idem, ibidem. 


\begin{tabular}{|c|c|c|c|}
\hline 63 a 69 & 63 & 1306 & Feijão Branco \\
\hline 63 a 69 & 63 & 1307 & Feijão Louca \\
\hline 63 a 69 & 63 & 1308 & Feijão Canarinho \\
\hline 63 a 69 & 63 & 1309 & Feijão Bolinha \\
\hline 63 a 69 & 63 & 1310 & Feijão Pitoco \\
\hline 63 a 69 & 63 & 1311 & Feijão Douradinho \\
\hline 63 a 69 & 63 & 1401 & Feijão Mulatinho \\
\hline 63 a 69 & 63 & 1402 & Feijão Cofelista \\
\hline 63 a 69 & 63 & 1403 & Feijão Paulista \\
\hline 63 a 69 & 63 & 1404 & Feijão Mouro \\
\hline 63 a 69 & 63 & 1405 & Feijão Sessenta Dias \\
\hline 63 a 69 & 63 & 1406 & Feijão Mulata Gorda \\
\hline 63 a 69 & 63 & 1407 & Feijão Marrom \\
\hline 63 a 69 & 63 & 1408 & Feijão Moreninho \\
\hline 63 a 69 & 63 & 1409 & Feijão Café com Leite \\
\hline 63 a 69 & 63 & 1410 & Feijão Nage \\
\hline 63 a 69 & 63 & 1411 & Feijão Navegador Marrom \\
\hline 63 a 69 & 63 & 1412 & Feijão Cearense \\
\hline 63 a 69 & 63 & 1501 & Feijão Preto \\
\hline 63 a 69 & 63 & 1502 & Feijão Escurinho \\
\hline 63 a 69 & 63 & 1503 & Feijão Floresta Negra \\
\hline 63 a 69 & 63 & 1504 & Feijão Borbão \\
\hline 63 a 69 & 63 & 1505 & Feijão Quebrancho \\
\hline 63 a 69 & 63 & 1506 & Feijão Rebenta Negro \\
\hline 63 a 69 & 63 & 1507 & Feijão do Milho \\
\hline 63 a 69 & 63 & 1508 & Feijão Beira Linha \\
\hline 63 a 69 & 63 & 1509 & Feijão Italianinho \\
\hline 63 a 69 & 63 & 1510 & Feijão Bandinha Preto \\
\hline 63 a 69 & 63 & 1511 & Feijão Cavalo \\
\hline 63 a 69 & 63 & 1512 & Feijão de cor \\
\hline 63 a 69 & 63 & 1513 & Feijão Preto Bandinha \\
\hline 63 a 69 & 63 & 1601 & Feijão Fradinho \\
\hline 63 a 69 & 63 & 1602 & Feijão Macassar \\
\hline 63 a 69 & 63 & 1603 & Feijão de Corda \\
\hline 63 a 69 & 63 & 1604 & Feijão Orelha de Metro \\
\hline 63 a 69 & 63 & 1605 & Feijão Orelha de Frade \\
\hline 63 a 69 & 63 & 1606 & Feijão Coruja \\
\hline 63 a 69 & 63 & 1607 & Feijão de Moita \\
\hline 63 a 69 & 63 & 1608 & Feijão Quarentinha \\
\hline 63 a 69 & 63 & 1609 & Feijão Ligeiro \\
\hline 63 a 69 & 63 & 1610 & Feijão Catador \\
\hline 63 a 69 & 63 & 1611 & Feijão Miúdo \\
\hline 63 a 69 & 63 & 1612 & Feijão Gurgutuba \\
\hline 63 a 69 & 63 & 1613 & Feijão Gurutuba \\
\hline 63 a 69 & 63 & 1614 & Feijão Olho de Cabra \\
\hline 63 a 69 & 63 & 1615 & Feijão Pendanga \\
\hline 63 a 69 & 63 & 1616 & Feijão Pitiuba \\
\hline 63 a 69 & 63 & 1617 & Feijão Quarenta Dias \\
\hline
\end{tabular}




\begin{tabular}{|c|c|c|c|}
\hline 63 a 69 & 63 & 1618 & Feijão Boca Preta \\
\hline 63 a 69 & 63 & 1619 & Feijão de Frade \\
\hline 63 a 69 & 63 & 1620 & Feijão de Vara \\
\hline 63 a 69 & 63 & 1621 & Feijão de Olho Preto \\
\hline 63 a 69 & 63 & 1622 & Feijão do Rio \\
\hline 63 a 69 & 63 & 1623 & Feijão Ibra \\
\hline 63 a 69 & 63 & 1624 & Feijão de Rama \\
\hline 63 a 69 & 63 & 1625 & Feijão Baiano \\
\hline 63 a 69 & 63 & 1626 & Feijão Vinagre \\
\hline 63 a 69 & 63 & 1627 & Feijão Sempre Verde \\
\hline 63 a 69 & 63 & 1628 & Feijão de Arranca \\
\hline 63 a 69 & 63 & 1629 & Feijão Baje Podre (Macassar) \\
\hline 63 a 69 & 63 & 1630 & Feijão Barrigudo (de metro) \\
\hline 63 a 69 & 63 & 1631 & Feijão Canapu \\
\hline 63 a 69 & 63 & 1632 & Feijão Caupí \\
\hline 63 a 69 & 63 & 1633 & Feijão da Colônia \\
\hline 63 a 69 & 63 & 1634 & Feijão Verde \\
\hline 63 a 69 & 63 & 1635 & Feijão Peruano \\
\hline 63 a 69 & 63 & 1636 & Feijão Trepa Pau \\
\hline 63 a 69 & 63 & 1701 & Feijão Jalo \\
\hline 63 a 69 & 63 & 1702 & Feijão Vermelho \\
\hline 63 a 69 & 63 & 1703 & Feijão Moleque \\
\hline 63 a 69 & 63 & 1704 & Feijão Encarnado \\
\hline 63 a 69 & 63 & 1705 & Feijão Gordo \\
\hline 63 a 69 & 63 & 1706 & Feijão Enxofrão \\
\hline 63 a 69 & 63 & 1707 & Feijão do Sul \\
\hline 63 a 69 & 63 & 1901 & Feijão Roxo \\
\hline 63 a 69 & 63 & 1902 & Feijão Rochedo \\
\hline 63 a 69 & 63 & 1903 & Feijão Bico Roxo \\
\hline 63 a 69 & 63 & 1904 & Feijão Bordo \\
\hline 63 a 69 & 63 & 1905 & Feijão Brabinho \\
\hline 63 a 69 & 63 & 1906 & Feijão Marumbe \\
\hline 63 a 69 & 63 & 1907 & Feijão Roxinho \\
\hline 63 a 69 & 63 & 1908 & Feijão Roxão \\
\hline 63 a 69 & 63 & 1909 & Feijão Roxoti \\
\hline 63 a 69 & 63 & 1910 & Feijão Rapé (Roxo) \\
\hline 63 a 69 & 63 & 1911 & Feijão Anão (Roxo) \\
\hline 63 a 69 & 63 & 2101 & Feijão Rajado \\
\hline 63 a 69 & 63 & 2102 & Feijão Amendoim \\
\hline 63 a 69 & 63 & 2103 & Feijão Chita Fina \\
\hline 63 a 69 & 63 & 2104 & Feijão Vermelho e Branco \\
\hline 63 a 69 & 63 & 2105 & Feijão Zebrinha \\
\hline 63 a 69 & 63 & 2106 & Feijão Casca de Coco \\
\hline 63 a 69 & 63 & 2107 & Feijão Cascão \\
\hline 63 a 69 & 63 & 2108 & Feijão Pintado \\
\hline 63 a 69 & 63 & 2109 & Feijão Pintadinho \\
\hline 63 a 69 & 63 & 2110 & Feijão Riscadinho \\
\hline 63 a 69 & 63 & 2111 & Feijão Carnaval \\
\hline
\end{tabular}




\begin{tabular}{|l|l|l|l|}
\hline 63 a 69 & 63 & 2112 & Feijão Grosso \\
\hline 63 a 69 & 63 & 2113 & Feijão Chocolate \\
\hline 63 a 69 & 63 & 2114 & Feijão Carioca \\
\hline 63 a 69 & 63 & 2115 & Feijão Rajadinho \\
\hline 63 a 69 & 63 & 2116 & Feijão Carioquinha \\
\hline 63 a 69 & 63 & 2201 & Feijão Rosinha \\
\hline 63 a 69 & 63 & 2202 & Feijão Maria Rosa \\
\hline 63 a 69 & 63 & 2203 & Feijão Moura Rosa \\
\hline 63 a 69 & 63 & 2204 & Feijão Rosado \\
\hline 63 a 69 & 63 & 2205 & Feijão Barrosinho \\
\hline 63 a 69 & 63 & 2206 & Feijão Gancheiro \\
\hline 63 a 69 & 63 & 2207 & Feijão Paqueta \\
\hline 63 a 69 & 63 & 2301 & Feijão Enxofre \\
\hline 63 a 69 & 63 & 2302 & Feijão Amarelo \\
\hline 63 a 69 & 63 & 2303 & Feijão Ouro \\
\hline 63 a 69 & 63 & 2304 & Feijão Mineiro Amarelo \\
\hline 63 a 69 & 63 & 2305 & Feijão Mineiro \\
\hline 63 a 69 & 63 & 2401 & Feijão Pardo \\
\hline 63 a 69 & 63 & 2402 & Feijão Fumaça \\
\hline 63 a 69 & 63 & 2501 & Feijão Chumbinho \\
\hline 63 a 69 & 63 & 2502 & Feijão Cafezinho \\
\hline 63 a 69 & 63 & 2503 & Feijão Paquinho \\
\hline 63 a 69 & 63 & 2504 & Feijão Paco Mineiro \\
\hline 63 a 69 & 63 & 2505 & Feijão Caqui \\
\hline 63 a 69 & 63 & 2506 & Feijão Opaquinho \\
\hline 63 a 69 & 63 & 2507 & Feijão Café \\
\hline 63 a 69 & 63 & 2508 & Feijão Terrinha \\
\hline 63 a 69 & 63 & 2509 & Feijão Cara Suja \\
\hline 63 a 69 & 63 & 2510 & Feijão Opaco \\
\hline 63 a 69 & 63 & 2511 & Feijão Fígado de Galinha \\
\hline 63 a 69 & 63 & 2512 & Feijão Imperial \\
\hline 63 a 69 & 63 & 2601 & Guando \\
\hline 63 a 69 & 63 & 2602 & Andu \\
\hline 63 a 69 & 63 & 2603 & Guandu \\
\hline 63 a 69 & 63 & 2604 & Feijão Guando \\
\hline 63 a 69 & 63 & 2605 & Feijão Andu \\
\hline 63 a 69 & 63 & 2606 & Feijão Guine \\
\hline 63 a 69 & 63 & 2607 & Feijão Crista \\
\hline 63 a 69 & 63 & 2608 & Feijão Sete Camadas \\
\hline 63 a 69 & 63 & 2609 & Feijão Guandu \\
\hline 63 a 69 & 63 & 3101 & Feijão Não Especificado \\
\hline 63 a 69 & 63 & 3102 & Feijão (não especificado) \\
\hline 63 a 69 & 63 & 4601 & Feijão da Praia \\
\hline
\end{tabular}

Na divulgação de resultados da pesquisa, o IBGE, no entanto, coloca de forma diferente. Na pesquisa de 2002/2003 há o agrupamento entre os tipos: 
feijão-fradinho, feijão-jalo, feijão-manteiga, feijão-preto, feijão-rajado, feijão-roxo e outros feijões. O feijão-rajado (e nele embutido o feijão-carioca) aparece como o grande protagonista, com um pouco mais de 5 quilos por ano e não sendo o mais consumo apenas no Sul e no Nordeste, onde ganha o consumo de feijão-preto e feijão-fradinho, respectivamente. Com a preocupação com todo o território nacional e não apenas com as regiões metropolitanas, é nesse formato que o IBGE apresenta a divulgação dos resultados:

Tabela 14: aquisição domiciliar de feijão - 2002/2003 (kg/ano) ${ }^{335}$

\begin{tabular}{|c|c|c|c|c|c|c|c|c|}
\hline & $\begin{array}{l}\text { Feijão- } \\
\text { fradinho }\end{array}$ & $\begin{array}{l}\text { Feijão- } \\
\text { jalo }\end{array}$ & $\begin{array}{l}\text { Feijão- } \\
\text { manteiga }\end{array}$ & $\begin{array}{l}\text { Feijão- } \\
\text { mulatinho }\end{array}$ & $\begin{array}{l}\text { Feijão- } \\
\text { preto }\end{array}$ & $\begin{array}{l}\text { Feijão- } \\
\text { rajado }\end{array}$ & $\begin{array}{l}\text { Feijão- } \\
\text { roxo }\end{array}$ & $\begin{array}{l}\text { Outros } \\
\text { feijões }\end{array}$ \\
\hline Brasil & 1,577 & 0,441 & 0,325 & 0,709 & 2,891 & 5,077 & 0,085 & 1,289 \\
\hline Norte & 0,776 & 0,812 & 0,251 & 0,128 & 1,023 & 5,280 & 0,101 & 1,757 \\
\hline Nordeste & 5,343 & 0,362 & 0,824 & 2,335 & 1,977 & 5,297 & 0,105 & 1,041 \\
\hline Sudeste & 0,037 & 0,617 & 0,062 & 0,088 & 2,582 & 6,077 & 0,058 & 1,525 \\
\hline Sul & 0,031 & 0,062 & 0,291 & 0,036 & 6,766 & 1,247 & 0,011 & 0,827 \\
\hline $\begin{array}{l}\text { Centro- } \\
\text { Oeste }\end{array}$ & 0,056 & 0,067 & 0,084 & 0,055 & 2,340 & 5,939 & 0,316 & 1,292 \\
\hline Rondônia & 0,132 & 0,056 & 0,076 & 0,409 & 1,557 & 6,070 & 0,028 & 1,791 \\
\hline Acre & 0,592 & 0,421 & 0,643 & 0,178 & 1,497 & 4,384 & 0,332 & 1,691 \\
\hline Amazonas & 0,128 & 0,986 & 0,070 & 0,081 & 0,680 & 3,320 & 0,055 & 2,605 \\
\hline Roraima & 0,063 & 0,344 & 0,151 & 0,353 & 1,624 & 2,276 & - & 3,436 \\
\hline Pará & 1,463 & 1,045 & 0,408 & 0,082 & 0,850 & 6,486 & 0,037 & 0,644 \\
\hline Amapá & & 0,770 & & 0,069 & 3,453 & 4,154 & 0,032 & 0,754 \\
\hline Tocantins & 0,097 & 0,374 & 0,003 & 0,094 & 0,704 & 4,512 & 0,590 & 5,566 \\
\hline Maranhão & 2,035 & 1,611 & 3,406 & 1,816 & 1,245 & 0,399 & 0,165 & 1,381 \\
\hline Piauí & 8,463 & 2,309 & 3,356 & 0,857 & 0,607 & 1,062 & 0,168 & 4,069 \\
\hline Ceará & 15,522 & 0,009 & 0,368 & 1,378 & 0,400 & 1,659 & 0,302 & 0,706 \\
\hline $\begin{array}{c}\text { Rio } \\
\text { Grande }\end{array}$ & 4,586 & 0,499 & 0,813 & 1,178 & 2,007 & 4,460 & 0,034 & 0,976 \\
\hline
\end{tabular}

${ }^{335}$ Idem, ibidem. 


\begin{tabular}{|c|c|c|c|c|c|c|c|c|}
\hline do Norte & & & & & & & & \\
\hline Paraíba & 8,229 & 0,037 & 0,613 & 1,978 & 1,468 & 7,187 & 0,006 & 0,259 \\
\hline $\begin{array}{l}\text { Pernam- } \\
\text { buco }\end{array}$ & 3,695 & - & 0,002 & 4,380 & 2,051 & 5,043 & 0,066 & 1,141 \\
\hline Alagoas & 1,370 & 0,003 & 0,097 & 1,758 & 2,088 & 8,193 & 0,029 & 1,654 \\
\hline Sergipe & 0,000 & 0,008 & - & 1,662 & 5,007 & 5,805 & - & 1,188 \\
\hline Bahia & 2,256 & & 0,237 & 2,753 & 3,141 & 9,592 & 0,048 & 0,433 \\
\hline $\begin{array}{l}\text { Minas } \\
\text { Gerais }\end{array}$ & 0,065 & 2,430 & 0,003 & 0,054 & 1,842 & 12,475 & 0,165 & 1,362 \\
\hline $\begin{array}{c}\text { Espírito } \\
\text { Santo }\end{array}$ & 0,020 & 0,227 & 0,166 & 0,055 & 3,659 & 1,631 & 0,015 & 3,286 \\
\hline $\begin{array}{c}\text { Rio de } \\
\text { Janeiro }\end{array}$ & 0,057 & 0,000 & 0,028 & 0,137 & 7,513 & 0,253 & & 1,256 \\
\hline São Paulo & 0,018 & 0,017 & 0,095 & 0,089 & 0,948 & 5,623 & 0,032 & 1,558 \\
\hline Paraná & 0,022 & 0,002 & 0,720 & 0,032 & 3,978 & 3,041 & 0,019 & 1,123 \\
\hline $\begin{array}{c}\text { Santa } \\
\text { Catarina }\end{array}$ & 0,081 & 0,187 & 0,030 & 0,049 & 6,604 & 0,134 & & 1,423 \\
\hline $\begin{array}{c}\text { Rio } \\
\text { Grande do } \\
\text { Sul }\end{array}$ & 0,014 & 0,052 & 0,027 & 0,032 & 9,479 & 0,149 & 0,008 & 0,232 \\
\hline $\begin{array}{c}\text { Mato } \\
\text { Grosso } \\
\text { do Sul }\end{array}$ & 0,177 & - & 0,218 & 0,029 & 2,666 & 4,728 & 0,027 & 1,524 \\
\hline $\begin{array}{c}\text { Mato } \\
\text { Grosso }\end{array}$ & 0,004 & & 0,022 & 0,083 & 2,804 & 4,929 & 0,028 & 2,654 \\
\hline Goiás & 0,043 & 0,112 & - & 0,067 & 1,644 & 7,862 & 0,640 & 0,842 \\
\hline $\begin{array}{l}\text { Distrito } \\
\text { Federal }\end{array}$ & 0,033 & 0,105 & 0,230 & 0,019 & 3,144 & 3,700 & 0,166 & 0,500 \\
\hline
\end{tabular}

O Rio Grande do Sul tem o maior consumo de feijão-preto e um dos menores de feijão-rajado, ficando atrás apenas de Santa Catarina, que também tem um alto índice de consumo de feijão-preto, assim como o Rio de Janeiro. Maranhão e Roraima têm baixo consumo de feijão. Percebemos também grande variedade regional: no Nordeste, por exemplo, estados como Bahia, Sergipe e Alagoas têm baixo consumo de feijão-fradinho e alto de rajado. Em 
compensação, o índice se inverte no Rio Grande do Norte, Piauí e Ceará, este com o maior consumo de um tipo de feijão do país, $15,5 \mathrm{~kg}$. No Pará, lugar conhecido pelo consumo de feijão-manteiguinha, consome, na verdade, feijãorajado. Infelizmente não podemos comparar ao longo da pesquisa as transformações ocorridas nas variedades consumidas em cada local, já que cada divulgação apresenta uma forma de apresentação distinta. Mas podemos perceber a preponderância do consumo de feijão-rajado, ou poderíamos dizer feijão-carioca e uma diversidade regional menor.

Também há a preocupação em apresentar os resultados por renda. $O$ feijão-rajado é o mais consumido no país e tem um índice alto em todas as classes de renda. Porém, o feijão-fradinho apresenta maior consumo na primeira faixa, dos mais pobres, caindo para um pouco mais de um quarto na faixa de maior renda. Na direção oposta está o feijão-jalo, quase o triplo da quantidade é consumida entre os mais ricos. De forma geral, quanto maior a renda, menor é o consumo de feijão.

Tabela 15: Aquisição domiciliar de feijão por classes de rendimento familiar mensal $(\mathrm{R} \$)^{336}$

\begin{tabular}{|c|c|c|c|c|c|c|c|}
\hline & Total & $\begin{array}{l}\text { Até } 400 \\
\text { (1) }\end{array}$ & $\begin{array}{c}\text { Mais de } \\
400 \text { a } 600\end{array}$ & $\begin{array}{c}\text { Mais de } \\
600 \text { a } 1000\end{array}$ & $\begin{array}{c}\text { Mais de } \\
1000 \text { a } 1600\end{array}$ & $\begin{array}{c}\text { Mais de } \\
1600 \text { a } 3 \\
000\end{array}$ & $\begin{array}{l}\text { Mais de } \\
3000\end{array}$ \\
\hline Feijão-fradinho & 1,577 & 3,643 & 2,781 & 1,569 & 0,972 & 0,483 & 0,391 \\
\hline Feijão-jalo & 0,441 & 0,314 & 0,251 & 0,361 & 0,206 & 0,211 & 1,403 \\
\hline Feijão-manteiga & 0,325 & 0,557 & 0,589 & 0,369 & 0,177 & 0,202 & 0,107 \\
\hline Feijão-mulatinho & 0,709 & 1,032 & 0,962 & 0,902 & 0,622 & 0,364 & 0,374 \\
\hline Feijão-preto & 2,891 & 2,777 & 3,095 & 2,916 & 3,092 & 2,893 & 2,538 \\
\hline Feijão-rajado & 5,077 & 4,775 & 5,023 & 5,949 & 5,525 & 4,387 & 4,416 \\
\hline Feijão-roxo & 0,085 & 0,184 & 0,080 & 0,072 & 0,060 & 0,077 & 0,049 \\
\hline Outros feijões & 1,289 & 1,408 & 1,404 & 1,190 & 1,493 & 1,069 & 1,204 \\
\hline
\end{tabular}

Cada sociedade resolve o problema da alimentação de um jeito, como já disse Marshal Shalins ${ }^{337}$. A forma de solucionar uma questão como essa, ou

\footnotetext{
${ }^{336}$ Idem, ibidem.
} 
como a linguagem ou o casamento, é o que distingue uma cultura da outra. A distinção não é apenas uma consequência natural dessas escolhas, ela é desejada. Como modo de afirmação de quem é para a própria sociedade que habita e para a outra. Assim, as formas de alimentação podem dizer muito sobre a sociedade que o faz.

Alguns autores se debruçaram sobre as bases da escolha alimentar. Sabemos que ela é fruto de um sistema que vai além do biológico. Warren Belasco separa-as no tripé responsabilidade, identidade e conveniência. Por responsabilidade ele entende a culpa e o custo. No sentido mais amplo do que preço, o custo que pode ser social, ambiental e político. Identidade, como a influência da sociedade na qual vive e da família e história à qual pertence, quem é a pessoa. E por último, por conveniência, é preciso responder a uma questão: é fácil?338 Assim, na escolha do que comer, esta tríplice influência estaria envolvida. O custo, no caso do feijão, é baixo, não somente no valor monetário, porque este é flutuante, mesmo que seja um dos alimentos mais acessíveis. O custo político e ambiental age no sentido oposto, ou seja, ele é uma escolha quando há um custo político e ambiental de outro alimento, como a carne. Sendo uma fonte vegetal rica em proteína, o feijão é um alimento muito consumido por aqueles que optam, por muitos motivos, a não consumir proteína animal. Já escolha identitária, a segunda categoria de acordo com o autor, é muito visível no consumo de feijão. Carlos Alberto Doria, em seu texto "Feijão como país, região e lar"339, diz que o feijão "esteve presente da dieta dos brasileiros desde os primeiros dias da colonização" 340 e considera como universal na cozinha doméstica brasileira, ao mesmo tempo em que suas variedades apontam um consumo local e pelo modo de preparo um marcador doméstico (domus).

Por último, a categoria conveniência. Jaime Rodrigues relata em seu livro Alimentação, vida material e privacidade que após uma série de conferências no início da década de 40 surgiu a ideia de implementar na cidade

\footnotetext{
337 SAHLINS, Marshall David. Op. Cit. 338 BELASCO, Warren. Op. Cit. p. 30.

339 DORIA, Carlos Alberto Doria. "Feijão como país, região e lar". In: Formação da culinária Brasileira. São Paulo: Três Estrelas, 2014. p. 169-189.

340 Idem, ibidem. p. 171
} 
de São Paulo as feijoarias. Baseados em inquéritos alimentares feitos anos antes, perceberam que o feijão tomava muito tempo para seu preparo ${ }^{341}$.

Essa 'soma de esforços e o dispêndio decorrente do preparo do feijão em cada família' poderia representar uma dificuldade para a ampliação no consumo desse valioso alimento. Por isso, o objetivo do IDORT [Instituto de Organização Racional do Trabalho] era criar 'cozinhas de bairro' destinadas exclusivamente ao preparo de feijão, que seria vendido pronto às famílias - experiência que, segundo o autor, já ocorria nos Estados Unidos.

Era a mesma lógica do pão. Se antes ele era todo preparado em casa, com a mudança dos hábitos alimentares agora ele era comprado pronto, na padaria. Eles pretendiam fazer várias feijoarias nos bairros da cidade, porém apenas uma foi implantada, em 1950, no bairro paulistano do Brás ${ }^{342}$. As feijoarias representam a necessidade de menos tempo no preparo, assim como os feijões semiprontos que surgiram nos supermercados, como nos mostra reportagem da Revista Veja de 12 de outubro de 1997: "Em dez minutos - as prateleiras estão abarrotadas de novidades que poupam tempo na cozinha" ${ }^{343}$. Percebemos que o item conveniência se tornou uma questão fundamental na escolha, principalmente após as mudanças estruturais do âmbito doméstico sobre as quais tratamos no capítulo anterior.

Para outro autor, Alan Warde, essa escolha estaria pautada em três antinomias: praticidade (que pode ser entendida como improvisação) versus planejamento (preferências individuais); restrição (saudabilidade, beleza e economia) versus liberdade (prazer, sabor e extravagância); rotina (tradição) versus variedade (novidade). ${ }^{344}$ Já Luis Câmara Cascudo faz a divisão pela contraposição fome e paladar. Para ele, existem duas bases para 0 comportamento alimentar que estão ligadas, mas que têm pesos diferentes em tempos históricos distintos. Em alguns momentos há a predominância da fome;

${ }^{341}$ RODRIGUES, Jaime. Op. Cit. p. 118.

342 Idem, ibidem. p.120.

${ }^{343}$ FERREIRA, Roger. "Em dez minutos - as prateleiras estão abarrotadas de novidades que poupam tempo na cozinha". Revista Veja. 12 de outubro de 1997, ed 1521. p. 70.

344 WARDE, Alan. Comsuption, food and taste. London: Sage, 1997. Apud: BARBOSA, Lívia. Op. Cit. 
em outros, a do paladar. Quando nos alimentamos tendo em vista o paladar estamos levando em consideração primordialmente o prazer e a bagagem histórica. É este comportamento que Cascudo está interessado quando escreve História da Alimentação no Brasil. Em contraposição, está a fome. A fome não apenas no sentido de ausência, como quando Josué de Castro escreve a Geografia da fome. E também no paradigma que move a decisão. $O$ que se leva principalmente em consideração é a praticidade, a funcionalidade. A alimentação enquanto ato nutricional. Com a tendência de racionalização e industrialização das práticas alimentares, com a diminuição do tempo da refeição, a fome predomina sobre o paladar.

Neste caminho tem a interpretação de Claude Fischler e Estelle Masson em Comer - a alimentação dos franceses, outros europeus e americanos. Para eles, em consonância com Cascudo, "a modernidade aparece assim como uma era de reflexividade implacável, em que perde uma inocência nutricional devido à erosão dos saberes práticos do cotidiano que corroem as 'competências alimentares"' 345 . Neste livro eles fazem uma análise das diferentes formas de comportamento alimentar de franceses, americanos e outros europeus e chegam a duas categorias dentro do debate semelhante à fome e ao paladar: 0 individualismo e a conviviabilidade ${ }^{346}$.

Os americanos seriam a representação do individualismo, preocupados com a nutrição ou com a rapidez, funcionalidade. $\mathrm{Na}$ análise feita através de uma pesquisa de campo, a saúde está muito mais presente no discurso saúde e praticidade. A autonomia do ato de comer constituída principalmente a partir da década de 70, entra no discurso individualista americano. Por outro lado, os franceses estariam na esfera da conviviabilidade, a refeição enquanto momento social de interação, ritual e prazer ${ }^{347}$. Para eles o tempo reservado à refeição e à origem do alimento aparecem como elementos centrais, assim

345 FISCHLER, Claude \& MASSON, Estelle (org) - Comer: a alimentação dos franceses, outros europeus e americanos. São Paulo: Editora Senac São Paulo, 2010. p. 11.

346 Por conviviabilidade eles entendem "as pessoas que participam da criação da vida social, evitando a preservação das sociedades industriais, que procede da servidão do homem à máquina, aos instrumentos, as instituições e às organizações." É um modo fundamental de construir o social, que pode representar o conjunto como a segregação, a hierarquia social. Idem, ibidem. p. 123.

347 Idem, ibidem. p. 49. 
como tradição e regionalismo. Mas os autores concluem: "Será que o modelo francês começou a ceder? Alguns resultados de nossa pesquisa parecem indicar que há uma tendência à erosão realmente existe." ${ }^{348}$ Para justificar essa interpretação, apontam o sentimento de alguns entrevistados: perda do gosto (os alimentos que agora são na maioria vendidos no supermercado não tem o mesmo sabor); desaparecimento da sazonalidade; perda da localidade; desaparecimento do natural. O sentimento de ganho foi de comodidade, constância e variedade. ${ }^{349}$ Os resultados apresentados para o consumo de feijão nestas pesquisas alimentares analisadas também vão em direção parecida. A perda da variedade regional está conjugada com a predominância de variedades que asseguram melhores resultados na plantação. $O$ autoconsumo caiu consideravelmente durante o período, mostrando que 0 supermercado se tora um agente fundamental na intermediação deste alimento. A queda nos números absolutos da quantidade de feijão está atrelada a entrada de outros produtos à mesa, como carne e industrializados.

Nos discursos alimentares do saudável, o feijão já apareceu de ambos os lados. O livro que orienta as futuras esposas diz ${ }^{350}$ :

\begin{abstract}
Ahi está uma coisa, para a qual, na minha opinião, deveria haver uma escola, onde se apprendesse a cosinhar com limpeza (...) Com o curso da escola, o cozinheiro saberia discernir com critério as qualidades e quantidades; teria noções de chimica, que o habilitassem a substituir por outro $o$ pesadissimo, o brutal alimento com que se enche e amortece a população brasileira: o feijão, a carne secca, o cosido dariam logar a coisas mais saudáveis(...)
\end{abstract}

Porém, a maioria dos guias consultados que estão no recorte temporal da pesquisa apontam o feijão como um alimento saudável, como o Guia alimentar para a população brasileira, de $2006^{351}$ :

\footnotetext{
348 Idem, ibidem. p. 136.

349 Idem, ibidem. p. 156-159.

350 ALMEIDA, Júlia Lopes de. O livro das noivas. Rio de Janeiro: Rio de Janeiro: Francisco Alves \& Cia., 1905, p. 95-96.
} 
Muitas vezes supõe-se que a alimentação saudável é muito diferente daquela que as pessoas consomem habitualmente. É verdade que, nas últimas duas décadas, os brasileiros, tanto os que vivem nas cidades como aqueles de áreas rurais, mudaram o seu padrão alimentar, reduzindo o consumo de frutas, legumes e verduras e elevando o de alimentos $e$ bebidas com alto teor de gordura e açúcares elou sal e se distanciaram dos alimentos e refeições tradicionais brasileiros, reconhecidos como saudáveis e saborosos, devendo ser valorizados e difundidos. Um exemplo é o abandono do consumo de uma das preparações mais típicas e comuns a todas as regiões brasileiras: arroz com feijão, combinação nutricionalmente rica e adequada.

$\mathrm{Na}$ última POF, de $2008 / 2009$, os resultados apresentados sobre o consumo de feijão os separa apenas em dois tipos: feijão e feijão verde/corda. Mas incluem um item que não estava nas outras pesquisas, o consumo alimentar extra doméstico. No Brasil, neste período, o consumo de feijão fora do lar é de $12,2 \%$, de feijão verde/corda $6,9 \%$ e das preparações a base de feijão de $15,2 \%$. Esse número é muito menor do que para outros produtos, como a cerveja, com $63,6 \%$, ou a pizza, com $42,6 \%{ }^{352}$. Há também a divisão entre o consumo urbano e rural, mostrando que enquanto a população urbana no Brasil se alimenta de 177,9 gramas diárias de feijão, a rural consome 208,1 gramas. Apesar de na divulgação terem apresentado os feijões sem separá-los em mais variedades, o IBGE criou uma base de dados online, o Sistema IBGE de Recuperação Automática (SIDRA), que disponibiliza os resultados das últimas duas POF para consulta. Lá a forma de apresentação da POF 2002 ainda é mantida, como aparece na tabela:

${ }^{351}$ Brasil. Ministério da Saúde. Secretaria de Atenção à Saúde. Guia alimentar para a população brasileira : promovendo a alimentação saudável / Ministério da Saúde, Secretaria de Atenção à Saúde, . - Brasília : Ministério da Saúde, 2008. p. 33.

352 IBGE. Pesquisa de Orçamentos Familiares 2008/2009. Op. Cit. 
Tabela 16: aquisição domiciliar de feijão - 2008/2009 (kg/ano) ${ }^{353}$

\begin{tabular}{|c|c|c|c|c|c|c|c|c|}
\hline & $\begin{array}{l}\text { Feijão- } \\
\text { fradinho }\end{array}$ & \begin{tabular}{|l|}
$\begin{array}{l}\text { Feijão- } \\
\text { jalo }\end{array}$ \\
\end{tabular} & \begin{tabular}{|l|} 
Feijão- \\
manteiga
\end{tabular} & \begin{tabular}{|l|} 
Feijão- \\
mulatinho
\end{tabular} & $\begin{array}{l}\text { Feijão- } \\
\text { preto }\end{array}$ & $\begin{array}{l}\text { Feijão- } \\
\text { rajado }\end{array}$ & $\begin{array}{l}\text { Feijão- } \\
\text { roxo }\end{array}$ & $\begin{array}{l}\text { Outros- } \\
\text { feijões }\end{array}$ \\
\hline Brasil & 1,174 & 0,143 & 0,252 & 0,552 & 2,011 & 3,905 & 0,032 & 1,052 \\
\hline Norte & 0,687 & 0,698 & 0,21 & 0,116 & 2,35 & 4,665 & 0,035 & 1,292 \\
\hline Rondônia & 0,194 & - & 0,289 & 0,299 & 0,628 & 5,496 & - & 2,324 \\
\hline Acre & 0,216 & & 0,176 & 0,042 & 0,118 & 4,836 & 0,231 & 1,639 \\
\hline Amazonas & 0,164 & 1,194 & 0,058 & 0,084 & 1,266 & 2,691 & 0,054 & 2,808 \\
\hline Roraima & 0,138 & 0,094 & 0,541 & 0,162 & 0,106 & 2,8 & 0,043 & 2,202 \\
\hline Pará & 1,11 & 0,796 & 0,276 & 0,098 & 4,018 & 4,882 & 0,019 & 0,422 \\
\hline Amapá & & 0,051 & 0,286 & & 0,385 & 4,251 & & 2,16 \\
\hline Tocantins & 0,996 & 0,534 & 0,022 & 0,167 & 0,606 & 8,337 & 0,024 & 0,153 \\
\hline Nordeste & 3,832 & 0,137 & 0,56 & 1,614 & 0,533 & 4,178 & 0,044 & 1,395 \\
\hline Maranhão & 1,469 & 0,646 & 1,925 & 1,547 & 0,722 & 1,027 & 0,048 & 1,536 \\
\hline Piauí & 7,647 & 0,534 & 1,893 & 0,689 & 0,472 & 1,396 & 0,193 & 0,791 \\
\hline Ceará & 10,069 & 0,035 & 0,816 & 1,464 & 0,311 & 1,315 & 0,111 & 1,255 \\
\hline $\begin{array}{l}\text { Rio Grande } \\
\text { do Norte }\end{array}$ & 5,759 & 0,154 & 0,801 & 0,459 & 2,012 & 4,798 & 0,062 & 0,257 \\
\hline Paraíba & 3,291 & 0,06 & & 1,615 & 0,43 & 4,996 & 0,018 & 2,773 \\
\hline Pernambuco & 1,81 & 0,021 & 0,048 & 3,242 & 0,76 & 3,406 & 0,01 & 0,64 \\
\hline Alagoas & 1,413 & - & - & 0,964 & 0,193 & 4,498 & 0,009 & 1,958 \\
\hline Sergipe & 0,602 & - & 0,058 & 0,71 & 0,131 & 4,279 & 0,061 & 5,019 \\
\hline Bahia & 2,324 & 0,022 & 0,116 & 1,474 & 0,292 & 7,868 & & 1,257 \\
\hline Sudeste & 0,048 & 0,061 & 0,097 & 0,178 & 2,638 & 4,281 & 0,024 & 0,633 \\
\hline $\begin{array}{l}\text { Minas } \\
\text { Gerais }\end{array}$ & 0,062 & 0,122 & 0,043 & 0,102 & 2,85 & 5,677 & 0,045 & 1,389 \\
\hline $\begin{array}{l}\text { Espírito } \\
\text { Santo }\end{array}$ & 0,025 & 0,239 & 0,073 & 0,037 & 3,973 & 2,694 & 0,064 & 2,045 \\
\hline $\begin{array}{c}\text { Rio de } \\
\text { Janeiro }\end{array}$ & 0,074 & 0,032 & 0,057 & 0,053 & 8,394 & 0,361 & - & 0,09 \\
\hline
\end{tabular}

353 IBGE, Sistema IBGE de Recuperação Automática (SIDRA).Op. Cit. 


\begin{tabular}{|l|r|r|r|r|r|r|r|r|}
\hline São Paulo & 0,033 & 0,028 & 0,141 & 0,276 & 0,207 & 5,241 & 0,02 & 0,353 \\
\hline Sul & 0,024 & 0,137 & 0,213 & 0,033 & 3,606 & 1,334 & 0,02 & 0,781 \\
\hline Paraná & 0,021 & 0,036 & 0,404 & 0,023 & 2,507 & 3,111 & - & 1,337 \\
\hline $\begin{array}{l}\text { Santa } \\
\text { Catarina }\end{array}$ & 0,028 & 0,399 & 0,109 & 0,039 & 2,714 & 0,327 & 0,035 & 0,625 \\
$\begin{array}{l}\text { Rio Grande } \\
\text { do Sul }\end{array}$ & 0,025 & 0,089 & 0,085 & 0,04 & 5,182 & 0,162 & 0,031 & 0,327 \\
\hline $\begin{array}{l}\text { Centro-Oeste } \\
\text { Mato }\end{array}$ & 0,217 & 0,032 & 0,072 & 0,109 & 0,552 & 4,963 & 0,044 & 2,42 \\
\hline $\begin{array}{l}\text { Grosso do Sul } \\
\text { Mato }\end{array}$ & 0,399 & 0,031 & 0,179 & 0,006 & 0,678 & 3,572 & - & 2,424 \\
\hline $\begin{array}{c}\text { Grosso } \\
\text { Goiás }\end{array}$ & 0,158 & 0,009 & 0,075 & 0,075 & 0,506 & 4,498 & - & 2,821 \\
\hline $\begin{array}{c}\text { Distrito } \\
\text { Federal }\end{array}$ & 0,439 & 0,057 & 0,036 & 0,049 & 0,341 & 5,611 & 0,087 & 2,88 \\
\hline
\end{tabular}

Os tipos consumidos em cada região se mantém de maneira geral em relação à última pesquisa, mas podemos perceber uma queda significativa entre elas. Há uma diminuição do consumo de feijões bem característicos na mesa do brasileiro, como o fradinho e o rajado, com quedas expressivas no Ceará e Minas Gerais, respectivamente. O Maranhão, que já tinha um consumo bem abaixo da média, tem uma queda maior. $O$ consumo de feijãopreto no Rio Grande do Sul cai quase pela metade. A pesquisa também aponta fenômenos interessantes, como a introdução do consumo de feijão-preto no Pará e a consequente queda do feijão-rajado. A divisão por renda se mantém, enquanto os mais pobres consomem em média 10,3 kg anuais, para mais ricos, por sua vez, esse número cai para $7,3 \mathrm{~kg}$.

Apesar dos dados apontarem para a diminuição do consumo de feijão, o artigo publicado por Lívia Barbosa ${ }^{354}$ mostra outro resultado. No artigo em questão foi feita uma pesquisa em dez cidades brasileiras com mais de um milhão de habitantes na qual foram entrevistadas pessoas entre 17 e 65 anos pertencentes aos cinco segmentos de renda da sociedade brasileira em 2006. 
Foram estas cidades: Belém, Fortaleza, Recife, Salvador, Brasília, Rio de Janeiro, São Paulo, Belo Horizonte, Curitiba e Porto Alegre. Houve duas etapas: uma qualitativa -com a análise do material de cinquenta grupos focais num total de quatrocentos participantes-e outra quantitativa -um questionário foi aplicado aos responsáveis pela alimentação em dois mil cento e trinta e seis (2136) domicílios escolhidos através de uma probabilística mista. Método semelhante à pesquisa publicada no livro Comer de Claude Fischler e Estelle Masson 355 .

Segundo o estudo, o almoço tem um cardápio homogêneo ${ }^{356}$ :

De toda a amostra, 94\% declararam comer arroz e feijão, acompanhados de algum tipo de carne vermelha (69\%), galinha (42\%), salada (30\%), macarrão (24\%) (...). O consumo de arroz fica acima de $90 \%$ em todos os grupos sociais. 0 mesmo ocorre com o feijão, que só fica abaixo de $90 \%$ entre os segmentos de renda $A$ (85,7\%), em Curitiba (87,5\%) e Belém $(82,6 \%)$.

Lívia conclui que não há tendência à individualização e sim presença de hábitos partilhados pela população brasileira urbana como um todo. Assim, seríamos semelhantes “(...) no que concerne ao conteúdo das refeições e nas atitudes em relação a elas, que transcendem tanto a renda quanto os gêneros, as regiões e as faixas etárias. São indicativos disso as altas porcentagens de ingestão de um mesmo cardápio." Para ela, as refeições com a família estão diminuindo por uma imposição do ritmo de vida, mas há o desejo de comer com a família. "94\% dos entrevistados concordam que a comida é muito importante na vida familiar"357. Para os norte-americanos também. A pesquisa feita por Fischler e Masson concluiu que, apesar da tendência de individualização, liberdade de escolha e higienização, para $44,5 \%$ a refeição ideal deveria ser feita no passado ${ }^{358}$, lugar do alimento compartilhado e junto com a família.

\footnotetext{
355 FISCHLER, Claude e MASSON, Estelle. Op. Cit.

356 BARBOSA, Livia. Op. Cit.

357 Idem, ibidem.

${ }^{358}$ FISCHLER, Claude e MASSON, Estelle. Op. Cit. p. 267.
} 
Barbosa também não concorda com a tese da homogeneização e pasteurização do gosto pelo crescimento do modelo agroindustrial, pois a pesquisa aponta que $90 \%$ dos lares compram a matéria-prima de suas refeições para confeccioná-las em casa. Isso não quer dizer que comprem exclusivamente, pois podem comprar arroz, feijão, iogurte e lasanha congelada. Um produto não excluí o outro. Ela fala que as bases do cardápio brasileiro têm a matéria-prima produzida por pequenos e médios produtores e que a indústria alimentar não domina. $\mathrm{E}$ conclui: "Se temos pasteurização do gosto, certamente é o da tradição, e não o da indústria alimentícia." ${ }^{359}$

Então por qual motivo a Embrapa anuncia ${ }^{360}$ ?

Os trabalhos comprovam, por unanimidade, que há queda do consumo per capita de feijão no Brasil, entretanto, sua magnitude não está bem dimensionada, não havendo consenso sobre as causas. $O$ consumo per capita de feijão ao longo dos últimos 40 anos apresenta uma tendência decrescente da ordem de $1,3 \%$ ao ano, enquanto a população cresceu $2,2 \%$.

O IBGE também aponta a diminuição do consumo de feijão. Para comparar todas as pesquisas, temos de fazer o recorte do consumo de feijão em quilogramas/ano nas regiões metropolitanas. Segundo o IBGE, esse era 14,698 em 1974-1975, passando para 12,134 em 1987-1988, depois 10,189 na seguinte POF, 1995-1996. Em 2002-2003 o consumo diminui para 9,220 e chega em 7,439 na última POF, em 2008-2009. Isso representa uma redução de $49 \%$ do consumo de feijão doméstico ao longo dos quase quarenta anos.

No geral, a diminuição do consumo de feijão entre as duas últimas POF no Brasil inteiro foi de $26,4 \%$. Índice maior do que o encontrado para as regiões metropolitanas, de um pouco menos de $20 \%$. Essa diferença pressupõe uma queda mais expressiva fora dessas grandes cidades. O consumo fora do lar é numericamente pequeno, gira entre $12 \%$ e $15 \%$ como mostramos, então essa não é a maior causa da redução. Essas quedas ao longo do período

\footnotetext{
359 BARBOSA, Lívia. Op. Cit.

${ }^{360}$ Empresa Brasileira de Pesquisa Agropecuária (Embrapa). Disponível em:

http://sistemasdeproducao.cnptia.embrapa.br/FontesHTML/Feijao/CultivodoFeijoeiro/importanci a.htm . Acessado em 30/07/2013.
} 
acompanham a alta de outros alimentos, como os industrializados, carnes e derivados que tiveram uma particular elevação no último período e alimentos à base de farinha de trigo, especialmente o macarrão, que teve um aumento de $60 \%$ entre as duas últimas $\mathrm{POF}^{361}$.

É necessário fazer duas observações sobre a pesquisa publicada por Lívia Barbosa. A primeira é sobre o método. A coleta de dados das POF é feita pelo IBGE a partir de dois mecanismos, entrevista e caderneta de anotação de consumo, o chamado "Bloco de Consumo Alimentar Pessoal"362. Cada família anota sua aquisição durante um período, colocando o alimento e a quantidade.

Essa diferença, da entrevista e da caderneta nos traz alguns indícios sobre as distintas análises. Será que não há uma contradição entre o que é declarado e o que é consumido? Sabemos que as famílias consomem feijão, mas essas pequenas e paulatinas mudanças no cotidiano, da inserção de outros alimentos nas dietas, não são declaradas, às vezes não são nem levadas em consideração. Sabemos que no período proposto o iogurte teve seu consumo mais que dobrado, assim como o refrigerante ${ }^{363}$. Se não são substitutos diretos do feijão, nos mostram, por outro lado, que existem mudanças concretas nas mesas.

Outro ponto é que as práticas alimentares, entre elas o consumo de feijão, é, de modo algum, uniforme nem entre as classes, nem entre as regiões. $\mathrm{Na}$ Região Sul, por exemplo, o consumo de feijão-rajado é menor do que a metade da média nacional segundo a POF de 2008 e na classe A quase inexistente ${ }^{364}$. Relembremos também nossa interpretação sobre os dados da POF de 2002. Ela aponta que a média de consumo anual per capita de feijões ${ }^{365}$ no Brasil é de 12,394 kg. Nos estratos inferiores esse consumo vai para 14,612 kg

\footnotetext{
${ }^{361}$ Consumo de macarrão não-especificado. In: IBGE, Sistema IBGE de Recuperação Automática (SIDRA). Op. Cit.

362 IBGE. Notas Técnicas. Tabela de composição nutricional dos alimentos consumidos no Brasil. Rio de Janeiro, 2004.

363 IBGE. Disponível em: http://www.ibge.gov.br/home/mapa_site/mapa_site.php\#populacao. Acessado em: 14/07/2013.

364 IBGE. Pesquisa de Orçamentos Familiares, 2008/2009. Op. Cit.

365 Para esta consulta somamos os tipos de feijões que a POF optou por apresentar separado são eles: feijão-fradinho, feijão-jalo, feijão-manteiga, feijão-mulatinho, feijão-preto, feijão-rajado, feijão-roxo e outros feijões.
} 
enquanto nas mais altas $10,482 \mathrm{~kg}^{366}$, ou seja, uma queda de $28 \%$. O feijão-jalo acontece o oposto, ele é primordialmente consumido pelas altas classes: enquanto a classe com renda acima de três mil reais $(R \$ 3.000,00)$ consome $1,403 \mathrm{Kg}$, os que ganham menos de quatrocentos reais $(R \$ 400,00)$ consomem $0,314 \mathrm{Kg}$. Carlos Alberto Dória segue na mesma direção: "as variedades rajado, fradinho e preto têm maior consumo nos estratos inferiores, sendo que, nos superiores, temos o rajado, preto e jalo, com participação mínima do fradinho (3\% contra os $24 \%$ nos estratos inferiores)." 367 Desta forma, entendemos que não podemos afirmar um consumo homogêneo pela tradição. Declarar-se brasileiro não se iguala com ter feijão e arroz no prato e nem ingerir o mesmo cardápio.

O que podemos interpretar é que existe um discurso dos entrevistados e que foi assimilado pela pesquisa tendendo ao homogêneo, com traços que estão arraigados à imagem que construímos para o Brasil na mesa, mas que, na verdade, não correspondem à multiplicidade e a inserção do país na lógica do mercado capitalista contemporâneo, de forma mais intensa no meio urbano. Mercado este pautado pela valorização da marca, pela fetichização do produto e pela tendência da individualização das práticas alimentares. A pesquisa não trabalha, porque não se propôs a tal, com o tempo. Quando lidamos com tendências de práticas, entre elas a alimentar, o tempo é fundamental.

A identidade é uma escolha, um filtro, como a memória, uma escolha de fragmentos do passado. Assim como acontece para o discurso identitário, a seleção é fundamental para o processo de formação da memória. "Recordo-me dele (eu não tenho o direito de pronunciar esse verbo sagrado, só um homem na Terra teve esse direito e esse homem morreu)" 368 . Desta forma começa 0 conto escrito por Jorge Luis Borges - Funes, o memorioso que narra a história de um homem que, depois de um acidente, adquire uma capacidade de memorização e percepção antes nunca vistas, infalíveis ${ }^{369}$ :

Sabia as forma das nuvens austrais do amanhecer do dia 30 de abril de 1882 e podia compará-las na lembrança com os

\footnotetext{
366 IBGE. Pesquisa de Orçamentos Familiares 2002/2003. Op. Cit.

367 DÓRIA, Carlos Alberto. "Feijões como patria, locus \& domus no sistema culinário brasileiro"... Op. Cit.

368 BORGES, Jorge Luis. Fiç̧ões. São Paulo, Companhia das Letras, 2007. p. 99.

369 Idem, ibidem. p. 105.
} 
veios de um livro em papel espanhol que ele havia olhado uma única vez (...) Duas ou três vezes tinha reconstruído um dia inteiro; não tinha duvidado nunca, mas cada reconstituição tinha exigido um dia inteiro.

Irineu Funes sabe as horas sem consultar o relógio, reconhecendo o absoluto do tempo; aprende facilmente as línguas, cria sistemas de numeração em que cada signo tem uma palavra e desdenha da generalização da linguagem que nomeia de forma igual coisas completamente diferentes como 0 cão das três horas e quatorze minutos visto de perfil e o cão das três horas e quinze minutos visto de frente. Com o decorrer da narração, o conto vai se tornando aflitivo, há uma sensação de agonia em Funes, ele é incapaz de esquecer, se torna vítima de sua memória, como o próprio diz, "um monte de lixo". Segundo Julio Pimentel, seria um "prisioneiro de sua implacável memória, Funes torna, por um caminho difuso, inútil à própria memória que cultua. Incapaz de escolher e, sobretudo, de esquecer, vive condenado eternamente como sua vida, postada no tempo absoluto - à repetição invariante, a impossibilidade de ser original, livre na escolha e na rejeição" 370 .

Pensamos a formação do discurso identitário como a memória. Esta e a história são formas de narrar o tempo passado, não como opostas, mas como mantidas em relação complexa e dialética. A memória, assim como a história, é sempre seletiva, sua abordagem implica em referir-se a acontecimentos e esquecimentos de sujeitos individuais ou coletivos a partir de interrogações do presente. A relação é conflituosa, mas a barreira entre as duas é mais tênue do que se acreditou o positivismo, por exemplo. Este pregava a possibilidade de uma verdade na história, livre de tendências no presente e no olhar do historiador. Porém, como colocamos, história também é escolha e quem a faz só pode fazê-la baseado em seu cabedal de conhecimento e experiências do presente. As visões do passado são construções justamente pelo fato de que 0 tempo passado não pode ser eliminado e estas são projetadas no presente ${ }^{371}$.

\footnotetext{
370 PINTO, Julio Pimentel. Memória do mundo - ficção, memória e historia em Jorge Luis Borges. São Paulo: Estação Liberdade, 1998. p. 315.

371 SARLO, Beatriz. Tempo Passado - cultura da memória e guinada subjetiva. São Paulo, Companhia das Letras, 2007. p. 12.
} 
Fala-se do passado sem suspender o presente e, muitas vezes, implicando também o futuro. Lembra-se, narra-se ou se remete ao passado por um tipo de relato, de personagens, de relação entre suas ações voluntárias e involuntárias, abertas e secretas, definidas por objetivos ou inconscientes (...) Introduzem um tom dominante nas 'visões de passado'.

Por isso, uma visão de passado que represente o todo não é possível, não é capaz narrar o tempo sem cortes ou de forma global. Nesse âmbito, memória e história caminham paralelas na sua incapacidade totalizante e imparcial, no seu aspecto subjetivo. Divergem, segundo Beatriz Sarlo, pelo método da história, que supervisiona os modos de reconstituição do passado, a investida do passado regulada pelo ofício, mesmo que por funções do presente $^{372}$. Assim, a construção de uma representação social, como a identidade nacional, semelhante à construção da memória, não passa pelo rigor dos métodos históricos, mesmo que os resultados das análises históricas sirvam para fins identitários.

Críticas feitas à identidade e à memória tratam de seus excessos e de sua introdução no campo da história, no qual seus projetos e suas visões são nitidamente percebidos, muitas vezes pela matéria frágil da forma testemunhal, pela vivência que a memória carrega, não se tenta o distanciamento pretendido pela história. Não acreditamos em uma história totalmente engajada, mas pensamos a construção do historiador, como já foi dito, como resultado de seu campo de experiência. Basta olharmos para pensadores como Sartre ou Walter Benjamin que foram nitidamente influenciados por seus espaços de ação, pelo contexto no qual produziram suas obras. Com a crise da ciência e a percepção da incapacidade da total imparcialidade de quem produz, uma nova corrente historiográfica surge para pensar os limites deste campo de estudo, limites estes que é preciso ter consciência no momento em que se narra o passado.

Hobsbawm discorre sobre o assunto no texto "Não basta a história de identidade". O que difere a construção do passado para um fim identitário da análise histórica é a seleção prévia daquilo que é bom para a causa, para o

\footnotetext{
372 Idem, ibidem. p13-15.
} 
país e muitas vezes o anacronismo, descontextualização e omissão daquilo que não serve. Neste sentido, se aproxima do processo de memória, que elege os fatos. Porém, muitas vezes, o historiador acaba por reunir elementos que serão usados para a formação dessa identidade e, nesse sentido, não há como dissociar o nosso trabalho da política contemporânea.

O rádio e a televisão, assim como outros meios da imprensa, têm uma fundamental importância na formação da ideia de unidade nacional, tornando palpável dimensões que não seriam visíveis sem a construção desses veículos. Eles espalham pelo território nacional a mesma imagem, aparentemente fazendo diminuir as diferenças. Benedict Anderson, em seu livro Comunidades Imaginadas, trata sobre o tema quando liga o sentimento de pertencimento ao surgimento da imprensa escrita e das línguas nacionais, que sobrepõe as diferenças dentro do território ${ }^{373}$. A construção de um ritual partilhado é fundamental para esse processo, como o hábito de assistir televisão no Brasil durante o período da pesquisa, como as telenovelas. Como um movimento que se retroalimenta, esses meios discursam sobre uma realidade de comportamento ao mesmo tempo que reforçam ou induz comportamentos. Além disso, a televisão é um dos meios nos quais se dissemina a propaganda e direciona o consumo que também forma bases para o discurso sobre identidade nacional. Em 1970 apenas $24,11 \%$ das casas tinham televisão. ${ }^{374}$ Esse número sobe para 56,1\% em 1980 e segundo dados do IBGE, o número de domicílios com televisão chega a 71\% nos anos 90 e 87,9\% em 2000.

Porém, para autores como Appadurai, no mundo contemporâneo há um corte com qualquer tipo de passado ${ }^{375}$. O passado se torna mais um discurso vigente entre tantos outros, assim como acontece com a prática alimentar. $O$ que para Benedict Anderson teria ajudado ao sentimento de pertencimento nacional, quando exacerbado, acaba por desvincular o sujeito do seu território, pois agora ele não se limita ao Estado-nação. Em outras palavras, a comunicação eletrônica aumenta o campo e oferece mundos imaginados

\footnotetext{
${ }^{373}$ ANDERSON, Benedict. Op. Cit.

374 HAMBURGER, Esther. "Diluindo fronteiras: a televisão e as novelas no cotidiano". In: NOVAIS, Fernando, História da vida privada no Brasil - contrastes da intimidade contemporânea. São Paulo: Companhia das Letras, 1998. p. 449.

375 APPADURAI, Arjun. Dimensões culturais da globalização. Lisboa: Teorema, 2004. p. 13.
} 
novos, mais vastos, fazendo com que o nacional de dissipe. As migrações, deslocamentos, trocas de imagens, textos e sensações cada vez mais rápidos causam "uma nova ordem de instabilidade na moderna produção de subjetividades" ${ }^{376}$. Se formam grupos que muitas vezes são transnacionais, funcionam e se deslocam além dos limites da nação.

A necessidade da diferença serve para identificar e separar um grupo do outro. O feijão é, assim, um desses signos que caracterizam a diferença quando adotamos o discurso nacional. "Sugiro, portanto, que a cultura é a dimensão penetrante do discurso humano que explora a diferença para gerar diversas concepções de identidade de grupo." $377 \mathrm{O}$ conjunto das diferenças que não são estáticas, se modificam constantemente e são apenas um espectro do sistema de manifestações culturais de um grupo. Como o hábito de comer feijão-carioca, hoje o mais difundido no país, iniciou no final da década de $70 \mathrm{e}$ nem consta na primeira pesquisa analisada, o ENDEF. Esses hábitos aparecem para legitimar grupo como naturais e enraizados ao longo da história. Qualquer recorte está sujeito a esta dinâmica, "a própria localidade é um produto histórico e que as histórias que permitam a emergência de localidades acabam por ficar sujeitas à dinâmica do global" ${ }^{378}$.

Qualquer história contada com um fim identitário passa por esse processo, tanto a nacional quanto a local. O que se precisa ter em mente é que elas estão a cargo da construção da unidade, e não propriamente do fornecimento de dados históricos factíveis. Elas podem e devem ser objeto de análise dos historiadores e pesquisadores. Porém, alguns discursos fazem mais sentido em determinado tempo do que outros. $O$ discurso nacional não tem a capacidade de abarcar a relação do local com a complexidade das conexões globais dos últimos quarenta anos. Como foi mostrado, ela teve uma função no Brasil no final do século XIX e principalmente na primeira metade do século XX que foi legitimar o Estado centralizado.

O que perpassa muito da discussão sobre globalização e os aspectos culturais é a homogeneização destes em contraposição com a singularidade.

\footnotetext{
376 Idem, ibidem, p. 16.

377 Idem, ibidem. p. 27.

378 Idem, ibidem. p. 33.
} 
Termos como americanização e "mcdonaldização" tendem a encarar o processo de trocas e influencias como a padronização dos costumes. Muitas vezes, no entanto, quando o local é influenciado por novas tendências, elas logo são modificadas e incorporadas e passam a fazer parte daquele lugar. Globalização não significa necessariamente homogeneização, mas muitas vezes usam-se instrumentos deste, como técnicas publicitárias, hegemonias linguísticas e determinados tipos de comportamento. Mas essas estratégias chegam de forma diferente em cada local. "Portanto, a principal característica da política global de hoje é a política do mútuo esforço da semelhança e da diferença que se canibalizam reciprocamente, assim proclamando o saque vitorioso das ideias gêmeas do lluminismo, o universal triunfalista e o particular resiliente." ${ }^{379} \mathrm{~A}$ invenção da tradição para servir a uma identidade se torna mais difícil nesse lugar, com tantas informações, embates e fluidez da comunicação.

Em uma época marcada pela valorização da diferença, a questão da identidade pode parecer um desafio. A tradição não se opõe a transformação. Como disse Massimo Montanari, a tradição é uma inovação que deu certo ${ }^{380}$. A tradição é dinâmica e mutável, complexa e heterogênea. $O$ discurso da unificação cabe a um ideal nacionalista datado e com um objetivo. "As nações são entidades historicamente novas fingindo terem existido durante muito tempo"381.

Se por um lado há a necessidade da criação de uma identificação individual para a diferenciação no grupo, há também o desejo do eu coletivo, que não está determinado a limites geográficos. O homem não existe sozinho, mas ele pode se juntar a grupos com as mais diferentes identificações. Pode ser um grupo local, por afinidades musicais, políticas e também alimentar. A acefalia citada no terceiro capítulo trouxe inúmeros outros parâmetros para o comportamento alimentar que se tornam também formas de identificação, inclusive de grupos pautados na tradição. "A cultura vai sendo menos o que Pierre Bourdieu chamaria um hábito (um domínio tácito de práticas e disposições reprodutíveis) e mais uma arena de escolha, justificação e

\footnotetext{
379 Idem, ibidem. p. 63.

380 MONTANARI, Massimo. Comida como cultura. Op. Cit. p. 183.

381 HOBSBAWM, Eric. Sobre História. Op. Cit. p. 285.
} 
representação consciente, esta última muitas vezes para públicos especialmente deslocados." ${ }^{382}$

Uma briga entre a singularidade desconectada e a unidade globalizante, que pouco respeita as diferenças ${ }^{383}$. "O paradoxo central da política étnica no mundo atual é que os fatores primordiais se globalizaram. Ou seja, os sentimentos, cuja maior força está na sua capacidade de fazer da intimidade um estado político e da localidade um palco para a identidade, vão se espalhando por espaços vastos e irregulares à medida que os grupos se deslocam, mas mantendo-se ligados entre si através de sofisticados processos de comunicação" ${ }^{384}$. Muitas vezes os discursos de resgate surgidos a partir da tradição pregam a manutenção daquela manifestação cultural como se ela fosse capaz de estar presente fora da época que estava inserida, com seus propósitos e objetivos intrínsecos. Em vez disso, podemos fazer um debate sobre seu conteúdo histórico e uma análise crítica da formação daquela determinada cultura alimentar, processo distinto do resgate da tradição. Este se torna discurso anacrônico. A busca pelas práticas deslocadas do seu tempo histórico podem parecer sem sentido ou função.

O alimento, antes de ser consumido, passa por diferentes transformações do seu papel. Primeiro ele é selecionado como alimento, isso já o difere de outros que não são consumidos, não são identificados como alimentos, mesmo que sejam comestíveis. Ele é plantado e colhido, transformado por técnicas culinárias que podem diferir de região para região. Diversas também são as formas do comer, dos utensílios usados e das formas de comportamento à mesa. É o percurso do alimento para o seu valor simbólico. "O preparo do alimento marca um momento cultural central da passagem da natureza à cultura"385. Não há como fazer uma antítese de tradição e transformação social. Como mecanismo dinâmico, a tradição se move através do tempo e transforma, ela muda.

\footnotetext{
382 APPADURAI, Arjun. Op. Cit.p. 66.

383 LEVI-STRAUSS, Claude (org.). La identidad. Madrid: Ediciones Petrel, 1981. p. 13.

${ }^{384}$ APPADURAI, Arjun. Op. Cit. p. 56.

385 ROSSI, Paolo. Comer: necessidade, desejo, obsessão. São Paulo: Editora Unesp, 2004. p. 32.
} 
Desta forma, o crescimento de produtos industrializados na refeição é paulatino e lento e de modo algum rígida e um dado terminado. Ela é uma tendência durante o período pesquisado, que, apesar de compartilhar com as permanências das tradições o espaço da refeição, cada dia parece estar ganhando um lugar maior. Se "o consumo de refrigerantes tornou-se, a partir de 1986, nos Estados Unidos, maior do que o consumo de água encanada ou engarrafada," ${ }^{386}$ o Brasil estaria imune a isso?

Assim é o feijão. Por mais que tenhamos encontrado registros desde o século XVII, podemos perceber que não é de modo algum homogêneo $e$ estático. A começar pela confusão léxica e botânica, a imensa variedade e as concentrações regionais apresentadas pelas pesquisas alimentares. Vejamos por exemplo o caso do feijão-carioca. Se no final do período da pesquisa ele é o mais importante para o consumo nacional, representando, segundo a Embrapa $^{387}, 70 \%$ do total, este não era no período inicial. Ele nem existia. Concluímos que o feijão, mesmo com a queda mostrada ao longo do capítulo, continua presente na mesa do brasileiro, junto com outros alimentos com papel mais expressivo, como o arroz, pão, carnes e leite. Mas o feijão, diferentemente dos outros, adquire um papel simbólico fundamental: dono das tradições.

386 STEINGARTEN, Jeffrey. O homem que comeu de tudo. São Paulo: Companhia das Letras, 2000. p. 66.

387 FARIA, Luis Caudio de. et. al. "BRS Requinte: nova cultivar de feijoeiro comum, de tipo de grão carioca, com retardamento do escurecimento do grão". Embrapa, 2000. 


\section{Considerações Finais}

O imbróglio com o nome feijão pode trazer dificuldades para sua definição. Como vimos, ele já era usado há muito tempo na Europa, antes de seus habitantes virem colonizar as terras americanas e encontrarem uma espécie nativa com características semelhantes às que eram usadas por lá. Dessa forma, o feijão, tal como entendemos hoje, no Brasil refere-se principalmente a dois gêneros: Phaseolus e Vigna. Mas a definição com o nome botânico não passa nem perto de resolver a questão. Primeiro porque há algumas exceções, como o Cajanus Cajan, do feijão-guandu, e depois porque esses gêneros englobam algumas espécies e muitas variedades. Soma-se a isso o fato de o nome vulgar mudar de região para região, podendo o mesmo termo compreender variedades diferentes. Nem o IBGE conseguiu resolvê-la. Mesmo com as listas citadas e alguma tentativa de sistematização, o instituto coloca sob o mesmo nome, feijão-rajado, duas variedades bem diferentes, sendo o próprio feijão-rajado e o feijão-carioca.

Porém, sabemos que o feijão pode estar em uma mesa em Manaus ou nas serras gaúchas acompanhado de arroz e alguma carne, ou de farinha de mandioca, se for em alguma casa do Nordeste ou do Norte. Luís da Câmara Cascudo diz que "para o povo uma refeição sem feijão é um simples ato de enganar a fome. Não de alimentar-se. Não há refeição sem feijão"388. Ele esteve presente na mesa do brasileiro desde os tempos coloniais e principalmente nos discursos adotados sobre a cozinha nacional. Nos relatos de viajantes, há diversas passagens em que esse alimento aparece como corriqueiro à mesa. "Abrigadas em barracas, negras vendem café e carne-seca com feijão, prato habitual de gente pobre e frequentemente das classes mais finas" ${ }^{389}$. Apesar de os indícios e os estudos historiográficos recentes apontarem que o feijão se tornou amplamente difundido apenas no final do

\footnotetext{
388 CASCUDO, Luis da Câmara. Historia ... Op. Cit. p. 213.

389 BIARD, François. Dois anos no Brasil (1858-1859). Rio de Janeiro, Imprensa Nacional, 1945. p. 43.
} 
século XVIII e no século $X I X^{390}$, ele não deixa de figurar como alimento essencial da representação da mesa do brasileiro.

A discussão modernista foi expoente nesse retrato. Era preciso se diferenciar dos europeus, o que antes era para ser escondido se tornou elemento para construir a imagem do Brasil. Nesse movimento, que entendemos de forma ampla, estavam envolvidas diversas áreas, como artes plásticas, literatura e estudos acadêmicos. Destacamos aqui aqueles personagens que foram expoentes para essa construção do alimento na mesa brasileira, claro que não sozinhos. Entre eles, Luis da Câmara Cascudo, folclorista e introdutor da antropologia histórica no país, escreveu a grande obra que olha os hábitos alimentares da população, História da Alimentação no Brasil. Cascudo tinha uma amizade conhecida com Mário de Andrade, que dizia: "um dos meus cuidados foi tirar a geografia do livro. Misturei completamente o Brasil inteirinho como tem sido minha preocupação desde que intentei me abrasileirar e trabalhar o material brasileiro." 391 Essa era a proposta de parte das obras surgidas nesse contexto, a apreensão de um país único, criado no tripé do índio, negro e branco.

Outro expoente das Ciências Humanas foi Gilberto Freyre, com grandes obras como Casa Grande e Senzala e Açúcar. Porém, é no Manifesto Regionalista que ele nos mostra sua ideia sobre cozinha no Brasil, exaltando as cozinhas regionais, principalmente a nordestina. Da mesma forma faz Monteiro Lobato, considerado pré-modernista, que retrata a vida no Vale do Paraíba e o caipira, além de esbravejar contra o francesismo em seus escritos. Nesse ponto, todos são iguais.

Enfim, somado a eles outros atores desse contexto, temos um momento fundamental para a consolidação da imagem brasileira. A alimentação é central para esse entendimento, como a ligação entre o passado e detentor da tradição. $O$ feijão, alimento que estava presente nas mesas, principalmente as menos abastadas, foi um elemento importante nessa construção. Se não sabemos ao certo quando ele se tornou um alimento primordial, temos como confirmar que na primeira metade do século XX ele já era majoritário.

\footnotetext{
390 PAPAVERO, Claude. "Dos feijões à feijoada: a transformação de um gênero comestível pouco apreciado em mantimento básico brasileiro". Op. Cit. p. 155.

391 Idem, ibidem. p. 11.
} 
Porém não único. As pesquisas alimentares analisadas ao longo do trabalho mostram a complexidade do sistema alimentar no período proposto (1973-2009). O IBGE, órgão responsável por ela, surge e se consolida como mais um mecanismo para entender e retratar o Brasil, no contexto do Estado Novo. A compreensão passa pela alimentação de seus habitantes e a forma de consumo. Assim começamos nossa análise pelo ENDEF, que foi a primeira grande pesquisa, minuciosa, com tantos detalhes apreendidos que não foi amplamente divulgada. Não por falta de vontade do órgão, porque ela foi encomendada para entender como come o Brasil, esta foi barrada porque grande parte da população passava fome e a possibilidade de o pesquisador anotar alguns comentários fez com que chegasse até nós informações estarrecedoras, como crianças que brigam para comer as próprias fezes ${ }^{392}$. E esses relatos não interessavam à propaganda do milagre econômico. Apesar disso, a alimentação se mostra diversa, com arroz e açúcar como os alimentos mais consumidos nacionalmente.

Os feijões, segundo Maurício Teixeira Vasconcellos ${ }^{393}$, nos mostra as preferências regionais, como o feijão-preto no Rio de Janeiro, feijão-de-corda em algumas regiões do nordeste e o rosinha em São Paulo. A tentativa de sistematização dos nomes citados na pesquisa nos revela uma imensa variedade, se não de variedades botânicas, pelo menos na nomenclatura. Trezentos e noventa e cinco nomes nos mostram que a década de setenta ainda não apresentava uma distribuição nacional de alimentos, uma política unificada e que imperava consumos a partir de referências locais.

A primeira pesquisa não traz uma menção ao feijão-carioca, tão presente no período final. Nem poderia. Essa é uma variedade surgida em meados da década de setenta a partir de uma mutação em São Paulo que tinha uma produtividade que as vezes chegava ao dobro das outras. Ele começou a configurar nas pesquisas seguintes e se tornou fundamental para 0 consumo de feijão no Brasil, tornando-se o principal tipo no contexto final, em 2008/2009.

O dobro da produtividade provavelmente foi um fator importante para que o feijão-carioca se espalhasse. Como mostramos brevemente no segundo

${ }^{393}$ VASCONCELLOS, Maurício Teixeira Leite de. Op. Cit. p. 06. 
capítulo, a pouca atenção governamental aos pequenos produtores, responsáveis pela maioria do plantio de feijão, faz com que ocorram variações constantes na produção. Com dificuldades de aceitação no mercado, podemos aferir que um grão mais produtivo traz mais segurança para uma colheita sem tecnologia empregada e de baixa produtividade. Essa falta de política pública e os problemas desta agricultura fez com que o Brasil importasse feijão em todo o período analisado, mesmo que em quantidades bem pequenas em alguns anos. Os dados da FAO também mostraram que o Brasil, durante esse espaço de tempo, não é o principal produtor deste gênero no mundo, ficando atrás da Índia. Da mesma forma não tem o maior consumo per capita, esse posto pertence a alguns países africanos, como Quênia e Ruanda, que têm consumo médio de $50 \mathrm{~kg}$ por ano.

As pesquisas analisadas variaram conforme os anos, mesmo que tenham os dados comparados entre si. A maior discrepância vem da primeira, - ENDEF, para as POF seguintes. Aquela pretendia analisar o consumo alimentar, pesando cada refeição e a sobra para medir a ingestão nutricional, enquanto as outras que seguiram se preocuparam com a aquisição, ou seja, a compra de alimentos e outros elementos domésticos. Ainda assim, mesmo que abordados de forma diferente, todas elas medem o consumo doméstico alimentar, nosso tema de interesse.

As POF seguintes demonstram, de forma geral, uma queda paulatina tanto da quantidade do feijão consumido, chegando a $49 \%$, quanto da variedade. A pesquisa de 2002/2003 enumera, mais uma vez, os nomes de feijões citados e esse número cai para cento e cinquenta e dois, menos da metade dos mencionados no ENDEF, e uma queda de 40\%. Em compensação, alguns itens ganham mais espaço na mesa do brasileiro, como os alimentos industrializados, com uma alta acumulada de 400\% (cerveja, refrigerantes, carnes bovinas e frango). O leite e o arroz polido mantêm um papel protagonista durante todo o período. Percebemos um fenômeno interessante: entre as duas últimas POF, a queda do consumo de feijão foi maior no meio rural que no urbano. Atribuímos a isso o pequeno aumento de renda das classes mais baixas, que, para fugir de alimentos com estigmas sociais, como o feijão, o substituem por outros, como carne e macarrão. 
O que a economia chama de elasticidade de demanda negativa, o fato de um alimento ser menos consumido quanto maior é sua renda, se confirma ao longo de toda a pesquisa. O feijão (e no sentido mais amplo, as leguminosas) carrega o estigma de alimento de pobre, daquele que não pode comer carne e tem na leguminosa sua fonte de proteína. Esta imagem perpassa o mais diverso espaço e tempo, indo dos poemas do século XVI às últimas estatísticas. Porém, temos algumas exceções, como o feijão-jalo, consumido nas classes mais abastadas.

Mesmo assim, o feijão continua figurando entre os alimentos tidos como tradicionais e necessários para a alimentação do brasileiro, a refeição perfeita, como mostra esse guia alimentar de 2006394: "A preparação típica brasileira feijão com arroz é uma combinação alimentar saudável e completa em proteínas". Porém, em um sistema capitalista em que todos os elementos são mercadorias, o feijão, sem campanhas milionárias como a dos refrigerantes ou a das carnes, fica na periferia do sistema comercial. Ao contrário destes, ele é o sinal da pobreza. Portanto, perdeu paulatinamente espaço na mesa brasileira e a diversidade antes consumida.

Pudemos perceber ao longo desta pesquisa que, de modo algum, esse consumo é homogêneo no tempo ou espaço, ou seja, ao longo do período proposto e no imenso território brasileiro. Ele se torna homogêneo, contudo, no discurso. As categorias pensadas por Woortmann ${ }^{395}$ que diferenciam o consumo idealizado do consumo efetivo são úteis para pensar essa questão. Não há uma distância entre o discurso sobre o feijão no Brasil e o efetivo consumo, quando há o consumo de feijão, este acontece porque para o comensal aquele alimento tem um significado. Porém, o discurso recorta alguns elementos que os servem, diminuindo sua complexidade, como fazemos com a memória. Ele esquece outros alimentos que são ainda mais expressivos quantitativamente na mesa do brasileiro, como o leite e o arroz.

Tais discursos estão a cargo da manutenção da unidade, da figura consolidada e da tradição, que entra como argumento central nele, como algo permanente e uniforme. A questão central não é a perda da tradição e sim sua

\footnotetext{
${ }^{394}$ Brasil. Ministério da Saúde. Secretaria de Atenção à Saúde. Guia alimentar para a população brasileira Op. Cit. p. 61.

${ }^{395}$ WOORTMANN, Klass, Op. Cit.
} 
transformação. Porque elas não são opostas, a tradição vive em transformação. O feijão-carioca nos mostra que os costumes se movem, e se movem cada vez mais rápido, tornando-se, em trinta anos, um prato tradicional. Resta-nos analisar criticamente o contexto maior, não o da "perda" da tradição, e sim o da simplificação do conhecimento dos produtos que fazem parte do cotidiano doméstico, entre eles, o alimento. Simplificação esta causada por muitos fatores, entre eles a rede comercial que toma as cidades e impede a visualização da cadeia, a diminuição da variedade ofertada e as grandes campanhas publicitárias que introduzem apenas uma forma de fazer um preparo, como o leite condensado. Tanto a diminuição do consumo quanto o afunilamento da diversidade fazem parte do mesmo fenômeno maior - a dominância do mercado capitalista sobre a alimentação. Com a tradição em movimento, esse novo espectro que se lança no período final da pesquisa nada mais é do que o fruto desta sociedade que a alimenta. 


\section{Bibliografia e Fontes}

\section{Fontes}

ALMEIDA, Júlia Lopes de. O livro das noivas. Rio de Janeiro: Rio de Janeiro: Francisco Alves \& Cia., 1905,

ANDRADE, Carlos Drummond de. Amar se aprende amando. Rio de Janeiro: J. Olympio, 1985.

ANDRADE, Mário de. Aspectos da literatura brasileira. Belo Horizonte: Editora Itatiaia, 2002.

ANDRADE, Mário. Pauliceia desvairada. São Paulo: EDUSP, 2003.

Macunaíma: o herói sem nenhum caráter. São Paulo: Agir Editora, 2008.

ANDRADE, Oswald de. Pau Brasil. Paris: Sans Pareil, 1925.

BATES, Henry Walter. O Naturalista no Rio Amazonas (1848-1859). vol. I, São Paulo, Companhia Editora Nacional, 1944.

Brasil. Ministério da Saúde. Secretaria de Atenção à Saúde. Guia alimentar para a população brasileira : promovendo a alimentação saudável / Ministério da Saúde, Secretaria de Atenção à Saúde, . - Brasília : Ministério da Saúde, 2008.

BIARD, François. Dois anos no Brasil (1858-1859). Rio de Janeiro, Imprensa Nacional, 1945.

BUARQUE, Chico. Construção. CD. Rio de Janeiro: Philips, 1971.

CANSTATT, Oscar. Brasil, a Terra e a Gente (1868). Rio de Janeiro, Irmãos Pengetti Editores, 1954. 
CASCUDO, Luis Câmara. História da Alimentação no Brasil. São Paulo: Global, 2011.

Antologia do Folclore Brasileiro. São Paulo: Global, 2001.

DAVATZ, Thomas. Memórias de um Colono no Brasil (1850). São Paulo, EDUSP/ Biblioteca Histórica Brasileira/ Martins Editora, 1972.

D'ORBIGNY, Alcides. Viagem Pitoresca Através do Brasil. São Paulo, Belo Horizonte, EDUSP/ Itatiaia Editora, 1976.

FREYRE, Gilberto. Manifesto regionalista. Comentário: Antônio Dimas (USP). Disponível on-line em http://www.ufrgs.br/cdrom/freyre/freyre.pdf. Acesso dia 15.07.2013.

. Casa Grande e Senzala. São Paulo: Global, 2006.

LOBATO, Monteiro. Ideias de Jeca Tatu. São Paulo: Globo, 2008.

. Histórias de Tia Nastácia e O Pica-pau Amarelo. São Paulo: Círculo do Livro, 1986.

. "Paranóia ou mistificação: a propósito da exposição Malfatti". O Estado de São Paulo. 20 de dezembro de 1917.

NIEUHOF, Johann. Memorável Viagem Marítima e Terrestre ao Brasil (16401649). São Paulo, Martins Editora, 1942.

SOUSA, Gabriel Soares de. Tratado Descritivo do Brasil (1587). São Paulo, EDUSP/ Companhia Editorial Nacional, 1971.

VILHENA, Luiz dos Santos. Cartas de Vilhena. Notícias Soteropolitanas e Brasílicas (1802). vol. I, Salvador, Imprensa Oficial da Bahia, 1922.

\section{Base de dados}


Companhia Nacional de Abastecimento (CONAB). Disponível em: http://www.conab.gov.br/ Acessado 15.08.2014.

Companhia Nacional de Abastecimento (CONAB). Séries Históricas. Disponível em:

http://www.conab.gov.br/conteudos.php?a=1252\&t=2\&Pagina_objcmsco nteudos=2\#A_objcmsconteudos Acessado 08.11.2014.

Empresa Brasileira de Pesquisa Agropecuária (Embrapa). Disponível em: http://www.embrapa.br/\# Acessado em: 30.07.2013.

Instituto de Economia Agrícola Disponível em: http://ciagri.iea.sp.gov.br/nia1/precos_medios.aspx?cod_sis=4 acessado 05.10.2014.

Organização das Nações Unidas para Alimentação e Agricultura (FAO). Disponível em http://faostat.fao.org/site/354/default.aspx . Acessado 17.09.2014.

\section{Instituto Brasileiro de Geografia e Estatística (IBGE)}

Censo Agropecuário, 2006. Rio de Janeiro, 2007.

Censo Agropecuário, 2006. Agricultura familiar: Primeiros resultados. Rio de Janeiro: 2007, p. 39.

Códigos de alimentos do ENDEF. Rio de Janeiro, 1974.

ENDEF - Dados Preliminares. Consumo Alimentar - Antropometria. Região I e Região III. Rio de Janeiro, 1977.

ENDEF - Dados Preliminares. Consumo Alimentar - Antropometria. Região V. Rio de Janeiro, 1977. 
ENDEF - Dados Preliminares. Consumo Alimentar - Antropometria. Região II e Região IV. Rio de Janeiro, 1977.

ENDEF - Dados Preliminares. Consumo Alimentar - Antropometria. Região VI e Região VII. Rio de Janeiro, 1977.

Estudo Nacional de Despesa Familiar - Tabela de composição de alimentos. 5 edição, Rio de Janeiro, 1999.

Estudo Nacional de Despesa Familiar - Manual de Instruções. Rio de Janeiro, 1974.

Estudo Nacional de Despesa Familiar - Dados Preliminares. Rio de Janeiro, 1977.

Manual do agente de pesquisa. Rio de Janeiro, 2002.

Memória - Sínteses históricas e linha do tempo. 2014. Disponível em: http://memoria.ibge.gov.br/sinteses-historicas/linha-do-tempo acessado em 06/01/2014.

Nomenclatura dos alimentos consumidos no Brasil - Parte 1 - vegetais. Rio de Janeiro,1980.

Nota Técnica. Rio de Janeiro, 2008.

Notas Técnicas. Tabela de composição nutricional dos alimentos consumidos no Brasil. Rio de Janeiro, 2004.

Pesquisa de Orçamentos Familiares 1987/1988. Rio de Janeiro, 1991.

Pesquisa de Orçamentos Familiares 1995/1996. Rio de Janeiro: IBGE, 1997.

Pesquisa de Orçamentos Familiares 2002/2003. Rio de Janeiro, 2004.

Pesquisa de Orçamentos Familiares 2002/2003 - Análise da disponibilidade domiciliar de alimentos e do estado nutricional no Brasil. Rio de Janeiro: IBGE, 2004

Pesquisa de Orçamentos Familiares, 2008/2009. Rio de Janeiro, 2010. 
Pesquisa de Orçamentos Familiares 2008-2009. Manual do Agente de Pesquisa. Rio de Janeiro, 2008.

Sistema IBGE de Recuperação Automática (SIDRA). Disponível em: http://www.sidra.ibge.gov.br/ acessado em 2014.

\section{Periódicos}

Jornal Folha de São Paulo

Jornal O Estado de São Paulo

Revista Isto É

Revista Veja

LESSA, R. "Retrato proibido da fome". São Paulo: Gazeta Mercantil S.A., ano 9, n. $458,02 / 10 / 85$

Revista Brasileira de Geografia, n. 2 ano II, abril 1940.

G1 - Portal de notícias da Globo. Disponível em: http://g1.globo.com/index.html acessado em 10.05.2014.

\section{Bibliografia}

ALBALA, Ken. Beans, a History. Oxford, New York: Berg, 2007.

ALGRANTI, Leila Mezan. "História e cultura da alimentação na América Portuguesa - tradição e mudanças (uma análise historiográfica)". I Colóquio de história e cultura da alimentação: saber e sabor - história, comida, identidade, Universidade Federal do Paraná, agosto de 2007. 
ALMEIDA, Maria Hermínia Tavares de \& WEIS, Luiz. "Carro-zero e pau-dearara: o cotidiano da oposição de classe média ao regime militar". In: NOVAIS, Fernando (org). Historia da vida provada no Brasil - contrastes da intimidade contemporânea. Vol 04. São Paulo, Companhia das Letras, 1998.

ANDERSON, Benedict. Comunidades imaginadas. Reflexões sobre a Origem e a Expansão do Nacionalismo. Lisboa: Edições 70, 2005.

APPADURAI, Arjun. Dimensões culturais da globalização. Lisboa: Teorema, 2004.

ARNAIZ, Mabel Gracia. Paradojas de la alimentación contemporánea. Barcelona: Icaria, 1996.

ARRIGHI, Giovanni. O longo século XX. São Paulo: Unesp, 1996.

BARBARA, Danusia. Feijão - aromas e sabores da boa lembrança. São Paulo: Senac, 2005.

BARBOSA, Lívia. "Feijão com arroz e arroz com feijão: o Brasil no prato dos brasileiros". Horizontes Antropológicos, Porto Alegre, ano 13. n. 28, jul/dez 2007.

BASSO, Rafaela. A cultura alimentar paulista: Uma civilização do milho? (16501750). Dissertação de Mestrado. IFCH/Unicamp,2012.

BELASCO, Warren - O que iremos comer amanhã - uma história do futuro da alimentação. São Paulo: Editora Senac São Paulo, 2009.

. "Why food matters". In: Culture \& Agriculture. Vol. 21, n.1, 1999. p. 2734.

BERQUÓ, Elza. "Arranjos familiares no Brasil: uma visão demográfica”. In: NOVAIS, Fernando, História da vida privada no Brasil - contrastes da intimidade contemporânea. São Paulo: Companhia das Letras, 1998. 
BLEIL, Susana Inez - "O Padrão Alimentar Ocidental: considerações sobre mudanças de hábitos no Brasil". In: Cadernos de Debate, Vol. VI, 1998.

BLOCH-DANO, Évelyne. A fabulosa história dos legumes. São Paulo: Estação Liberdade, 2011.

BORÉM, Aluízio \& CARNEIRO, José Eustáquio S. "A cultura". In: In: VIEIRA, Clibas, JUNIOR, Trazilbo \& BORÉM, Aluízio (Ed.). Feijão. Viçosa: EFV, 2006.

BORGES, Jorge Luis. Ficções. São Paulo, Companhia das Letras, 2007.

BRAUDEL, Fernand. Civilização material e Capitalismo. Séculos XV-XVIII. Lisboa: Cosmos, 1970. Tomo I.

. Escritos sobre a história. São Paulo: Perspectiva, 2007

BUENROSTRO, Marco. "El frijol". In: CASTILLO, Gilda (org.). El frijol - un regalo de México al mundo. Ciudad de México: Fundación Herdez, p 4957, 2011.

CAMARGOS, Marcia e SACHETTA, Vladimir. À mesa com Monteiro Lobato. São Paulo: Senac, 2008.

CANDIDO, Antônio. Literatura e Sociedade. Rio de Janeiro: Ouro sobre Azul, 2006.

CANSTATT, Oscar. Brasil, a Terra e a Gente (1868). Rio de Janeiro, Irmãos Pengetti Editores, 1954.

CARNEIRO, Henrique Soares. Comida e sociedade - uma história da alimentação. Rio de Janeiro: Campus, 2003.

. "Comida e Sociedade: significados sociais na história da alimentação". In: Questões \& Debates, Curitiba, n.42, 2005. p. 71-80.

CASTILLO, Gilda (coord.). El Frijol - un regalo de México al mundo. Ciudad de México: Fundaçión Herdez. 2011. 
CASTRO, Josué. Geografia da Fome. Rio de Janeiro: O Cruzeiro, 1946.

. "Fome como força social: fome e paz". In: Fome, um tema proibido. São Paulo: Civilização Brasileira, 2003.

Centro de inteligência do Feijão. Disponível em: http://www.cifeijao.com.br/index.php?p=aspectos botanicos . Acessado em 30/07/2013.

COLLAÇO, Janine Helfst Leicht. "Saberes e Memórias: cozinha italiana e construção identitária em São Paulo". Tese de doutorado, Departamento de Antropologia da Universidade de São Paulo, 2009.

COLLE, Célio Alberto. "A cadeia produtiva do trigo no Brasil: contribuição para a geração de emprego e renda". Dissertação de Mestrado, UFRGS, 1998.

DINIZ, Bernardo Palhares Campolina; SILVEIRA, Fernando Gaiger; BERTASSO, Beatriz Freire; MAGALHÃES, Luis Carlos G; SERVO, Luciana Mendes Santos. "As pesquisas de orçamento familiar brasileiras". In: Fernando Gaiger da Silveira; Luciana Mendes Santos Servo; Tatiane Menezes; Sérgio Franciso Piola. (Org.). Gasto e consumo das famílias brasileiras contemporâneas. Brasília: IPEA, 2007, 17-57.

DORIA, Carlos Alberto. A formação da Culinária Brasileira. São Paulo: Publifolha, 2009.

A culinária materialista. A construção racional do alimento e do prazer gastronômico. São Paulo: Editora Senac São Paulo, 2009.

. "Feijões como patria, locus \& domus no sistema culinário brasileiro". Versão em português de "Beyond Rice Neutrality: Beans as Patria, Locus and Domus in the Brazilian Culinary Sistem", texto publicado originalmente em WILK, Richard e BARBOSA, Livia (orgs), Rice and Beans. A unique dish in a hundred places, NY, Berg, 2012, págs. 121 a 135. 
. Formação da culinária Brasileira. São Paulo: Três Estrelas, 2014.

ELIAS, Norbert. O Processo Civilizador. Rio de Janeiro: Jorge Zahar Editor, 1994. Volume I: Uma História dos Costumes.

ELIAS, Rodrigo. "Breve história da feijoada". In: Nossa História, ano 01. ํㅡ 04, fev de 2004.

FARIA, Luis Caudio de. et. al. "BRS Requinte: nova cultivar de feijoeiro comum, de tipo de grão carioca, com retardamento do escurecimento do grão". Embrapa, 2000.

FEBVRE, Lucien. O problema da incredulidade no Século XVI - a religião de Rabelais. São Paulo: Cia das Letras, 2009.

FELIPPE, Gll. Grãos e sementes - a vida encapsulada. São Paulo: Senac, 2007.

FERRÃO, José E. Mendes. A aventura das plantas e os descobrimentos portugueses. Lisboa: Chaves Ferreira, 2005.

FERREIRA, Carlos Magri; DEL PELOSO, Maria José \& FARIA, Luis Claudio. Feijão na economia nacional. Santo Antônio de Goias: Embrapa Arroz Feijão, 2002.

et.al. "Aspectos econômicos". In: VIEIRA, Clibas, JUNIOR, Trazilbo \& BORÉM, Aluízio (Ed.). Feijão. Viçosa: EFV, 2006.

FISCHLER, Claude. "A 'McDonaldização' dos costumes”. Em: FLADRIN, JeanLouis \& MONTANARI, Massimo (dir.). Historia da Alimentação. São Paulo: Estação Liberdade, 1998.

. \& MASSON, Estelle - Comer: a alimentação dos franceses, outros europeus e americanos. São Paulo: Editora Senac São Paulo, 2010.

- "Gastro-nomie et gastro-anomie: sagesse du corps et crise bioculturelle de l'alimentation moderne", em Communications, n 31, 1979. 
FLANDRIN, Jean-Louis \& MONTANARI, Massimo (dir.) - História da Alimentação. São Paulo: Estação Liberdade, 1998.

FONTENELLE, Esleide - O nome da marca - Mc Donald's, fetichismo e cultura descartável. São Paulo: Boitempo, 2006.

FRIEIRO, Eduardo. Feijão, Angu e Couve. São Paulo: Ed. Universidade de São Paulo, 1982.

FUNDAÇÃO Getúlio Vargas. "A campanha geográfica". O Observador Econômico e financeiro. Rio de Janeiro, p 129-135. abr/jun 1940. p 129.

GEARY, Patrick J. O mito das nações: a invenção do nacionalismo. São Paulo: Conrad Editora do Brasil, 2005.

GONZAGUINHA, O preto que satisfaz. In: FRENÉTICAS, Caia na Gandáia, Rio de Janeiro: Warner 1978.

HAMBURGER, Esther. "Diluindo fronteiras: a televisão e as novelas no cotidiano". In: NOVAIS, Fernando, História da vida privada no Brasil contrastes da intimidade contemporânea. São Paulo: Companhia das Letras, 1998.

HARVEY, David. The Condition of Postmodernity: na Enquiry into the Origins of Cultural Change. Oxford: Blackwell Publishers, 1990.

HOBSBAWM, Eric J. Nações e Nacionalismos desde 1780. Rio de Janeiro: Paz e Terra, 1990.

- Era dos extremos - o breve século XX (1914-1991). São Paulo: Companhia das Letras, 1995.

. \& RANGER, Terence. A invenção das tradições. Rio de Janeiro: Paz e Terra, 2008. . Sobre História. São Paulo: Companhia das Letras, 1998. 
HOFFMANN, Rodolfo. "Elasticidade-renda das despesas com alimentos em regiões metropolitanas do Brasil em 1995-86. Informações Econômicas, v30, n.2, p. 17-24, fev. 2000.

HOUAISS, Antonio e VILLAR, Mauro de Salles. Dicionário Houaiss de Língua Portuguesa. Rio de Janeiro: Objetiva, 2001.

JONES, A. L. Phaseolus Bean: Post-harvest Operation. Centro Internacional de Agricultura Tropical, FAO. 1999.

KOSELLECK, Reinhart. Futuro Passado - contribuição à semântica dos tempos históricos. Rio de Janeiro: Contraponto, 2006.

LABROUSSE, Ernest. Esquisse du mouvement de prix et de revenus en France au XVIII siècle. Paris: Librarie Dalloz, 1933.

- La crise de l'économie française à la fin d'Ancient Régime et au début de la Revolution. Paris: PUF, 1944.

LEVI-STRAUSS, Claude (org.). La identidad. Madrid: Ediciones Petrel, 1981.

MALAVOTA, Leandro; SANTANA, Luciana e MONTEIRO, Pedro. "Um retrato que o Brasil desconhece: a documentação do ENDEF como fonte de informações para o historiador" XVII Simpósio Nacional de História. Natal, 2013.

MELLO, João Manuel Cardoso de \& NOVAIS, Fernando. "Capitalismo tardio e sociabilidade moderna". In: NOVAIS, Fernando (org.), História da vida privada no Brasil - contrastes da intimidade contemporânea. Vol 04. São Paulo: Companhia das Letras, 1998.

MENESES, Ulpiano T. Bezerra \& CARNEIRO, Henrique - "A História da alimentação: balizas historiográficas" In: Anais do Museu Paulista: História e Cultura Material. Nova Série, Vol. 5., jan/dez 1997, p. 9-92

MINTZ, Sidney. Tasting food, tasting freedom: excursions into eating, culture, and the past. Boston, 1996. 
MONTANARI, Massimo. Comida como cultura. São Paulo: Senac, 2008.

MONTEIRO, Carlos Augusto. "Feijão, comida rápida e obesidade". Folha de São Paulo. 13 de junho de 2010, Primeiro Caderno, A3. Disponível em: http://acervo.folha.com.br/fsp/2010/6/13/2

MORAES, Marcos Antonio de (org.). Câmara Cascudo e Mário de Andrade: cartas, 1924-1944. São Paulo: Global, 2010.

OLIVEIRA, Débora Santos de S. - A Transmissão do Conhecimento Culinário no Brasil Urbano do Século XX. Dissertação de Mestrado. FFLCH-USP, São Paulo, 2010.

OLIVEIRA, Jane Souto, "Brasil mostra a tua cara": imagens da população brasileira nos censos demográficos de 1872 a 2000. Escola Nacional de Ciências Estatísticas, texto para discussão 06. Rio de Janeiro, 2003.

PAPAVERO, Claude. "Dos feijões à feijoada: a transformação de um gênero comestível pouco apreciado em mantimento básico brasileiro". Trabalho apresentado na 26ํㅡㄹ Reunião Brasileira de Antropologia realizada entre os dias 01 e 04 de junho de 2008 em Porto Seguro, Brasil.

PASSIANI, Enio. Na trilha do Jeca, Monteiro Lobato e a formação do campo literário no Brasil. Bauru: EDUSC, 2003.

PENHA, Eli Alves. A criacao do IBGE no contexto da centralizacao politica do Estado Novo. Memoria Institcional - 4, IBGE. Rio de Janeiro, 1993.

PINTO, Julio Pimentel. Memória do mundo - ficção, memória e historia em Jorge Luis Borges. São Paulo: Estação Liberdade, 1998.

POLLAN, Michael. O Dilema do Onívoro, uma história natural de quatro refeições. Rio de Janeiro, Intrínseca, 2007.

RENAN, Ernest (1991) 'What is a Nation?', (aula dada em Paris, 1882). 
RODRIGUES, Jaime. Alimentação, vida material e privacidade. Uma história social de trabalhadores em São Paulo nas décadas de 1920-1960. São Paulo: Alameda, 2011.

ROSSI, Paolo. Comer: necessidade, desejo, obsessão. São Paulo: Editora Unesp, 2004.

RUBINSTEIN, Licia. "'O censo vai contar para você': design gráfico e propaganda política no Estado Novo". Dissertação de Mestrado. PUC Rio, Rio de janeiro, 2007.

SAHLINS, Marshall. Cultura e Razão Prática. Rio de Janeiro: Jorge Zahar Editora, 2003.

SALVADOR, Carlos Alberto. "Análise da conjuntura agropecuária, safra 2011/2012 - feijão". Estado do Paraná - Secretaria da Agricultura e do Abastecimento, Departamento de Economia Rural.

SANTANA, Francisco. Saco de Feijão. In: CARVALHO, Beth. Firme e forte no pagode. Rio de Janeiro: Sony, 2004.

SANTOS, João Bosco dos \& GAVILANES, Manuel Losada. "Botânica". In: VIEIRA, Clibas, JUNIOR, Trazilbo \& BORÉM, Aluízio (Ed.). Feijão. Viçosa: EFV, 2006.

SARLO, Beatriz. Tempo Passado - cultura da memória e guinada subjetiva. São Paulo, Companhia das Letras, 2007.

SCHWARCZ, Lilia Katri Moritz. "Complexo de Zé Carioca. Notas sobre uma identidade mestiça e malandra". In: Revista Brasileira de Ciências Sociais, n. 29, 1995, p 43-69.

SENRA, Nelson de Castro. História das estatísticas brasileiras, v.4: estatísticas formalizadas (1972-2002). Rio de Janeiro: IBGE, 2009a. . Uma breve história das estatísticas brasileiras (1822-2002). Rio de Janeiro: IBGE/CDDI, 2009b. 
SILVA, João Luiz Máximo da. O impacto do gás e da eletricidade na casa paulistana (1870-1930). Dissertação de mestrado. Departamento de História, FFLCH/USP, 2002.

SILVA, Paula Pinto e. Farinha, feijão e carne-seca: um tripé culinário no Brasil colonial. São Paulo: Senac São Paulo, 2005.

STEINGARTEN, Jeffrey. O homem que comeu de tudo. São Paulo: Companhia das Letras, 2000. p. 66.

TAYLOR, Charles. Multiculturalisme. Différence et démocratie. Paris: Flammarion, 1994.

TILLY, Charles. Big Structures, Large Processes, Huge Comparisons. Nova York: Hussel Sarge. 1984

WOORTMANN, Klass. "Hábitos e Ideologias alimentares em grupos sociais de baixa renda". Relatório Final. Série Antropologia, v.20, Universidade de Brasília, 1978.

VASCONCELLOS, Maurício Teixeira Leite de. Os principais tipos alimentares do Brasil. Divisão de Políticas Alimentares e de Nutrição, FAO, 1987. 